$$
\begin{gathered}
\text { UNIVERSIDADE DE SÃO PAULO } \\
\text { FACULDADE DE FILOSOFIA, LETRAS E CIÊNCIAS HUMANAS } \\
\text { DEPARTAMENTO DE ANTROPOLOGIA } \\
\text { PROGRAMA DE PÓS-GRADUAÇÃO EM ANTROPOLOGIA SOCIAL }
\end{gathered}
$$

RENAN PATRICK PINAS ARNAULT

Altamira indígena em Belo Monte: experiências Xipaya e Kuruaya em transformação

(Versão corrigida)

São Paulo 


\author{
UNIVERSIDADE DE SÃO PAULO \\ FACULDADE DE FILOSOFIA, LETRAS E CIÊNCIAS HUMANAS \\ DEPARTAMENTO DE ANTROPOLOGIA \\ PROGRAMA DE PÓS-GRADUAÇÃO EM ANTROPOLOGIA SOCIAL
}

\title{
Altamira indígena em Belo Monte: experiências Xipaya e Kuruaya em transformação
}

(Versão corrigida)

Renan Patrick Pinas Arnault

Dissertação apresentada ao Programa de PósGraduação em Antropologia Social do Departamento de Antropologia da Faculdade de Filosofia, Letras e Ciências Humanas da Universidade de São Paulo, para a obtenção do título de Mestre em Antropologia Social.

Orientador: Prof. Dr. Renato Sztutman

São Paulo

2016 
ARNAULT, Renan Patrick Pinas. Altamira indígena em Belo Monte: experiências Xipaya e Kuruaya em transformação. Dissertação apresentada à Faculdade de Filosofia, Letras e Ciências Humanas da Universidade de São Paulo como pré-requisito para obtenção do título de Mestre em Antropologia Social (Antropologia Social)

Aprovado em:

1

Banca Examinadora

Profa Dra Marta Rosa Amoroso PPGAS/USP

Profa Dra Regina Aparecida Polo Müller IAR/UNICAMP

Prof. Dr. Renato Sztutman PPGAS/USP 
Às matriarcas Xipaya e Kuruaya por seu exemplo de resistência. 


\section{AGRADECIMENTOS}

Inicio meus agradecimentos estendendo a dedicatória como forma de homenagem às muitas matriarcas indígenas de Altamira, as que se foram e as que ainda mantêm-se firmes criando seus filhos e netos, com perseverança e alegria de mulheres guerreiras que aprendi a admirar e me ensinaram muito durante esses anos de pesquisa e vivência inimaginável como: Maria Augusta Xipaya "Xipainha", sua irmã Ana Kurica, Maria Kuruaya, Nazaré Xipaya, Maria Yawaidu, Terezinha Xipaya, Miriã Xipaya e outras tantas novas guerreiras como Francinélia Xipaya, Raimunda Kuruaya, Josa Kuruaya, Liliane Alves Xipaya, Marilene Carvalho Xipaya e Socorro Arara.

Faço homenagem aos anciões que me inspiraram com suas histórias de coragem e com a serenidade em contá-las como José Mineiro "Caneco” Kayapó, José Marialves Xipaya, Firmino Kuruaya e Otávio Juruna. Também agradeço a liderança Gilson Kuruaya, pelo seu fundamental apoio na pesquisa e pela amizade. Agradeço também à contribuição do migrante cearense e lutador Chico Tatu e toda sua família.

Quero indicar também minha admiração pelas guerreiras Juruna as quais não pude prestar minha homenagem durante a dissertação, mas com quem convivi e aprendi muito como: Iracilda Juruna, Evódia Juruna, Iranilde Juruna, Sabrina Juruna e especialmente Irazilda Juruna, liderança exemplar com quem tive a alegria de contribuir na construção da Associação Tubyá. Deixo também minha consideração pelas importantes matriarcas Juruna, Ester e Miúda.

Expresso minhas admirações e agradecimentos à Elza Xipaya, que contribuiu enormemente com minha pesquisa, e que acima de tudo, é um exemplo de guerreira, talvez incomparável, que lutou uma vida pela causa indígena citadina e mantém-se no front de Altamira.

À liderança Claudio Kuruaya, pessoa de fibra e ideais que, percorrendo toda a cidade de Altamira de bicicleta, foi um guia para a conquista do Pedral, uma esperança para muitos indígenas citadinos de Altamira. Tem minha gratidão e profundo respeito.

Ao meu grande amigo e incentivador Paulo Serpa que me ensinou muito sobre ética e responsabilidade do trabalho do antropólogo, quero demonstrar minha admiração por sua exemplar trajetória como antropólogo e agradecer todo apoio dado nos trabalhos de campo e nas discussões teóricas que foram fundamentais para minhas escolhas. 
À Mayra Pascuet e Mariana Favero pela ajuda fundamental com as informações sobre as famílias indígenas realocadas, quero também manifestar o respeito e admiração pelo sacrificante trabalho que fizeram entregando-se de corpo e alma. Sou muito contente pela profunda amizade que construímos durante nossas cervejas em Altamira.

Ao amigos que fiz em Altamira, Lucas Campostrini e Chrystiano Alves da Costa, serei eternamente grato pelo acolhimento e por estarem sempre dispostos a ajudar.

Aos meus velhos parceiros de campo e muitas outras aventuras, Helder Pomaro e Matheus Zati, agradeço pelas fotografias de qualidade e pelo companheirismo inabalável. Tenham certeza de que contribuíram muito para esse projeto.

Às amigas Patrícia Andrade, Nefertiti Hass e Renata Utsunomyia que fiz durante os trabalhos em Altamira, ajudando na formação de associações e bebendo caxiri, agradeço pela possibilidade de construir com vocês esse trabalho indigenista que irá me marcar para sempre.

À professora Regina Müller, que me ofereceu oportunidade tão incrível de participar do trabalho em Altamira, agradeço por aceitar o convite para qualificação e defesa e expresso grande admiração pela contribuição para a antropologia que vim a conhecer e respeitar.

À professora Marta Amoroso que gentilmente aceitou o convite para a arguição, agradeço o estímulo intelectual e as valiosas orientações que iluminaram a dissertação.

Ao PPGAS com todas suas pessoas, especialmente aos professores que me ajudaram muito em suas aulas e debates.

Aos meus amigos do mestrado 2013, que tornaram esse processo de formação mais alegre e despretensioso, muitas das nossas conversas e discussões foram de grande valia.

À importantíssima orientação do professor Renato Sztutman, agradeço as leituras aguçadas e as indicações imprescindíveis para a qualidade de pesquisa. Agradeço a sempre elegante paciência com os atrasos e inabalável confiança na pesquisa.

Aos meus amigos de quase-infância, Carlos Ranea e Arnaldo Janiak com quem dividi algumas angústias dessa empreitada e acima de tudo reflexões brilhantes. Agradeço imensamente pelo abstract e pela leitura minuciosa.

Ao meu primo-irmão mais velho Raoni Rossi, admirador e entusiasta das culturas indígenas, esse trabalho faz parte dos sonhos que dividimos desde a infância. 
Aos meus pais, Patrick Arnault e Marlene Pinas, que foram responsáveis pelo ambiente estimulante que levou às escolhas que faço hoje, sem o amor de vocês eu não estaria aqui.

Ao meu irmão Victor Arnault, quero dividir essa conquista e agradecer a amizade incondicional de seu amor fraternal que me inspira tanto.

Finalmente expresso a importância de minha companheira e amiga Ana Paula Rocha para a realização desse projeto de vida. Sem seu incentivo, apoio e ajuda tudo isso seria menos prazeroso. Obrigado por compartilhar minhas angústias, seu amor é minha melhor inspiração. 


\title{
RESUMO
}

A dissertação propõe um recorte etnográfico para pensar a situação dos indígenas moradores da cidade de Altamira-PA face à construção da hidrelétrica de Belo Monte. Acompanhando de perto algumas experiências dos habitantes Xipaya e Kuruaya da cidade (grupos do tronco linguístico Tupi), a etnografia lança mão de três contribuições diferentes da antropologia para pensar memória, parentesco e política entre os interlocutores. Partindo do espaço geográfico e simbólico dos tradicionais bairros Xipaya e Kuruaya de Altamira (Muquiço/São Sebastião e Jardim Independente/Missão), os dados estatísticos e relatos reconstituem as migrações e transformações experienciadas, falam de características da espacialização e vivência na cidade e na extensão do médio rio Xingu. Diferentes práticas e discursos nativos são produto de relações de parentesco e corresidência entre indígenas e não indígenas da região, que expressam estilos de bem viver e, por sua vez, também estruturam propostas e atuações do movimento indígena citadino. Tendo em vista o cenário crítico imposto pela construção de Belo Monte com suas transformações inerentes, a etnografia buscou restituir agências Xipaya e Kuruaya que tencionam uma vida melhor.

Palavras-chave: Xipaya, Kuruaya, memória, parentesco, indígenas na cidade de Altamira, movimento indígena citadino, associação indígena, hidrelétrica de Belo Monte.

\begin{abstract}
This essay proposes an ethnographic approach as a means to think about the situation of the indigenous people residing in Altamira-PA under the construction of the hydroelectric plant of Belo Monte. By closely witnessing a certain number of happenings of the Xipaya and Kuruaya townspeople (groups of the Tupian language family), this ethnography provides three different anthropological contributions to think about memory, kinship and politics between the counterparts. Starting with the fields, both geographic and symbolic of the traditional Xipaya and Kuruaya boroughs of Altamira (Muquiço/São Sebastião e Jardim Independente/Missão), statistical data and narrative registers retrace migrations and experienced transformations, thus speaking about the recreation of the space and about the perception of life, both in the city and throughout the extensions of the Medium Xingu River. Diverse techniques and native discourses are a product of kinship relations and cohabitation between indigenous and non-indigenous inhabitants, who express styles of well-living and, in
\end{abstract}


turn, also structure bidding and fields of action for the urbanite indigenous movement. Keeping in sights the critical scenario imposed by the construction of the Belo Monte plant, as well as its underlying transformations, the ethnography seeked to reinstate Xipaya and Kuruaya agencies that intend to a better life.

Keywords: Xipaya, Kuruaya, memory, kinship, indigenous in the city of Altamira, urbanite indigenous movement, indigenous association, hydroelectric plant of Belo Monte.

\section{RÉSUMÉ}

La thèse propose un découpage ethnographique pour réfléchir à la situation des Indigènes qui habitent à Altamira-PA. Cette réflexion se fait en vertu de la construction, du barrage de Belo Monte. L'ethnographie fait usage de trois contributions différentes de l'anthropologie pour réfléchir à la mémoire, à la parenté et à la politique entre les interlocuteurs. Elle suit de près quelques expériences des habitants Xipaya et Kuruaya de la ville (groupes du tronc linguistique Tupi). Les données et les rapports statistiques reconstituent la migration et les transformations expérimentées et parlent de caractéristiques spatiales et de vivre dans la ville et au long du moyen Rio Xingu. Elles se basent sur l'espace géographique et symbolique des quartiers traditionnels Xipaya et Kuruaya d'Altamira (Muquiço/São Sebastião et Jardim Independente/Missão). Les pratiques différentes ainsi que les discours natifs sont le produit des rapports de parenté et de cohabitation entre autochtones et non-autochtones de la région; elles expriment les styles de bien-vivre, et à leur tour, suggèrent des structures et les activités du mouvement indigène de la ville. Étant donné que le scénario critique imposé par la construction de Belo Monte, avec ses transformations inhérentes, l'ethnographie a cherché à restituer les agences Xipaya et Kuruaya, qui se proposent de construire une vie meilleure.

Mots-clés: Xipaya, Kuruaya, de la mémoire, de la parenté, des autochtones dans la ville d'Altamira, la ville mouvement indigène, association indigène, barrage de Belo Monte. 


\section{LISTA DE FIGURAS}

Figura 1"Mapa Etno-histórico do Brasil e regiões adjacentes" adaptado de Nimuendaju (1944) - Fonte: FIBGE

Figura 2 - Mapa do município de Altamira-PA contendo as delimitações de terras indígenas.

Figura 3 - Etnia dos representantes indígenas. Fonte: Relatório final de Cadastro das Famílias

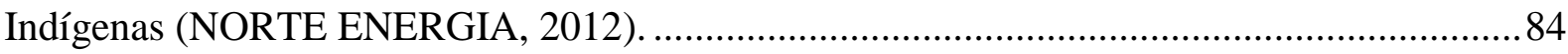

Figura 4 - Sede de Altamira - PA. Fonte: Simoni \& Dagnoni (2012), ................................... 85

Figura 5 - Vista aérea da região do bairro do Muquiço (São Sebastião) e Jardim Independente

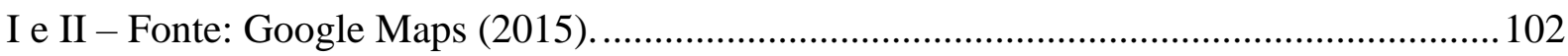

Figura 6 - Rua no bairro Muquiço (São Sebastião) - janeiro de 2012 ................................... 103

Figura 7 - Rua no bairro Muquiço (São Sebastião) - janeiro de 2012 .................................. 103

Figura 8 - Palafitas à beira do rio Xingu no bairro Muquiço (São Sebastião) - janeiro de 2012.

Figura 9 - Palafitas à beira do rio Xingu no bairro Muquiço (São Sebastião) - janeiro de 2012.

Figura 10 - Rua no bairro Muquiço (São Sebastião) - janeiro de 2012 . ..................................105

Figura 11 - Rua no bairro Muquiço (São Sebastião) - março de 2015 .................................. 105

Figura 12 - Rua no bairro Muquiço (São Sebastião) - março de 2015 ................................. 106

Figura 13 - Identificação de moradia afetada pela construção do reservatório de Belo Monte no bairro do Muquiço (São Sebastião) - março de 2015 . .................................................... 106 Figura 14 - Rua Cel. José Porfírio (via principal) no bairro Jardim Independente II - março de 2015. 108

Figura 15 - Hotel na Rua Cel. José Porfírio (via principal) no bairro Jardim Independente II -

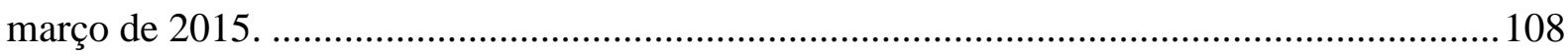

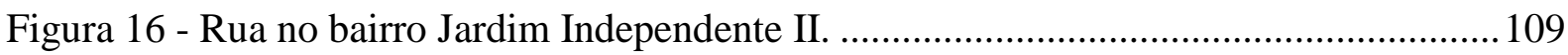

Figura 17 - Rua no bairro Jardim Independente II - março de 2015 .................................... 110

Figura 18 - Rua no bairro Jardim Independente II - março de 2015 .....................................110

Figura 19 - Palafitas no bairro Jardim Independente II - maio de 2015 . .............................. 111

Figura 20 - Palafitas no bairro Jardim Independente II - maio de 2015 . ............................. 111

Figura 21 - Início das realocações de moradias por conta do reservatório de Belo Monte no bairro Jardim Independente II - março 2015.

Figura 22 - Renda familiar. Fonte: Relatório final de Cadastro das Famílias Indígenas (NORTE ENERGIA, 2011).

Figura 23 - Ocupação dos chefes de família. Fonte: Relatório final de Cadastro das Famílias Indígenas (NORTE ENERGIA, 2011).

Figura 24 - Objetivo da pesca. Fonte: Relatório final de Cadastro das Famílias Indígenas (NORTE ENERGIA, 2011).

Figura 25 - Casamentos Interétnicos 1. Fonte: EIA/RIMA Componente Indígena Citadino, 2009.

Figura 26 - Casamentos Interéticos 2. Fonte: Relatório final de Cadastro das Famílias Indígenas (NORTE ENERGIA, 2011).....

Figura 27 - Genealogia Kirinapãe e Payá. 
Figura 28 - Da esquerda para direita, Xipainha e Ana Kurica, matriarcas Kuruaya - 2015...139

Figura 29 - Raimunda e Firmino Kuruaya, filhos da matriarca Tereza Kuruaya - 2014........ 143

Figura 30 - Genealogia Akarirá, Painaré e Aricafu. .......................................................... 144

Figura 31 - Tereza Xipaya, matriarca filha do famoso Aricafu Kuruaya, e seu marido Antônio

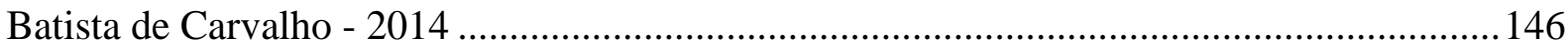

Figura 32 - Genealogia de Manuel Bitatá Cojubim, Ducaré e Uawmã. ...............................149

Figura 33 - Área definida para a construção do novo assentamento das famílias indígenas e

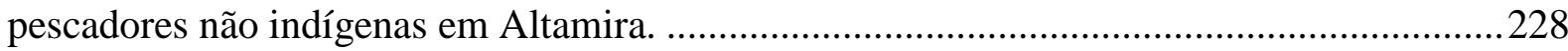

Figura 34 - Casa destruída no bairro São Sebastião (Muquiço) - Altamira, julho de 2015...230

Figura 35 - Mudança de material construtivo aproveitável - bairro São Sebastião (Muquiço) -

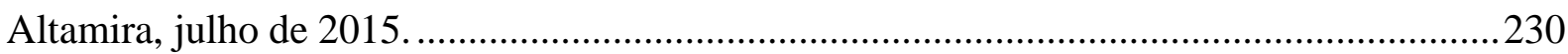

Figura 36 - Bairro São Sebastião (Muquiço) - Altamira, julho de 2015. ..............................231

Figura 37 - Av. Cel. José Porfírio no bairro Jd. Independente II (Missão) - Altamira, julho de

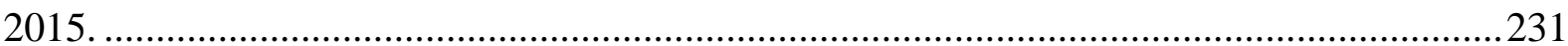

Figura 38 - Os Xipaya e Kuruaya de Altamira durante a Oficina de Saberes e Fazeres -

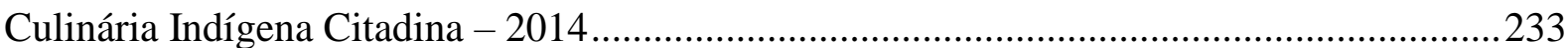

\section{LISTA DE TABELAS}

Tabela 1 - Proporção das etnias da população indígena urbana de Altamira - PA.................. 81

Tabela 2 - Levantamentos da população indígena na cidade de Altamira, PA. ........................83

Tabela 3 - Evolução da proporção das etnias sobre a população indígena total na cidade de

Altamira.

Tabela 4 - Distribuição da população indígena pelos bairros da cidade de Altamira. .86

Tabela 5 - Distribuição das famílias indígenas nos setores da cidade de Altamira por etnia...90

Tabela 6 - Proporção das etnias sobre o total de famílias indígenas residentes nos setores de

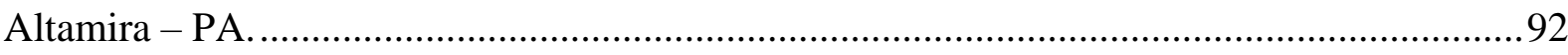

Tabela 7 - Quadro de associações citadinas e ribeirinhas em Altamira ................................207 


\section{SUMÁRIO}

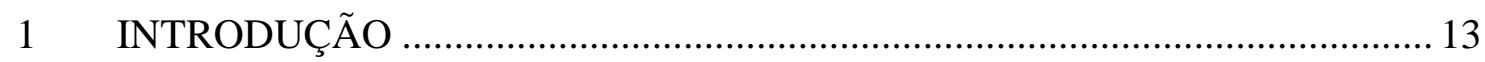

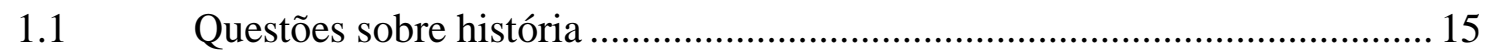

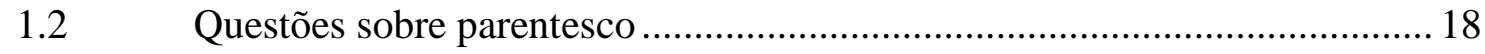

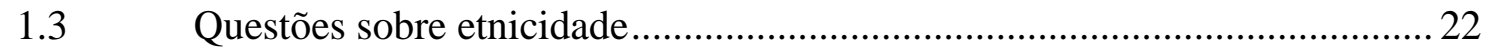

Questões sobre movimento indígena .................................................. 25

2 DO ALTO À MISSÃO: HISTÓRIAS INDÍGENAS EM ALTAMIRA-PA....... 28

2.1 Relatos e documentos: apontamentos para uma abordagem etnográfica das histórias indígenas 28

2.2 Missão Tavaquara: análise de um documento histórico sobre Altamira ...... 33

2.3 Muquiço e Missão: histórias dos bairros indígenas em Altamira .................. 40

2.4 "Lá no alto” - histórias Xipaya e Kuruaya nos rios Iriri e Curuá.................. 53

2.5 Conclusões: contribuições do debate entre antropologia e história para uma etnografia dos indígenas da cidade de Altamira.

3 ENTRE PARENTES: ETNOGRAFIA DAS FAMÍLIAS INDÍGENAS DE ALTAMIRAPA 78

3.1 População indígena da cidade de Altamira - diálogos com as pesquisas quantitativas 78

3.2 Os indígenas na cidade Altamira: deslocamentos e transformações .95

3.2.1 Ocupações: fragmentos sobre vivências indígenas em Altamira 114

3.3 Casamentos 129

3.3.1 Genealogias indígenas de Altamira................................................................ 137

3.3.2 Genealogias Xipaya - Kuruaya …………..................................................... 141

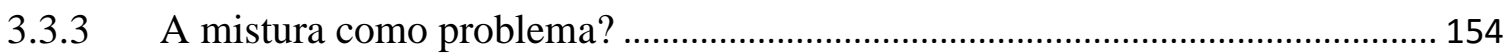

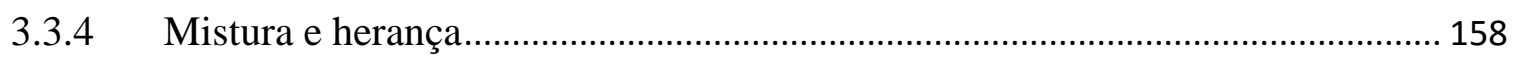

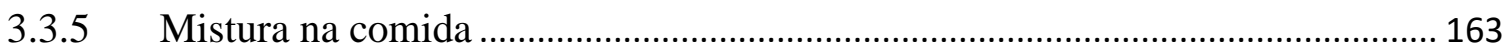

3.3.6 Casamento é mistura? Sentidos do casamento indígena-não indígena................ 173 
4 A POLÍTICA INDÍGENA NA CIDADA DE ALTAMIRA: DESAFIOS ANTES E

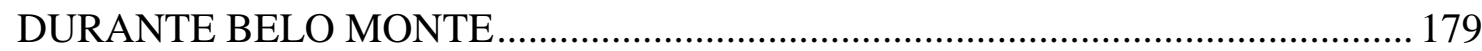

4.1 Movimento indígena citadino e os projetos hidrelétricos .......................... 179

4.2 Primeiros passos do movimento indígena citadino................................... 187

4.3 Os Xipaya e os Kuruaya: reconhecimento étnico e as Terras Indígenas .... 191

4.4 As matriarcas e o movimento de mulheres ................................................ 192

4.5 O cadastro dos indígenas de Altamira e o movimento indígena citadino... 196

F.6 Fortalecimento cultural e o movimento indígena .................................. 202

4.7 Belo Monte e o novo movimento indígena citadino ................................ 207

4.8 Quem quer ser índio depois de Belo Monte?.......................................... 212

4.9 Bairro indígena: os desafios da renovação movimento indígena citadino.. 217

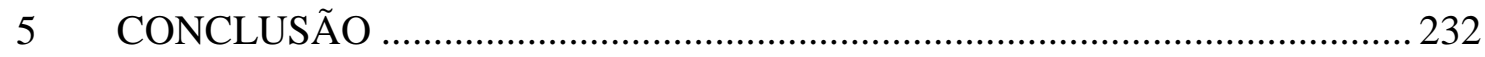




\section{INTRODUÇÃO}

O presente estudo propôs construir um recorte etnográfico para pensar aspectos gerais da presença indígena na cidade de Altamira-PA e especificamente dos grupos Xipaya e Kuruaya (povos do tronco linguístico Tupi). Levando em conta as especificidades da condição dos grupos indígenas residentes nesse espaço urbano, e o contexto por que passa a região, em que a construção da usina hidrelétrica de Belo Monte impõe transformações incontornáveis, a etnografia visou a construção de um quadro de análise dessa conjuntura por meio das reflexões propostas por seus interlocutores. Esse desenho de estudo teve como objetivo permitir à pesquisa problematizar alguns aspectos fundamentais da vida social dessas populações. Para tanto, foram eleitos, como ponto de partida, os bairros considerados como tradicionalmente ocupados pelos indígenas Xipaya e Kuruaya, haja vista que são os principais grupos a residirem em toda cidade de Altamira e a atuarem nas questões indígenas da cidade. A escolha dos bairros pela etnografia passa pela reconstituição da importância história local, remetendo-se à condição de serem os possíveis locais onde fundou-se a primeira ocupação que daria origem a cidade, conhecida como Missão Tavaquara, um aldeamento principalmente dos Juruna da região iniciado pelos jesuítas por volta do ano de 1750 . Lançando mão das memórias históricas dos interlocutores para explorar a sobreposição de significados da experiência indígena urbana, a etnografia também foi impelida a acompanhar a iminente situação de alagamento parcial dos bairros referidos, por conta da construção do reservatório da usina de Belo Monte, fato que consumiu as preocupações e angústias dos habitantes indígenas, e reconfigurou as prioridades do movimento indígena local.

Em seu primeiro momento a pesquisa deslocou-se sobre os processos de constituição histórica dos bairros São Sebastião e Jardim Independente (ainda hoje lembrados pelos nomes de Muquiço e Missão, respectivamente), com ênfase na contribuição dos grupos indígenas que ali residiram e residem, principalmente os grupos Xipaya e Kuruaya. Esse olhar é construído através do cruzamento entre memórias históricas e relatos de trajetórias de vida de seus moradores e de fontes bibliográficas que documentam a história da região.

Uma vez posto esse panorama histórico foi possível à etnografia explorar alguns aspectos das condições contemporâneas em que vivem indígenas na cidade de Altamira, tendo em vista 
os modos como os interlocutores manejam continuidades e mudanças de sua organização sociocultural. A reflexão sobre aspectos da condição indígena urbana remeteu a pesquisa à exploração do material estatístico produzido sobre essas populações - grande parte dele ligado à presença de Belo Monte - tratando diretamente dos interlocutores da pesquisa alvos do processo de realocação urbana deflagrado pela construção da usina. Situados histórica e etnograficamente, esses dados permitiram lançar luz sobre os modos da espacialização indígena na cidade, permitindo atribuir as especificidades ao macro fenômeno da habitação indígena de Altamira.

Em seguida, ao arcabouço histórico e sociológico problematizado pela etnografia somouse o esforço de perseguir as práticas e discursos capazes de caracterizar experiências Xipaya e Kuruaya na cidade. Para tanto, a investigação debruçou-se sobre as afirmações e ações dos interlocutores que reiteravam a importância dos valores da família e da vizinhança. A sugestão ao problema de pesquisa integrou a discussão sobre memória e história. Falando de alianças e do contado com os não indígenas, a etnografia pôde perscrutar os sentidos Xipaya e Kuruaya sobre origem, mistura e pertencimento. Tais noções nativas permitiram a problematização da produção política entre os interlocutores da pesquisa, tendo como vetor a formação das lideranças e associações indígenas da cidade. Desse complexo a dissertação foi capaz de trazer questões sobre as consequências dos impactos de Belo Monte para os interlocutores da pesquisa, pensadas a partir da militância política do movimento indígena citadino. Por meio de diferentes práticas e discursos dos moradores indígenas de Altamira, a dissertação pretendeu restituir pontos de vista sobre os processos de ocupação, urbanização e transformação social nessa cidade amazônica.

As questões que permearam a etnografia dialogam com uma ampla bibliografia antropológica que transcende os limites da etnologia indígena, trazendo contribuições da antropologia urbana (Andrade, 2012), e da teoria etnográfica dos sentidos do político (Goldman, 2006). É preciso alertar que o presente recorte teórico-etnográfico alinha-se menos à tentativa de dar cabo a todos os problemas levantados, e mais a ideia da urgência determinada pelos problemas trazidos pela presença de Belo Monte na região de Altamira. Se o contexto Belo Monte foi decisivo para as escolhas analíticas propostas pela etnografia, as formas como essas implicações do empreendimento foram abordadas decorrem do lugar específico que os grupos indígenas da cidade, principalmente os Xipaya e Kuruaya, interpretam e avaliam essas influências. Precavendo-se contra a inclinação de tomar o problema de Belo Monte como primordial para o estudo e para os interlocutores (embora ele 
seja nos muitos momentos em que o empreendimento afetou incontornavelmente a vida das pessoas, como nos processos realocações urbana, por exemplo) a abordagem etnográfica preocupou-se em demonstrar a equivalência dos problemas propostos, interligando cada dimensão analítica como um modo de apresentar a complexidade das experiências oferecidas pelos interlocutores da pesquisa. Por sua vez cada camada analítica é devedora das muitas e diversificadas experiências compartilhadas entre o pesquisador e os interlocutores, desde o primeiro contato, ainda no ano de 2010, a partir do trabalho de levantamento sobre o patrimônio histórico e cultural regional - que tangenciava a questão indígena na cidade -, passando pelas contribuições da pesquisa de campo do mestrado até chegar no trabalho indigenista desenvolvido principalmente junto aos representantes das associações e lideranças indígenas citadinas no contexto das contrapartidas de Belo Monte, finalizado em meados de 2015. Cada operação reflexiva proposta condiz com esses espaços de implicação da experiência etnográfica entre os indígenas e o antropólogo que constroem diálogos sobre história, parentesco e política. Esse movimento consistiu, então, na tentativa de atingir uma densidade descritiva, que também é interpretativa, sobre a cadeia de significados e proposições oferecidas por alguns Xipaya e Kuruaya de Altamira.

Sem dar conta de todas as interfaces possíveis com as contribuições dos estudos antropológicos, a dissertação foi inspirada por determinados trabalhos que orientaram seu olhar etnográfico. A seguir são apresentados os grandes temas que apoiaram a descrição etnográfica (como também os que foram abandonados), servindo de introdução para a leitura de cada capítulo que trará a exploração das temáticas.

\subsection{Questões sobre história}

A perspectiva histórica aventada pela dissertação retomou as perguntas delineadas durante o primeiro contato do pesquisador com a região de Altamira, anterior ao ingresso no mestrado do PPGAS-USP no ano de 2013. Entre os anos de 2010 e 2012 frequentei a região de Altamira, visitando tanto os municípios que estão diretamente ligados à construção da Rodovia Transamazônica, como Anapu, Brasil Novo e Medicilândia, como aqueles outros de origem mais antiga, cuja principal ligação ainda se dá por meio do rio Xingu, como Senador 
José Porfírio, Porto de Moz e Gurupá ${ }^{1}$. A visita a todos esses municípios foi possível porque foram avaliados como pertencendo às áreas de influência da hidrelétrica de Belo Monte. Minha experiência na região foi, portanto, com trabalho dentro do Plano Básico Ambiental (PBA) da usina de Belo Monte, precisamente, como havia e vem sendo divulgado nos meios de comunicação e outros, trabalho de implementação das contrapartidas diante dos impactos socioambientais que viriam com a construção da obra: uma série de ações que se somam às famigeradas condicionantes. Meu papel nesse processo limitava-se à atuação profissional dentro do Programa de Resgate e Valorização do Patrimônio Histórico e Cultural das áreas de influência do empreendimento, de forma a criar documentos sobre história e cultura a serem depositados em Casas de Memória regionais².

A importância de retomar essa etapa, anterior ao presente estudo, não se refere apenas ao primeiro contato com a região, mas trata das influências que despertaram interesses e perspectivas que fundamentaram a elaboração do projeto de pesquisa. Toda imersão que o trabalho exigia instigou muitas das propostas da presente pesquisa, seja por conta do levantamento de informações históricas, econômicas e políticas sobre a região, pela reflexão suscitada pela necessidade de construção de métodos e ferramentas de pesquisa para identificação dos patrimônios, ou pela discussão sobre as finalidades e possibilidades desse tipo de pesquisa, sem contar a fundamental experiência de campo proporcionada. Por sua vez, a intenção foi também aprofundar as questões que apareciam durante esse trabalho, mas que não encontravam espaço para serem desenvolvidas nesse tipo de pesquisa. Destaca-se que o tema desta pesquisa de mestrado, que trata da presença indígena em Altamira, não estava oficialmente abarcado pelo projeto de trabalho do PBA do qual participava, pois a "parte indígena" do projeto não era de responsabilidade da empresa em que eu estava empregado. Assim, meu interesse pelo fenômeno da presença indígena na cidade de Altamira

\footnotetext{
${ }^{1}$ É interessante notar que essa caracterização das cidades a partir da influência do meio de acesso parte da forma como ocorreram as dinâmicas de ocupação desses municípios. Através das frentes de desenvolvimento de atividades econômicas na Amazônia, implantadas a partir de grandes eixos de proteção do território e integração nacional desenvolvidos pelo estado brasileiro em períodos diferentes, pode-se notar a estratificação desses momentos no modo como as cidades dessa região do rio Xingu foram se constituindo, com maior ou menor influência da rodovia ou do rio. Contudo, a cidade de Altamira torna-se um caso particular, pois congrega esse duplo movimento de ocupação, mantendo influência tanto do rio como da rodovia até os dias atuais.

${ }^{2}$ As Casas de Memória consistem em projetos museológicos de salvaguarda do patrimônio imaterial da área de influência da usina de Belo Monte, aprovados pelo Instituto do Patrimônio Histórico e Artístico Nacional (IPHAN), durante o licenciamento ambiental da obra. Esse trabalho ainda é desenvolvido em sua fase final, pela empresa Scientia Consultoria, na qual fui empregado até o ano 2012.
} 
correspondia também a essa ausência sentida dentro do trabalho que participei, embora tenha tido contato com a temática e com os indígenas de Altamira durante o próprio projeto.

A forma como conheci a região e que estabeleci as primeiras relações com as pessoas em Altamira, que constituíram meu arcabouço para desenvolvimento do projeto, foi determinada pela mediação da investigação de cunho histórico, mais precisamente das memórias sobre a região contadas pelos moradores locais. Minha localização em campo, por assim dizer, era sempre traduzida pelas intenções de meu trabalho com essas pessoas: o interesse pelos relatos de trajetórias de vida, pelo tempo passado. Dessa forma, eu me vi, em certo sentido, compelido a reportar-me sobre essa herança quando construí minhas intenções de pesquisa atualizadas para o projeto de mestrado. Contudo, não avalio a consideração do legado pelo prisma da obrigação, uma vez que, além de manter o interesse pelo assunto, compreendi os benefícios que esse acesso proporcionaria para meu trabalho em campo. Por sua vez, esse interesse confirmou sua importância na reconstituição das experiências indígenas durante os campos subsequentes.

Essas considerações, com intencional teor autoral, não se limitam à preâmbulos confidenciais da pesquisa; estão profundamente radicadas na forma como o estudo foi pensado. Remetendo às condições e intenções iniciais do projeto de pesquisa é possível compreender quais modulações as reflexões iniciais sofreram ao longo da pesquisa, e que também remetem ao desenvolvimento argumentativo da dissertação. Por ora, essa contextualização corresponde à necessidade de situar o modo pelo qual o interesse em aspectos da história dos indígenas da cidade de Altamira, presentes nas memórias históricas e relatos das trajetórias de vida, materializou-se na efetivação das questões colocadas para essa proposta etnográfica. Em síntese, a partir do exposto, a pergunta que se colocou nesse momento foi: uma etnografia da situação dos indígenas moradores da cidade de Altamira durante a construção de Belo Monte poderia corresponder ao interesse sobre suas histórias, por meio das memórias e relatos de trajetórias de vida?

O Capítulo 2 "Do Alto à Missão: histórias indígenas em Altamira-PA" é uma tentativa de responder afirmativamente a essa indagação. Dessa questão desdobram-se problematizações analíticas que se remetem aos usos das ideias de "memórias" e "trajetórias de vida". Como será apresentado, muito mais que métodos abrangentes e pré-definidos para dar conta de problemas específicos, essas noções são mobilizadas na pesquisa no sentido aproximativo que corresponde a tradução de enunciados sobre outras historicidades. Nesse 
sentido, o problema dessas "outras historicidades" (Gow, 2005) diz respeito às questões que a pesquisa é obrigada a lidar, tendo em vista a correlação entre as observações de campo e as contribuições da teoria antropológica dentro do debate com a história. Tais questões, de ordem teórico-metodológica auxiliaram a pesquisa na sua intenção de construir uma proposta reflexiva sobre modos particulares de contar e pensar as histórias interpeladas pelos interlocutores da pesquisa. Nesse sentido, a problematização do que seriam perspectivas Xipaya e Kuruaya sobre os eventos de ocupação regional exercidos pelos não indígenas, e também por outros povos indígenas, apresenta-se como questão fundamental para compressão histórica dos deslocamentos e residências que permeiam os relatos ouvidos.

O debate permitiu compreender as especificidades históricas da presença indígena na cidade de Altamira, apresentadas pelas versões Xipaya e Kuruaya. Tais contribuições permitem situar aspectos da experiência indígena na cidade esquadrinhados pela etnografia: os modos como as territorialidades urbanas e suas mobilidades abrigam redes de parentesco translocais que vão orientar sentidos de pertencimento e a produção de alianças entre indígenas e não indígenas de Altamira.

\subsection{Questões sobre parentesco}

Enquanto a pesquisa de campo dava forma ao interesse pelas histórias da presença indígena em Altamira era inevitável presenciar e participar de conversas nos círculos familiares que expunham diferenças e proximidades entre os interlocutores da pesquisa. Ao passo que as estratégias de pesquisa durante o primeiro campo para mestrado estiveram estruturadas no sentido da coleta dos relatos sobre memórias históricas e trajetórias de vida sobre indígenas relacionados principalmente aos bairros São Sebastião (Muquiço) e Jardim Independente (Missão), as situações de pesquisa insinuaram, em diversos momentos, as relações de parentesco como uma questão importante para os interlocutores, que deveria ser aprofundada pela etnografia. Munido de instrumentos para exploração dos problemas históricos da pesquisa, a incidência de eventos formulados em termos de parentesco tornavase cada vez mais latente durante o andamento do campo, assim como a vivência dos efeitos da construção de Belo Monte na vida diária dos habitantes de Altamira. Essas duas expressões do dia-a-dia entre os indígenas moradores da cidade ocuparam um tempo significativo do trabalho de campo, como pode ser percebido, por exemplo, nas menções constantes às tensões 
entre as famílias que integram o movimento indígena citadino de Altamira, bem como no excesso de reuniões e consultas aos moradores indígenas da cidade, requisitados por conta da presença de Belo Monte. Os relatos passavam a transbordar seu "exclusivo conteúdo histórico" referindo-se: não apenas a migrações como as mobilidades em circuitos urbanorural; não apenas às diferenças e semelhanças entre os antigos Xipaya e Kuruaya, mas reiterando pertencimentos e afastamentos de determinadas redes de parentesco; finalmente, não só ao contato interétnico, mas à mistura entre indígenas e não indígenas de Altamira. Todos esses enunciados falavam, no limite, de práticas que criam e recriam vínculos entre os Xipaya e Kuruaya de Altamira.

Ao mesmo tempo em que a etnografia examinava esses sentidos do universo Kuruaya e Xipaya, o estudo se via impelido a compreender determinados fatores abrangentes que permitiriam situar o recorte específico sem que esse se tornasse fechado em si mesmo, ou seja, compreender como as versões e atuações Xipaya e Kuruaya se situavam num horizonte mais amplo da presença indígena na cidade. Essa necessidade também correspondia a experiência de campo com outros grupos indígenas, permitindo correlacionar uma leitura sociológica para o problema contemporâneo da residência na cidade; como é possível visualizar, por exemplo, através das afinidades defendidas pelos interlocutores para unificação do movimento indígena citadino. Por isso o Capítulo 3 Entre parentes: etnografia das famílias Xipaya e Kuruaya de Altamira foi também uma análise das informações disponibilizadas pelos estudos de viabilidade ambiental de Belo Monte, preocupadas com o fenômeno indígena urbano na medida em que essa população era diretamente afetada pela construção da usina. Essa produção estará diretamente implicada com a organização política das associações indígenas que seguirá ao início da construção de Belo Monte, ao mesmo tempo em que essa também corresponde às forças internas do movimento indígena estruturadas por essas redes de alianças, aspectos acompanhados durante o trabalho de campo junto aos representantes e lideranças indígenas.

Se o domínio sobre as historicidades repousava sobre a experiência vivida dos idosos indígenas, a autoridade sobre os discursos históricos entre os Xipaya e Kuruaya vinculava-se ao campo das relações entre famílias. Essa evidência é mesmo percebida por meio das pequenas variações que as versões sobre a história do bairro da Missão, por exemplo, se apresentam. Assim, o modo como essas construções entre regimes de historicidades e versões históricas se apresentavam confluíam ao segundo plano investigativo da pesquisa, em que as questões determinadas pela etnografia configuravam-se no campo das relações entre as 
famílias Xipaya e Kuruaya que habitam a cidade. O reconhecimento do tema do parentesco como um campo tradicional da antropologia agregou à essa questão observada em campo um vasto debate travado no seio da disciplina, que traz à tona problemas fundamentais para o campo da etnologia indígena. As contribuições de Peter Gow (1991; 2012; 2014) sobre o parentesco como uma questão também de ordem diacrônica, ajudam a situar os problemas apresentados por esse contexto amazônico indígena, presentes, por exemplo, nos episódios recorrentes dos casamentos entre os Xipaya e Kuruaya e também com não indígenas (principalmente com os migrantes nordestinos vindos da época da borracha). O parentesco entre os indígenas é apresentado enquanto memória genealógica e, ao mesmo tempo em que expressa mais do que simples diagramas de casamento e filiação, fala sobre modos de conhecer e atuar que, no limite, estruturam mundos vividos. Parentesco para os Xipaya e Kuruaya é comer a comida de sua preferência, com seus pares, e nos seus locais apreciados. Como defendeu Sahlins (2011), o parentesco implica consanguinidade, afinidade, comensalidade, corresidência: é um princípio orientador de práticas de mutualidade e de compartilhamento que produzem identidades, ao mesmo tempo em que é uma lógica de parcialidades e conflitos que criam diferenças:

"A catalogue of commonplace post-natal means of kinship formation would
thus include: commensality, sharing food, reincarnation, co-residence, shared
memories, working together, adoption, friendship, shared suffering, and so on.
But the performative modes of kinship known to anthropology - if not to
socio-biology or evolutionary psychology - are indefinitely many, inasmuch
as they are predicated on particular cultural logics of relatedness" (SAHLINS,
p. 5, 2011).

Compreender as dimensões simbólicas que constituem o parentesco é também se lembrar da vizinhança como operadora das relações entre indígenas e com não indígenas. Combinando o plano de análise de discursos e práticas que se desdobram do parentesco, identificado como fragmento privilegiado ${ }^{3}$ da experiência coletiva, a dissertação pretendeu traduzir parte dos valores de vida considerados fundamentais para os interlocutores da pesquisa. Se a ideia de parentesco tende a demarcar as manifestações de filiação e aliança sob os pontos de vista indígenas, a importância da corresidência permite desvendar as

\footnotetext{
${ }^{3}$ A percepção de que valores de parentesco e vizinhança não são os únicos operadores possíveis para se compreender as relações entre essas pessoas e suas histórias, é fundamental para que não se produza uma ideia distorcida sobre outros aspectos essenciais da vida coletiva como, por exemplo, as relações econômicas e comerciais que também estruturam relações, ou mesmo a violência dos conflitos, impostos por diferentes termos, como disputas fundiárias.
} 
transformações dos laços de parentesco, levando-se em conta a forma como os casamentos foram se reconfigurando no espaço e no tempo desses grupos marcados pelo intenso contato. Essa dupla condição dos valores de parentesco - casamento e vizinhança - reitera tanto sua importância histórica, como "fonte das respostas das pessoas nativas às novas situações" (GOW, 2006), como também sua razão intersubjetiva, caracterizada como "mutuality of being” por Sahlins (2011), criando códigos coletivos para coesões e dissenções. Parentesco implica criação e recriação de práticas e discursos entre os interlocutores, por sua vez, capazes de descrever perspectivas sobre proximidades e distâncias, sobre continuidades e mudanças, como sugere a asserção de Viveiros de Castro:

"A ideia de vizinhança serve para sublinhar que 'comunidade' não é uma realidade genética; por outro lado, colocar "relações de parentesco" na definição permite que se contemplem possíveis dimensões translocais dessa 'comunidade"” (VIVEIROS DE CASTRO, 2006, p. 11).

Enquanto ponto de intersecção, o parentesco entre os Xipaya e Kuruaya de Altamira é histórico e político, pois não apenas relaciona as narrativas históricas sobre os grupos às trajetórias familiares, como atualiza as relações entre os interlocutores por meio da produção de convergências e dissidências, que surgem como propostas aos novos desafios determinados pelas conjunturas sociopolíticas. O parentesco entre os Xipaya e Kuruaya de Altamira defende boas práticas de residência e alimentação, que serão abordadas pela etnografia nos capítulos que se seguem. Os eventos descritos são interpretados a partir da noção de "bem viver”, tradução do contexto etnográfico dos Piro proposta por Gow (1991; 2012; 2014), que serve de inspiração para leitura dos valores aventados pelas práticas e discursos dos interlocutores da presente pesquisa ${ }^{4}$. Estendendo o debate sobre parentesco à compreensão das formulações políticas entre sujeitos da pesquisa, a dissertação acrescenta à problematização a discussão sobre a organização do movimento indígena citadino, acompanhando a formação das associações e a militância das lideranças, ambas emaranhadas nas redes das famílias extensas, que irão sustentar ou anular reivindicações que professam tentativas de melhorar a vida.

\footnotetext{
${ }^{4}$ É importante indicar que, embora o autor tenha orientado grande parte das discussões desenvolvidas na presente dissertação, com potência conceitual para pensar questões etnográficas observadas - balizadas principalmente pela discussão em torno das categorias nativas sobre história e parentesco, e assim sobre suas definições de mistura - seu contexto de campo é bastante diferente do encontrado pela presente pesquisa. A questão da residência na cidade é um elemento fundamental da vida coletiva Xipaya e Kuruaya e que entre os Piro de Gow se insere apenas no horizonte das classificações nativas sobre os espaços (GOW, 1991).
} 


\subsection{Questões sobre etnicidade}

A exploração das formas de organização dos indígenas moradores de Altamira cria acessos para uma melhor compreensão da categoria "índio citadino", com a qual a maior parte dos indígenas da cidade tendem a auto referir, principalmente em contextos de reivindicação política. Essa politização, nesse sentido, considera as situações em que os indígenas citadinos são chamados a afirmar sua identidade indígena perante agentes e instituições que põem a etnicidade como questão. Embora a categoria índio citadino esteja presente em muitos discursos dos interlocutores da pesquisa, localizando as situações em que são mobilizadas podemos perceber que seu uso é referido normalmente a presente situação dos indígenas, sendo que, nos contextos das histórias sobre os antepassados, por exemplo, termos como “caboco" Xipaya ou Kuruaya são mais recorrentes. Pensar nos sentidos dessa transformação passa pela compreensão de como os Xipaya e Kuruaya se situam nos processos de ocupação e desenvolvimento da região, desde a histórica ligação com a formação da cidade de Altamira, passando pelas funções que desempenharam no "desbravamento" das regiões dos rios Iriri e Curuá na exploração econômica da seringa, até a conjuntura atual, em que a atuação dos movimentos indígenas perante as consequências de Belo Monte tem importantes contribuições desses grupos que mantém relações estreitas com a cidade e com as aldeias.

Durante a elaboração do projeto de pesquisa chamava atenção os problemas sobre os usos dessas categorias de identidades, trazendo à tona questões sobre etnicidade abordadas por uma vasta bibliografia da antropologia. Assim era definido o objeto de estudo: "A presente proposta de estudo concebe como foco principal que as possíveis
fronteiras desse fenômeno de identificação étnica sejam acessadas
inicialmente, não segundo a descrição da articulação entre as reivindicações
que essas populações oferecem no contexto atual e seu processo de ascensão
pelo código do Estado, mas a partir de um estudo detalhado de um bairro: uma
etnografia dessas categorias de identificação e diferenciação, que acionam
etnias e etnônimos, entre outros; e as atribuições relativas aos processos
históricos e de espacialidade, como são construídas nos imaginários e nos
modos de interações entre os moradores do bairro. Em síntese, não irei partir,
a princípio, do movimento político representante das atuais demandas das
etnias indígenas citadinas de Altamira, mas sim seu substrato, considerado a
partir das categorias locais que acionam e relacionam história e parentesco".
(ARNAULT, p. 6, 2013). 
A perspectiva, então, foi de aproximação dos problemas ligados à identificação étnica a partir dos pontos de vista trazidos pelos interlocutores da pesquisa. Isso implicaria na análise dos enunciados nos quais houvesse ocorrência dessas categorias: quais etnias e etnônimos e seus significados num determinado discurso. Sobre esse ponto, os campos de estudo realizados durante toda a pesquisa foram fundamentais. A identidade, como um problema para investigação, foi trazida ao projeto de pesquisa por conta do caldeirão multiétnico no qual se ancora a situação dos indígenas na cidade de Altamira; interessou à pesquisa as relações entre indígenas e não indígenas para constituição das experiências indígenas citadinas, ou mais especificamente, como são situadas as relações entre esses grupos nas formas dos casamentos "interétnicos", uma recorrência de longa data entre os Xipaya e Kuruaya. Apenas com seu sentido acenado, a questão ligada à identificação étnica dos indígenas que moram na cidade sempre esteve vinculada, da forma como proposta pela pesquisa, aos processos de parentesco, de aliança e descendência, que se configuram entre indígenas no espaço da cidade, contudo essa forma era ainda bastante obscura durante a elaboração do projeto. Esses contornos passaram a se delinear após a primeira experiência de campo, quando foram observadas as correlações que os interlocutores estabeleciam entre as noções de "caboco" Xipaya e Kuruaya e de índio citadino, definidas pelas relações entre as famílias indígenas, mas que se estendiam, por sua vez, aos modos de relação com os não indígenas moradores da cidade e agentes institucionais desse contexto. Ao mesmo tempo o contexto também deve ser problematizado pela etnografia uma vez que na própria categoria "índio citadino" é latente a questão da territorialidade urbana. Essa latência ecoa, mais uma vez, através das questões que a etnicidade impõe, pois mesmo a categoria afirmativa é uma resposta à ideia de que indígenas e cidades não são compatíveis. Avançando sobre essa discussão, a dissertação encontra afinidades da etnografia ameríndia em contextos citadinos, entre a etnologia indígena (Lasmar, 2005; Nunes, 2010; Andrello, 2006) e a antropologia urbana (Andrade, 2009, 2012), que influenciaram a pesquisa propondo, em termos gerais, perseguir modos de espacialização característicos dos grupos indígenas residentes em meios urbanos como resposta etnográfica contra quaisquer critérios estanques de etnicidade e urbanidade que sejam anteriores ao comprometido estudo das categorias e agências nativas. Retém-se dessas contribuições que as questões indígenas na cidade falam, antes de tudo, sobre processos de residência, migração e fluxo, que proporcionam persistências, adaptações e novas formulações às culturas implicadas nesses espaços e movimentos. Mais uma vez, as 
questões sobre etnicidade aparecem como representações, nesse caso, de processos desenvolvidos no espaço urbano, como a autoafirmação indígena citadina. Para além desses, as percepções e ações dos agentes sobre e na cidade referem-se não apenas a modos de vida específicos como projetam desejos e preferências que estão intimamente relacionados aos espaços de vivência em Altamira e seu entorno.

Por sua vez, ainda diante de formulações sobre etnicidade, pode-se afirmar que os grupos citadinos de Altamira experimentam uma situação limite entre dois processos tradicionalmente abordados pela etnologia ameríndia: o "virar branco" e o "reassumir-se índio" ". Os discursos sobre identidade entre os Xipaya e Kuruaya de Altamira se referem a esses dois momentos: se nas histórias dos velhos, avós que nasceram nas aldeias antes da migração para cidade, esse deslocamento assume as características do "virar branco", o retorno às aldeias, realizados pelos netos, retém muitos sentidos do se "reassumir índio". Num outro contexto, se os discursos políticos do movimento indígena falam dos problemas do "virar branco", sobre os interesses e objetivos da militância indígena, os indígenas de Altamira, há muito tempo residentes na cidade, foram e continuam sendo cabocos Xipaya e Kuruaya perante si e a sociedade envolvente - mesmo que discurso de fora seja carregado de preconceitos. Em resumo, esse contexto impôs ao pesquisador uma dificuldade analítica: a noção limitada de identidade não foi capaz render satisfatoriamente sobre o problema formulado em termos nativos, como afirma Viveiros de Castro (2006): "Os antropólogos querem, justamente, garantir essa identidade indígena. Só que não garantem; só o índio é quem se garante". Ao mesmo tempo, observando os processos de transformação dessas noções de pertencimento étnico, as quais se referem os indígenas da cidade de Altamira, é possível situar em seus próprios termos os valores que estão em jogo na produção de identificações e pertencimentos. Um fenômeno atual que parece fundamental nesse sentido é o deslocamento da atribuição do amálgama Xipaya-Kuruaya - reivindicada em muitos momentos durante os estudos ambientais de Belo Monte, por exemplo - para uma acentuação da distinção entre os Xipaya e os Kuruaya, muito embora se verifique que a origem das pessoas desses grupos na cidade seja normalmente no mínimo dupla, e na maior parte dos casos tripla, a partir da herança não indígena. Contudo, pensar segundo esquema seria incorrer no erro de conceber as identidades indígenas como anteriores à sua produção e mobilização, ou, mais grave, distantes da concepção que os interlocutores têm delas. Enquanto objeto de

\footnotetext{
${ }^{5}$ Retém-se, da ampla discussão antropológica acerca dos processo de mudança e dos modos de classificação ameríndios, as propostas que convergem sob a preocupação com as transformações formuladas em termos nativos, ressaltando a contribuição da etnografia. Ver Kelly (2005), Albert \& Ramos (2000), Gow (1993).
} 
aprofundamento pela pesquisa, o acirramento das distinções entre os Xipaya e Kuruaya se move em torno das relações entre as famílias e que estabelecem correlações com as organizações políticas dos indígenas citadinos. Novamente, mantém-se a sugestão, como poderia ser apresentada por Gow $(1991 ; 2012: 214)$, de que a identidade é também formulada em termos de parentesco, embora a primeira apresente-se sob enunciados caracterizados como discursos políticos de etnicidade, aplacados pelos dispositivos de auto-reconhecimento e reconhecimento pela comunidade. Mantendo a atenção à "etnicidade" anunciada em termos nativos, podemos deslocar o conceito de identidade étnica por meio de explicações dos interlocutores sobre pureza e mistura, que tendem a destacar o fluxo irrefreável da segunda. Nesse sentido, a etnografia não abandona a tentativa de compreender algumas das influências e sobreposições que o problema da identidade étnica inflete sobre os interlocutores, principalmente aquelas que alimentam inquietações e tensões internas que se formaram em torno das tentativas de responder à pergunta inquisitiva: quem, afinal, são vocês?

\subsection{Questões sobre movimento indígena}

A constituição do movimento indígena citadino, embora anterior à chegada de Belo Monte, encontra seu princípio relacionado à unificação da luta indígena contra o antigo projeto hidrelétrico de Kararaô ${ }^{6}$. Nesse momento, como aludem alguns interlocutores da pesquisa, houve um grande processo de aprendizagem, principalmente daqueles indígenas moradores da cidade, antes absorvidos pela vida urbana e distantes das disputas territoriais, que passavam a se engajar na luta por direitos dos povos indígenas. Com a retomada desse movimento, agora contra a construção do projeto de Belo Monte, a mobilização de indígenas e ribeirinhos, auxiliados pelos movimentos sociais e organizações não governamentais, como o Instituto Socioambiental, Fundação Viver Produzir e Preservar, Movimento Xingu Vivo para Sempre, entre outas, e o fundamental apoio da Prelazia do Xingu, houve novas condições que transformaram o quadro de organização política dos indígenas da região xinguana. Nesse sentido, conquanto não seja possível estabelecer que a interferência de um agente externo determine as formas políticas que se estabeleceram entre indígenas e não indígenas de Altamira, é possível vislumbrar em que medida esses movimentos ativistas foram obrigados a responder a essa nova situação, tornando-se essa, por conseguinte, uma questão fundamental

\footnotetext{
${ }^{6}$ Informações detalhadas sobre os projetos hidrelétricos na região serão apresentadas no capítulo 3, "A política indígena na cidade de Altamira: desafios antes e durante Belo Monte".
} 
para a presente pesquisa. Tal questão está intimamente relacionada às experiências Xipaya e Kuruaya abordadas ao longo da pesquisa, uma vez que a posição desses grupos indígenas tem características particulares dentro dos grandes processos de ocupação e desenvolvimento planejados e nas implementações pelos agentes nacionais (ciclos da borracha, rodovia transamazônica, mineração e novos projetos hidrelétricos). É preciso deixar claro que essa problematização não perde de vista o objeto fundamental da etnografia que são os pontos de vista e agências dos indígenas que hoje residem em Altamira.

O desenvolvimento da organização política dos indígenas citadinos, proporcionado pelos avanços da Constituinte do final dos anos 1980, criou condições institucionais necessárias para a defesa e garantia dos direitos sociais dos grupos indígenas. A expressão desse processo para ao movimento indígena citadino correspondeu à valorização estratégica da cultura dos indígenas moradores da cidade, processo duplamente denominado pelos interlocutores como "resgate e fortalecimento cultural". Um dos momentos fundamentais desse movimento está atrelado à criação da primeira organização institucional de indígenas da cidade, a Associação dos Indígenas Moradores de Altamira - AIMA. Essa associação nasce com base na atuação de lideranças indígenas que fizeram um levantamento das famílias residentes na cidade, ao lado da promoção de ações de valorização cultural, como projetos de resgate das tradições, aproximando diferentes gerações da cidade. Assim, a etnografia pôde observar que um dos principais instrumentos políticos dessa organização dos indígenas citadinos está baseado na institucionalização das relações familiares na forma das associações indígenas. Atualmente, além da AIMA, atuam como associações dos indígenas citadinos a Kirinapãe e a Inkuri organizadas em torno de outros núcleos familiares Xipaya e Kuruaya e também a associação de ribeirinhos Tyoporêmo vinculada aos moradores do bairro São Sebastião, além da associação Juruna citadina Tubyá, e da Kuximã dos Juruna da aldeia São Francisco na Volta Grande do Xingu. Ao lado desses eventos de institucionalização, apresentam-se diversos momentos de tensão entre indígenas e não indígenas da cidade que compõem polêmicas em torno da identidade indígena citadina. Desse quadro, o surgimento do fator Belo Monte acirra determinadas questões, como pode ser observado da politização das genealogias produzidas pelos estudos ambientais entre os indígenas de Altamira. Compreender as interfaces entre uma organização pode-se dizer, interna às famílias indígenas, baseadas em critérios de parentesco e corresidência, e as formas instrumentalizadas ou mesmo institucionais do movimento indígena na sua relação com outros agentes, foi uma questão fundamental da etnografia. Formulada em termos nativos por uma interlocutora que 
mencionava um conflito interno ao movimento indígena citadino: "O problema é que ele esqueceu que com os parentes a coisa é diferente... na política ele sabia falar, mas esqueceu de falar com os parentes".

As expectativas trazidas pela implantação de Belo Monte têm uma sensível atuação na vida como um todo na região de Altamira. As previsões com relação ao reassentamento e às contrapartidas socioambientais caracterizadas, a maior parte do tempo, enquanto projetos não apenas de compensação contra impactos provocados pela obra, mas também como medidas preventivas diante das pressões sobre a ausente infraestrutura regional, tornam-se os principais deflagradores da insatisfação local com as promessas da obra. Esses são alguns dos ingredientes encontrados pela pesquisa nos campos realizados entre início do ano de 2014 até meados de 2015, e que compõem a efervescente situação na qual permanecerão os indígenas da região de Altamira até o término da obra. Desconsiderar a magnitude do fator Belo Monte é um descuido impensável para uma etnografia comprometida com as manifestações dos indígenas citadinos. Ao mesmo tempo reduzir a situação dos indígenas de Altamira à referência aos projetos hidrelétricos, ou quaisquer outros agentes externos, seria não apenas trair a elevada proposta da antropologia como também deturpar a significativa contribuição dessas populações nessa região. Percorrendo as formas de auto-organização política do movimento indígena citadino e das associações indígenas da cidade, a etnografia destaca as agências indígenas que aproveitam os espaços criados para a política indigenista durante a construção da obra, e as tentativas de resistência contra as destruições inerentes a esse grande empreendimento de impactos incomensuráveis.

Ciente de que os três planos investigativos poderiam ser mais bem explorados exclusivamente, a etnografia manteve a proposta como saída ao problema levantado do viver bem, e da busca por uma vida melhor entre os interlocutores nesses tempos de Belo Monte. Espera-se, dessa forma, que a dissertação contribua ao debate antropológico implicado às suas situações de estudo. 


\section{DO ALTO À MISSÃO: HISTÓRIAS INDÍGENAS EM ALTAMIRA- PA}

\subsection{Relatos e documentos: apontamentos para uma abordagem etnográfica das histórias indígenas}

O interesse etnográfico sobre os bairros São Sebastião/Muquiço e Jardim Independente/Missão foram suscitados pela importância histórica dos locais, revelados, como foi apresentado, quando do levantamento do patrimônio histórico e cultural de Altamira no trabalho de consultoria. Esse interesse, é importante destacar, agravou-se com a situação a qual essas regiões da cidade estão passando com a construção da usina de Belo Monte: são bairros que terão suas áreas parcialmente alagadas pelo reservatório.

Vislumbrando a importância histórica desses bairros, foram retomadas leituras de textos de apoio sobre a história da região, principalmente os relatos de viajantes, como Príncipe Adalberto da Prússia (1977), Karl von den Stein (1942), Coudreau (1977), entre outros textos de observação direta, como o da ornitóloga e naturalista do Museu Goeldi, Emilia Snethlage (1910) e do etnógrafo Nimuendaju $(1948 ; 1981 ; 1982)$, que fundamentaram a investigação que relacionou o bairro São Sebastião, também conhecido como Muquiço, como local onde foi estabelecida a missão jesuíta de aldeamento dos indígenas da região do Xingu, considerada formadora da cidade de Altamira. Quando da pesquisa de levantamento do patrimônio cultural, pôde-se identificar alguns elementos dessa história, presente nos relatos dos antigos moradores desse bairro e de Altamira. Embora as memórias dos habitantes não pudessem remeter-se ao tempo das missões religiosas, as entrevistas revelavam a magnitude da presença indígena na constituição do bairro e mesmo atualmente, ainda que a proporção de famílias que se declarem indígenas, residentes nesse bairro, já tenha sido mais expressiva no passado, conforme é percebido nos relatos e fontes históricas.

Em certo sentido, os anseios que culminaram na proposta de estudo etnográfico do bairro tiveram em seu horizonte a possibilidade de retraçar as ligações históricas sugeridas pelos documentos, ou seja, de certa forma uma verificação de alguns episódios constitutivos da cidade de Altamira, em que constasse a significância da presença indígena no processo. Visto o modo como se apresentava, tais intenções foram logo reposicionadas, na medida em que uma pesquisa etnográfica ao lado de uma historiografia documental exaustiva sobre o bairro não foram consideradas prioridade na realização da pesquisa. Inspirada nas pesquisas 
de Peter Gow (1991; 1997 e 2006), cuja proposta analítica reside na exploração sistemática dos discursos locais sobre identidade, cultura e história, buscou-se conduzir o projeto de pesquisa com a intenção de construir uma etnografia a partir de memórias históricas dos moradores sobre o bairro, que lançam luz sobre a presença e agência indígena na constituição urbana de Altamira. Com essa proposta pretende-se que o relato etnográfico seja capaz de refletir sobre os pontos de vista indígenas com relação aos processos de ocupação e urbanização do bairro e, consequentemente, permitindo pensar os modos como se deram algumas transformações sociais em Altamira.

Inserindo-se num clássico debate entre a antropologia e modos de produção do conhecimento histórico, essa proposta etnográfica incide sobre noções de etno-história e história indígena que se mantêm positivamente instáveis no seio da disciplina. Reafirmando o pressuposto etnográfico como fundamento da pesquisa, a história surge aqui sob os auspícios da indagação etnográfica, em que a produção de dados é observada enquanto fonte num sentido distante de concepções sobre o conhecimento histórico preocupadas com parâmetros externos de verdade. Essa orientação, claramente devedora das reflexões antropológicas, insere-se na discussão sobre o conhecimento histórico por meio de outros paradigmas sobre a natureza desse conhecimento, fornecidos, por sua vez, pelas leituras permitidas pelo que se convém chamar de teorias nativas. Determinada dessa forma, essa investigação histórica ampara-se na assim denominada, por diversos campos de conhecimento, perspectiva êmica ${ }^{7}$. A relação entre história e antropologia, remetendo-se a amplas discussões que se mantêm vibrantes menos por sua originalidade do que por sua potencialidade, está localizada na presente pesquisa como uma importante questão que, por ora, resolve-se na definição do método etnográfico como meio de acessar as concepções dos indígenas da cidade sobre suas histórias. Retém-se, inicialmente, a preocupação em coletar as histórias contadas por essas pessoas, orientadas pela investigação em torno da formação dos bairros, de forma que esse

\footnotetext{
${ }^{7}$ Fazendo um balanço das questões em torno das concepções de história indígena e etno-história para a disciplina histórica, Cavalcante (2011) aponta as acepç̃os relativas aos dois conceitos. Referindo-se a etnohistória, indica-a: como disciplina acadêmica independente; como compreensão e/ou representação da história e do tempo nos termos próprios dos grupos indígenas; como uma etnociência, que compartilha os saberes indígenas e sua contribuição ao conhecimento histórico; e como um método interdisciplinar, cunhado, principalmente, na relação entre antropologia, história e arqueologia. Defendendo o uso do termo história indígena para o campo da história contemporânea preocupada com os fenômenos históricos dos grupos indígenas, Cavalcante conclui retomando as contribuições que antropologia deu ao debate: reivindicando uma história indígena que não seja temporalmente determinada pela história colonial; promovendo a descolonização do discurso histórico, ao restituir os indígenas como sujeitos históricos plenos; ao mesmo tempo em que representa as relações desiguais entre indígenas e não indígenas, sem contudo deixar de observar a agência indígena no contato.
} 
procedimento possa permitir indagações que comportem correlações com outros conhecimentos, incialmente históricos, mas de outra natureza, como os relatos de viajantes e outros documentos históricos.

O lugar que ocupam os relatos de viajantes e documentos históricos nessa argumentação não deve ser o da pesquisa historiográfica, a ser subsidiada pela descrição etnográfica sobre as recordações históricas dos moradores, ou seja, um estudo preocupado com evidências históricas desses discursos verificáveis em outras fontes. Relacionando as informações presentes nessas fontes históricas com a presença indígena no bairro e em Altamira de forma geral, é possível traçar reflexões em torno da situação atual vivida pelas pessoas. Embora a bibliografia histórica seja escassa, é de fundamental importância para os períodos em que a memória não chega. Nesse sentido serão textos lidos etnograficamente, isso significando que, mesmo não sendo todos interlocutores diretamente interessados nas histórias indígenas de Altamira, pode-se compreendê-los como autores de determinados olhares que lançam luz sobre essas histórias na região. Uma vez traçadas e pensadas as interconexões entre histórias indígenas em Altamira, será também possível compreender como a presente etnografia foi obrigada a transbordar os limites do bairro no qual se pretendeu focalizar os estudos, pensados mesmo ainda ao nível das reflexões em torno de história e antropologia ${ }^{8}$.

A discussão em torno da história dos bairros na presente etnografia pretende consolidar dois momentos reflexivos distintos, contudo não desligados: pensar as possibilidades de compreensão e interpretação da história da presença indígena na cidade de Altamira, refletindo sobre o conhecimento histórico produzido pelos discursos Xipaya e Kuruaya e não indígenas da cidade e, quando cabível, comparando com aspectos gerais do histórico de ocupação e desenvolvimento dessa região, questão essa, por assim dizer, mais propensa aos interesses da investigação histórica; e verificar de que forma esses discursos sobre a história da presença indígena nesses determinados bairros e em Altamira, acionam ordenações sociopolíticas entre indígenas e não indígenas residentes atualmente na cidade, no contexto das transformações trazidas por Belo Monte, o que significa dizer, a meu ver, que

\footnotetext{
${ }^{8}$ Conforme apresentado na Introdução da dissertação, a etnografia compreende uma investigação que intersecciona três aspectos da vida social de indígenas citadinos em Altamira: histórias, parentesco e política.
} 
essas histórias ocupam um lugar decisivo no presente, e que operam, como se pretende demonstrar, nas projeções do porvir? ${ }^{9}$

No artigo "Canção Purus" Peter Gow (2005) trabalha com distintas ordens de conhecimentos históricos que convergem num mesmo espaço de disputa: a análise de duas descrições de uma refeição no rio Purus no começo do século XX, através de uma canção Piro e um ensaio breve de Euclides da Cunha. A partir dessa análise comparativa o autor propõe que esse específico evento local se insere em regimes de ação simbólica contrastantes que irão resultar em dois modos diferentes de produção de sentido: do ponto de vista do escritor brasileiro o episódio é referenciado pelos sentidos da nacionalização daquela região do país, enquanto as canções piro remetem-se à mesma situação através de esquemas de "tribalização" coerentes com o sentido Piro. A nacionalização toma os eventos locais e os esquenta no tempo-espaço do Estado-Nação, enquanto a tribalização desativa os perigos potenciais dos eventos locais. O primeiro lembra, o segundo esquece. Segundo o autor:

"Há dois pontos aqui. Primeiro, que a nacionalização do passado é virtualmente o produto inevitável de como viemos a conhecê-lo por meio dos arquivos. Da Cunha podia talvez imaginar um futuro pan-americano ou antiimperialista, mas apenas podia fazê-lo pela brasileirização das palmeiras que cresciam em Curanjá, que mais tarde passaram a fazer parte do Peru. O passado do sudoeste da Amazônia nos chega quase exclusivamente por um arquivo que é construído em termos explicitamente nacionalistas. É uma dificuldade infernal pensar além desses enquadramentos do passado e perceber a simples questão de que, em 1865, Curanjá estava, muito literalmente, em lugar nenhum, enquanto não tinha sido ainda produzido qualquer documento que pudesse nos dizer retrospectivamente onde estava. Em segundo lugar, não temos testemunhos dessas pessoas que identifiquei como agentes-chave, os povos indígenas". (GOW, p. 456, 2005).

O autor prossegue sugerindo que esses fenômenos, que podem ser considerados como históricos no sentido convencional do conhecimento científico, tendem a ser interpretados como produtos de relações estabelecidas pelos Estados-Nação, do Peru e do Brasil, como no caso analisado por Gow. Contudo, devemos nos situar, talvez principalmente como

\footnotetext{
${ }^{9}$ Os desenvolvimentos a respeito de aspectos da situação atual de alguns indígenas na cidade de Altamira serão apresentados nos capítulos seguintes.
} 
antropólogos, um passo atrás dessa leitura, quando uma sequência de eventos iniciada por povos indígenas transcende limites locais e se vê transformada por efeitos ligados a EstadosNação, percebidos recorrentemente como suas causas mas que, na realidade, são fenômenos tribais, conforme expressa Gow, "produtos de 'sociedades' frias como os povos Piro e Manitineri” (GOW, p. 456, 2005.). Nacionalização seria então “o contínuo eclipsar de ações e sua representação como efeitos de relações sociais nacionais" (GOW, p. 456, 2005.). Ainda, Gow provoca dizendo que o modo de nacionalização, representado na carta de Euclides da Cunha situa-se como uma doença "paranoica", no sentido atribuído pelos Piaroa sobre o poder xamânico (GOW, 2005 apud OVERING, 1975), na medida em que um pensador muito poderoso é visto como alguém que pode ver o mundo como um único lugar, o que significa também, por sua vez, que pode perder o controle das consequências de seu poder. Assim o autor confere aos modos de tribalização uma perspectiva divergente sobre o poder do conhecimento, como nas canções piro analisadas:

"Eles suavizam as ramificações dos eventos do passado, ramificações estas que ameaçam contagiar as relações sociais presentes $\mathrm{e}$ as destruir. Ramificações contagiantes aquecem as coisas e confrontam os Piro com sua imagem como uma "sociedade quente". Para manter a escala desejada em suas relações sociais, os Piro têm de se livrar da história e até mesmo dos meios de esquecê-la". (GOW, p. 461, 2005).

$\mathrm{O}$ artigo de Peter Gow é retomado aqui por sua instigante maneira de ler distintos discursos que podem ser localizados dentro de um mesmo evento histórico. A consideração de um "mesmo evento" pode ser interpretada como uma grande provocação do autor sobre como conhecimentos distintos lidam com escalas desiguais, cristalizando representações que valorizam os conhecimentos de formas divergentes. Considerando o argumento do autor, assume-se que a possibilidade de comparar distintas fontes sobre as histórias de Altamira, na presente pesquisa, passa pela necessária consideração dessa divergência fundamental. Assim, serão expostas as relações entre os antigos relatos históricos das viagens do príncipe Adalberto da Prússia (1977), e da naturalista e ornitóloga Emilia Snethlage (1910) pela região xinguana, ao lado das trajetórias de vida dos moradores Xipaya e Kuruaya, e também de alguns não indígenas de Altamira, como forma de apresentar um feixe de reflexões em torno de valores do tempo passado para os atuais moradores da cidade, em contraste com os projetos de ocupação que se perpetuaram na região. Ainda, a dissertação recupera nesse momento as informações históricas descritas por Nimuendaju, essencialmente apresentadas 
no volume 3 do "Handbook of South American Indians: The Tropical Forest Tribes" publicado no ano 1948, especificamente no verbete escrito pelo autor, "Tribes of The Lower and Middle Xingu River", por se tratar de uma fonte etnográfica privilegiada sobre os grupos interlocutores da pesquisa. Desenvolvendo a proposta analítica de interface entre os discursos, assume-se o risco da transposição da sugestão analítica de Peter Gow, apanhada nos conceitos de nacionalização e tribalização, para o campo de estudo da pesquisa. Embora a "forma histórica" da trajetória de vida não possa ser imediatamente traduzida nos termos da significação operada pela noção de tribalização, proposta por Gow, a análise inspira-se nesse esquema para pensar as particularidades dessas histórias contadas.

\subsection{Missão Tavaquara: análise de um documento histórico sobre Altamira}

Embora o Príncipe Adalberto da Prússia (1811-1873) não tenha realizado sua viagem pelo rio Xingu por motivos imediatamente pertinentes aos do interesse imperial - tal como guarda a carta de Euclides da Cunha citada por Gow (2005) - nem dedique suas descrições aos objetivos científicos ${ }^{10}$, seu relato guarda referências a problemas de íntima relação com as preocupações gerais de sua época. O relato do Príncipe Adalberto da Prússia trata de sua viagem no ano de 1842 através dos rios Amazonas e Xingu (1977) - com uma breve descrição sobre sua estadia na cidade do Rio de Janeiro - podendo ser considerado um dos principais documentos sobre a geografia e história dessa região, citados tanto por outros viajantes posteriores, como também por pesquisadores recentes ${ }^{11}$. Além de manter-se como um dos primeiros documentos escritos sobre a região, e também de fácil acesso ${ }^{12}$, o relato guarda algumas descrições sobre os indígenas do Xingu com significativa riqueza de detalhes, alvo do interesse desse trabalho.

A viagem do príncipe da Prússia ao rio Xingu, segundo o mesmo, fruto das suas fantasias e desejos de infância sobre os trópicos, foi movida pelo especial interesse do monarca com relação à existência de "índios selvagens" na região, confirmada por seus

\footnotetext{
${ }^{10} \mathrm{Na}$ apresentação do livro o autor alerta: "não procureis, caro leitor, nem pesquisas científicas ou doutas dissertações, nem descrições de perigosas aventuras, ou feitos famosos nestas páginas, que nada contêm senão o desataviado diário duma simples viagem de recreio muito longo, para nós alemães". (ADALBERTO, p. 12, 1977).

${ }^{11}$ Ver: Snethlage (1910); Nimuendaju, (1948;1981;1982); Patrício, (2000), entre outros.

${ }^{12}$ Alguns documentos dos próprios jesuítas sobre a missão foram mencionados durante a pesquisa de campo, contudo não foi possível localizá-los ou ter acesso a eles.
} 
intermediadores brasileiros. O relato transcorre então com excessivas descrições fisionômicas das paisagens amazônicas, sempre acompanhadas de observações, comparativas, entusiastas e projecionistas. Ao mesmo tempo, quando o caminho encontra as localidades habitadas, como as vilas e povoações nas beiras dos rios, o autor preocupa-se em recuperar o que lhe era possível sobre a constituição do local, traçar características demográficas e apresentar algumas descrições de hábitos de vida, também revelando algumas tentativas de diálogo com os moradores, dificultadas em grande medida pela necessidade de tradução, da língua indígena para o português e, finalmente, para o alemão.

Não deixa dúvidas que, pelo quadro elaborado na perspectiva do monarca prussiano, a região do médio Xingu a essa época, que começa onde hoje se localiza a cidade de Altamira, mantinha inquestionável e maciça presença indígena, fazendo da região um campo considerado ainda inexplorado e selvagem, habitado por índios ainda não batizados. Contudo, contrapõe-se no próprio relato do autor, a essa visão bastante condizente com o espírito civilizador e as ambições do estado imperial, suas caracterizações da riqueza da vida social dos habitantes indígenas, que embora não abundem as páginas do livro, são sugestivas em suas asserções. Em alguns momentos essas descrições vêm acompanhadas de elogios ao modo de vida natural virtuoso desses homens, supostamente distantes das contaminações da civilização, a despeito de termos acesso à situação clara de contato com esses indígenas, o que inclusive permitiu a viagem do aristocrata.

É interessante notar como no primeiro trecho da viagem, entre o rio Amazonas e o baixo rio Xingu, até onde se encontra a atualmente denominada Volta Grande, destacam-se as antigas ocupações de origem colonial de Gurupá, Porto de Moz e Sousel (atual Senador José Porfírio). As menções sobre a presença dos negros no toque do benguá na festa de Santo André em Porto de Moz, bem como a população miscigenada de que fala em Gurupá e Sousel, sugerem como a ocupação dessas áreas ocorreu. A construção do forte com canhões em Gurupá, na confluência do rio Amazonas e Xingu, que garantiu a expulsão de holandeses e ingleses da região no século XVII, exemplifica como a ocupação dessa área foi estratégica desde os tempos coloniais. Até então, Gurupá servia de entreposto de revista de todas as embarcações que subiam o Amazonas e Xingu. O autor menciona que Gurupá foi antes ocupada pelos índios tupinambás.

Mais interessante é o momento de chegada em Sousel, onde o príncipe encontra a comunidade do vigário Torquato Antônio de Souza, que foi missionário primeiramente entre 
os Munduruku e então era responsável pela catequese no Xingu. Sousel, segundo o autor "a última povoação habitada por brancos" na subida do rio Xingu, contava nessa época com 40 a 50 “cabanas de barro e ranchos abertos”. A população majoritária é caracterizada pelo autor sempre como de herança indígena, "mestiços dos habitantes primitivos e brancos". Nesse sentido nota-se ao longo do relato, a menção recorrente ao casamento com mulheres indígenas, ou com essa origem aparente. É em Sousel que o príncipe Adalberto agencia os meios para impetrar a desejada experiência no rio Xingu, pois encontra a orientação o Padre Torquato com sua experiência entre os indígenas da região. A comunicação entre os habitantes de Sousel, bem como com indígenas dessas áreas era feita por meio de língua geral.

Os índios selvagens, os quais o príncipe foi avisado de existirem no Xingu e que desejava encontrar, são mencionados no texto como sendo os Juruna ${ }^{13}$. Já em Sousel, o autor comenta sobre a ampla presença desses indígenas que iam integrando a expedição rio acima conforme esta ia passando pelas localidades a beira do rio. A descrição indica que, conforme se avançava na expedição, mais em estado genuinamente selvagem se apresentavam os indígenas, representados através de seus modos de vestimenta, hábitos alimentares, costumes de dança, tradições de sepultamento, estilos construtivos, histórias de caça e guerra, entre outros.

Seguindo o relato da viagem, a travessia pelo rio Xingu no trecho a partir de Sousel era considerada quase impossível devido a grande presença de corredeiras nesse trecho do rio (como anteriormente observado, conhecido como Volta Grande atualmente). Então uma estrada foi construída fazendo a ligação do igarapé Tucuruí até o Anauraí14. Essa estrada ligava o último entreposto do baixo rio Xingu ao início do médio Xingu, onde se encontravam as populações indígenas cujas experiências de contato não haviam ainda se firmado,

${ }^{13}$ Assim descreve Nimuendaju, no Handbook of South American Indians (1948), sobre os documentos dos Juruna visitados por Adalberto: "In 1843, the Yuruna, by that time completely tame, were visited by Prince Adalbert of Prussia, guided by Father Torquato. At that time they lived in nine small villages between Tauaquera and a point one hour above Piranhaquara. There was no village in Volta Grande, but the Yuruna paid friendly visits in Souzel and knew a little Tupi-Guarani. Father Torquato reported their number as 2.000, which would average 222 to each village; possibly 200 would come nearer to the truth" (NIMUENDAJU, p. 9, 1948).

${ }^{14}$ O igarapé Tucuruí se encontra atualmente na cidade de Vitória do Xingu, que se mantém como importante porto de ligação com a cidade de Altamira. É possível que o igarapé Anauraí seja o atual igarapé Altamira, ou mesmo o Ambé, que estão localizados a norte de Altamira, na chegada da atual rodovia que liga os dois municípios. 
determinando a ocupação civilizada de seus limites; conforme é explicado preciosamente no trecho a seguir do relato do Príncipe Adalberto:

"Já em meados do século anterior tinham os jesuítas fundado uma missão que,
por meio da Estrada entre Tucuruí e o Anauraí, ficou numa mais próxima
comunicação com Sousel, e a que chamaram Tavaquara (Tauaquera).
Infelizmente esta colônia durou pouco porque os últimos filhos de Loiola
incumbidos da catequese dos jurunas pagãos, devido aos seus maus costumes
que pouco harmonizavam com o seu talvez excessivo zelo de catequização,
depressa perderam a confiança dos indígenas e em consequência foram por
eles assassinados. Passou-se quase um século sem que fosse possível levar a
luz da fé além das cataratas, até que dois anos antes nosso amigo eclesiástico,
Padre Torquato Antônio de Sousa, apareceu nessa região no $1^{\circ}$ de novembro
de 1841 , levantando pela segunda vez, a cruz de Tavaquara, dando à nova
colônia o nome de Missão Imperatriz, e que pelo seu afável trato e larga
distribuição de tigelas de porcelana, contas e miçangas, ferramentas, etc., entre
os jurunas, que de tempos em tempos desciam até Sousel, atraía sempre mais
índios de sua aldeia para ela, conquistando cada vez mais sua confiança e
batizando-os". (ADALBERTO, p. 180, 1977)

Este pequeno trecho ganha uma importância fundamental na presente análise. Nele estão contidos elementos que, correlacionados às histórias ouvidas em campo dos antigos moradores de Altamira sobre os bairros estudados, apresentam interessantes aproximações e distanciamentos que fornecem uma base fundamental para as discussões acerca da história local propostas pela pesquisa. A lembrança do bairro chamado "Missão", cuja localização é fruto de controvérsias entre as versões contadas pelos interlocutores ouvidos na pesquisa, é um fato marcante do ponto de vista das histórias sobre a presença dos indígenas em Altamira. Atualmente com um número bastante grande de famílias que se autodeclaram indígenas espalhadas por diversos bairros da cidade, quando se pergunta sobre a história da formação de Altamira com especial atenção para seus habitantes indígenas, o ponto de intersecção decorre da existência do antigo bairro chamado Missão, envolvendo também a menção do bairro Muquiço, ambos localizados ao sul da região central de Altamira, entre o final da atual avenida da orla do rio Xingu, até a região do Igarapé Panelas, próximo à praia do Pajé.

As referências espaciais, apresentadas nos relatos ouvidos durante a pesquisa sobre a ocupação dos indígenas em Altamira trazem elementos recorrentes, que fundamentam a estreita ligação que esses habitantes tiveram com a formação da cidade. Contudo, essas histórias, sejam no relato do Príncipe Adalberto da Prússia, sejam nas trajetórias de vida levantadas pela pesquisa, mobilizam espaços para além dos bairros e da cidade, percorrendo 
relações através do rio por distâncias que podem durar dias ou até meses. Os modos como esses enunciados constroem as representações espaciais que preenchem as relações entre as pessoas é um componente fundamental para a compreensão da vida social entre os indígenas e não indígenas que habitaram e habitam a região de Altamira.

A descrição da paisagem, tanto humana quanto natural, ao longo do Rio Xingu apresentada pelo Príncipe Adalberto da Prússia é orientada pela tônica do ambiente selvagem. Dominado pela fantasia de infância de encontrar os selvagens da floresta, o príncipe parece misturar sua sensível acuidade em detalhar com considerável minúcia os episódios de sua viagem, com interpretações, que a despeito de não poderem ser consideradas inocentes como seu desejo infantil, mantêm-se circunscritas sob representações que se colam aos objetos reportados de modo claramente romantizado. É uma percepção bastante interessante para se pensar sobre as representações feitas sobre os povos não europeus nessa época, uma vez que a possível formação romântica do monarca alemão o fez ter simpatias particulares com pessoas que poderiam eventualmente ser classificadas como primitivas nos esquemas científicos evolucionistas em voga. Contudo mantém-se o ideário do ambiente inexplorado ocupado por homens selvagens. Aludindo ao modo como Peter Gow situa a carta de Euclides da Cunha em sua análise, é possível considerar que a simples afinidade do príncipe prussiano com o imperador Dom Pedro II não tenha determinado suas interpretações da viagem com as preocupações imediatas do Império. O privilégio desse relato, contudo, não o destitui de análise crítica que irá inferir diretamente nos sentidos observados nas histórias contadas pelos interlocutores da pesquisa, moradores atuais de Altamira. A descrição da viagem, e mais especificamente da Missão Tavaquara, atualmente onde se localiza a cidade de Altamira, embora carregue na densidade dramática do ambiente rústico, não deixa escapar a manutenção da organização indígena. A despeito dessa organização ser atribuída, pela explicação do príncipe, ao antigo estabelecimento da Missão de aldeamento indígena implementado pelos jesuítas que, por sua vez, foram expulsos durante a administração pombalina, ou então pela recente retomada do aldeamento sob os esforços do padre Torquato; o lapso de tempo entre as ocupações não indígenas, durante mais de cem anos, parece não ter trazido a automática extinção do aldeamento pelos indígenas da região ${ }^{15}$. Esse parece ser um

\footnotetext{
${ }^{15}$ Nimuendaju nos oferece a seguinte descrição desse período de ausência de fontes históricas sobre a região: "During the following 150 years, there is no record of the tribes above Volta Grande, which seem to have been left to themselves, protected by the dangerous falls and by their reputation as ferocious cannibals; as late as 1831, their attacks were feared above Souzel. In 1841, the Vicar of this village, Torquato Antonio de
} 
ponto fundamental para se compreender porque os indígenas atuais de Altamira ainda mencionam a existência desse local, obviamente, reposto em termos contemporâneos, cujos significados a etnografia pretende explorar. A princípio essa evidência induz a suposição de que essa organização indígena local poderia ser preexistente ao aldeamento jesuíta, um fato que encontra similares na história brasileira, mas torna-se, indelevelmente, objeto das reflexões acerca da história dessa região que a dissertação não será capaz de dar cabo. Contudo, a significância dessa possibilidade é um elemento que subjaz, de diversas maneiras, nos relatos históricos contados pelos moradores de Altamira, na forma de um discurso sobre a antecedência indígena no rio Xingu, mas também, na própria cidade de Altamira, e especificamente nos bairros hoje chamados de Jardim Independente e São Sebastião, todavia sempre relembrados como Missão e Muquiço.

Não é possível afirmar nem negar a familiaridade dos moradores entrevistados para pesquisa com as histórias da missão jesuíta. Para além de uma possível "manipulação" dos fatos históricos formadores da cidade de Altamira, pretende-se restituir, tanto pelo relato do Príncipe Adalberto da Prússia como pelas histórias contadas pelos moradores Xipaya e Kuruaya de Altamira, os fios da tessitura indígena na formação da cidade, que hoje repercutem nas especificidades das experiências dos indígenas citadinos. Essa ligação, como se verá, propõe uma interpretação histórica formulada em termos nativos, sem que a evidência das relações seja necessariamente verificável como causalidade cronológica imparcial, tal como uma posição de sobrevoo que organiza os fatos históricos neutralizados. Tomam-se, então, esses fragmentos sobre a memória da Missão, datados desde o século XVIII pelo príncipe Adalberto, mas que a visitou já em meados do século XIX, como momento anterior aos processos aos quais as lembranças dos contemporâneos Xipaya e Kuruaya de Altamira irão se remeter para a reconstrução das histórias sobre a Missão (Jd. Independente) e Muquiço (São Sebastião). Fazendo um levantamento das fontes sobre a migração Juruna no médio Xingu, Nimuendaju apresenta a seguinte situação desse grupo após a visita do príncipe, descrevendo as adversidades pelas quais passaram:

"In 1859, the Government of the Province of Para initiated again the catechization of the tribes above Volta Grande; however, the first attempt was a failure. At this time the number of Yuruna, in three villages, was calculated at 235. This mission was kept up until about 1880 , with, it seems, little success (...). When Von den Steinen descended the Xingu in 1884, this mission was

Souza, made a new attempt to establish a mission in Tauaquera, which, after a few years, seems to have been abandoned (NIMUENDAJU, p. 218, 1948)". 
no longer in existence. Two hundred and five Yuruna inhabited five villages between "Pedra Preta" (lat. $4^{\circ} 40^{\prime}$ S.), above Piranhaquara, and lat. 8' 30' S., a little below Pedra Seca. These Indians still maintained their independence, and their original culture was almost intact. The civilized population had not yet reached the mouth of the Iriri. When H. Coudreau visited the Xingu in 1896, the situation of the tribe was completely changed. The 150 Yuruna, except for a group which had fled a little beyond Carreira Comprida, had fallen into servitude to the rubber gatherers, whose authority was extended to above the mouth of the Triumph River. Another small group, led by Tuxáua Muratï, lived in Cachoeira Jurucua, in Volta Grande (...). Later, impelled by poverty and by the attacks of the Cayapo, part of them returned, but in 1916 they once more fled to the upper Xingu never to return (...). Probably there are also survivors in Volta Grande of Tuxáua Muratü's family". (NIMUENDAJU, p. 219, 1948).

Diferente do Príncipe Adalberto, Nimuendaju escreve como etnógrafo, preocupado com as informações disponíveis sobre os Juruna dessa região. Nesse aspecto suas informações tem o privilégio, para o presente estudo, de apresentar-se como colaboração alinhada à ideia de reconstituição da história indígena, por mais que se possam fazer hoje muitas reflexões sobre o estatuto do que seria essa história. Conquanto, se nos eventos destacados por Nimuendaju tem-se a situação de fuga dos Juruna da região ${ }^{16}$, que foi sistematicamente ocupada durante o primeiro ciclo da borracha (1879-1912), as versões Xipaya e Kuruaya sobre presença indígena em Altamira reconstituem outras migrações, cujas fontes são mais escassas:

"The Shipaya (lat. $5^{\circ}$ S., long. 55" W.) were first made known to civilization by the Jesuit priest, Roque Hundertpfund, who (in 1750?) went up the Xingu and the "River of the Jurunas" (Iriri), on a preaching tour of the Curibary (Curuaya) and Jacipoya (Shipaya). Whereas the Yuruna had for more than two centuries maintained themselves on a constant defensive against civilized people, the Shipaya had until after 1880 remained quietly in their own region without contacts with the civilized world. Kletke (1857), Brusque, and H. Coudreau mentioned them, but did not visit them. The first scientist to have direct and lengthy contact with them was Emilia Snethlage, in 1909, and especially in 1913" (NIMUENDAJU, p. 219, 1948).

\footnotetext{
${ }^{16}$ Esses são os episódios que deram origem a divisão entre os Juruna: o grupo que hoje habita o Parque Indígena do Xingu PIX e o grupo que habita a Volta Grande do Xingu.
} 
Mantendo o olhar sobre os bairros Muquiço e Missão, como espaços tradicionalmente ligados a presença Xipaya e Kuruaya em Altamira, é possível avançar sobre os relatos das trajetórias de vida de alguns moradores dos bairros a fim de iluminar novos pontos de vista sobre essas histórias registradas de Altamira Indígena. Tendo em mente que essa é uma história de poucos documentos oficiais, e aqueles existentes nem sempre fazem jus à contribuição dos indígenas, pretende-se um aceno para preencher essas histórias por meio das versões dos interlocutores, contudo mirando quais significados particulares essas histórias estão mobilizando nos contextos atuais. Como sugere a provocação de Maria Augusta Xipaya, relembrando a época em que trabalhava no asfaltamento da cidade e encontrava material arqueológico por toda Altamira:

"Disseram: 'Olha aí, os cacos de pote'. Disse: 'Caco de pote não! Isso aí não tem nada de caco de pote, isso aí é panela de índio!' Daí olhava os desenhos dos índios... Onde que eu pensei algum dia: vou pegar e vou guardar? Hoje era uma prova, não era? Um documento muito grande (...) Logo no começo, a Prelazia dizia assim: que a aldeia começava ali da casa da mãe do Gilson, para cima... agora já não é mais, agora é lá no Jardim Independente II pra lá. Agora estão falando isso né, eu disse: 'olha, negativo meu amigo! Eu que trabalhei na beira dessa caís, eu via os cacos de panela!' Eu nunca tive a ideia de guardar pra provar pra eles, mas Altamira é contaminada indígena!"

\subsection{Muquiço e Missão: histórias dos bairros indígenas em Altamira}

Como foi anteriormente apresentado, Peter Gow observa, em seu artigo "Canção Purus" (2005), os esquemas de tribalização operando na forma das canções piro, mais especificamente no gênero "canções de homens", que enigmaticamente, segundo o autor, são cantadas atualmente apenas por mulheres, mas que são canções que parecem "de fato documentar uma história no sentido piro". Contudo o autor salienta que entre os Piro, a produção do conhecimento histórico não decorre de uma imagem de conhecimento colecionador, o que significa dizer que, no limite, os Piro não são afeitos ao contar histórias, pelo menos ao nosso modo, com datas, lugares e pessoas claramente demarcados numa linearidade temporal. Essa evidência, recorrente para a etnologia americanista, é correlacionada por Gow com o fato das canções masculinas não estarem mais ativas entre os Piro: 
"O gênero era, pode-se dizer, muito e perigosamente histórico para os homens piro, trazendo o passado na forma de ciclos incompletos de rivalidade masculina. Não sendo mais ativamente compostas, essas canções sobrevivem apenas no discurso cantado de mulheres mais velhas". (GOW, p. 460, 2005).

Embora não atualizem mais o valor social Piro sobre ideais de masculinidade, essas canções - ainda cantadas por algumas mulheres - mantém sua densidade histórica, apresentando os modos da relação piro com o conhecimento do passado:

“A 'Canção Purus', ao contrário, é o que gostaria de chamar de tribalização. Ela toma de uma série de experiências vividas de sofrimento e a transforma numa sociável canção para beber. Experiências específicas de raiva, violência, vingança e perda são esvaziadas de seu conteúdo emocional para pessoas particulares, e são generalizadas em uma canção absurda sobre uma emoção absurda". (GOW, p. 460, 2005).

As meditações de Peter Gow sobre o conhecimento histórico Piro infletem na presente pesquisa sobre as possibilidades da etnografia de lidar com os objetos históricos entre seus interlocutores. Fruto do interesse da pesquisa, a investigação histórica estaria autorizada a induzir os meios pelos quais serão "coletados" os dados etno-históricos? Significa denunciar o desconforto do pesquisador com os conceitos metodológicos de memórias e trajetórias de vida mobilizados para realização da pesquisa. Ao mesmo tempo em que essa reserva traz consigo não apenas possíveis problemas da transposição analítica, mas sugere uma transformação efetiva do campo de análise. Evidentemente Peter Gow está lidando com formas "tradicionais" de conhecimento, nomenclatura estabelecida por nossa tentativa de classificação de outros modos cognoscíveis. E o fato de serem "formas" distintas de apresentação de um possível modo de falar sobre história entre os Piro determina efetivamente as conclusões do autor. Não se pretende aqui lamentar a ausência dessa forma distinta clara entre os interlocutores da pesquisa, revelando sua distância dos contextos analisados por Peter Gow. Embora essa distância seja evidente, é possível recuperar nos argumentos de Gow a inspiração para não recairmos no esquema automático classificatório de outros modos de conhecer: canções podem ser consideradas conhecimentos tradicionais, desde que essa classificação não preceda o modo piro de concebê-las. Da mesma forma, a preocupação desse estudo no sentido da investigação histórica dos bairros por meio de memórias e trajetórias de vida, não é anterior ao modo como essas histórias são contadas e sentidas pelos interlocutores da pesquisa. Esse movimento, de atenção ao específico para ascensão ao geral, constitui-se na proposta analítica que será empreendida a seguir com a apresentação dos relatos e entrevistas realizados em campo. Mais uma vez, pretende-se 
correlacionar essas histórias aos processos de ocupação e desenvolvimento da região, mantendo-se as perspectivas das relações entre indígenas e não indígenas moradores da cidade de Altamira, como uma proposta etnográfica para se pensar história, inspirada nas sugestões de Peter Gow.

O bairro do Muquiço firmou-se como o ponto de emanação para a etnografia, desdobrando questões para além de suas fronteiras espaciais, que por sua vez lidam com as práticas e discursos particulares a produção da vida social dos moradores Xipaya e Kuruaya de Altamira. A fundamental eleição do bairro como certo ponto de partida para a etnografia ecoa nas diversas abordagens que se tornaram necessárias com o desenvolvimento da pesquisa, permitindo uma melhor compreensão de todas as inflexões produzidas no atual contexto de significativas transformações sociais trazidas no bojo de Belo Monte.

Objeto de discussão nas entrevistas realizadas em campo, o bairro foi abordado através dos relatos daqueles que o construíram ou foram moradores no início de sua construção. Como dito, esse foi o momento em que a pesquisa ganhou tons de uma investigação histórica, deslocando-se entre as versões enunciadas pelos interlocutores. Essas versões caracterizam-se como produtos de uma complexa rede de significação que lida com referências de parentesco, vizinhança e amizade, operadores fundamentais das relações entre os indígenas e não indígenas de Altamira, infletindo nas questões políticas da cidade e região. Essas "dimensões" da etnografia serão analisadas nos capítulos seguintes da dissertação. Por ora, será mantida a ênfase nos aspectos históricos da formação de Altamira e dos bairros, perseguindo as relações que se estabelecem entre a percepção da Missão e a identificação dos indígenas em Altamira nas suas diversas épocas. A abordagem pretende não apenas compreender como é possível pensar as temporalidades produzidas nesses discursos históricos e suas relações com as práticas e discursos contemporâneos da vida social entre indígenas e não indígenas de Altamira, como também supõe que os modos como essas histórias relacionam-se a territorialidades remete à consideração de como a construção dos espaços de interação e conflitos na cidade e região é fator decisivo nos processos de transformações sociais existentes no presente e no passado dessas histórias. 
A interface colocada entre o pesquisador e os interlocutores da pesquisa, como foi dito, era a importância histórica do bairro Muquiço (São Sebastião), da contribuição dos indígenas na sua construção e na consequente história de Altamira. Dessa abordagem, seguiram-se as descrições pelos interlocutores da pesquisa de suas trajetórias pessoais desde a chegada ao bairro, caracterizando suas edificações, número de moradores, acessos à cidade e as relações com o centro de Altamira, atividades desenvolvidas pelos moradores, festas e manifestações que ocorriam no bairro ou através de seus moradores, bem como episódios pessoais que transcorreram nesse espaço, como casamentos, mortes, eventos de caráter significativo para os enunciadores dessas histórias.

Cumpre notar que meu acesso inicial ao bairro se deu pelo morador não indígena Francisco, conhecido mais como Chico Tatu, casado com uma indígena Xipaya chamada Francisca. Nascido em Ipaumirim no Ceará, Chico Tatu conta sobre a relação com Altamira quando de sua primeira vinda em 1951, ainda criança junto de seu pai. Os motivos pelos quais o pai decidiu migrar estão principalmente ligados a oportunidades de trabalho e obtenção de terras, uma condição amplamente destacada em muitos relatos de migrantes. Essas justificativas repousam nas explicações sobre a necessidade da migração devido ao fato de os estados de origem, principalmente aqueles da região do Nordeste do Brasil, serem caracterizados como lugares em que não existia a oportunidade de ascensão econômica, traduzida pela exigência do trabalho nas terras de alguém e impossibilidade de aquisição das suas próprias. Nas palavras de Chico Tatu que refletem a de muitos outros migrantes, "Quem tinha terra, tinha; quem não tinha, nunca iria conseguir". Desse discurso então decorre um elemento constante nos processos de ocupação dos territórios amazônicos em geral, promovidos pela propaganda e projetos de estado, mas também, é possível conceber, produtivos no imaginário social dos migrantes. A ideia, de consequências tragicamente materiais, da "terra sem homens, para homens sem terra" na Amazônia é a condensação de um processo longínquo, que remonta não apenas às intenções integracionistas e desenvolvimentistas do governo militar brasileiro, mas também se liga às pequenas trajetórias individuais de aventuras e conquistas fundamentadas pelas perspectivas de transformação e melhoria de vida. Conforme Chico Tatu conta, seu pai estava vindo porque se cansara do "sistema de meia" ao qual estava sujeito no trabalho nas terras do engenho, em que tudo que era plantado ou feito deveria ser dividido com o patrão. Chico Tatu destaca como para aqueles que queriam deixar o trabalho no engenho era necessário "fugir" do patrão que não aceitava a 
saída dos trabalhadores. Nesse sentido, conta-nos um episódio fundamental para a partida de seu pai:

"Uma vez meu pai se injuriou, porque mamãe estava com o bucho nas goelas, e quando o milho estava maduro ele foi lá e tirou seis espigas de milho, botou numa tira e vinha no cabo da foice... Quando o patrão encontrou no caminho e disse 'mas compadre, e esse milho, você não sabe que esse milho é de meia?' 'Não mas a mulher está desejando...' 'Mas o senhor pode ir lá e tirar as mesmas seis espigas que eu vou levando aqui esse, o senhor pode ir lá e tirar...' Papai se injuriou dessa época... E papai ainda disse pra mamãe: 'olha, eu vou me embora do Ceará, mas se eu morrer no Pará e minha alma tiver vergonha, no Ceará ela não pisa mais!".

Assim decorre a primeira ida da família de Chico Tatu para o Pará, na região do Rio Xingu, através de uma intermediadora chamada Francisquinha, que organizou e financiou a viagem com destino aos seringais de Anfrísio Nunes no Alto Xingu, uma situação, como Chico Tatu brinca, em que eles vieram "vendidos". Contudo dessa primeira ida aos seringais, sua mãe não se acostumou com a vida no alto, e o flagelo da malária fez com que decidisse retornar com os filhos, incluindo Chico Tatu ainda criança, para o Ceará, deixando para trás o marido.

Chico Tatu conta como, mesmo voltando ainda criança para o Ceará, sempre manteve o sonho de reencontrar o pai no Pará. Nesse meio tempo casou-se e cuidou da mãe enquanto seu pai e irmãos mais velhos os sustentavam mandando dinheiro do Pará. Uma das histórias que Chico Tatu conta, antes da volta ao Pará, é sobre sua passagem por São Paulo vindo ainda jovem junto de seu tio. Chico Tatu lembra que essas eram as opções que se abriam ao sonho migrante da mudança de vida, a migração para os estados na Amazônia, ou para o sul do país, principalmente São Paulo e Paraná. É curioso notar, mais uma vez, as correlações entre imaginário do migrante nordestino e as formas em que se deram os desenvolvimentos brasileiros, em que São Paulo figura também como terra das oportunidades, porém do trabalho assalariado, incialmente rural, mas preponderantemente urbano conectado ao crescimento das cidades e desenvolvimento industrial nessa região. Podemos parafrasear jocosamente o jargão setentista da Amazônia para São Paulo, dizendo "um lugar de trabalho sem homens trabalhadores, para homens trabalhadores sem lugar de trabalho". Obviamente a ironia peca pela estereotipação, mas alguns elementos desses imaginários que produziam e 
eram capturados por movimentos de transformações sociais são decisivos na percepção da constituição das relações entre grupos estabelecidas no contexto atual. É nesse sentido que se destacam, para o caso da ocupação de Altamira, as formas em que as expectativas dos migrantes, aqui principalmente os nordestinos vindos durante o segundo ciclo da borracha (1942-1945), os famosos arigós dos relatos nativos, encontravam-se com as situações locais e os habitantes paraenses de diversas origens e indígenas. Se a caricatura brinca com o slogan amazônico lançando mão da ideia de "um lugar onde se encontra trabalho", que por sua vez tem correspondências com as transformações socioeconômicas e culturais que caracterizavam esses períodos de intensa migração para São Paulo, ela tem o sentido de contraste com o caso de Altamira, e da região amazônica em geral. Pois os efeitos da ideia de "um lugar onde se encontra terras", mesmo quando ainda a distribuição de terras não era uma propaganda e projeto de Estado, produziram outras transformações socioeconômicas e culturais correspondentes aos períodos de migração por ocorrência da exploração da borracha e da posterior colonização pela implementação da rodovia Transamazônica. Se hoje vemos a questão fundiária como um problema intransponível na política regional não apenas indígena, mas em geral, ela encontra vestígios nesse passado recente da história de Altamira. A mobilização dos migrantes nordestinos na extração da seringa, principalmente nas regiões do médio rio Xingu e seus afluentes, como o rio Iriri e Curuá, ao lado das expectativas gerais desses migrantes com relação à obtenção de terras, compõem ingredientes de "pontos de vista" migrantes. Essas "versões", por sua vez, indicam elementos de reflexão fundamentais para se pensar a formação dos processos que levaram as situações indígenas na cidade de Altamira, tanto no passado como atuais.

Embora a exploração econômica da atividade seringueira tenha sido o deflagrador dos movimentos migratórios para região, concentrando populações principalmente nas regiões do médio rio Xingu e seus afluentes, como os rios Iriri e Curuá, a cidade de Altamira cumpria, desde essa época, a função de entreposto para as viagens rio acima. Já conhecida por se tratar de uma localidade de aldeamento de indígenas da região, durante o segundo ciclo da borracha guardava fundamental papel na economia da região, caracterizado pela atividade comercial de apoio ao trabalho de extração da seringa. Abrigava alguns importantes comerciantes que distribuíam suas mercadorias entre os regatões, que consistiam em intermediadores que levavam mercadorias aos seringueiros, muitas vezes praticando preços abusivos nas localidades do rio, onde não se tinha outro acesso a esses bens. Como comenta Chico Tatu, 
que teve comércio em Altamira, vendia uma lata de leite por cinquenta centavos na cidade, que chegava a ser vendida a 15 contos no alto.

As memórias de acesso mais longínquo no tempo, que são possíveis de serem ouvidas nos relatos dos interlocutores da pesquisa, estão localizadas nesse período em que o comércio da borracha era o principal agente da vida econômica local, e assim também compreendeu em importante vetor das transformações sociais da região. Nessa época Altamira ainda era pouco povoada, sendo as localidades ao longo do rio bem mais habitadas do que são hoje, como se revelam em alguns relatos. Contudo alguns bairros de Altamira já se encontravam mais povoados, como é o caso da região dos bairros atuais, São Sebastião e Jardim Independente, regiões que abrigavam os antigos bairros do Muquiço e Missão. Nesse sentido o relato de Chico Tatu revela:

"Até um dia desses era Muquiço isso aqui. Aí tinha os caboco... tinha Taripü com a família dele, era o chefe daqui. Quando eu cheguei aqui, isso aqui, de lá onde é a pracinha hoje, perto da universidade, da FUNAI; lá tinha uma mangueirona grande, que era do Zé Bulamarque, o primeiro prefeito aqui. Aí botou um mosaico... tinha o Piancó, que trabalhava com mosaico, que era tipo uma cerâmica que eles faziam. De lá até aqui o Zé Bulamarque respeitava; ele que era o chefão, filho do Coronel José Porfírio, aí respeita a Missão; que aqui era dos 'cabocos', dessa área até lá no Igarapé Panelas, essa área era da Missão".

A área dos "cabocos", como são referidos os indígenas de Altamira, principalmente de origem Xipaya, Kuruaya e Juruna, era reconhecida geralmente como Missão, e estava localizada ao sul da região central da cidade de Altamira. Remontando à antiga ocupação de aldeamento iniciada pelos padres jesuítas, os bairros dessa região de Altamira ainda são lembrados pela tradicional residência dos indígenas, que ao longo do tempo coabitaram com não indígenas e também se dispersaram por outros bairros da cidade. Como sugerem os documentos históricos ${ }^{17}$, tratava-se de uma povoação quase exclusivamente habitada por indígenas, ao que parece principalmente pelos Juruna, mas também posteriormente pelos Xipaya e Kuruaya que mudavam para a cidade, sendo que, embora não seja possível determinar exatamente os períodos principais em que ocorreram as mudanças desses indígenas, é possível vislumbrar, na correlação dos relatos que serão apresentados no decorrer

\footnotetext{
${ }^{17}$ Como os relatos de viagem do Príncipe Adalbert (1977), por exemplo.
} 
do texto, que se tratavam de períodos próximos aos das grandes migrações por conta da exploração da borracha. Assim, embora a Missão seja considerada um local originalmente indígena, traduzido pela história do aldeamento como fundador da cidade de Altamira, podemos notar nos relatos das trajetórias de vida daqueles que constituíram essa história local, momentos de significativas transformações sociais pelas quais passaram esses grupos indígenas, e que irão constituir as particularidades da situação desses moradores da cidade. Portanto alguns aspectos do contato são fundamentais para a compreensão desses particulares. O contato interétnico, por sua vez, propõe à etnografia uma abordagem multifocada nas diferentes perspectivas daqueles que o produzem e produziram, principalmente porque relaciona trajetórias pessoais, caracterizadas como escolhas baseadas em expectativas e vontades individuais, mas também que se produzem a partir de encontros e conflitos entre culturas, envolvendo repertórios que são impelidos a transformações nessas novas conjunturas impostas. O teor das relações de vizinhança e amizade no espaço do bairro e da cidade é exemplificado de maneira bastante divertida nas palavras de Chico Tatu:

“Aí, como foi que eu abracei as indiarada? Foi tocando! Tinha o finado Frederico... Aí nós tocávamos sanfona e 'bora fazer uma festa aqui, bora!' Aí a cabocada tudo, cunhãzinha tudo bonitinha dançando... Animei, animei e pronto! 'Chico Tatu vem tal dia... e bora fazer a festa!' Fazia lá, fazia aqui na cabocada... dai pronto! Fui animando a turma, dai arranjei amizade com os caboco".

A menção às festas que ocorriam no bairro é um ponto de convergência bastante interessante de relatos dos antigos moradores dessa área. Assim se percebe nas palavras de Maria Kuruaya, moradora do bairro desde os seus 15 anos de idade e casada com José Mineiro "Caneco" Kayapó. Nascida por volta do ano de 1951 na localidade de Bonfim, no alto rio Xingu e Iriri, uma povoação de seringueiros; seus pais, Paulo Kuruaya e Maria Akarirá mudaram-se para Altamira quando Maria ainda tinha 12 anos de idade, vindos a convite do tio, Frederico Kuruaya, morador da região onde hoje se encontra o cais na orla central de Altamira. Conhecidos por muitos dos indígenas moradores da cidade de Altamira, Paulinho e Akarirá, como eram chamados, são importantes referências para as tradições dos Kuruaya na cidade, muito considerados ainda hoje nos relatos daqueles que sentem saudades das épocas em que os costumes Kuruaya eram preservados e para aqueles que desejam 
fortalecer as identidades indígenas na cidade. A festa do kariá ${ }^{18}$, tradição de dança e canto que imiscui as heranças Xipaya e Kuruaya em Altamira, é uma das recorrentes lembranças presentes em muitas histórias contadas, e que frequentemente remete-se à contribuição dos pais de Maria, já falecidos. A própria lembra-se com emoção do tempo em que os pais eram vivos e realizavam a festa:

"Quando mamãe era viva, mais o pai, cantavam e dançavam o kariá. Chegavam esses índios Kayapó, achavam bonito e ai diziam pra ela 'canta aquela cantiga de Kuruaya' aí mãe cantava, dançava e eles começavam a dançar. Os índios chegavam, pegavam na mão do pai; o pai era muito alegre. Gostavam muito de papai os índios Kayapó, Deus o livre gostavam demais! Toda noite ele dançava o kariá."

A festa do kariá não é mais realizada, mesmo recebendo a atenção atual daqueles que atuam nas associações dos indígenas citadinos de Altamira interessados nas manifestações culturais de seu passado e sendo relembrada em alguns momentos especiais por aqueles que ainda guardam as memórias das cantigas ou por aqueles que aprenderam com os pais e avós e hoje contam aos filhos e netos. Maria não chegou a aprender a cantar e a dançar com os pais, conforme relata, contudo cita Maria Yawaidu, sua cunhada, casada com seu irmão Nãe já falecido, como uma das pessoas que, juntamente com os seus pais, realizavam o kariá. Atualmente Maria Yawaidu é a única Xipaya ainda fluente na língua e também com grande entendimento da língua Kuruaya. Como visto, era uma festa que congregava os Xipaya e os Kuruaya e que remonta aos períodos de coabitação e convivência nas localidades do alto, como se referem quando falam do tempo em moravam nas áreas do rio Iriri e rio Curuá, ainda no tempo da extração da borracha e durante o avanço e conflitos com os Kayapó. Nesse sentido, não deixa de ser particular a íntima relação do pai de Maria com os Kayapó que, segundo a mesma, chegavam das aldeias e ficavam alojados no SPI, atual FUNAI, durante sua permanência em Altamira, indo ao bairro vizinho para participar das festas. Da mesma

\footnotetext{
${ }^{18}$ Nimuendaju (1981) fala do iánãi kariá, dança dos espíritos Xipaya, a qual observou pessoalmente em 1918, na foz do Igarapé Baú, no rio Curuá: "Os iánãi gostam, de vez em quando, de voltar ao meio dos vivos, para com eles dançar, beber e cantar (...)" (NIMUENDAJU, p. 32, 1981). Segundo sua descrição as festas eram realizadas apenas a noite e duravam mais de oito dias, o caxiri era preparado nos dias anteriores, bem como os apetrechos de dança e instrumentos musicais, sendo o pajé figura central na realização da festa. Embora a festa do kariá mantenha-se presente nas lembranças entre os interlocutores da pesquisa, não foi possível investigar quais ligações o kariá que era realizado na cidade manteria com o iánãi kariá descrito por Nimuendaju (1948;1981).
} 
forma assistiam os moradores não indígenas do bairro e das redondezas, embora nem todos participassem diretamente, frequentavam as festas oferecidas pelos pais de Maria, que ocorriam, segundo a mesma, na frente de sua casa, onde até hoje reside.

Da época em que mudou para o bairro, Maria destaca que seus vizinhos eram "duas famílias cristãs" mais a família de Taripü, já falecido Xipaya lembrado por Chico Tatu como chefe do bairro e pai de sua sogra atual. Desde que se mudou para o Muquiço (São Sebastião) até hoje Maria ressalta que o bairro sempre foi coabitado por indígenas e não indígenas, o que na sua visão, indica um problema nas versões que reivindicam esse bairro como sendo o antigo espaço da Missão, a chamada Aldeinha de Altamira: “(...) Aqui era misturado. Por isso que eu digo, a Missão não era aqui, era ali em cima. Lá que moravam os índios mesmo. Ali que é a Aldeinha, onde é o Independente”.

No antigo bairro da Missão ou Aldeinha (hoje Jardim Independente) que é próximo da região do Muquiço (que hoje é bairro São Sebastião localizado dentro do bairro Esplanada ${ }^{19}$ ) ainda vivem muitas famílias Xipaya e Kuruaya. Maria indica que as antigas famílias indígenas que lá habitavam e eram parentes seus não residem mais lá. Segundo Maria e Caneco, a região desse bairro é indicada como sendo a área aonde os "índios que vieram do alto" se estabeleceram. Nesse sentido é importante notar, conforme foi indicado anteriormente, que essas histórias contadas pelos Xipaya e Kuruaya sempre falam do nascimento dos pais e avós nos rios Iriri e Curuá, e sua migração para residência em Altamira, na época dos conflitos contra os Kayapó durante as atividades de extração da seringa. Assim, a Missão é relacionada a esse período e essas trajetórias, algo que não pode ser sobreposto imediatamente aos documentos históricos analisados, como o relato de viagem do Príncipe Adalberto da Prússia, que falam da existência da missão jesuíta Tavaquara entre os Juruna ${ }^{20}$, anteriores a esses episódios históricos. Esse, a primeira vista, descompasso sobre a ocupação do bairro da Missão sugere alguns fios da histórica presença indígena em Altamira que podem relacionar-se a predominância dos antigos Juruna na região atual da cidade até o primeiro ciclo de exploração da borracha na região, que data do final do século XIX, depois da ida do Príncipe Adalberto da Prússia, quando o aldeamento ganharia novo fôlego. Esse ciclo, por sua vez desencadeou o primeiro movimento de ocupação sistemática por não indígenas em Altamira, contudo a cidade mantinha-se como entreposto daqueles que empreendiam as

\footnotetext{
${ }^{19}$ As diferentes nomenclaturas dos bairros, oficiais e usadas pelos moradores, serão situadas com maior precisão no capítulo III.

20 As histórias contadas pelos Juruna residentes na cidade de Altamira falam de outras migrações ligadas, geralmente, a residência na Volta Grande do Xingu.
} 
viagens aos seringais ao longo do médio rio Xingu e seus afluentes, principalmente o rio Iriri. Esse é o período em que se consolidaram os contatos com os grupos Xipaya, falantes de língua Tupi da família Juruna, e os Kuruaya, falantes da língua Tupi da família Munduruku. As proximidades entre os Xipaya e os Juruna são sugeridas em alguns relatos dos atuais moradores indígenas de Altamira, contudo versam mais sobre o parentesco linguístico do que sobre as relações históricas ou míticas ${ }^{21}$. De qualquer maneira, é necessário compreender como os diversos momentos e características das migrações indígenas para a cidade de Altamira estão estreitamente ligados aos vetores de ocupação dessa região, e ao mesmo tempo como as relações entre os grupos indígenas e também com não indígenas se estendem até a região do alto.

Nesse sentido, as referências ao processo de migração relacionado à atividade seringueira durante os dois ciclos - no final do século XIX e durante a II Guerra Mundial -, ao lado dos conflitos com os Kayapó no alto são elementos fundamentais nas histórias contadas sobre Altamira, tanto por indígenas como não indígenas. Embora se tenha optado no momento por centrar-se nas construções que os relatos operam em torno da formação da cidade de Altamira, destaca-se que os aspectos particulares desses episódios localizados fora desse espaço urbano, que são evidenciados por cada discurso, serão retomados a frente.

Retomando os relatos de Caneco e Maria, estes revelam que as antigas famílias que residiam na Missão, principalmente os Xipaya e os Kuruaya segundos os relatos, foram sistematicamente saindo da área quando a família Milico, grandes comerciantes da região, interessou-se pela área. Também nesse sentido observam-se diferenças nos relatos no que diz respeito às formas em que se deram os processos de aquisição das terras e casas dos indígenas dessa região, ressaltando ora a inabilidade dos indígenas em lidar com o dinheiro, o que os impelia a fazer maus negócios de venda, mas também indicando a má fé, ou mesmo coação que muitas famílias passaram para saírem dessa área. O interesse da família Milico pela área estava ligado ao declínio da atividade seringueira e ascensão do comércio de peles, onde a área do bairro ficou conhecida por manter jaulas com os animais presos, mudando seu nome para bairro das Onças, como ficou conhecido na época.

\footnotetext{
${ }^{21}$ Nimuendaju oferece uma série de elementos para pensar essa proximidade, por meio dos dados etnográficos que coletou quando de sua visita à região (parentescos que iam do xamanismo aos costumes alimentares): "Physically, culturally, and linguistically, the Shipaya are the closest relatives of the Yuruna, being in many respects indistinguishable" (NIMUENDAJU, p. 219, 1948).
} 
Moradora atual do bairro Independente, Nazaré Xipaya nasceu no alto, num local chamado Bem Bom, seringal da família Meireles. Seu pai, o Xipaya Taripü, depois de trabalhar como seringueiro, foi renomado piloto de barcos, famoso por conhecer todas as corredeiras e rápidos do rio Xingu e afluentes. Conforme Nazaré indica, o pai foi morar no Muquiço (São Sebastião) em Altamira, por conta do avanço dos Kayapó no Xingu, e quando se tornou piloto, passava mais tempo no rio do que na cidade. O relato de Nazaré indica toda a área que ia desde onde se encontra atualmente a UFPA até o Igarapé Panelas como habitada pelos índios:

“Esse pedaço aqui era tudo só de 'caboco'. A roça era aqui pra trás tudinho (parte de onde hoje é o Jd. Independente I) e as casas eram na beira (do rio Xingu). Tinha tudo misturado, Xipaya e Kuruaya... cristão que morou por aqui era o falecido marido da dona Eneida, que morava bem ali. Era conhecida velha da gente, os maridos e os filhos."

Sobre a dispersão dos indígenas que habitavam a região, Nazaré também relata a aquisição das casas e terrenos pelo pessoal da família Milico. Situação curiosa, com relação a sua consideração sobre o modo muitas vezes injusto em que foram feitas essas aquisições, Nazaré relata que sua casa foi cedida por seu sobrinho Raimundo, filho de sua irmã Sebastiana, casada com João Milu, um dos irmãos pertencentes à família Milico.

O processo de transformação do bairro Missão, ou Aldeinha, como era chamado, para o bairro das Onças, quando muitos Xipaya e Kuruaya que ali residiam venderam suas casas e terras, é lembrado também por Maria Yawaidu Xipaya, que mantém residência dupla hoje em dia, no bairro e na aldeia Cojubim, antigo local de residência de seus pais Manuel Bitatá Xipaya e Kiripoco Kuruaya, atualmente localizada dentro da Terra Indígena Arara da Cachoeira Seca. Maria Yawaidu nasceu na localidade do rio Baú, afluente do rio Curuá, conhecida por ter sido uma grande aldeia que abrigou os Xipaya e Kuruaya que fugiam dos Kayapó, e também recebia os seringueiros que migravam para a região. Depois de casada, com seu falecido marido, o Kuruaya Nãe, mudou-se para Altamira, quando se lembra de ouvir sobre a história da Missão, onde moravam os cabocos Xipaya e Kuruaya. Lembra-se de alguns dos nomes dos antigos moradores que habitavam a região antes da transformação do bairro com a aquisição das terras pela família Milico: família do Bibicó Kuruaya (parentes da mãe de Maria) e sua mulher Antônia U'riá, Xipaya; Mariano Caboco e sua mulher Tereza A’yumã, ambos Xipaya; Taipá, que era pai do Pombo citado por Maria Kuruaya, também Kuruaya, com sua mulher Xipaya Na'mãen; Pi'ãndê Xipaya, também chamado João; Aricafu 
e Painaré, irmãos de Akarirá. Todos esses são nomes lembrados em diversos relatos daqueles que conhecem a história da Missão, referindo-se ao antigo bairro, que Maria Yawaidu reafirmou ser constituído pelas famílias vindas sempre do alto.

Embora mantenha sua casa atual no bairro Independente, vizinha de Nazaré Xipaya, desde que seu marido comprou o terreno da família Milico, revelou que sua primeira residência em Altamira foi no bairro Muquiço. O terreno adquirido nesse local foi dado pelo prefeito na época, por volta dos anos 1960, chamado Frizan Nunes, filho do conhecido seringalista Anfrísio Nunes com uma Xipaya. Reafirmou que o bairro do Muquiço não era a região considerada Missão, indicando apenas alguns moradores nessa área quando mudou para local: as famílias não indígenas de Maria Vilaça e Chico Tatu e as famílias indígenas de Paulo Kuruaya, pai de seu marido, e Taripü Xipaya. Relata que o local era pouco habitado na época, mantendo ainda muito mato virgem que dificultava o acesso ao centro da cidade. Sobre o nome Muquiço revela:

"Fui eu que botei esse Muquiço! É, não foram os outros não, fui eu. A gente queria andar, aí eu dizia 'vou lá pra rua'. Aí eu ia devagarzinho no caminhozinho... Aí o pessoal perguntava 'onde a senhora mora?' eu dizia: 'eu moro lá naquele Muquiço!' Que era cerrado... era cerrado demais lá! Aí os outros diziam 'lá onde dona Maria chama Muquiço...' aí foi indo, foi indo, pronto, acabou tudinho, todo mundo chamava de Muquiço. Antes de eu vim morar não tinha nome dizia... só morava o Taripü com a família dele daí dizia: 'onde que vocês moram? Lá onde é a casa do Taripü (...). Aí eu baixei de lá do alto, aí foi pra morar lá. Aí Frizan (seringalista e prefeito de mãe Xipaya) me deu terreno, aí queimei tudo direitinho; disse: 'aqui não vai ter bicho perto de mim não! (risos) E toca fogo né? Daí fica limpinho, até pra beira do rio... ai eu digo: 'é por isso que eu chamo aqui Muquiço!' Aí o finado meu marido, ele dizia: 'parece que vai ficar mesmo esse nome. Muquiço mesmo...' E ficou!'.

Para uma experimentação das possibilidades de análise dos conteúdos apresentados nesses relatos, é importante retomar novamente a maneira como esses enunciados estão vinculados ao interesse declarado da abordagem da pesquisa, relembrando: perseguir, a partir das memórias e trajetórias contadas, aspectos históricos da presença indígena na constituição desses bairros e da cidade de Altamira. Embora não seja possível obter uma resposta antes de 
realizar uma pergunta, é notável que antropologia e o método etnográfico, e por que não de modo geral o espírito científico, permitam ou mesmo exijam que suas questões se transformem em conjunto com as questões apresentadas por seus “objetos". Os modos em que a presença indígena é revelada nos relatos colhidos em campo são fundamentais para o desenvolvimento das reflexões da pesquisa. Preocupada, incialmente, em traçar os elementos da contribuição indígena para constituição dos bairros e de Altamira, é possível indicar que esse interesse imediatamente se torna problemático para a pesquisa ao observarmos que as histórias dessa ligação dos indígenas com a cidade são sempre mediadas por processos de espacialização que se transformam ao longo do tempo: significa dizer que os relatos estão sempre se remetendo a deslocamentos que transcendem a determinação dos limites da cidade, sendo que o lugar dos bairros e da cidade de Altamira nesses enunciados acompanham as transformações dos sentidos atribuídos a esses deslocamentos. Para além de afirmar que se trata de um recorte empírico limitado, cuja eleição apresentou muito mais um ponto de emanação para pesquisa do que um objeto fixo, conforme foi apresentado anteriormente, essas informações apresentadas nos relatos ouvidos permitem compreender que traduzir as contribuições das populações indígenas no contexto da formação de Altamira, a partir do que pode ser considerado como pontos de vista indígenas, implica refazer o modo pelo qual pensamos esses bairros ou a própria cidade.

A análise seguirá perseguindo o modo pelo qual são apresentados os processos de migração e deslocamentos em geral contidos nas histórias contadas pelos interlocutores da pesquisa, ao lado de outros documentos que revelam a densidade desses fenômenos entre os Xipaya e Kuruaya dessa região, na sua relação com não indígenas no processo de ocupação e constituição de Altamira. Esse modo de contar é um espaço de criação e possibilidades, caracterizado pelos interlocutores por meio dos desafios que marcaram a história desses grupos e daqueles novos que se delineiam em seu horizonte próximo.

\section{4 “Lá no alto" - histórias Xipaya e Kuruaya nos rios Iriri e Curuá}

A maior parte dos relatos de trajetórias de vida dos antigos moradores indígenas da cidade de Altamira remete-se a episódios da vinda para residência na cidade, seja ela a história pessoal ou de seus parentes próximos. Majoritariamente, os Xipaya e Kuruaya da cidade contam suas histórias relatando os deslocamentos oriundos das distantes regiões 
localizadas entre os rios Iriri e Curuá (afluentes na região do médio Xingu) e seus afluentes, como rio Baú e Curuaés. A extensa região foi marcada por deslocamentos de vários grupos indígenas e pela ocupação derivada da atividade de extração de seringa durante os dois ciclos de exploração econômica da borracha no Brasil, ao final do século XIX e início do século XX, e na década de 1940 durante a Segunda Guerra Mundial. Boa parte dos relatos localiza nesse segundo período as migrações para cidade, embora as motivações do deslocamento para os Xipaya e Kuruaya sejam sempre contadas pelo conflito e avanço dos Kayapó sobre suas aldeias. Assim é possível observar nos relatos, como foi indicado anteriormente, que existe um curso histórico específico para a situação dos Xipaya e Kuruaya na formação da cidade de Altamira. A aproximação entre os grupos Xipaya e Kuruaya é anterior ao movimento para cidade, contudo o sentido único que hoje é possível depreender da história desses dois grupos parece ter sua gênese localizada exatamente durante o período ao qual se reportam os relatos sobre os motivos da migração de ambos os grupos para cidade: durante o segundo ciclo da borracha por conta dos confrontos com os Kayapó. Nimuendaju (1948) cita rapidamente a trajetória Xipaya nos rios Iriri e Curuá, os conflitos contra os Kayapó e seringueiros que avançavam sobre suas áreas:

"From remote times the Shipaya inhabited the islands of the Iriri River, from the mouth of the Curuá downstream. They never settled farther up, for fear of Cayapó attacks. Later, about 1885, the Cayapó forced them to evacuate their settlements at the great falls of the Iriri, between lat. $4^{\circ} 50^{\prime}$ and $5^{\circ} \mathrm{S}$. and to take shelter in the Curuá, settling in the Gorgulho do Barbado, which they only temporarily abandoned in 1913, after a bloody encounter with the rubber tappers. Since then they have always been divided into two local groups: on the lower Iriri and on the Curuá". (NIMUENDAJU, p. 220, 1948).

O recorte regional do "Mapa Etno-histórico do Brasil e regiões adjacentes" (FIBGE), adaptado de Nimuendaju (1944), ilustra bem as migrações registradas pelo etnográfico: 


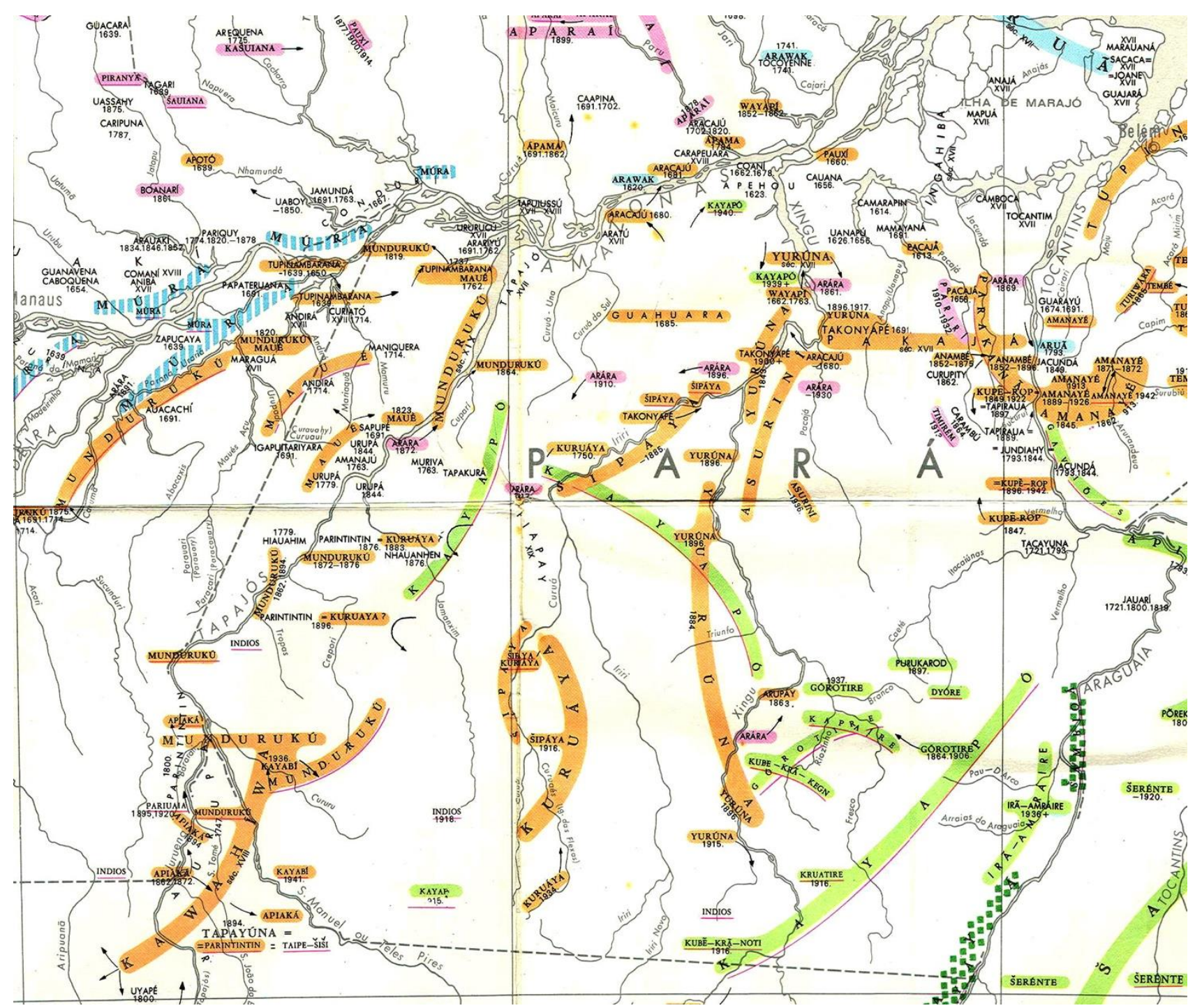

Figura 1"Mapa Etno-histórico do Brasil e regiões adjacentes" adaptado de Nimuendaju (1944) - Fonte: FIBGE 
O relato de Maria Yawaidu sublinha diversos pontos que são recorrentes nas histórias contadas sobre os Xipaya e Kuruaya da região. Nele podemos observar a menção frequente aos episódios de conflitos com os Kayapó:

"Onde eu nasci, no Baú, mamãe contava: com medo de Kayapó eles correram pro Baú. Chegaram no (igarapé) Pitchatcha, daí saíram para o Baú, daí do Baú quando eu era pequenininha ele (meu pai) me trouxe para onde eu moro agora... Lá que eu me criei, no Cojubim. O meu pai que botou o nome Cojubim, ele que botou, quer dizer jacu!"

Esse trecho contém diversos pontos que expõem os momentos fundamentais na constituição das relações entre os Xipaya e os Kuruaya e não indígenas, principalmente seringueiros migrantes da região do nordeste brasileiro. Essas versões estão sempre localizadas nas regiões dos rios Iriri e Curuá e explicam a intensificação das relações entre os Xipaya, os Kuruaya e os seringueiros ao comum conflito contra os Kayapó, “índios brabos”, que forçaram esses dois grupos a se juntarem na colocação do Baú. O Baú é tratado ora como aldeia, ou aparece ligado mais diretamente aos seringais da região, ressaltando a relação com não indígenas, contudo é sempre retratado como o primeiro local onde coabitaram sistemática e intensivamente os Xipaya e os Kuruaya. Essa atribuição, no entanto, pode ser flexibilizada mesmo com informações do relato de Maria Yawaidu que contou como antes de morarem no Baú, seus pais, Bitatá Xipaya e Kiripoco Kuruaya, vieram de uma aldeia, uma grande maloca (Turupá'tu'pá) próxima ao rio Iriri. Por sua vez, relata que nessa aldeia considerada Xipaya, contudo já havia o casamento entre Xipaya, seu pai, e Kuruaya, sua mãe. O mais provável é que não seja exatamente claro para aqueles que já nasceram nas condições de relação estabelecida entre os Xipaya, os Kuruaya e não indígenas, em qual momento essas relações se firmaram de modo significativo ${ }^{22}$, contudo é possível determinar a importância da coabitação no Baú com o ponto fundamental que irá ligar profundamente esses dois grupos e determinar suas relações com os seringueiros da região. As informações trazidas por Nimuendaju no Handbook (1948) sobre os Kuruaya falam do grupo como habitantes do entorno do rio Curuá:

"Father Roque Hundertpfund (about 1750) went up the Iriri River on a 9-day preaching tour to the Curibary (Curuaya) and Jacipoya (Shipaya). After a 9day journey upstream, the priest was still a long way from the mouth of the Curuá River, as it takes 18 days of rowing to get to the Curuá from the Xingu.

\footnotetext{
${ }^{22}$ No próximo capítulo serão abordadas noções sobre a mistura Xipaya e Kuruaya, que também apresentam concepções sobre precedência nas perspectivas locais.
} 
This proves again that the Curuaya formerly lived farther to the north. They were mentioned several times during the 19th century, but only through information given by the Yuruna and the Tacunyape. According to $\mathrm{H}$. Coudreau, who had no direct contact with them, the tribe in 1896 inhabited the forest on the left bank (?) of the Curuá River. The traditions of the tribe, however, only mention excursions to the west of the Curuá, where they had bloody encounters with the Karuziad (Mundurucu) (...) Beyond a doubt they themselves consider as their own territory the tributaries of the right bank of the Curuá River from lat. $6^{\circ} 30^{\prime} \mathrm{S}$. to $8^{\circ} 50^{\prime} \mathrm{S}$. (the bayous Curuazinho, Bahu, and Flechas), where they were found in the 20th century". (NIMUENDAJU, p. 221, 1948).

Nimuendaju indica o ocupação tradicional dos Kuruaya na área próxima aos Xipaya, remontando à ligação antiga entre os grupos, ao remeter às relações de conflito e de alianças entre os grupos, também com os Juruna, e com outros povos: "The Shipaya had been alternately at peace and at war with the Yuruna, Arupai, Curuaya, and Arara but finally effected an alliance with the Yuruna and Curuaya, and, despite occasional flare-ups, intermarried and lived together with them". (NIMUENDAJU, p. 235, 1948). O casamento como aliança entre os grupos é lembrado pelos interlocutores, contudo os relatos não traçam a relação com os Juruna, conforme o autor apresenta. Sobre as relações entre Xipaya e Kuruaya podemos observar exemplarmente no relato de Maria Augusta Borges Xipaya, conhecida como Xipainha, que se reconhece como Kuruaya. Ela conta que sua mãe, Kirinapãe, era Kuruaya e teve um breve encontro com Kaindã Xipaya durante a permanência de ambos no seringal Bom Futuro, próximo ao rio Iriri. Xipainha conta que sua mãe nasceu "para o lado do Mato Grosso", próximo aos igarapés Pitchatcha - também nomeado atualmente como rio Curuaés (MMA, 2009) - e Sabuji - ambos afluentes do rio Curuá -, em local indicado por Xipainha e Ana Kurica, sua irmã mais velha, como sendo uma aldeia apenas dos Kuruaya. Segundo o que contava sua mãe, Xipainha relata que dessa aldeia Kuruaya foram caminhando até o rio Iriri, próximo a Cachoeira do Sangue. Esse deslocamento é explicado da seguinte maneira por Xipainha e Ana Kurica:

“Os Kayapó matavam muitos Kuruaya, era um briga né. Os Kuruaya saíram de lá, mas através de que? Por que os Kayapó não mexiam com eles de jeito nenhum: foi através de um pajé. O pajé, a rede dele era aqui assim armada né, em cima da rede dele tinha um arco e duas flechas. Era a chave para prender os Kayapó. Quando ele estava pra morrer ele fez reunião com os índios 'olha eu to pra morrer... Tem esse arco e essa flecha, se vocês mexerem neles aqui, vocês vão morrer tudo! Vai perder bem-te-vi cantando, bico-de-brasa 
cantando... Vocês vão se acabar tudo, vão se misturar com os brancos, vão acabar tudo!'. Daí pronto, tudo bem. Passou, passou... E ele morreu. Daí a mulher dele, com a ignorância, pegou o arco e as flechas cortou e botou junto com ele, enterrou junto com ele. No dia que eles faziam isso, enterrava o índio dentro de casa, daí mudam daquele lugar, foram lá caçar outra aldeia. Passaram a noite todinha fazendo o velório, o velório deles né. Choravam: chora, chora, chora... fuma, fuma... até o dia amanhecer. Depois o dia amanheceu eles disseram 'vai buscar milho que nós não trouxemos', daí foi que os cabocos voltaram para pegar! Quando chegaram viram de longe que estava cheio de Kayapó lá! Dentro da casa, na roça quebrando milho... aí pronto! Matando Kuruaya, matando Kuruaya... Kuruaya brigando com eles... (Os Kuruaya) vieram parar lá no igarapé do Baú. Lá foi indo... Eles se misturaram com Xipaya, com branco... de lá foi que desceram para o Bom Futuro onde tinha um bocado de índio morando".

Em "Fragmentos de Religião e Tradição dos Índios Šipáia" (1981), Nimuendaju descreve algumas versões contadas pelos Xipaya e pelos Kuruaya sobre a relação entre os grupos:

"Os Šipáia, por causa dos ataques dos Tukamamai (Kaiapó), tinham abandonado o Iriri e ido para o Gorgulho do Barbado, Curuá. Ali viviam, a princípio, em sobressalto constante, temendo que os velhos inimigos os perseguissem até lá. Um dos Šipáia, que era o mais desconfiado, levantava-se frequentemente de noite e fazia a ronda. Numa dessas vezes, percebeu na escuridão uma forma humana se aproximar da aldeia, saindo a rastejar do mato. Imediatamente atirou uma flecha na direção do vulto que, com um gemido abafado, tombou. Quando acenderam uma luz e examinaram o morto - atingido pela flecha acima da clavícula -, descobriram que não era um Kaiapó mas um Kuruáia. Algum tempo depois, quando os Šipáia já tinham roças plantadas, veio um bando Kuruaya e saqueou a plantação. Os Šipáia, quando notaram a presença de estranhos, resolveram tratá-los com bons modos. Esperaram os ladrões, falaram-lhes e fizeram amizade com eles. Eram Kuruáia, de um bando que havia perambulado muito a oeste do Curuá, aonde foram cair entre os Mundurukú, que lhes roubaram todas as mulheres. Os Šipáia deixaram os homens se casarem na tribo, e deles descendem os mestiços Kuruáia que ainda hoje moram entre os Šipáia, no Largo dos Mutuns, perto de Santa Júlia. Mais tarde, entretanto, durante um banquete, reacendeu-se a animosidade entre as duas tribos. No combate que se seguiu os Šipáia usaram pela última vez sua borduna de guerra, as makutu, e, nessa ocasião, talvez também tenham praticado pela última vez o costume da antropofagia. Os Kuruáia, por seu lado, mataram, não faz muitos anos, um bom número de Šipáia, que se tinham estabelecido na sua vizinhança, no 
Igarapé das Flechas. A briga começou porque os Šipáia não quiseram ceder aos primeiros uma viúva do grupo, que era Kuruáia. Ambas as parte me asseguraram que as cabeças dos Šipáia mortos foram transformadas em troféus pelos Kuruáia. Dizem que Karurém, o chefe Kuruáia, as têm guardadas, e, não faz muito tempo, os Kuruaya ainda costumavam dançar com estas cabeças, conforme eles mesmo contaram". (NIMUENDAJU, p. 44, 1981)

Além evidenciar a oscilação da relação entre os Xipaya e Kuruaya - como a aliança entre os grupos podia acabar em conflitos com mortes dos dois lados - o trecho reitera como essa relação, ao que parece, mesmo antes da chegada dos seringueiros, já era relacionada à presença Kayapó, que haviam acuado os Xipaya no rio Iriri e os fizeram adentrar o território do rio Curuá, onde os Kuruaya já habitavam, dizendo vir do norte, onde entravam em confronto também com os Munduruku, como o relato alude. Embora essa seja uma memória antiga, já não relembrada pelos interlocutores que não falam mais da relação belicosa entre os Xipaya e Kuruaya, é interessante como o trecho pode trazer elementos fundamentais para pensar essas alianças (casamento, coabitação e comensalidade) que serão redefinidos e recriados em novos contextos impostos, conforme a dissertação pretende examinar adiante. No momento, é imprescindível reter que relação Xipaya e Kuruaya vai sendo cada vez mais amalgamada, embora Nimuendaju pudesse assistir o momento fundamental dessa coalizão, destacando suas dificuldades:

"A única tribo com quem os Šipáia ainda hoje têm contato, e com quem ocasionalmente convivem, são os Kiriwai (Kuruáia). Kirí é um periquito, e awai designa a comunidade dos membros masculinos da tribo. As relações entre as duas tribos hoje são bastante sofríveis. Em geral, o autêntico Kuruáia não gosta muito do Šipáia, que já foi modificado por todas as maravilhas da civilização; e este por sua vez, manifesta certo desprezo diante do Kuruáia, olhando-o de cima, e provavelmente gostaria de poder rebaixá-lo da categoria tana (gente) para a de adji (selvagem). Até hoje ocorrem desentendimentos entre as duas tribos". (NIMUENDAJU, p. 44, 1981).

A despeito das relações Xipaya e Kuruaya hoje serem tomadas de formas específicas, é notável como o evento de conflito com os Kayapó ganha atenção principal em todas as explicações ouvidas sobre os processos de deslocamentos e mudanças que foram culminar na coabitação entre dos dois grupos e os seringueiros. A descrição supracitada de Xipainha, do evento premonitório que foi a ruína dos Kuruaya, significados repassados pela mãe Kirinapãe, 
retoma o conflito histórico contra os Kayapó dando mostra da intensidade dessa relação na visão Kuruaya. Nimuendaju descreve especificamente como os Kuruaya vão ter sua trajetória determinada pelo confronto:

"Up to this time the Cayapó had respected the Curuaya territory, but from 1918 on they began to extend their incursions to the Curuá River, and in 1934 they attacked and scattered the Curuaya. The largest group of the Curuaya took the road from the mouth of the Riozinho do Iriri to the Tapajoz; other groups scattered along the middle Iriri. The remainder, except for a few who stayed on the Iriri, live together with the last of the Shipaya near "Gorgulho do Barbado" on the lower Curuá. In all, there are perhaps less than 30 of them". (NIMUENDAJU, p. 222, 1948).

Relacionando a desventura Kuruaya essencialmente aos Kayapó, a relação com os não indígenas recém-chegados sob a perspectiva dos interlocutores, embora não se possa falar em equilíbrio, é tomada como uma espécie de coligação com os seringueiros que avançavam sobre as regiões de seringal entrando em conflitos extremamente violentos contra os Kayapó, fazendo dessas histórias verdadeiros relatos de guerra como foi possível ouvir na voz de muitos seringueiros. O marco dessa relação é mais uma vez retomado nas lembranças de Xipainha:

"Era tipo uma aldeia, tinha muito índio lá... Kuruaya e Xipaya moravam lá. Lá que se misturaram os Kuruaya com os Xipaya. Se misturaram dentro do Baú. Aí quando foram morar lá no Bom Futuro, esse Pedro Borges já tinha uma índia Xipaya. Depois essa Xipaya morreu e mamãe já estava gestante de mim. A mamãe já estava lá com eles, aí ficou mulher dele (Pedro Borges), pronto".

O casamento da mulher indígena com o homem não indígena está presente não apenas nos relatos como pode ser percebido claramente na constituição dos Xipaya, Kuruaya e Juruna, sejam moradores da cidade, ribeirinhos ou atuais residentes das terras indígenas Xipaya e Kuruaya ${ }^{23}$. É possível estranharmos a ausência, nesses relatos, de menções ao roubo de mulheres, histórias que são, no limite, previstas nessas situações violentas de contato. Contudo, é preciso pensar que a relação desses grupos com seringueiros tomou uma forma bastante particular por esse período, já consolidada nas falas dos interlocutores. A própria

${ }^{23}$ Sobre esses casamentos, a análise seguirá no próximo capítulo "Entre parentes". 
expansão da exploração da seringa nessa região foi então proporcionada por essa relação entre os Xipaya e Kuruaya com os seringueiros e seringalistas, uma relação determinada em grande medida por casamentos que permitiam a aceitação da aliança com os não indígenas por parte desses grupos. Sobre seu padrasto, o cearense Pedro Borges, Xipainha comenta:

"Primeiro ele cortava caucho. Quando esses índios chegaram que se misturaram tudo, ele ficou como um tuxaua dos índios. Cuidava dos índios, ele era seringalista. Botou os índios para cortar seringa, quebrar castanha”.

O trecho é bastante contundente sobre a intensidade das influências que seringueiros migrantes exerciam sobre os Kuruaya durante esse período, tanto que Xipainha fala de como um seringueiro que virou tuxaua, ou seja, como ascendeu na estrutura social do período por meio da relação com os indígenas, elevado ao status de chefe, considerado também como seringalista pela interlocutora. A mesma o descreve como padrasto e pai de criação não expressando os episódios de violência que podem ter sido constitutivos dessa chefia, contudo deixando claro que havia dois fatores fundamentais para que tal situação fosse possível: guerra contra os Kayapó e aliança com os seringueiros. Essa narrativa é também apresentada por Nimuendaju, oferecendo uma rica contribuição para pensar as novas relações que se estabeleciam entre os indígenas e seringueiros nesse período. No item "Organização Política e Social" do Handbook, Nimuendaju descreve:

"In 1913, the Curuaya still had a village chief, although an intelligent interpreter who had a monopoly on their communication with Neo-Brazilians enjoyed much greater prestige. Emilia Snethlage believes that chieftainship originally passed from father to son. By 1913, the Curuaya were becoming rubber collectors; by 1919, they were mere serfs of a Neo-Brazilian boss (NIMUENDAJU, p. 233, 1948)".

Cumpre notar como os seringueiros, nomeados "neo-brasileiros" pelo autor, são fundamentais para pensar as subsequentes experiências Kuruaya e também Xipaya em Altamira, mais à frente desenvolvidas pela dissertação. Ao mesmo tempo lamenta-se não haver condições de aprofundar a potência da categoria do autor, como conceito para pensar o contato no contexto amazônico durante o período do século XIX e início do século XX. Ao mesmo tempo, acolhemos implicitamente a sugestão, de forma a pensar as questões sobre mistura e herança, desenvolvidas em outro momento pela dissertação. Seguindo o 
empreendimento histórico, anteriormente delimitado, recupera-se a contribuição do relato de viagem de Emilia Snethlage, frequentemente citado por Nimuendaju, que aproveitou muito de seu material principalmente sobre os Kuruaya.

O relatório elaborado para o Museu Emílio Goeldi da naturalista e ornitóloga ${ }^{24}$ Emilia Snethlage (1910) sobre sua travessia entre os rios Xingu e Tapajós, realizada no ano de 1908, é um documento valioso que ilustra alguns aspectos do modo como os Xipaya e os Kuruaya estavam distribuídos nessa região dos rios Iriri e Curuá durante essa época. Formada zoóloga na Alemanha, Emilia Snethlage (1868-1929) chegou a Belém do Pará em 1905, desenvolvendo carreira produtiva e reconhecida como cientista no Brasil. Uma das realizações mais importantes creditadas a autora foi a organização do "Catálogo das aves amazônicas" (Snethlage, 1914). A travessia entre os rios Xingu e Tapajós percorreu um território até então desconhecido pela cartografia e teve repercussão internacional. Em 1914 foi nomeada diretora interina do Museu Paraense Emílio Goeldi e, a partir de 1922, trabalhou como naturalista viajante para o Museu Nacional do Rio de Janeiro. Em 1926 tornou-se membro da Academia Brasileira de Ciências. O relatório Xingu-Tapajós foi o responsável pela autora também interessar-se pela etnografia dos povos que a ajudaram a fazer a travessia, principalmente os Xipaya e Kuruaya, apresentando não apenas indicadores das estreitas relações entre os dois grupos indígenas, como também descrevendo as relações mantidas com seringueiros e seringalistas que já ocupavam essa área. (JUNGHANS, 2008).

O relatório centra-se no interesse em verificar a existência de acesso entre os rios Xingu e Tapajós conforme havia sido sugerido por Coudreau (1977) quando de sua expedição ao rio Xingu no ano de 1896. Os viajantes anteriores (Príncipe Adalberto, von den Steinen e Coudreau) são retomados pela autora durante sua descrição das paisagens e dos percalços dessa região, sendo lembrados especificamente sobre suas contribuições com relação a informações sobre os grupos Xipaya e Kuruaya. Nesse sentido é interessante notar que todos esses viajantes remetem-se a vinculação entre esses grupos, ora ressaltando um deles, ora outro, contudo estes sempre aparecem como mantendo relações de diversas ordens. Ainda, é

\footnotetext{
${ }^{24}$ Além de suas publicações na área de formação a cientista produziu documentos de interesse etnográfico como Vocabulário comparativo dos Indios Chipayas e Curuahé (1912), e a maioria sem tradução para o português: Nature and Man in Eastern Pará, Brazil (1917); Zur Ethnographie der Chipaya und Curuahé (1910) Die Indianerstaemme am mittleren Xingu (1920-21), esses dois últimos publicados no Zeitschrift für Ethnologie.
} 
necessário lembrar que os Juruna também são relacionados à região, recebendo maior destaque nas descrições do Príncipe Adalberto e de Coudreau. A autora destaca da descrição do Príncipe Adalberto o seguinte trecho:

"O príncipe Adalberto falando dos Jurunas e Tacanhapéz continúa: «vem depois os Axipai, que são pouco numerosos; elles são mansos, pouco hábeis e cobardes na guerra e por causa d'isto foram sempre repellidos. Ao contrario os Peapai são numerosos e são elles os inimigos principaes dos Juruna e Tacanhapéz. O mesmo pode-se dizer dos Curíerai, próximos visinhos das três primeiras tribus ás quaes elles movem uma guerra continua >. Esta noticia parece em parte baseada em informações pouco exactas ou mal comprehendidas. Ao menos pode-se dizer quasi o contrario dos Chipaya (Axipai) e Curuahé (Curierai) actuaes. São os Chipaya a raça mais valente e mais numerosa das duas". (SNETHLAGE, p. 58, 1910).

É curioso notar que, no relato de Snethlage não existem menções contundentes ao avanço dos conflitos contra os Kayapó levando-nos a crer que essa situação nas regiões do Iriri e Curuá, embora não possa ser determinado seu início exato, intensifica-se, ou mesmo aparece apenas durante o período próximo ao segundo ciclo da borracha. Ainda, o relatório da pesquisadora não traz muitas descrições sobre a povoação de Altamira, mencionando-a apenas como entreposto para aquisição de bens para a viagem, e fazendo mais referência a outras colônias da região que hoje se encontram nos município de Vitória do Xingu e Altamira, como Victoria, Ponte Nova e Boa Vista. O Forte Ambé ${ }^{25}$ é caracterizado como a principal localidade do início do médio rio Xingu, após a passagem da Volta Grande, localizado possivelmente onde hoje se encontra o $51^{\circ}$ Batalhão de Infantaria na Selva de Altamira:

"No alto da ultima collina antes de chegar a Forte Ambé abre-se uma vista das mais bellas que conheço na Amazónia. O viajante vê em baixo o Xingu, que forma uma bahia larga e magestosa em cuja margem se mostram os edifícios vistosos do Forte e um pouco mais adeante a florescente povoação de Alta Mira (...)Além d'isto os dois últimos logares mencionados têm uma grande

${ }^{25}$ Indico a sugestão de Marta Amoroso, durante a banca de qualificação (2015), sobre a presença dos assentamentos militares e aldeamentos de Catequese e Civilização do Império (1845-1898), que foram parcialmente concomitantes ao primeiro ciclo de exploração econômica da borracha na Amazônia (18791912), projetos de ocupação com afinidades evidentes com relação a proposta de "amansar" e civilizar os indígenas. Construído por volta do ano de 1880, o Forte Ambé veio pouco depois de outro aldeamento mal sucedido tentado pelos capuchinhos italianos, Frei Ludovico Mazarino e Frei Carmelino Mazarino, por volta do ano de 1868 (Patrício, 2000). Embora a dissertação não tenha desenvolvido o tema, que exigiria maior aprofundamento histórico sobre a questão, ressalta sua importância para pensar as consequências do contato para os grupos interlocutores da pesquisa e da região. 
importância commercial, como depósitos de todas as mercadorias exportadas e importadas no médio e alto Xingu" (SNETHLAGE, p. 52, 1910).

Outra importante ajuda para viagem vinda da nascente povoação, e destacada pela autora, foi a contribuição do Coronel Ernesto Accioly com seu conhecimento sobre a região. Além de seu conhecimento, como comerciante e seringalista, é possível notar as nuances do processo de ocupação que se estabilizava naquele momento na região de Altamira, com a exploração econômica da borracha e o lugar em que apareciam os grupos Xipaya e Kuruaya nesse processo:

"De importância ainda maior para a sorte da minha viagem foi o facto que, usando de sua influencia com os Índios Curuahés e Chipayas elle me procurou os guias necessários para atravessar a região inexplorada entre o Curuá e o alto Jamauchim". (SENTHLAGE, p. 53, 1910).

Como indicado anteriormente, os ciclos de exploração econômica da borracha representaram a consolidação de um projeto sistemático de ocupação nacional nas regiões amazônicas produzindo intensas migrações para região, principalmente de migrantes vindos da região nordeste brasileira. Embora não existam referências diretas no texto consultado sobre os confrontos entre os grupos indígenas estudados e o avanço seringueiro na região, é possível deduzir que o contato intenso com a sociedade não indígena tenha representado aos Xipaya e aos Kuruaya desde o início uma posição particular no contexto médio xinguano. Trata-se de uma condição ambivalente para esses grupos, que passaram a se incorporar no projeto de ocupação nacional na região e dessa forma encontraram sua sobrevivência aos impactos da civilização. As descrições de Snethlage contribuem para observarmos a dimensão desse processo nas áreas tradicionais dos grupos Xipaya e Kuruaya:

“O Iriri inferior e médio hoje já estão bem povoados. Coudreau em 1896 ouviu falar de mais ou menos 70 habitantes civilizados n'este rio. Hoje estimase em mais de mil o numero das pessoas occupadas nos seringaes e nas casas de commercio do Iriri, e esta comparação mostra mais que nenhum outro facto o progresso que o desenvolvimento do rio fez em menos de quinze annos. Abundam as barracas de seringueiros nas margens e nas ilhas e a borracha que se produz aqui tem a reputação de ser a melhor do Estado do Pará. Já mencionei as três importantes casas commerciaes de Sta. Júlia, S. Francisco e Bocca do Curuá" (SNETHLAGE, p. 57, 1910). 
Como podemos observar, a atividade seringueira chegava até o rio Curuá, sendo que, embora não houvesse ainda menções as situações de conflitos deflagradas com o avanço dos grupos Kayapó, já ocorria uma intensa relação entre os grupos Xipaya e Kuruaya entre si e com o seringueiros da região. Essa evidência não distorce as informações apresentadas nos relatos das trajetórias de vida, embora esses enfatizem os conflitos com Kayapó. É preciso ter em mente que esse marco dos conflitos com os Kayapó, como dito, lembrado inclusive como uma guerra que se estabeleceu no alto, consolida o grau e a natureza das relações entre os Xipaya e os Kuruaya, e seringueiros. Em muitos relatos, também, sugere-se que atividade de extração da borracha, juntamente com a presença maciça das ocupações nas regiões do rio Iriri passaram a sustentar a permanência dos Xipaya e Kuruaya nessa região. Quando a atividade seringueira diminuiu após o segundo ciclo da borracha, a permanência nessas regiões tornava-se inviável, uma vez que os Xipaya e Kuruaya já estavam profundamente vinculados a essa atividade econômica também. Nesse sentido, o conflito com os Kayapó volta a ser entendido como um marco dessa transformação do mundo dos Xipaya e dos Kuruaya, conquanto a história desses grupos já indicava a antiguidade das relação estabelecidas entre si, embora as informações sejam poucas sobre essas relações e, posteriormente, com os forasteiros não indígenas.

Retomando as informações apresentadas pela pesquisadora Emilia Snethlage (1910), os Xipaya com quem se encontra nas proximidades do rio Iriri são caracterizados da seguinte maneira:

"Segundo as informações que me deu o coronel Ernesto Accioly, os Chipaya vivem hoje retirados da parte civilizada do Iriri-Curuá, embora alguns sirvam como tripulantes no serviço das canoas. Elles são estimados antes de tudo como pilotos perfeitos. As suas principaes malocas acham-se agora no alto Curuá e no alto Iriri. A primeira maloca do Curuá, que se encontra depois de 8 dias de viagem (no verão, em igarité) é a de Manoelsinho, índio intelligente e enérgico, que passou alguns annos entre os civilizados na região de Forte Ambé onde elle adoptou o costume de vestir-se e de usar cabellos cortados. Elle é, ao meu saber, o único indio d'esta região que compreende e falla bem o portuguez, grande amigo dos brancos e especialmente do coronel Ernesto e mediador dos negócios entre os seus patrícios e esse ultimo. No tempo em que eu estava no Curuá, elle ainda era pagão, mas tinha a intenção de baptisar-se na primeira occasião. Os outros chipayas das malocas guardam ainda quasi todos os costumes e o traje primitivos; elles são valentes, amigos dos civilizados em quanto estes últimos não os offendem, mas não podem ser chamados «policiés». A sua lingua é quasi a mesma como a dos Jurunas, como já disse Coudreau". (SNETHLAGE, p. 58-60, 1910). 
Muitos pontos apresentados pela pesquisadora são interessantes para se compreender as especificidades da história dos Xipaya no rio Xingu. Destaca-se, de imediato, a figura de Manoelzinho, índio que aprendeu o português durante uma permanência no Forte Ambé, onde hoje se localiza a cidade de Altamira. Devido a suas relações, segundo as descrições de Snethlage, com coronel Ernesto Accioly, aparenta-se que sua permanência na povoação se deu pelo intermédio do coronel, contudo é possível que Manoelzinho tivesse algum contato com indígenas moradores da Missão. $\mathrm{O}$ fato de apenas um indígena saber o português e ser mencionado como alguém que permaneceu entre os "civilizados" do Forte Ambé também corrobora para a percepção de que os processos de migração massiva para residência na região hoje urbanizada de Altamira tenham ocorrido após a decadência de exploração da borracha no médio rio Xingu.

Outro aspecto menos evidente, que apresenta as particularidades da forma como ocorreu a participação dos Xipaya nos processo de ocupação e formação da região de Altamira, é a incorporação da habilidade dos homens Xipaya na navegação pelos rios, igarapés tortuosos e pedrais traiçoeiros existentes nessa região. Essa qualidade dos pilotos Xipaya é ressaltada em muitos relatos colhidos em campo. Quando do fim da importância da atividade de extração seringueira, muitos deles, já morando em Altamira, passaram exercer exclusivamente a profissão e serem requisitados para navegação em todo rio Xingu e afluentes.

As observações sobre os Kuruaya feitas por Emilia Snethlage parecem carregar a distorção da influência da visão Xipaya sobre o grupo, apresentada principalmente por Manoelzinho, com quem a autora colheu informações sobre esses grupos. Não obstante o viés da pesquisadora, suas opiniões correspondem também a possível situação de relativa subordinação desse grupo no contexto em que foram descritos:

"Os Curuahés parecem occupar uma posição singular. Mansos e medrosos (ao menos os que encontrámos) vivem n'uma espécie de patriarchado sob a regência do Chipaya Manoelsinho. Habitam uma maloca grande n'um igarapé affluente do Curuá, poucos dias acima da d'este Índio. Também em baixo da maloca de Manoelsinho existe á esquerda um igarapé chamado dos Curuahés, porém não mais habitado por elles. Em quanto os trajes, armas, ornamentos d'esta tribu não se distinguem dos Chipayas, a sua lingua é completamente differente, mostrando como escreve o Dr. Koch mais affinidades com a lingua mundurucu. Isto parece confirmar a tradição que existe no Jamauchim. Ha n'este rio malocas desertas que segundo dizem estavam habitadas nos tempos antigos pelos Curuahés. São também principalmente estes Índios que até hoje fazem ás vezes excursões ao alto Jamauchim. Do outro lado pode-se vêr das 
noticias do príncipe Adalberto e de Coudreau que já muitos annos antes, os Curuahés eram uma tribu bem conhecida no Xingu. Parece-me provável que os Curuahés que encontrei sejam com effeito restos ou descendentes dos Índios do Jamauchim...” (SNETHLAGE, p. 60, 1910).

A condição precária em que se encontravam esses grupos, observada na descrição de Snethlage, aparentando serem subjugados não apenas pela invasão seringueira, mas também pelos próprios Xipaya, é outro fator que aparece nos relatos ouvidos, sendo possível inclusive indicar uma recorrência do casamento entre homens Xipaya e mulheres Kuruaya nessa época, um fenômeno que pode indicar a relação desigual entre esses grupos. Contudo, essa condição apresentada desses Kuruaya, observada pela pesquisadora, pode ser interpretada com outras nuances se levamos em conta as informações contidas nos relatos colhidos em campo. Os antigos Kuruaya são lembrados como tendo relações menos intensas com os seringueiros durante o período de realização dessa atividade, sendo apenas, novamente, o conflito com os Kayapó o principal motivador de sua aproximação com os Xipaya e principalmente a permanência nos seringais. Embora os Kuruaya apareçam no relatório na condição de submissão, como são retratados por Snethlage, é possível deduzir que essas características observadas pela pesquisadora alemã para esse grupo não sejam apenas particulares a esse caso específico, mas mantenham relações com o modo de ocupação dos Kuruaya, considerados povos do centro da mata, enquanto os Xipaya são considerados povos de beira de rio ${ }^{26}$. Esse padrão de ocupação promoveu diferenças no relacionamento de ambos os grupos com os não indígenas intrusos, conforme nos lembra Xipainha sobre o primeiros contatos dos Kuruaya com os seringueiros, em suas palavras, “os Xipaya já estavam fracos, eram de beira de rio, já viam muitos brancos...".

Outras indicações da pesquisadora aprumam-se com as descrições dos relatos de Xipainha sobre a localização das aldeias onde sua mãe viveu com os Kuruaya. A menção ao rio Jamanchim, muito próximo já da bacia do rio Tapajós, confirma as relações dos grupos Kuruaya e Mundurucu, que tem a língua d mesma família. Essa ligação entre os dois grupos pode ser observada, segundo a leitura de Xipainha sobre os saberes repassados por sua mãe, no seguinte trecho revelado pela mesma:

${ }^{26}$ Nimuendaju (1948) distribui da seguinte forma os grupos indígenas do baixo e médio rio Xingu: “(1) Canoeing tribes restricted to the Xingu, Iriri, and Curuá Rivers: Yuruna, Shipaya, Arupai. (2) Tribes of the central virgin forest: Curuaya, Arara, Asurini, and, formerly, Tacunyape. (3) Savanna tribes that only temporarily invade the forest zone: Northern Cayapo" (NIMUENDAJU, p. 213, 1948) 
"A mamãe contava assim: dizia que os Kuruaya estavam vindo andando pela mata. Daí uns saíram para caçar, foram para o campo. Daí andaram, andaram, andaram... Até que uma mulher que estava pra dar neném, pariu no meio da viagem. Aí o que aconteceu: o menino nasceu e pegaram, foram embora e a placenta ficou lá. Aí os outros que vinham atrás pegaram a placenta e comeram. Quando foi que eles se encontraram, aí eles: 'ah rapaz que foi a caça que vocês mataram e deixaram pra gente?' ai os outros acharam graça e começaram a dar risada deles 'Mas que caça? Essa é a placenta da mulher que ganhou rapaz!' Ai eles ficaram com vergonha e se debandaram. Mamãe dizia que esses eram os Munduruku”.

A localização tradicional dos Kuruaya (próximos ao rio Curuá, no igarapé Pitchatcha, seu afluente que se aproxima do rio Jamanchim) consiste em outro fator que compõe a proximidade desse grupo com os Mundurucu. Quando da época da expedição de Emilia Snethlage foram os Kuruaya requisitados para a travessia que era o objetivo maior de seu empreendimento, do rio Xingu ao Tapajós. A possível ligação entre as duas grandes bacias era conhecida dos Kuruaya por tratar-se de seu território tradicional como foi verificado pela pesquisadora. Após viajar pelo rio Curuá a cientista alemã encontra seus novos guias:

"Logo depois da nossa chegada o coronel Ernesto approntou-se para subir o
rio até o igarapé habitado pelos Curuahés, onde queria trocar ubás e caxiris e
arranjar os guias necessários para a minha travessia (...) Quando cheguei lá na
manhã, achei alem dos quatro guias arranjados por Manoelsinho, três
voluntários para acompanhar-me. A nossa companhia de viagem consistia
assim de oito pessoas, quatro homens e quatro mulheres. Eramos, a bem de
minha pessoa, o velho Maitumá com as suas duas mulheres, Comaicarú e
Umarú, João (o único que sabia algumas palavras portuguezas) com a sua
mulher Parimarú, Topa e um outro Curuahé, cujo nome não cheguei a saber
(...) Todos estes Índios eram Curuahés". (SNETHLAGE, p. 69-72-73, 1910).

Tanto o relatório de Emilia Snethlage como os relatos de Xipainha, dentre outros documentos lidos e trajetórias de vida ouvidas durantes a pesquisa, nos informam sobre os sentidos decisivos que contém as migrações para a formação da vida social dos grupos indígenas residentes na cidade, e consequentemente na constituição dos processos de ocupação e desenvolvimento de Altamira. As referências ao contexto passado no rios Iriri e Curuá, para os Xipaya e os Kuruaya que se deslocaram para o estabelecimento na cidade de 
Altamira, constituem-se em eventos fundamentais na conformação das condições particulares da vida social entre os indígenas da cidade. A reflexão sobre essas relações será objeto de investigação na sequência da pesquisa, contudo, ainda mantém-se o foco nas consequências sobre o conhecimento histórico produzidos nesses discursos, recaindo sobre os interesses de uma investigação sobre a história da formação dos bairros e de Altamira sob a influência da presença indígena. O intuito de apreender as possibilidades que os pontos de vista Xipaya e Kuruaya da Altamira atribuem a essas histórias corresponde a tentativa de responder analiticamente às especificidades das experiências dos interlocutores da pesquisa nessa extensa região. A apresentação de trechos de documentos da história dessa área do rio Xingu, juntamente com as memórias e relatos de trajetórias de vida de alguns dos atuais moradores Xipaya e Kuruaya de Altamira, revela um aspecto da densidade empírica com que a pesquisa teve de lidar apenas para desenvolver questões preocupadas com as histórias indígenas da cidade.

\subsection{Conclusões: contribuições do debate entre antropologia e história para uma etnografia dos indígenas da cidade de Altamira.}

Como apresentado anteriormente, a dissertação não pretendeu retomar o extenso campo de debate que compreende a relação entre antropologia e história, limitando-se a considerar as fontes históricas sob o ponto de vista etnográfico, ou seja, problematizando a história da presença Xipaya e Kuruaya em Altamira por meio das referências de memória dos interlocutores. Contudo, cumpre retomar algumas reflexões que se constituíram ao longo desse debate e contribuíram para a forma como essa proposta de história etnográfica se

formou. É difundido nos anais antropológicos a convenção que distingui explicações sincrônicas e diacrônicas, determinante não apenas para consolidar a disciplina ao nível institucional, mas também para firmar métodos, modelos e recortes analíticos para produção do conhecimento antropológico. A despeito da contribuição recíproca entre antropologia e história, pretende-se recuperar, conforme sugere Schwarcz (2005) "alguns momentos em que a antropologia, enquanto disciplina, refletiu sobre a história". Ao passo que, imediatamente traindo essa rigidez, será possível extrair dessa reflexão de que modo essa história produzida pela antropologia afeta as noções do conhecimento histórico canonizado. 
Inicialmente devemos lembrar, conforme sugere Schwarcz (2005) que a antropologia lidou sempre com histórias: desde aquela indiscutivelmente ligada à forma sacralizada no conhecimento ocidental, pautada pela cronologia e pela comprovação documental; passando pela história que flexibiliza as noções de temporalidade, sendo assim entendida como categoria social, para finalmente empreender uma crítica a uma determinada "Filosofia da História" cunhada em noções excludentes de verdade. De forma geral, então, a antropologia agrega a esse debate o conceito de historicidades. Esse particular decisivo para antropologia é forjado no ponto que inicialmente a relegava a ser um conhecimento supostamente ahistórico: a experiência etnográfica, como pressuposto fundamental do saber antropológico, exige que lidemos com a história no plural. Se hoje antropologia já avança a passos largos sobre essa relação frutífera, antes ela era considerada no mínimo inusitada, para não dizer fantasiosa. Pois, para algumas escolas culturalistas e outras funcionalistas da antropologia, a sincronia era o único meio de compreensão possível para as sociedades não letradas. Embora fosse possível identificar nesse projeto a tentativa de lidar seriamente com as sociedades estudas pela antropologia, em contraposição à uma história acusada de fictícia empreendida pelo evolucionismo antropológico do século XIX, algumas antropologias acabaram atuando com um ranço anti-histórico, ao decretar que a antropologia não era capaz de lidar com explicações históricas sobre os povos por ela estudados. Assim, resumidamente, esse debate levou não a atribuição da a-historicidade dos povos estudados pela antropologia, possivelmente classificados como pré-históricos numa concepção evolucionista dos povos, mas sim a uma evidenciação de que as sociedades as quais a antropologia se interessava mantinham uma relação específica com o conhecimento de sua história: sua ausência na antropologia era reflexo das teorias nativas, que não estavam preocupadas com a produção do conhecimento histórico. Peca-se aqui pela síntese de um debate que foi empreendido em graus elevados, contudo embora não se possa simplificar esse posicionamento, é preciso remeter-se à predominância que a perspectiva sincrônica tomou quando essa evidência não podia ser superada analiticamente (SCHWARCZ, 2005).

Sem alongar nos pormenores dessa recuperação do debate entre antropologia e história, é preciso lembrar que Lévi-Strauss lançou as bases para se re-situar a história perante a antropologia, expressa na consagrada afirmação presente em O Pensamento Selvagem (2011) no capítulo dedicado à crítica da dialética histórica de Sartre:

"Uma história verdadeiramente total neutralizar-se-ia a si própria; seu produto seria igual a zero. O que torna a história possível é que um subconjunto de fatos tem, num dado período, aproximadamente a mesma significação para um 
contingente de indivíduos que necessariamente não viveram esses fatos e que podem mesmo considerá-los a vários séculos de distância. Portanto a história nunca é a história, mas a história-para”. (LÉVI-STRAUSS, p. 286, 2011).

Seria injusto reduzir a contribuição de Lévi-Strauss para esse debate apenas à noção de história-para, contudo opta-se por reter isoladamente esse momento de sua obra, que foi capaz de produzir tantos efeitos para as antropologias realizadas posteriormente, como é evidente sua contribuição para a antropologia da história de Sahlins, por exemplo (Schwarcz, 2005).

Lembra-nos Goldman (1999) que a distinção estabelecida por Lévi-Strauss entre sociedades quentes e frias afasta-se sensivelmente da velha oposição entre povos com e sem história. Portanto, o etnógrafo poderia pensar historicamente esses povos, pouco afeitos ao modo ocidental de registro e pensamento histórico, na medida em que pode traduzir perspectivas diferentes sobre o tempo passado:

"As distintas historicidades peculiares a cada sociedade ou cultura constituem a forma particular através da qual elas reagem ao fato inelutável de que estão no tempo ou no devir. Nesse sentido, tanto a "história dos historiadores" quanto a "filosofia da história" fazem parte constitutiva de nossa forma particular de historicidade, ou, ao menos, daquela dominante no Ocidente há muitos séculos. O que significa simplesmente dizer que da nossa forma de reagir à temporalidade faz parte um certo tipo de reflexão sobre ela. Talvez aqui resida um dos sentidos da aproximação entre mito e história, ou da hipótese de que a história funciona, entre nós, como nosso mito. Muito mais que uma mera "relativização" do saber científico, trata-se aqui de revelar que diferentes tipos de historicidade estão articulados com diferentes tipos de reflexão acerca delas, os quais, por sua vez, fazem parte do tipo de historicidade sobre o qual refletem" (GOLDMAN, p. 199, 1999).

A etnologia ameríndia torna-se um campo privilegiado nesse debate, com importantes contribuições trazidas pelas pesquisas que abordam o problema da história nas perspectivas das culturas estudadas. A etnografia, nesses estudos, assume um papel significativo para a revisão dos termos em que as histórias indígenas são abordadas e apresentadas, problematizando esquemas analíticos que influenciaram durante anos a análise antropológica, como os conceitos de aculturação, e o próprio conceito de cultura, do qual é derivado, pensada em termos essencialistas. Nesse sentido, a percepção do contato interétnico é repensada, de modo que leituras simplistas que atribuam ora um papel romântico na história dos povos indígenas, reduzidos a guardiões de uma cultura tradicional ameaçada de extinção, 
ora apenas como povos que sofrem as consequências do processo civilizatório, tornam-se insustentáveis com relação aos contextos etnográficos experienciados. Para a etnologia, as consequências trazidas pela reconsideração do contato traduzem não apenas uma transformação teórico-metodológica da disciplina, pois estão implicadas em novos contextos sociopolíticos, obrigando ao conhecimento antropológico acompanhar as novas questões que os interlocutores apresentam para o pesquisador e para a pesquisa.

É nesse movimento que Of Mixed Blood: Kinship and History in Peruvian Amazônia, de Peter Gow (2006) torna-se uma referência fundamental para etnólogos americanistas ao consolidar importantes desenvolvimentos analíticos para se pensar a história indígena e o problema do contato interétnico. $\mathrm{O}$ autor realiza com exemplar sensibilidade sua leitura sobre a natureza de afirmações dos nativos Piro, como aquela que abre seu livro: "As pessoas desta área da Amazônia peruana frequentemente dizem ser de sangre mezclada, 'de sangue misturado'." (GOW, 2006, p. 197). Perseguindo essas categorias de classificação "racial" dos Piro, que envolvem um complexo sistema de atribuições, o autor identifica significados que revelam que tais noções não se encaixam nos modelos de raça e de cultura com os quais estamos acostumados:

"Para os nativos, "ser civilizado" não é oposto a uma cultura idílica "tradicional" que vem se perdendo, mas sim se opõe à ignorância e ao desamparo dos antigos ancestrais moradores da floresta. Ser "civilizado" é ser autônomo, viver em aldeias de acordo com os valores dos próprios nativos, ao invés de viver dos caprichosos desejos de um patrão". (GOW, p.198, 2006).

Ao lado de autores como Sahlins (2008), Carneiro da Cunha (2009), Fausto (2007), entre outros, Peter Gow pretende confluir contribuições teóricas de antropologias que poderiam ser consideradas inconciliáveis por leituras imediatistas: trata-se de abordar um problema que se apresenta na ordem da diacronia recuperando análises inspiradas na sincronia:

\footnotetext{
"Seguindo o estilo dessas etnografias de povos 'tradicionais', procurei por coerência e integração nas vidas das pessoas nativas, não incoerência e desintegração. Em lugar de atribuir parte da prática das pessoas nativas à cultura tradicional e o resto à falsa consciência ou às percepções distorcidas, procurei pela coerência interna entre diferentes campos de práticas" (GOW, 2006. p. 213-14).
} 
Essa proposta e postura etnográfica são mesmo estruturadas, segundo o autor, para que os Piro possam ser pensados pela antropologia. Significa dizer que é necessário que se leve radicalmente a sério as referências Piro, impedindo que nossos esquemas estratifiquem seus valores segundo uma hierarquia que lhes destituam de suas próprias escalas. "Por que a cultura não é um objeto em vias de extinção", nas palavras de Sahlins (1997), os Piro mantiveram-se ativos e criativos a despeito das situações de destruição as quais tiveram de lidar, que o autor recupera das historicidades Piro - que falam dos tempos de escravidão até os dias melhores aventurados da comunidade nativa.

Se negociação não parece um bom termo para se representar as relações que se estabeleceram entre povos indígenas e as sociedades nacionais, seja tanto na história do Peru como do Brasil, ausentar a agência dessas populações nos processos dos quais participaram e participam é uma recíproca tão falaciosa quanto. Assim, qualquer antropologia que se incomoda com o eufemismo trazido pela ideia de "encontro", como critica Carneiro da Cunha (2012), deve ter o cuidado de considerar as desigualdades e conflitos produzidos nos processos de contato que se apresentam em todas as histórias ameríndias. Tal acuidade com os dados etnográficos permite-nos aproximarmos das "múltiplas e complexas estratégias da resistência cultural na Amazônia nativa" (GOW, 2006, p.219).

Os argumentos apresentados para problematização das contribuições da história para a antropologia mantêm sólido o compromisso antropológico fundamental que é a consideração efetiva da alteridade, no sentido radical que essa responsabilidade proclama, cuja consequência leva-nos a pôr em questão nossas identidades, ou seja, atinge nossos modos não apenas de pensar os outros como a nós mesmos. As contribuições contidas em possíveis histórias dos indígenas citadinos de Altamira incidem diretamente sobre essa questão, uma vez que complexificam as noções de diversidade mobilizadas na análise antropológica. Isso significa que toda consideração analítica, baseada nas informações colhidas entre os moradores de Altamira, bem como nos documentos consultados sobre a história dessa região, perpassa um emaranhado de ações e percepções constitutivas dos processos específicos de ocupação dessa região do rio Xingu; ou seja, não há uma história, nem mesmo duas, mas sim múltiplas histórias, suportadas não apenas pela diversidade ameríndia, como também pelas ondas de migrantes, pelas camadas sociais locais, sujeitos nacionais ou mesmo agências internacionais que operam interesses e perspectivas nessa região ${ }^{27}$. Sendo a pesquisa uma

${ }^{27}$ É preciso destacar que atualmente, com construção de Belo Monte, essa composição torna-se latente e com contornos dramáticos. Essa composição contemporânea será abordada no desenvolvimento da dissertação. 
reflexão em torno das condições dos indígenas citadinos de Altamira, proporcionada pela etnografia, torna-se necessário a tentativa de cumprir com objetivos ora discutidos que atravessam tal empreitada: discutir as historicidades determinadas pelos Xipaya e Kuruaya residentes nos bairros do Muquiço/São Sebastião e Missão/Jardim Independente é levar em conta as relações que essas pessoas, observando processos coletivos, mantiveram e mantém com diferentes grupos que também compõem essas histórias de contato. Nesse sentido o que é e como falar do ponto de vista dos Xipaya e Kuruaya que moram na cidade, num espaço onde a ocorrência de casamentos entre indígenas e não indígenas, trabalho assalariado, educação escolar regular, o português como única língua, entre outros, fazem parte do modo de vida diário dessas pessoas, hábitos, por sua vez, que são facilmente interpretados como "não tradicionais", tipicamente urbanos, ou mesmo não indígenas, fazendo do sentido de contato nessas circunstâncias soar como plena integração ${ }^{28}$ Imersa em seu tempo, permeado de anacronismos ainda perigosos, a antropologia já não lida com os equívocos elementares ligados a ideia de "perda cultural". A despeito de seu avanço intelectual, o conhecimento antropológico não pode furtar sua análise dos problemas ligados ao seu ambiente social de produção, composto seja por desconhecimentos sobre a situação dos indígenas brasileiros atuais, ou por interesses ofensivos às essas populações. Como defende Carneio da Cunha (2009): "Os direitos dos índios à sua terra, diz a Constituição, são históricos, e a
história adquire uma imediata utilidade quando se trata de provar a ocupação.
Mas ela tem também um caráter de resgate de dignidade que não se pode
esquecer" (CARNEIRO DA CUNHA, p. 126, 2009).

Pareceu prudente, em vista do mau uso possível da pesquisa, responder a questão levantada, inicialmente lançando mão de uma séria reflexão em torno do que os relatos sobre trajetórias de vida dessas pessoas revelam a respeito das particularidades desse processo, de forma a encontrar convergências nesses enunciados que dessem conta não apenas de compreender a forma como esses processos se estabeleceram, ao modo, como foi dito de um interesse próximo ao da investigação histórica, mas também, ressaltando aquilo de específico que contém nesses enunciados. E esse último objetivo, que torna esse estudo essencialmente antropológico, a tentativa de compreender quais significados estão envolvidos quando os interlocutores contam suas histórias. O estudo sobre as historicidades dos Xipaya e dos

${ }^{28}$ Se esse parece ser um problema incontornável no caso de indígenas moradores de espações urbanos é, contudo tão insensato quanto desconsiderar sua importância em etnografias de indígenas aldeados. 
Kuruaya de Altamira exige do antropólogo que seus esquemas conceituais de representação da diversidade acompanhem a sutilezas dos modos de distinção desses grupos que estão imersos nessas configurações específicas de contato e de mistura. Assim podemos retomar o desconforto do pesquisador, revelado anteriormente, ao mobilizar as "formas" de memórias e trajetórias de vida para a análise dos regimes de historicidade entre os indígenas de Altamira: a reflexão proposta até aqui não pretendeu defender qualquer categoria de história oral abrangente - como conceito para pensar sociedades "não letradas", por exemplo - mas sim traduzir o valor de memória e trajetória de vida enquanto eixo analítico fundamental para a compreensão de experiências Xipaya e Kuruaya contemporâneas e suas transformações.

Esse primeiro movimento da dissertação é um momento para o embasamento das abordagens que se seguem nessa etnografia dos grupos indígenas citadinos. Se a preocupação com a história do bairro do Muquiço/São Sebastião nasceu das percepções do pesquisador quando de sua primeira estadia na região - além da urgência dada pelo horizonte de alagamento do bairro com a construção da usina de Belo Monte - a expansão desse problema, até certo ponto prevista, é fruto da experiência de campo intensa com os interlocutores da pesquisa. Essa experiência permitiu localizar as histórias discutidas ao longo deste Capítulo 2 no bojo dos processos latentes que se observam atualmente entre indígenas e não indígenas, na cidade, no rio e nas aldeias. Assim, toda análise histórica que se pretendeu nesse momento da etnografia está estruturada no sentido que essas histórias e historicidades revelam sobre valores presentes nas relações entre indígenas e não indígenas de Altamira. Isso corresponde às situações encontradas em campo; por exemplo, as distintas versões das histórias sobre os bairros do Muquiço (São Sebastião) e Missão (Jd. Independente), que apresentam disparidades entre famílias Xipaya e Kuruaya, correlacionam-se indiretamente nas relações entre as mesmas e na composição das associações indígenas citadinas. Esse quadro de particularidades das experiências indígenas em Altamira é objeto do capítulo seguinte. Seu eixo de análise é provocado por evidências de como os pontos de vista indígenas sobre a história de Altamira e região são produzidos em torno de valores próprios, ligados a categorias de parentesco e vizinhança, que por sua vez compreendem espacialidades características no contexto da cidade. Assim, o domínio das histórias indígenas sobre os tradicionais bairros Xipaya e Kuruaya de Altamira é vinculado à autoridade dos idosos, 
reconhecidos como detentores dos saberes sobre os antepassados. Por outro lado, as versões históricas estão submetidas aos esquemas do parentesco, o que significa dizer que embora o conhecimento histórico não seja questionado, na maior parte dos casos seu lugar está intimamente sustentado pelos valores familiares. Mais uma vez, a análise de Peter Gow nos inspira a compreender que história e parentesco não podem ser encaixotados entre sincronia e diacronia:

\begin{abstract}
"Quando meus informantes estruturavam uma narrativa histórica sobre o passado com a frase: 'Mi mamá me contó que ...' (Minha mãe me contou que ...), era eu, e não eles, que reagia à aparente insuficiência da história doméstica contada face à história mundial. Para gente nativa, uma narrativa obtém seu poder de veracidade precisamente de tais relações de parentesco próximo. Essa é outra dimensão para minha análise da história como parentesco para as pessoas nativas do Baixo Urubamba. História é a narrativa da criação do parentesco contemporâneo $e$ a fonte das respostas das pessoas nativas às novas situações" (GOW, p. 214, 2006).
\end{abstract}

A dissertação seguirá, então, na tentativa de localizar os termos em se produzem esses discursos e práticas que estruturam noções de pertencimento e distinção entre os Xipaya e Kuruaya de Altamira. Os valores de parentesco e vizinhança, enquanto princípios que formulam alianças e conflitos, são categorias fundamentais para se pensar as experiências indígenas na cidade e seus espaços relacionados. Nas palavras de um interlocutor que acabava de esperar a saída de outro, após uma discussão em torno de um mesmo episódio histórico: "Ela falou da história da família dela, agora eu vou falar da minha".

Retendo do capítulo 2 o ponto central da migração Xipaya e Kuruaya para Altamira, oriundo das relações de aliança estabelecidas com os seringueiros e de conflito com os Kayapó, podemos avançar em direção às formulações indígenas sobre casamentos e convivências que, por outro lado, nos contam sobre misturas e precedências. Na visão de Maria Yawaidu sobre a situação dos Xipaya e Kuruaya:

“Eu tenho medo é de branco agora! É de batizado, aí eu tenho medo. Primeiro eu tinha medo de Kayapó, agora Kayapó não sai mais porque o chefe deles diz assim para eles: 'aqui é lugar de vocês, daqui vocês não vão sair, só quando eu mandar pra vocês saírem, buscar uma coisa, vocês vão!’ Mas eles são bons pra escutar, não teimam não... Eles não vão nem lá em casa, quando eu estou lá (aldeia Cojubim). Agora Xipaya e Kuruaya? Não tem isso não! Você pode dizer: 'é, eu quero que vocês não saiam não!' Quando você vira as costas, eles 
vão embora! Eu mesmo, gosto de andar... (...). Agora nós cabocos, Xipaya com Kuruaya, é muito coisado! Não para não, é por isso que perdeu (as terras). Aí, hoje em dia: 'ah, Dona Maria vamos embora, nós vamos fazer reunião grande para você pegar de novo essa terra', aí eu dizia: 'agora não pode! Como vai? Só eu falando vai ganhar essa terra aí!' (área da Missão/Jardim Independente II). Assim, primeiro não tinha branco, aí esses caboco velhos que moravam aí, se pensasse... pegava papel, tirava documento. Ah, aí eu não tenho medo de entrar no meio, estou com documento né?" 


\section{ENTRE PARENTES: ETNOGRAFIA DAS FAMÍLIAS INDÍGENAS DE ALTAMIRA-PA}

\subsection{População indígena da cidade de Altamira - diálogos com as pesquisas quantitativas}

A compreensão dos processos históricos e socioculturais constitutivos da condição dos grupos indígenas residentes da cidade de Altamira também compreende a análise do universo populacional nesse meio urbano. Mesmo que o presente estudo não pretenda desenvolver uma análise demográfica da população indígena de Altamira, é importante para etnografia apresentar um breve apanhado de indicadores, que caracterizam aspectos socioeconômicos dessa população, como número populacional, condições de vida, migrações, entre outros. Essa apresentação não perde de vista a fundamentação etnográfica do trabalho, voltado para construção de um recorte capaz de discutir aspectos basilares de determinadas experiências por que passaram e estão passam os grupos indígenas historicamente ligados a formação da cidade de Altamira, por meio das sugestões apresentadas pela experiência de campo junto aos interlocutores.

Observar os dados oficiais sobre as populações indígenas do Brasil é sempre um desafio aos pesquisadores, contudo, como indica Azevedo (2011), "a invisibilidade estatística" dos povos indígenas é um problema que vem sendo enfrentado pelo metiê acadêmico e paulatinamente incorporado pelas instâncias governamentais como se observam nos resultados do Censo IBGE 2010. Nessa esteira torna-se possível trazer aos estudos antropológicos sobre populações indígenas alguns dados sobre demografia que colaboram para o aprofundamento das questões teóricas que a disciplina produz a partir de seus contextos etnográficos. Sem adentrar especificamente nas consequências para metodologia da pesquisa demográfica serão apresentados a seguir alguns avanços dos dados oficiais, contidos principalmente nas estatísticas dos Censos (IBGE, 1991, 2000 e 2010), ao lado de dados censitários de outras naturezas, principalmente atrelados aos estudos ambientais de antes e durante à construção da UHE - Belo Monte ${ }^{29}$. Título de nota também foram os estudos demográficos sobre a população indígena da área urbana de Altamira realizados por Simoni e

\footnotetext{
${ }^{29}$ Nota-se que esses dados estatísticos correspondem ao universo indígena da cidade de Altamira contudo delimitado pelo interesse sobre as diversas interferências que a obra da usina desencadeia nesse ambiente, tal como é conduzido o Estudo de Impacto Ambiental EIA/RIMA.
} 
Dagnino (2012) que fazem uma análise das informações populacionais e históricas desses grupos.

Altamira é um município de grande extensão territorial abrigando 12 Terras Indígenas parcial ou totalmente inseridas em seu território. $\mathrm{O}$ total da população indígena indicado pelo Censo de 2010 para o município de Altamira é de 3711 pessoas, sendo que 823 estão localizados em zona urbana, correspondendo a $0,98 \%$ do total da população urbana do município. Em comparação com os valores do Censo de $2000^{30}$, quando o total da população indígena na zona urbana de Altamira era de 120 pessoas, o que correspondia a 0,20\% do total da população urbana do município, observou-se uma taxa de crescimento de 20,74 da população indígena na cidade. A título de comparação, a taxa de crescimento da população de Altamira foi de 3,05 e a indígena como um todo (tanto urbana como rural) foi de 11,15 (SIMONI \& DAGNONI 2012 apud IBGE, 2010).

\footnotetext{
${ }^{30}$ Os dados do Censo de 1991 não podem ser comparados aqui pois correspondem a extensão territorial quando o município ainda não tinha sido dividido dando origem ao município de Vitório do Xingu.
} 


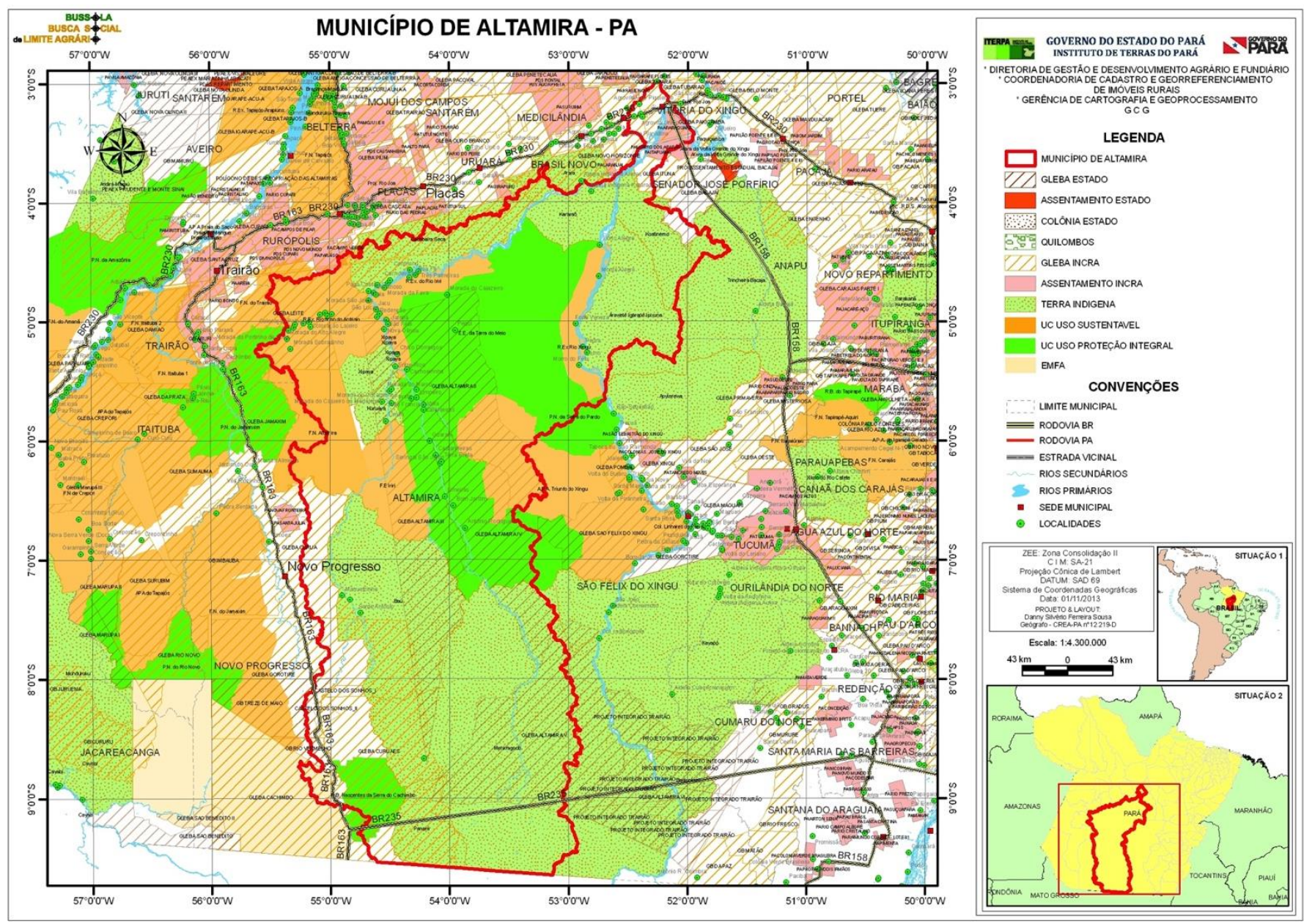

Figura 2 - Mapa do município de Altamira-PA contendo as delimitações de terras indígenas. 
Observando em números absolutos e proporcionais, a população de indígenas residente na cidade de Altamira $^{31}$ fica abaixo de outras cidade amazônicas com grandes populações indígenas, como São Gabriel da Cachoeira no estado do Amazonas. Embora os dados relativos ao total populacional não expressem a importância do fenômeno populacional indígena em Altamira, a taxa de crescimento da população indígena na cidade é um indicativo da significância atual da presença indígena na cidade. Nesse momento é interessante retomar as discussões operadas no capítulo anterior, em que foram apresentados alguns aspectos históricos da presença indígena na região e principalmente na cidade de Altamira. O segundo capítulo argumenta sobre a importância de determinados grupos indígenas não apenas na composição da população urbana do município, como na própria origem da cidade. Os grupos então apresentados constituem-se principalmente nos Xipaya, Kuruaya e Juruna. Mostrou-se como a história da formação da cidade está intimamente ligada à trajetória desses grupos que até hoje se vinculam de maneira particular à cidade de Altamira. Não foi possível identificar a partir dos Censos a proporção das etnias que compõem a população indígena urbana de Altamira, contudo esses dados são observados nos estudos ${ }^{32}$ ligados a construção da usina de Belo Monte, conforme é apresentado a seguir:

Tabela 1 - Proporção das etnias da população indígena urbana de Altamira - PA.

\begin{tabular}{|c|c|c|}
\hline Etnia /Ano & $\mathbf{2 0 0 2}$ & $\mathbf{2 0 0 9}$ \\
\hline Xipaya & 44,20 & 38,24 \\
\hline Kuruaya & 36,23 & 25,58 \\
\hline Juruna & 7,97 & 13,83 \\
\hline Kayapó & 5,80 & 6,17 \\
\hline Arara & 1,45 & 4,11 \\
\hline Karajá & 1,45 & 0,58 \\
\hline Outros & 2,90 & 11,49 \\
\hline Total & 100,00 & 100,00 \\
\hline
\end{tabular}

Fonte: Eletronorte, 2002 / Equipe V, 2009

Nesse quadro é possível identificar a importância dos grupos supracitados para a composição da população indígena da sede urbana de Altamira. Contudo é interessante notar,

\footnotetext{
${ }^{31}$ Além da sede municipal, o município de Altamira também abriga o distrito de Castelo dos Sonhos considerado área urbana.

32 Compreendem os estudos ambientais que avaliaram a viabilidade do empreendimento (Estudo de Impacto Ambiental EIA/RIMA, 2002 e 2009) também trabalho posterior de monitoramento da realocação urbana dos indígenas moradores de Altamira (Norte Energia, 2011).
} 
ao comparar os dois levantamentos realizados, que a contribuição dos grupos Xipaya e Kuruaya passa a diminuir, em comparação ao incremento percebido para os outros grupos. Embora a presença dos Juruna tenha aumentado, e também dos Arara, grupos que podem ser ligados mais estreitamente a formação do município, observa-se um possível fenômeno recente que atrai novas migrações para a cidade, como denota-se no crescimento da proporção de “outros” grupos étnicos na composição da população indígena. Outra reflexão advinda dos dados soma-se à percepção levantada pela etnografia, que situa as particularidades da relação dos grupos indígenas interlocutores da pesquisa com a situação urbana de Altamira, em outras palavras, como a história desses grupos teve um profundo vínculo com as frentes de ocupação dessa região. Nesse sentido, haveria uma aparente contradição que, por sua vez, revelaria os desenvolvimentos do instrumental teórico para se pensar a condição desses grupos indígenas, que num momento foram classificados como "extintos" e atualmente tendem a ser identificados por agentes externos como "ressurgentes", entre outros termos afins. Sob o olhar das políticas oficiais, ou mesmo da capacidade das ciências sociais abarcarem a complexidade das estratégias de sobrevivências dos grupos indígenas, impõe-se que o ambiente democrático e de garantia de direitos legais tenha proporcionado a essa população, antes tornada “invisível”, seu reconhecimento legal, o que permitiu sua inclusão nesses estudos e estatísticas oficiais. Contudo a etnografia interessada nas formulações indígenas, e enfrentando os novos contextos de transformação da região, não nega as diferentes posições que os grupos interlocutores da pesquisa mantiveram diante da sociedade nacional ao longo de sua história, ora assumindo, é possível dizer, um papel mais integrado ora reivindicando suas distinções com relação aos não indígenas. Assim, o que a etnografia pretende discutir, também a partir dos números apresentados, são os matizes dessa composição indígena da cidade de Altamira, a partir das histórias familiares dos indígenas Xipaya e Kuruaya, de modo a refletir além de horizontes dualistas que reduzem essa população ou como indígenas em processo acelerado de destruição "virando brancos", ou em contrapartida, grupos com especial interesse no autorreconhecimento, "voltando a serem índios". Entre esses dois polos desdobram-se todas as tonalidades que compõem as experiências indígenas que envolvem os grupos residentes na cidade de Altamira.

Retomando o horizonte comparativo dos números absolutos da população indígena de Altamira, embora o método de contabilização dos estudos sejam de diferentes ordens (a maior parte das projeções populacionais, sem contar os Censos, refere-se ao total de famílias) 
observa-se o expressivo aumento da população indígena residente na cidade, como apresentado no quadro:

Tabela 2 - Levantamentos da população indígena na cidade de Altamira, PA.

\begin{tabular}{|c|c|}
\hline Ano e responsável por levantamento & População total \\
\hline $1988 *($ FUNAI e Eletronorte $)$ & 32 famílias \\
\hline $1991(\text { Censo })^{* *}$ & 211 pessoas \\
\hline 2000 (Censo) $^{* *}$ & 125 pessoas \\
\hline 1999 (Patrício-pesquisador) ${ }^{* * *}$ & 96 famílias/ 404 pessoas \\
\hline 2002* (FUNAI/AIMA) & 211 famílias \\
\hline 2006/2007*(AC Magalhães-pesquisador) & 207 famílias \\
\hline $2009 *($ Eletronorte $)$ & 340 famílias / 1622 pessoas \\
\hline $2010 * *$ & 877 pessoas \\
\hline 2011 (Norte Energia)**** & 505 famílias/ 1927 pessoas \\
\hline \multicolumn{2}{|l|}{ *Fonte: EIA Citadinos e Ribeirinhos da VGX, p.80 } \\
\hline \multicolumn{2}{|c|}{$\begin{array}{l}\text { **Fonte: Censos demográficos /situação de domicílio urbana (notando que o Censo de } 1991 \\
\text { incorpora indígenas de Altamira e Vitória do Xingu). } \\
\text { *** Estimativa presente na tese de mestrado de Patrício (2000) apenas dos Xipaya e Kuruaya. } \\
\text { **** População indígena atingidas pela Cota } 100 \text { da UHE-Belo Monte na zona urbana de Altamira (2012). }\end{array}$} \\
\hline
\end{tabular}

Assim, em termos populacionais os indicadores disponíveis já bastam para propor a relevância do estudo dos fenômenos demográficos dos grupos indígenas residentes na cidade de Altamira. Levando-se em conta o Relatório Final de Cadastro das Famílias Indígenas (NORTE ENERGIA, 2011) que corresponde ao universo amostral da sede municipal ${ }^{33}$ é possível também deduzir os múltiplos efeitos trazidos pela construção da usina (iniciada no ano de 2011) sobre demografia da população indígena em Altamira. O relatório também alude ao aumento da população indígena na área urbana, principalmente dos novos grupos étnicos, verificando a continuidade do padrão encontrado na Tabela 1.

Mesmo com esse aumento atrelado ao maior crescimento proporcional de novos grupos étnicos, o relatório conclui que a proporção dos grupos étnicos na cidade permaneceu semelhante ao dos estudos anteriores. Também sugere um aumento geral do número de

\footnotetext{
${ }^{33} \mathrm{O}$ estudo oriundo do cadastro fundamenta o monitoramento das famílias indígenas realocadas por conta da construção da UHE -Belo Monte, que compreende tanto a zona urbana como rural de Altamira. Alerta-se desde já que o cadastro censitário corresponde a apenas uma parcela da população indígena da cidade de Altamira.
} 
famílias indígenas ${ }^{34}$ em Altamira sem, contudo, poder afirmar a partir da comparação com os dados anteriores, por conta das diferentes metodologias censitárias utilizadas.

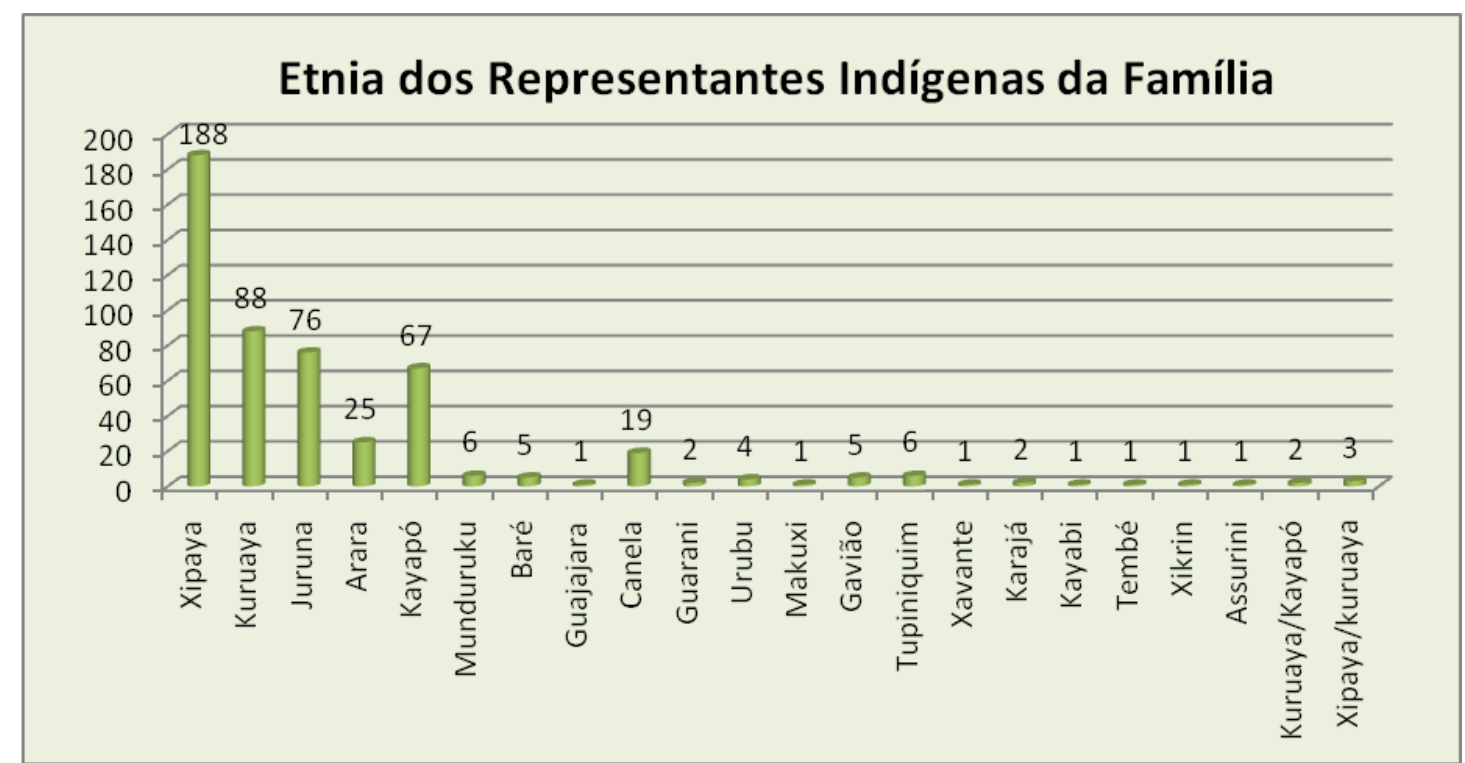

Figura 3 - Etnia dos representantes indígenas. Fonte: Relatório final de Cadastro das Famílias Indígenas (NORTE ENERGIA, 2012).

A despeito das diferenças metodológicas já indicadas, se compararmos os dados do gráfico acima com os da Tabela 1 observa-se um padrão muito semelhante tanto da proporção dos grupos étnicos sobre a população total de indígenas, como também se mantém o mesmo padrão de crescimento e diminuição das proporções de cada grupo étnico.

Tabela 3 - Evolução da proporção das etnias sobre a população indígena total na cidade de Altamira.

\begin{tabular}{|c|c|c|c|}
\hline Etnia & $\mathbf{2 0 0 2}$ & $\mathbf{2 0 0 9}$ & $\mathbf{2 0 1 1}$ \\
\hline Xipaya & 44,20 & 38,24 & 37,23 \\
\hline Kuruaya & 36,23 & 25,58 & 17,42 \\
\hline Juruna & 7,97 & 13,83 & 15,04 \\
\hline Kayapó & 5,80 & 6,17 & 13,27 \\
\hline Arara & 1,45 & 4,11 & 4,95 \\
\hline Outros & 4,35 & 12,07 & 12,08 \\
\hline
\end{tabular}

${ }^{34}$ Apesar do relatório não definir o que é uma família, deduz-se que está se reportando às declarações dos responsáveis pelas residências realocadas por Belo Monte, entrevistados durante o cadastramento. $O$ indicativo do número total de 505 famílias que residem em 433 moradias cadastradas condiz com a pressuposição indicada, o que corresponderia a 1,17 famílias por residência. 
Outro aspecto importante que os números revelam sobre as ocupações indígenas em Altamira refere-se à distribuição espacial da população nos bairros da cidade.

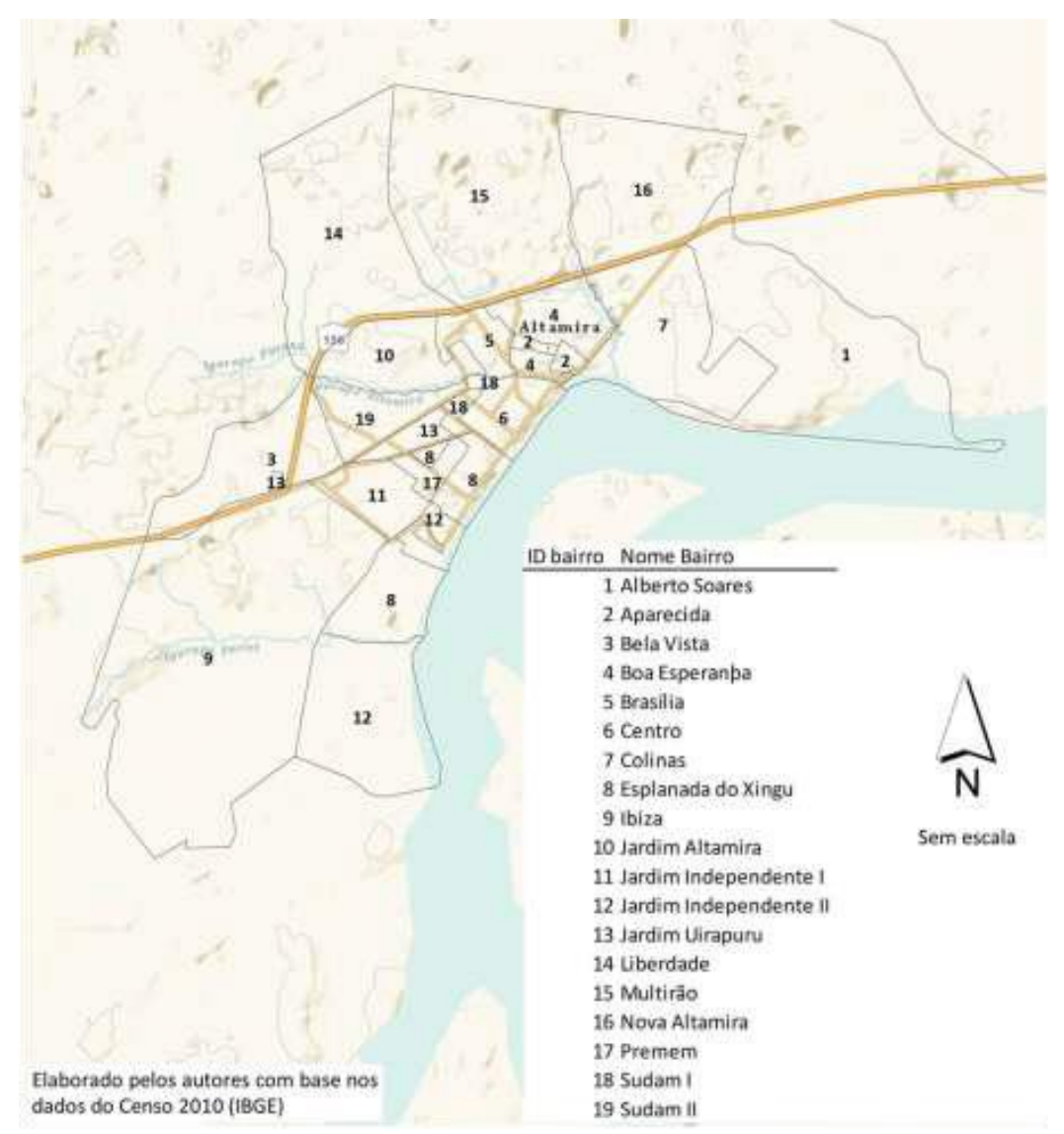

Figura 4 - Sede de Altamira - PA. Fonte: Simoni \& Dagnoni (2012).

Também nessa variável é preciso salientar as diferenças dos métodos de coleta, seja na consideração do universo amostral ou mesmo nas distintas formas de dividir o espaço urbano. O próprio uso das nomenclaturas dos bairros nos levantamentos não corresponde inteiramente em todos os casos, e isso é algo que pode ser percebido durante as conversas com os moradores que ainda se confundem com a nova reestruturação dos bairros da cidade. Essa redefinição foi aprovada pela Lei $\mathrm{n}^{\circ} 1.522$ de 16 de Dezembro de 2003, reduzindo o número de 32 bairros para 08 bairros. A Tabela 4 identifica as alterações correspondentes aos novos bairros, mas não é possível apresentar integralmente as correlações, pois muitos que aparecem não foram oficialmente discriminados em novos bairros. 
Tabela 4 - Distribuição da população indígena pelos bairros da cidade de Altamira.

\begin{tabular}{|c|c|c|c|c|c|c|}
\hline \multirow{2}{*}{ Bairro/ Ano } & \multicolumn{4}{|c|}{ Número de famílias } & \multicolumn{2}{|c|}{ Número de Pessoas } \\
\hline & 1988 & $1999 *$ & 2002 & 2009 & 2009 & 2010 \\
\hline São Sebastião (2) & 5 & 7 & 11 & 13 & 59 & \\
\hline Jardim Independente I (3) & 4 & 6 & 23 & 38 & 152 & 116 \\
\hline Jardim Independente II & 3 & 14 & 46 & 40 & 208 & 87 \\
\hline Aparecida (7) & 5 & 18 & 32 & 58 & 257 & 81 \\
\hline Boa Esperança (7) & & 15 & 30 & 23 & 116 & 140 \\
\hline Brasília (4) & 4 & 10 & 19 & 16 & 84 & 43 \\
\hline Açaizal & & 8 & 16 & 36 & 187 & \\
\hline Centro (1) & 5 & 12 & 11 & 21 & 96 & 129 \\
\hline Sudam I (1) & 2 & & 5 & 12 & 55 & 1 \\
\hline Sudam II & & & & & & 14 \\
\hline Jardim Oriente (2) & & & 4 & 2 & 6 & \\
\hline Mutirão (5) & & & 4 & 22 & 97 & 33 \\
\hline Liberdade (5) & & & 4 & 5 & 18 & 18 \\
\hline $\begin{array}{c}\text { Km } 4 \text { Altamira - Itaituba/ } \\
\text { Bela Vista }(3)\end{array}$ & & & 2 & 11 & 56 & \\
\hline Jardim Primavera (7) & & & 1 & 1 & 7 & \\
\hline Jardim do Sol & & & 1 & & & \\
\hline Esplanada do Xingu (2) & & & 1 & 2 & 9 & 58 \\
\hline $\begin{array}{c}\text { Alto da Brasília /Invasão } \\
\text { dos Padres }\end{array}$ & 2 & & 1 & 19 & 103 & \\
\hline Jardim Industrial & & 6 & & & & \\
\hline Ivalândia (4) & & & & 1 & 5 & \\
\hline Premem (2) & 2 & & & 1 & 2 & 4 \\
\hline São Domingos & & & & 8 & 44 & \\
\hline Colina do Forte (6) & & & & 5 & 17 & 8 \\
\hline Olarias & & & & 6 & 44 & \\
\hline Jardim Uirapuru (3) & & & & & & 4 \\
\hline Ibiza & & & & & & 12 \\
\hline Bela Vista (3) & & & & & & 29 \\
\hline Jardim Altamira (4) & & & & & & 7 \\
\hline Nova Altamira & & & & & & 35 \\
\hline Total & 32 & 96 & 211 & 340 & 1622 & 819 \\
\hline
\end{tabular}

Fontes: 1988 - Funai/Eletronorte; 1999 - Patrício, 2000; 2002 - Eletronorte/Funai. Cadastros das famílias indígenas residentes em Altamira - PA; 2009 - Eletronorte/Equipe V; Dados de 2010 referem-se ao questionário do Universo. Fonte: Tabela 3175 do Sidra/IBGE. *O levantamento de Patrício (2000) refere-se apenas aos Xipaya e Kuruaya.

(1) Bairro Centro: bairros Catedral, Cidade Velha, Recreio e Sudam I; 
(2) Bairro Esplanada do Xingu: bairros São Sebastião, Premem, Jardim Oriente e parte do Jardim Independente I;

(3) Bairro Uirapuru: bairros Bela Vista, Parque Ipê e Jardim do Estádio;

(4) Bairro de Brasília: bairros Jardim Altamira, Ivalândia e Tufi;

(5) Bairro Liberdade: bairros Mutirão, Progresso e Santa Ana;

(6) Bairro Colina do Forte: bairros Alberto Soares e $51^{\circ} \mathrm{BIS}$;

(7) Bairro Jardim Primavera: bairros Nossa Senhora, Aparecida e Boa Esperança

Na sequência apresentada podemos observar a progressão do número de famílias indígenas identificadas nos principais bairros de Altamira que abrigam e abrigaram essas populações ao longo do tempo. Os bairros historicamente identificados como ocupações dos grupos indígenas da cidade (principalmente dos Xipaya e Kuruaya), lembrados como as áreas do aldeamento religioso que deu origem à Altamira, mantêm-se como importantes locais de residência das famílias indígenas ao longo dos anos: São Sebastião, Jardim Independente I (atualmente abarcados pelo bairro Esplanada do Xingu) e Jardim Independente II juntos compreendem uma população de 264 indígenas segundo dos dados oficiais do Censo 2010, representando pouco mais de $32 \%$ do total de indígenas residentes na sede de Altamira. Contudo, se observarmos os outros levantamentos realizados, essa proporção de residentes sobre o total de famílias indígenas da cidade mantém-se significativa, mas apresenta uma tendência à redução: em 1988 era de 37,5\%; em 1999 era de 28,1\%; em 2002 era de 22,27\%; em 2009 era de 27,3\%. Segundo esses dados, em 2009 a proporção de famílias volta a ter um crescimento, que pode ter diversos significados, tanto relativos ao processo consolidado de reconhecimento dos indígenas moradores da cidade, como também da própria prosperidade desses grupos na cidade. Contudo, como indicado anteriormente, não é possível ter o controle comparativo total dos indicadores pois se tratam de estudos com metodologias e finalidades distintas. Ademais, tais estatísticas também corroboram para a percepção do fenômeno de crescimento e diversificação da população indígena na cidade que, nesse caso, ocorre com a extensão dos bairros de residência das famílias indígenas.

Acompanhando esse movimento percebemos um primeiro vetor de crescimento relacionado a ocupação das regiões dos igarapés Altamira e Ambé localizados ao norte da região central de Altamira, diferentemente das ocupações histórias da Missão ou Aldeinha (atualmente nas áreas dos bairros Esplanada do Xingu e Jardim Independente I e II) que situavam-se ao sul do centro da cidade, próximo à orla do Rio Xingu e do Igarapé Panelas. 
Segundo dados do Censo 2010 os bairros que compreendem essa região (Aparecida, Boa Esperança e Brasília) mantém uma população indígena que corresponde a cerca de $33 \%$ sobre total dessa população na cidade. A importância dessa região com relação à residência das famílias indígenas já pode ser sentida quando observamos o crescimento apresentado pelos estudos citados. Segundo Patrício (2000), essa segunda ocupação sistemática de famílias indígenas nesses bairros (que incluía o antigo bairro Açaizal) relaciona-se às transformações trazidas pela consolidação da Rodovia Transamazônica. Nesse padrão de ocupação vislumbra-se a periferização ${ }^{35}$ dessas comunidades, ou seja, seu expansivo afastamento das áreas centrais da cidade, em direção às regiões de várzea e áreas sujeitas à alagamentos periódicos, conhecidas como "baixões":

\begin{abstract}
"Quanto a posição dos bairros em questão, é possível observar que os mesmos se encontram em pólos opostos - relação periferia x periferia - porém, quando fazemos a leitura dos dois em relação ao centro da cidade, observamos que os mesmos convergem para esse centro - relação periferia $\mathrm{x}$ centro. Além disso, quando visualizamos a planta da cidade, identificamos o sentido do crescimento dela de forma oposta à localização dos bairros, o que implica em um não investimento em políticas públicas nos mesmos". (PATRICIO, p. 84, 2000)
\end{abstract}

Também é preciso destacar a incorporação de algumas famílias indígenas à região central da cidade, um processo que também foi marcado pelo crescimento. Nesse sentido pode-se concluir que muitas dessas famílias, há muito tempo residentes na cidade Altamira, acabaram por ter acesso a regiões que hoje em dia sofrem com a especulação imobiliária, como é caso dos próprios bairros da Esplanada do Xingu e Jardim Independente I e II. Assim, os dados do Censo 2010 indicam que a população indígena residente no centro de Altamira corresponde a cerca de $16 \%$ da população indígena total da cidade.

Finalmente, um terceiro processo de expansão das áreas de localização das famílias indígenas corresponde à intensificação do processo de periferização, direcionando o crescimento para as áreas distantes do centro e atravessando o traçado da Rodovia Transamazônica em direção noroeste e sudoeste da região central, regiões distantes da orla do Rio Xingu, para onde se orienta o crescimento da cidade como um todo. Assim os bairros de

\footnotetext{
${ }^{35}$ Durante o texto serão apresentados alguns dados que caracterizam condições socioeconômicas dos moradores indígenas da cidade que indicam a situação de vulnerabilidade dessa população. Contudo assim como outros, não foi possível ter acesso à informações integrais a esse respeito.
} 
Bela Vista, Mutirão, Jardim Altamira, Liberdade e Nova Altamira mantém cerca de $15 \%$ de toda a população indígena da cidade.

Observando os dados sobre a territorialização das populações indígenas em Altamira constantes no Relatório de Cadastramento das Famílias Indígenas (Norte Energia, 2011) temos um elemento particular para compreensão dessa espacialização. Como foi dito, a natureza do cadastro correspondia à necessidade de identificação dos indígenas residentes nas áreas da cidade que serão alagadas pelo reservatório da usina de Belo Monte, ou seja, a população indígena que terá de ser realocada. Visto esse viés, temos um censo relacionado às áreas de risco, beiras de igarapés e baixadas alagadiças que estão na chamada Cota 100 (áreas abaixo dos 100 metros de altitude, margem de risco calculada para o total enchimento do reservatório). Portanto temos a seguinte distribuição das famílias, segundo o critério utilizado pelo

Relatório: 
Tabela 5 - Distribuição das famílias indígenas nos setores da cidade de Altamira por etnia.

\begin{tabular}{|c|c|c|c|c|c|c|c|c|c|c|c|c|c|c|c|c|c|c|c|c|c|c|c|}
\hline \multirow[b]{2}{*}{ Setores } & \multicolumn{23}{|c|}{ Etnia dos Representantes Indígenas da Família } \\
\hline & 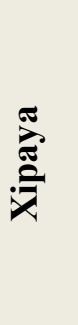 & 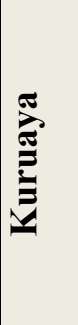 & 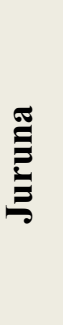 & 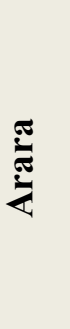 & | & 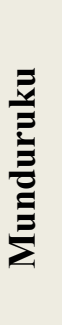 & 节 & 荀 & 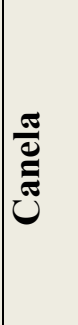 & 馬 & है & 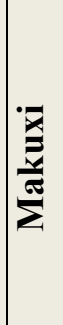 & שَّ & 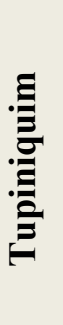 & 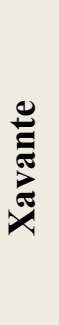 & 譪 & 䓂 & $\begin{array}{l}\stackrel{\bullet}{\mathrm{E}} \\
\stackrel{\mathrm{E}}{\mathrm{E}}\end{array}$ & $\frac{\Xi}{\bar{x}}$ & 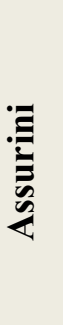 & 总 & 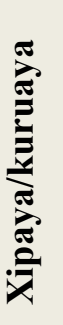 & 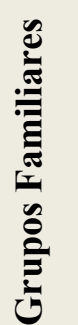 \\
\hline Igarapé Ambé & 101 & 61 & 43 & 13 & 56 & 3 & 5 & 1 & 14 & 2 & 3 & 1 & 2 & 1 & 1 & 1 & 0 & 0 & 1 & 1 & 2 & 0 & 312 \\
\hline Igarapé Altamira & 63 & 16 & 30 & 11 & 11 & 2 & 0 & 0 & 5 & 0 & 1 & 0 & 3 & 5 & 0 & 0 & 1 & 1 & 0 & 0 & 0 & 0 & 149 \\
\hline Igarapé Panelas & 22 & 10 & 3 & 0 & 0 & 1 & 0 & 0 & 0 & 0 & 0 & 0 & 0 & 0 & 0 & 1 & 0 & 0 & 0 & 0 & 0 & 3 & 40 \\
\hline Orla do Xingu & 2 & 1 & 0 & 1 & 0 & 0 & 0 & 0 & 0 & 0 & 0 & 0 & 0 & 0 & 0 & 0 & 0 & 0 & 0 & 0 & 0 & 0 & 4 \\
\hline Total & 188 & 88 & 76 & 25 & 67 & 6 & 5 & 1 & 19 & 2 & 4 & 1 & 5 & 6 & 1 & 2 & 1 & 1 & 1 & 1 & 2 & 3 & 505 \\
\hline
\end{tabular}


De imediato observa-se que a nomenclatura para identificação das áreas atingidas pelo reservatório de Belo Monte não utiliza a distribuição por bairros e sim por setores, que por sua vez são definidos à partir dos cursos d'água que servem o território municipal, os igarapés e o rio Xingu. Com isso podemos apenas situar essas regiões que englobam vários bairros e também não compreendem suas áreas integralmente, embora essa classificação seja mais próxima do que é o padrão nativo de ocupação dessas áreas. Como foi aludido anteriormente, as famílias indígenas passaram a ocupar áreas alagadas de várzea, seguindo o curso dos igarapés, no movimento de interiorização, movendo-se das residências mais próximas da beira do rio, área que passou a ser assediada pelo mercado imobiliário. Assim temos as regiões dos igarapés Altamira e Ambé (que correspondem aproximadamente aos bairros de: Brasília, incluindo a região conhecida como Invasão dos Padres; Aparecida; Boa Esperança; Mutirão; Nova Altamira e Colina do Forte). Essas, então, são regiões com grande densidade de famílias indígenas como pôde ser visualizado pelas estatísticas até agora apresentadas. Os números do relatório corroboram com essa constatação: as regiões do Igarapé Altamira e Ambé mantêm um montante de 461 famílias indígenas, o que corresponde a mais de $90 \%$ do total de famílias cadastradas. Essa expressiva proeminência desses bairros acontece pois são as regiões mais baixas da cidade, portanto essa situação não pode ser estendida para toda a cidade, pois, como foi visto, as regiões dos bairros Esplanada do Xingu e Jardim Independente I e II permanecem como importantes territórios ocupados pelos indígenas. Assim alerta o relatório:

\footnotetext{
"Entretanto, cabe ressaltar que pode ser equivocada a análise de esvaziamento de famílias indígenas nos bairros que antes havia maior concentração, como Independente I e II (antigo São Sebastião) localizados no Igarapé Panelas. Quando consideramos a representação das etnias pelos bairros que compõe os igarapés, não podemos esquecer que a Cota 100 no Igarapé Panelas não atinge nem $10 \%$ dos bairros mencionados acima, ficando apenas afetado uma pequena faixa bem próxima ao Rio Xingu" (Norte Energia, 2011, p. 26).
}

Consideradas essas limitações do levantamento, pode-se avançar sobre outras contribuições que ele oferece para situarmos aspectos das condições dos indígenas moradores de Altamira. A correlação entre as áreas de residência e as etnias é um indicador interessante que agrega possíveis entendimentos sobre as migrações e crescimento da população indígena de Altamira. A Tabela 6, a seguir, apresenta a proporção das etnias sobre o total de famílias indígenas residentes nos setores do cadastro: 
Tabela 6 - Proporção das etnias sobre o total de famílias indígenas residentes nos setores de Altamira PA.

\begin{tabular}{|c|c|c|c|c|c|c|}
\hline \multirow{2}{*}{ Setor/Etnia } & \multicolumn{6}{|c|}{ Proporção das etnias por setores (\%) } \\
\cline { 2 - 7 } & Xipaya & Kuruaya & Juruna & Arara & Kayapó & Outros \\
\hline $\begin{array}{c}\text { Igarapé } \\
\text { Ambé }\end{array}$ & 32.37 & 19.55 & 13.78 & 4.17 & 17.95 & 12.17 \\
\hline $\begin{array}{c}\text { Igarapé } \\
\text { Altamira }\end{array}$ & 42.28 & 10.74 & 20.13 & 7.38 & 7.38 & 12.08 \\
\hline $\begin{array}{c}\text { Igarapé } \\
\text { Panelas }\end{array}$ & 55 & 25 & 7.5 & 0 & 0 & 12.5 \\
\hline $\begin{array}{c}\text { Orla do } \\
\text { Xingu }\end{array}$ & 50 & 25 & 0 & 25 & 0 & 0 \\
\hline
\end{tabular}

Levando-se em conta a distribuição dos grupos étnicos nas regiões referidas, observase um padrão muito semelhante ao que ocorre na cidade como um todo, a prevalência do grupo Xipaya em todos os setores. Quando consideramos os Kuruaya, existe uma ligeira distinção do padrão geral com relação a área do Igarapé Altamira, ao abrigar uma percentual de famílias de $10,74 \%$, abaixo da média de $25,00 \%$ observada no contexto de toda cidade. Em contrapartida tem-se uma população Juruna de 20,13\%, bem acima da média de $12 \%$ encontrada para toda a cidade. É difícil compreender essa situação a partir desses dados pois, como foi dito, trata-se de um cadastro censitário com um objetivo específico. Contudo, trazendo o comparativo com os números apresentados para as regiões do Igarapé Panelas e da Orla do Xingu, onde se tem uma proporção claramente maior para os Xipaya e os Kuruaya, e uma proporção abaixo da média para os Juruna, tem-se indicativos do modo pela qual se processou a ocupação nessas regiões. Retomando a etnografia do Capítulo 2, onde os grupos Xipaya e Kuruaya sustentam os relatos históricos abordados sobre a formação do bairro Missão, Aldeinha ou bairro das Onças - atualmente regiões que abrangem os bairros Esplanada do Xingu e Jardim Independente I e II -, denota-se a posição que os grupos Xipaya e Kuruaya tiveram nesse processo histórico que consolida-se em meados do século XX. Essa região recebeu grandes contingentes dos Xipaya e dos Kuruaya que desciam o Rio Xingu em direção a cidade de Altamira, após o declínio do segundo ciclo da borracha. Essa conjuntura ainda mantém sua marca com uma expressiva população Xipaya e Kuruaya nessa regiões de 
Altamira. Note-se, inclusive, que dos quatro indígenas cadastrados como "outros" no setor do Igarapé Panelas, três se auto-identificam Xipaya-Kuruaya ${ }^{36}, 7,5 \%$ dos cadastrados, o que contabiliza um total de 87,5\% para os Xipaya e os Kuruaya nesse setor. O mesmo vale para Orla do Xingu onde dos quatro cadastrados, dois são Xipaya e um Kuruaya.

Sobre o expressivo número Juruna nas regiões dos igarapés Ambé e principalmente Altamira é necessário indicar que a área total que corresponde o setor do Altamira é bem menor do que a do Ambé. Também devemos lembrar que essas são regiões do segundo processo de ocupação sistemática dos bairros de Altamira por indígenas. Feitas as considerações é preciso lembrar que os Juruna são indicados como os primeiros moradores de Altamira, sendo o principal grupo que ocupava essa região até o aldeamento jesuíta do século XVIII estabelecer a Missão Tavaquara, e também a principal população reunida nas missões que se estabeleceram subsequentemente na região (Adalberto, 1977). Tendo tido um longo processo de contato com os não indígenas da região é notável que se encontre uma expressiva população dos Juruna que se manteve na região situada na Volta Grande do Xingu ${ }^{37}$, abaixo de Altamira. Embora a etnografia não tenha se focado nesse grupo, notou-se que sua baixa presença nas áreas da antiga Missão, está relacionada a esse processo de estabelecimento em outras regiões de Altamira. No caso do grande número de famílias Juruna no setor do igarapé Altamira seria necessário analisar as trajetórias individuais para a compreensão dos eventos de mudança e migração fundamentais, para melhor entendimento do fenômeno como um todo.

O grande número de famílias Kayapó ${ }^{38}$ que mora no setor do Igarapé Ambé é outra situação digna de nota. Com uma população que também apresenta um crescimento expressivo, a residência dos Kayapó na cidade de Altamira remonta ao período pós “pacificação" já no final dos anos de 1950. Depois, com a Rodovia Transamazônica essa migração se potencializou (Patrício, 2000). Da mesma forma seria preciso compreender as questões de cada morador Kayapó, bem como os traços recorrentes nessas histórias para

\footnotetext{
${ }^{36}$ A identificação Xipaya-Kuruaya será discutida adiante, nos contextos em que a etnografia se defrontou com suas implicações. Contudo, nesse momento, a identidade Xipaya-Kuruaya pode ser explicada pela condição histórica que marcou os dois grupos, que mantiveram muitos casamentos a partir da época em que se reuniram na região do rio Xingu e seus afluentes, rio Iriri e rio Curuá. Ver Capítulo 2.

${ }^{37}$ Nessa região estão as Terras Indígenas Paquiçamba, além dos ribeirinhos Juruna, como é caso de moradores da Ilha da Fazenda e da Aldeia São Francisco. Cumpre lembrar também da TI Juruna do Km 17, já em direção à estrada que leva ao município de Vitória do Xingu.

${ }^{38}$ Os dados não estratificam quais grupos Kayapó estão se referindo, mas haja vista a proximidade, e comparando com as evidências coletadas em campo, pressupõe-se que se originem dos grupos Xikrin e também Kararaô.
} 
termos alguma noção desse processo. Contudo, o relatório indica que as famílias Kayapó, que aumentaram no cadastramento de 2011, se originam em sua maioria da TI Trincheira Bacajá.

Os dados apresentados ajudam a situar alguns aspectos das condições em que estão os indígenas moradores de Altamira. Nessa apresentação inicial priorizou-se a análise de estatísticas sobre a demografia indígena de Altamira, sem perder de vista que todo trabalho está fundamentado pela perspectiva etnográfica, da qual, por sua vez, foram apontadas algumas questões de interesse durante o segundo capítulo, indicando a discussão teórica que se pretende realizar. As propostas contidas na etnografia servem-se dos dados apresentados anteriormente tanto para contextualização dos grupos indígenas interlocutores da pesquisa quanto para se pensar sobre as condições sociopolíticas sobre as quais esse conhecimento está alicerçado. Significa dizer que os dados produzidos revelam não apenas um recorte de pesquisa sobre as populações indígenas da cidade de Altamira, como estão também eles mesmos implicados nas condições sociais as quais estas populações se submeteram ao longo desses anos. Assim quando observamos o crescimento da população indígena de Altamira existe aí uma série de camadas de significados que explicam o fenômeno, não apenas relativos às áreas de conhecimento específicos, como por exemplo análises demográficas ou explanações sociológicas, mas que também são capazes de transformar a própria ordem desses conhecimentos. $\mathrm{O}$ aumento numérico dos indígenas de Altamira pode ser tanto efeito das políticas de reconhecimento étnico do Estado brasileiro (o que permitiu a categoria indígena se consolidar nos censos demográficos) como também fruto de estratégias de sobrevivência dessas populações que sofreram o aniquilamento pelas políticas de integração, ou mesmo o preconceito e discriminação por parte dos não indígenas locais durante um longo tempo. Sobre o segundo, cabe especular o quanto a permanência na cidade, embora tenha alterado significativamente o modo de vida desses grupos permitiu novas possibilidades que contribuíram para seu incremento demográfico, passando a servir mesmo como espaço afirmativo de resistência populacional. Na presente problematização a correlação só pôde permanecer como hipótese, sendo que caberá ao relato etnográfico captar alguns sentidos das experiências indígenas na cidade que permitam acrescentar substância aos dados sobre o crescimento populacional. Para a dissertação, os dados numéricos foram mobilizados à medida que puderam ser "lidos etnograficamente", ou seja, assim como as fontes históricas 
consultadas, aqui o problema versa menos sobre a capacidade estatística ${ }^{39}$ dos dados do que sobre seu potencial elucidativo para questões antropológicas: os números são capazes de sedimentar, quando criticamente situados, as questões propostas por meio da experiência etnográfica compartilhada com os interlocutores da pesquisa. O que se segue na dissertação irá reforçar essa proposta acompanhada então da caracterização dos bairros que se constituíram como o fio condutor para o estudo. Realizando uma leitura etnográfica das paisagens urbanas e suas dobras e lançando mão novamente de uma apreciação orientada dos dados estatísticos existentes, a dissertação percorre as sugestões formuladas nos diálogos com os interlocutores da pesquisa que versam sobre espaços, fazeres e afetos.

\subsection{Os indígenas na cidade Altamira: deslocamentos e transformações}

Partindo dos elementos oferecidos pela análise dos dados populacionais sobre indígenas moradores da cidade de Altamira apresentada anteriormente, destacando os aspectos que permitem visualizar a distribuição espacial dos principais grupos étnicos que compõem esse universo populacional urbano na Amazônia, é possível vislumbrar processos de construção dos espaços constituintes da vida social entre indígenas e não indígenas na cidade e sua rede de relações. Embora o presente trabalho não se debruce intensamente sobre os modos de produção das experiências indígenas na cidade partindo da relação com e no espaço como eixo de análise, é preciso levar em conta, dentro da proposta analítica defendida, a importância das reflexões em torno da situação territorial, e para além dessa, dos significados que os espaços vividos e percorridos pelos interlocutores da pesquisa interpelam suas histórias e organizações sociais. Significa dizer que, se a proposta analítica privilegia as questões que remetem ao encontro de modelos diacrônicos e sincrônicos (memórias e redes de parentesco, por exemplo), permitidos e pensados pela etnografia, a mesma impõe "o lugar do lugar”, não apenas como efeito do ambiente experimentado pelas migrações dos grupos ou nas formas das trajetórias pessoais, por exemplo, mas como fator produzido e de produção de relações que se desdobram nas experiências dos interlocutores da pesquisa. Assim, assume-se que o conceito de redes de mobilidades espaciais dos indígenas moradores de Altamira, para além de perpassar "causos" e "encontros", substâncias fundamentais para o relato etnográfico

\footnotetext{
${ }^{39}$ Isso não significa que o rigor estatístico não seja importante para a etnografia, uma vez que essa proposta só faz sentido com a garantia de dados fidedignos.
} 
proposto, tem seu valor intrínseco, revelado nas discussões a seguir, sem contudo, mais uma vez alertando, ser a perspectiva dominante no presente trabalho.

Falar sobre territorialidade para os grupos indígenas urbanos contêm problemas próprios às permanências que a categoria "indígena" mantém nas diversas instâncias em que é reivindicada, e especialmente verificada pela evidente dificuldade das instituições governamentais em reconhecer os direitos dessa população, tendo em vista que o direito a terra é considerado como principal garantia de soberania desses povos. Embora o conhecimento antropológico há muito tenha superado a essencialização da relação entre grupo étnico e território, é imprescindível, como foi ressaltado anteriormente, a compreensão dos modos como as populações produzem e ocupam os espaços. É nesse momento que a condição urbana dos indígenas esbarra nas limitações do instrumental analítico, fazendo todo estudo sobre populações indígenas urbanas parecer exploratório, a despeito de sua ampla difusão nas produções acadêmicas atuais. Mesmo que a presença de indígenas nas cidades brasileiras não seja uma situação nova, a questão vem sendo retomada por meio de novas problematizações que ajudam a compreender os novos significados desses fenômenos que tem em comum a incorporação das práticas, por assim dizer indígenas, na tessitura característica do universo urbano. Portanto, o movimento da antropologia contemporânea que refresca a análise desses fenômenos sobre indígenas em situações urbanas converge para uma proposta de abordagem do problema que recusa explicações que apelam para terminologias e conceitualizações anteriores ao comprometido estudo dessas manifestações, assumindo com seriedade os significados dessa presença que, por sua vez, estão atrelados a novos contextos sociopolíticos. Correspondem então a uma gama de propostas etnográficas capazes de sugerir outros esquemas de apreensão sobre processos de urbanização, como o que ocorre nas cidades amazônicas, por exemplo, aproximando-se dos pontos de vista das populações estudadas. Como observa Nunes (2010): "Mas toda esta parte é também uma tentativa de resposta um pouco mais elaborada a esse imaginário, reafirmando que dicotomias como "índios de (na) reserva/aldeia" vs. "índios urbanos" faz tão pouco sentido como outras como índios “aldeados" vs. "desaldeados/aculturados", etc".

O livro pioneiro de Cardoso de Oliveira (1968), Urbanização e tribalismo: a integração dos índios Terêna numa sociedade de classe, foi uma grande referência na antropologia brasileira que introduziu esse debate também desfazendo certas preconcepções sobre indianidade (que continuam marcando o imaginário nacional), e ao mesmo tempo discutindo com as elaborações antropológicas que durante muito tempo explicaram a situação 
desses indígenas por meio da perda cultural, em que o processo de aculturação é sempre observado como destruição, adquirindo um valor intrinsecamente negativo ${ }^{40}$. No pensamento de Cardoso de Oliveira a crítica às noções de tribalismo e aculturação se estruturam mediante a exposição das relações interétnicas situadas nessa territorialidade particular que é o contexto urbano em que estão postos os Terena: “A ideia da 'persistência' da Aldeia na Cidade deve ser entendida como a manutenção dos elos tribais nas condições de vida urbana" (1968, p. 210). Avançando analiticamente dessa proposta, o que é classificado como "elos tribais" por Cardoso é revisto pelos novos estudos que estão menos preocupados com as reminiscências e mais próximos de construir formas de apreensão compartilhadas com seus interlocutores. Essa guinada pode ser observada em autores que assumiram o problema da "integração", aqui pensada em termos da habitação na cidade, como uma questão proposta por essas populações e não apenas sob o viés da constituição do que é urbano, ou da formação da sociedade nacional, por exemplo. Mesmo que o problema da urbanização nessas cidades amazônicas com presença indígena corresponda ao dilemas da absorção dessas populações mediante a estrutura social segregadora e discriminatória, era preciso voltar atenção aos modos como os próprios sujeitos qualificavam suas práticas e concepções sobre esse processo.

As interessantes e instigantes etnografias de Andrello (2006:447) e Lasmar (2005:285) sobre grupos indígenas localizados na bacia do rio Negro se inserem nesse horizonte ao disponibilizar descrições em que os elementos considerados tipicamente urbanos são mobilizados no cotidiano das diversas populações indígenas que se relacionam tanto no povoado de Iauaretê como na cidade de São Gabriel da Cachoeira. Essas redes de relações no espaço urbano são detalhadamente consideradas e discutidas por intermédio do diálogo com os modos de apreensão dos moradores indígenas. Para Lasmar:

"Isso implicava uma recusa da oposição tradicional/moderno e uma aposta na
importância de discernir o que há de especificamente indígena nos processos
analisados. Em suma, implicava a opção de privilegiar radicalmente o ponto
de vista dos índios sobre o mundo e a vida social". (LASMAR, p. 256, 2005).

Embora seja necessário matizar as diferenças etnográficas, sejam relativas aos desenvolvimentos históricos específicos, ou às experiências urbanas particulares a cada contexto, por exemplo, salienta-se como tais projetos etnográficos sustentam as inclinações

\footnotetext{
${ }^{40}$ Para uma provocação sobre os usos da noção de aculturação fica indicada a entrevista de Peter Gow à Marta Amoroso e Leandro Mahalem, “A aculturação é um objeto legítimo da antropologia” (2009:19).
} 
delineadas pela presente discussão ao abordar a presença indígena na cidade. Essa perspectiva proporcionou as recentes tentativas de diálogo entre as questões da etnologia indígena e as contribuições da antropologia urbana, como sugerem os trabalhos desenvolvidos pelo Núcleo de Antropologia Urbana (NAU-USP) ${ }^{41}$ com a criação do Grupo de Etnologia Urbana $(\mathrm{GEU})^{42}$. As reflexões de Andrade (2012:192) sobre os Sateré-Mawé de Manaus, localizam nos argumentos de Magnani (2002:22) as contribuições da antropologia urbana para se pensar a presença indígena na cidade. Andrade retém da proposta de Magnani a distinção com relação às análises e respectivos diagnósticos que enfatizam os aspectos desagregadores do processo de urbanização. Assumindo a perspectiva de que o urbano não é o espaço da dissolução da diversidade cultural, Andrade pôde recuperar as críticas aos modelos de apreensão das manifestações de identificação étnicas, que promovem a problematização dos conceitos de cultura em sua discussão. Cabe notar que essas reflexões estão próximas da presente proposta de pesquisa, revendo os modos como as teorias do contato e da etnicidade abordam a presença indígena nas cidades, um movimento que persegue as relações e considerações nativas, problematizando as categorias tanto de urbano como de indianidade ${ }^{43}$.

Tomadas algumas implicações da discussão antropológica sobre a presença indígena na cidade, a dissertação segue na proposta de apresentar certos dados quantitativos que complementam as indicações referentes à distribuição da população indígena na cidade, mais uma vez como forma de problematizar as questões que o relato etnográfico teve que enfrentar nesses contextos. Finalmente essa apresentação irá permitir à dissertação refletir sobre a natureza desses conhecimentos implicados nas situações vividas pelos interlocutores e compartilhadas com o pesquisador.

\footnotetext{
$* * *$

${ }^{41}$ O NAU-USP é um grupo de pesquisa e discussões, coordenado pelos professores José Guilherme C. Magnani e Alexandre Pereira, com interesse nas dinâmicas, suas formas de sociabilidade e instituições e equipamentos urbanos.

42 Coordenado José A. D. de Andrade o grupo foi criado a partir de pesquisas desenvolvidas nas cidades amazônicas. O grupo discute as redes de socialidade da população indígena em suas cidades por meio da interface entre a Antropologia Urbana e a Etnologia, e também com contribuição da História e da Arqueologia.

43 Contudo, é preciso salientar mais uma vez, que os contextos etnográficos abordados por tais trabalhos guardam importantes diferenças com relação a presente etnografia, traduzidas pelas distintas formulações e questões em torno da experiência na cidade oferecidas pelos interlocutores das pesquisas.
} 
Conforme foi observado anteriormente, as regiões da cidade de Altamira com marcante presença de população indígena correspondem a determinados bairros que configuraram-se mais ou menos periféricos em relação ao centro da cidade. Embora as famílias indígenas ocupem cada vez mais outros bairros da cidade, os dados apresentados permitiram observar duas importantes regiões de residência para os indígenas na cidade: os antigos bairros ao sul da região central, indo até o Igarapé Panelas (Esplanada do Xingu e principalmente Jardim Independente I e II - antigos Muquiço e Missão); e as ocupações mais recentes ao norte do centro da cidade entre os Igarapés Altamira e Ambé, cuja consolidação remete-se ao período pós Rodovia Transamazônica (Aparecida, Boa Esperança e Brasília). Ambas regiões estão próximas às margens do Rio Xingu sendo que as ocupações acompanham as várzeas dos igarapés, principalmente na região do Ambé e Altamira. Como foi indicada, a condição de residência dos indígenas da cidade é caracterizada pela vulnerabilidade social, vivendo nas periferias de Altamira, em áreas com incipiente infraestrutura urbana e condições de moradia precárias. Observando alguns dados disponíveis no EIA/RIMA “Componente dos Indígenas Citadinos e Ribeirinhos da Volta Grande do Xingu” (ELETRONORTE, 2009) sobre a condição socioeconômica das 340 famílias indígenas recenseadas, tem-se que mais de $66 \%$ das moradias são abastecidas por poço e $28 \%$ pela rede geral; quase $64 \%$ tem o esgoto coletado por fossa e $30 \%$ fica a céu aberto; mais de 93\% tem energia elétrica em casa; e quase $80 \%$ tem o lixo doméstico coletado. Os números sugerem aquilo que está posto abertamente na propaganda que veicula as contrapartidas positivas oferecidas pela construção da UHE - Belo Monte: a reestruturação urbana nas regiões de palafitas da cidade, destacando a meta de atingir $100 \%$ de coleta e tratamento de esgoto em toda a cidade ${ }^{44}$. Também como apresenta Patrício (2000) em sua dissertação de mestrado, as residências das famílias Xipaya e Kuruaya nos bairros de sua pesquisa foram caracterizadas pelo padrão arquitetônico, nomeado pela autora como "arquitetura da urgência" e de madeira:

\footnotetext{
"Construções que se constituem de uma estrutura retangular erguida com tijolo maciço artesanal de adobe em reboco que consiste em uma "aguada" de cimento e as divisões de madeira. Essas casas, algumas construídas geminadas com a outra, irão compor o que chamam de "vila". Tais moradias estão abaixo do padrão regulamentar mínimo de uma habitação que é de 2,5 metros de pé direito, o que significa pouca circulação de ar, abafamento e
}

${ }^{44}$ Mais a frente serão discutidas transformações trazidas pelas interferências de Belo Monte, criando expectativas entre os interlocutores relacionadas principalmente às contrapartidas socioambientais prometidas pelo empreendimento. Até o momento a maioria dessas promessas não foram cumpridas, e muitas deles já não tem perspectiva de serem executadas. Ver: ISA, 2015. 
falta de saneamento básico; e casas [de madeira] com assoalho no chão ou assoalho alto, isso quando são construídas nos lugares que enchem ou ficam alagados. Apresentam os mesmos padrões de saneamento que as de adobe" (PATRÍCIO, p. 85, 2000).

Sobre os Juruna da cidade Saraiva (2005) indica o mesmo padrão construtivo, contudo indicando uma predominância de moradias nos bairros mais recentes, do eixo em direção à Rodovia Transamazônica:

"Em Altamira, as famílias são distribuídas nos bairros de Aparecida, Acesso, Açaizal e Bela Vista. Esses bairros caracterizam-se por localizaram-se nas áreas periféricas. As casas revelam a condição social dos ocupantes: são simples, de madeira algumas com assoalho e outras de chão batido, chegando a maioria a alagar no inverno com a enchente do rio". (SARAIVA, p. 115, 2005)

Tomando os dados sobre condição das moradias do Projeto de Cadastro Socioeconômico das Famílias Indígenas moradoras da cidade de Altamira e da Volta Grande do Xingu (2012) referente às propriedades cadastradas no Setor do Igarapé Panelas e Orla do rio Xingu (aproximadamente as áreas dos bairros onde a presente pesquisa iniciou sua análise - regiões históricas da ocupação indígena de Altamira) tem-se um quadro bastante próximo ao já apresentado para o universo citadino como um todo. Segundo o relatório, das $58^{45}$ famílias cadastradas nesse setor mais de $93 \%$ tem acesso à rede geral de energia elétrica; cerca de $47 \%$ tem a casa construída de alvenaria (tijole/adobe) e pouco mais de $43 \%$ de madeira; a maior parte das casas tem revestimento do piso - $26 \%$ cerâmico, $33 \%$ de madeira e $35 \%$ de cimento -, sendo que apenas $4 \%$ tem chão de terra; mais de $93 \%$ das casas tem cobertura de telha de amianto; mais de $70 \%$ tem instalação sanitária dentro de casa, sendo a forma de saneamento feita na maior parte das casas por fossa rudimentar - pouco mais de $77 \%$ - e quase $20 \%$ das residências mantendo vala negra ou não abrigando qualquer tipo de instalação; quase $88 \%$ das residências é abastecida por poço e pouco mais de $6 \%$ recebem água da rede geral; quanto ao destino do lixo, quase $90 \%$ da residências tem coleta por serviço de limpeza sendo o restante queimado ou jogado em terreno baldio/logradouro.

\footnotetext{
${ }^{45} \mathrm{O}$ cadastro total corresponde a 70 famílias, contudo esses dados foram coletados apenas em 58 propriedades cadastradas.
} 
Tais signos da ocupação residencial dos indígenas na cidade de Altamira remetem ao modo geral da integração de populações indígenas nos meios urbanos brasileiros, cuja equação resulta na pauperização desses grupos, situados à margem do processo de urbanização, o que na Amazônia configura-se pela alusão a situação das palafitas, versões das periferias e favelas conhecidas do referencial sulista brasileiro. Essa representação, de fundo tangível, repercute não apenas o modo com que conhecimentos (tais como todos aqueles reunidos sob o rótulo de ciência) concebem os indígenas em meio urbano, mas também está implicada nas próprias formas indígenas de atuar e pensar sobre suas condições. Ao operarmos com esses indicadores temos elementos comuns à população pobre da cidade de Altamira, o que permite equilibrar indígenas e não indígenas em termos socioeconômicos, por assim dizer. Patrício (2000) menciona os processos de transformação por que passaram os indígenas residentes no bairro de São Sebastião (Muquiço):

"As casas no bairro São Sebastião tomaram um novo tipo de ordenação, na medida em que a cidade crescia e havia a necessidade das ruas serem abertas. As casas com telhado de palha e parede com cipó e adobe foram substituídas aos poucos por casas de madeira ou tijolo maciço artesanal, com telhado de barro ou ainda de brasilit" (PATRÍCIO, p. 85, 2000).

Observando a situação do bairro São Sebastião (antigamente chamado Muquiço, e que hoje consiste em uma rua do bairro Esplanada do Xingu que será em parte alagada pelo reservatório de Belo Monte), temos um outro processo de transformação urbana advindo de sua privilegiada localização no contexto de desenvolvimento atual da cidade. Situado próximo à região central da cidade, ao lado do campus da Universidade Federal do Pará (UFPA), o bairro é caracterizado por dois tipos construtivos distintos: residências majoritariamente em madeira, na porção que margeia o rio Xingu - palafitas que garantem a permanência nas casas durante os períodos de cheia do rio e que por sua vez deverão ser retiradas pois serão atingidas pelo reservatório da usina -; e as casas que ficam do outro lado da única rua do bairro, com espectro construtivo mais amplo, geralmente de alvenaria, contudo com padrões de ocupação variados, conforme pode ser observado nas imagens a seguir: 


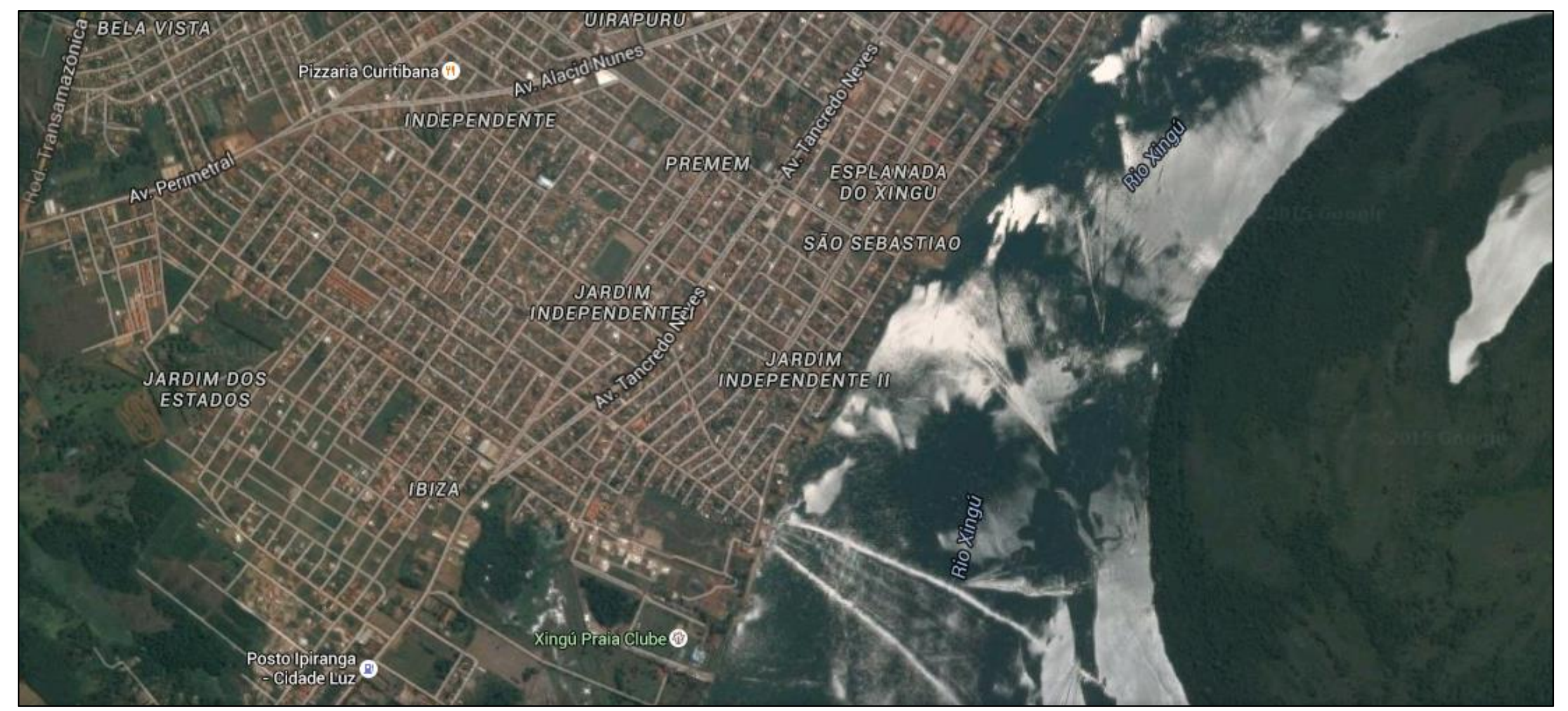

Figura 5 - Vista aérea da região do bairro do Muquiço (São Sebastião) e Jardim Independente I e II - Fonte: Google Maps (2015). 


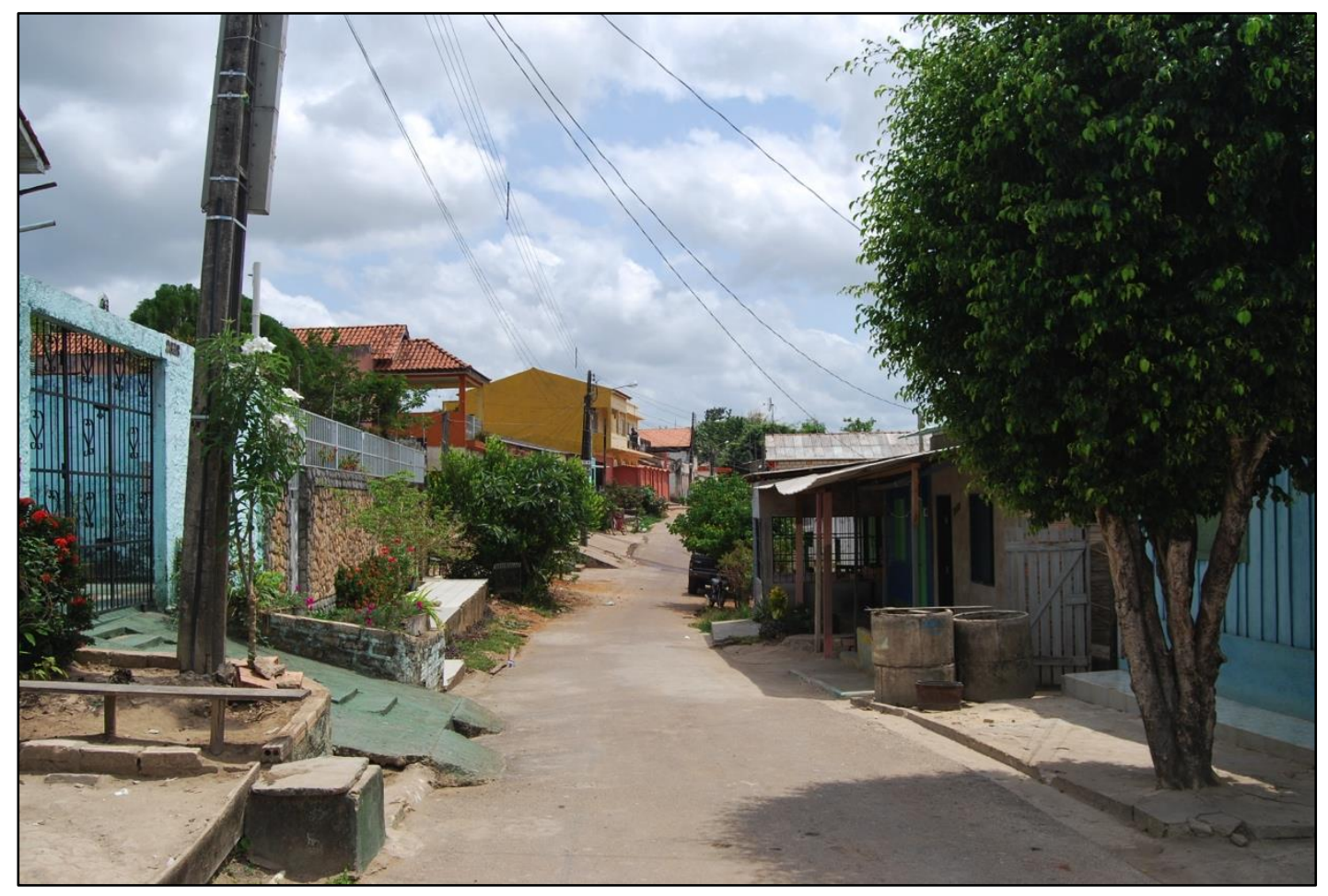

Figura 6 - Rua no bairro Muquiço (São Sebastião) - janeiro de 2012.

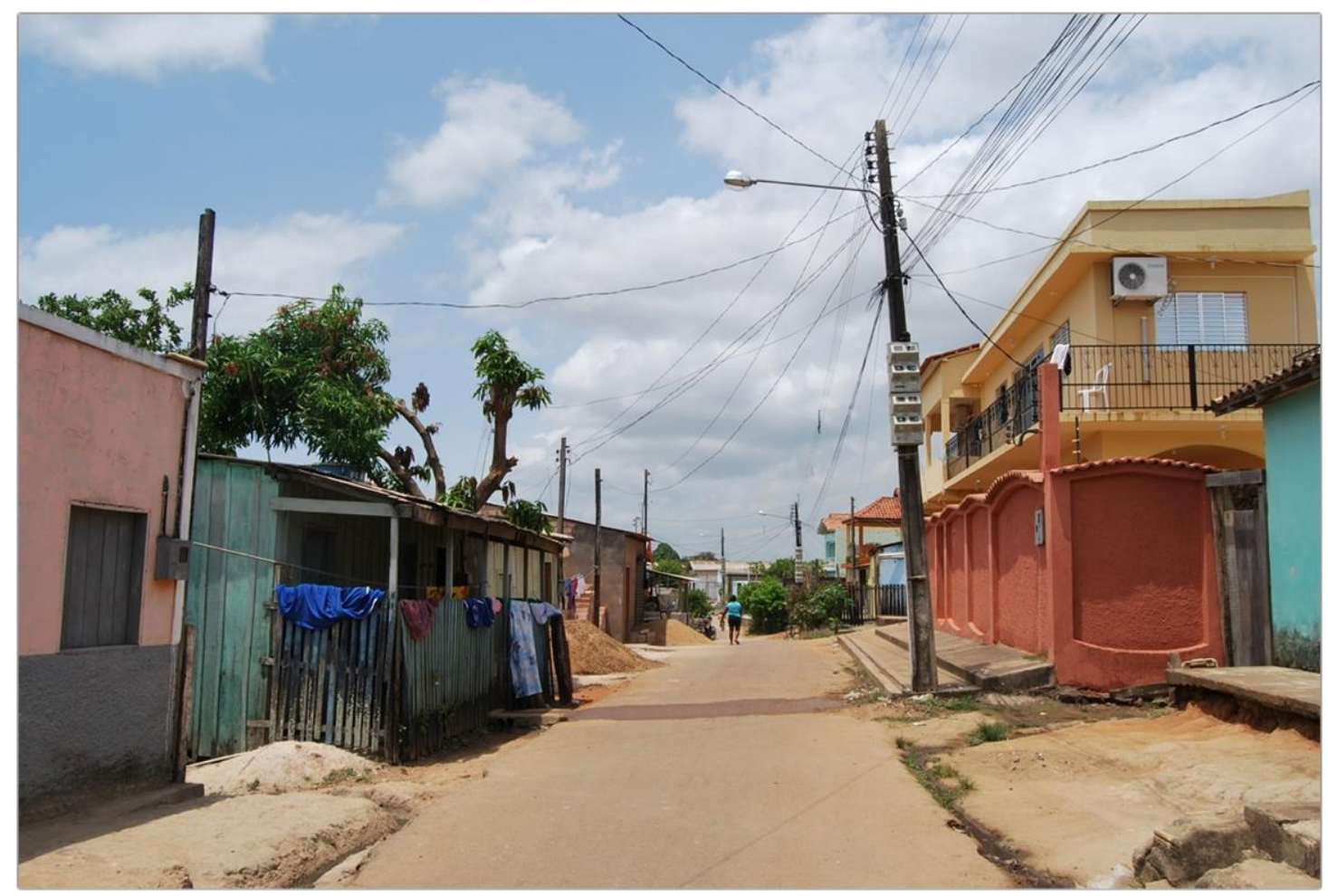

Figura 7 - Rua no bairro Muquiço (São Sebastião) - janeiro de 2012. 


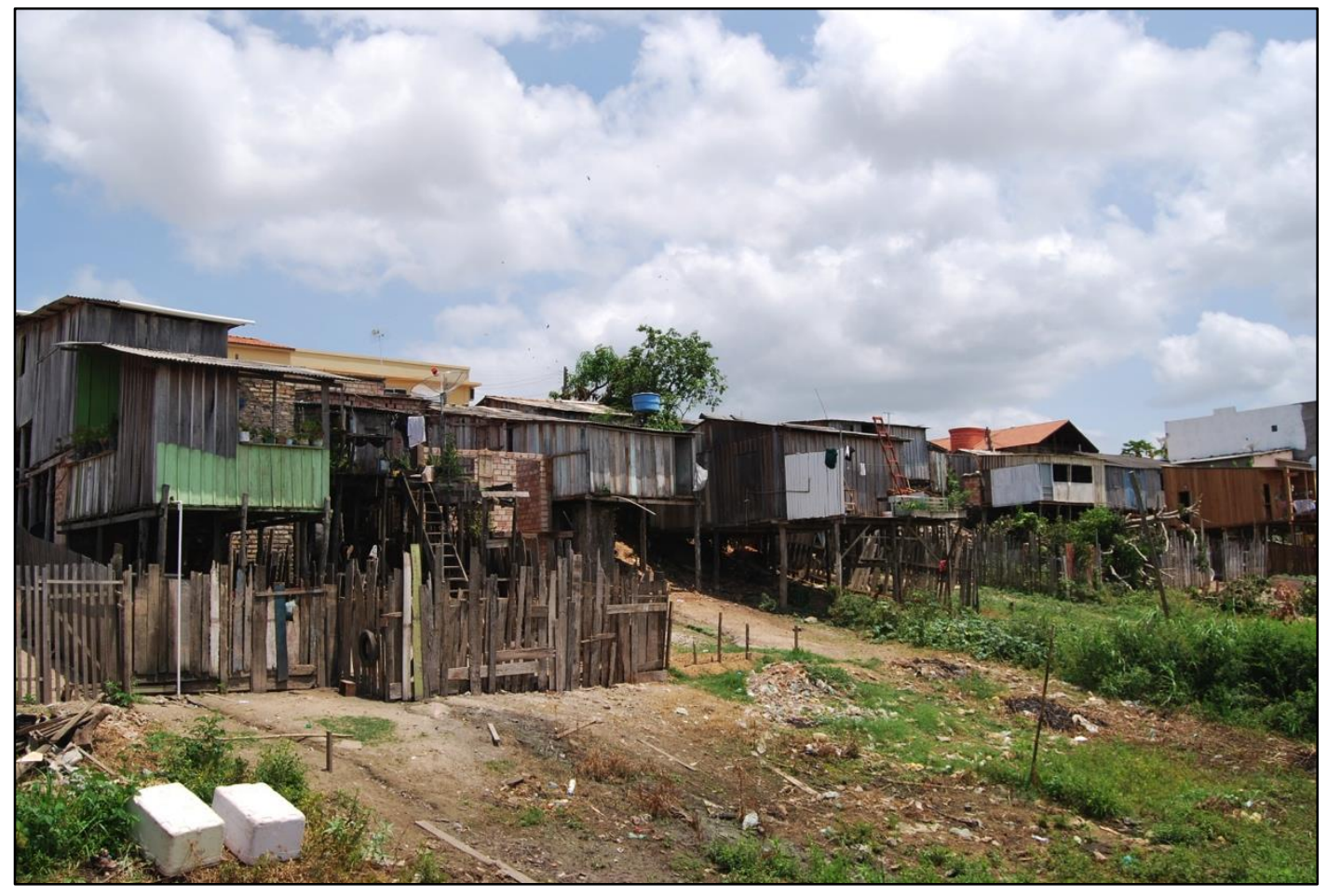

Figura 8 - Palafitas à beira do rio Xingu no bairro Muquiço (São Sebastião) - janeiro de 2012.

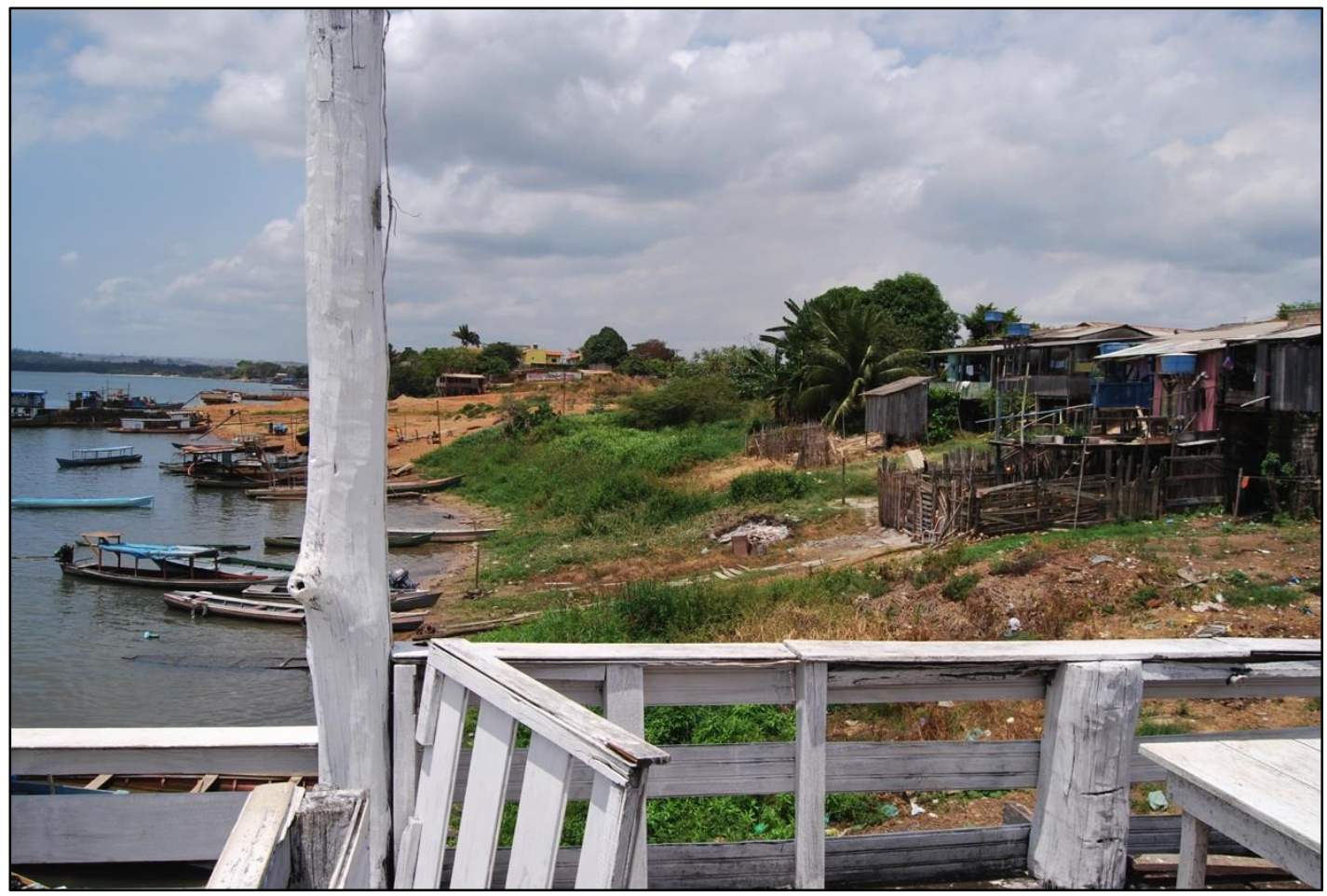

Figura 9 - Palafitas à beira do rio Xingu no bairro Muquiço (São Sebastião) - janeiro de 2012. 


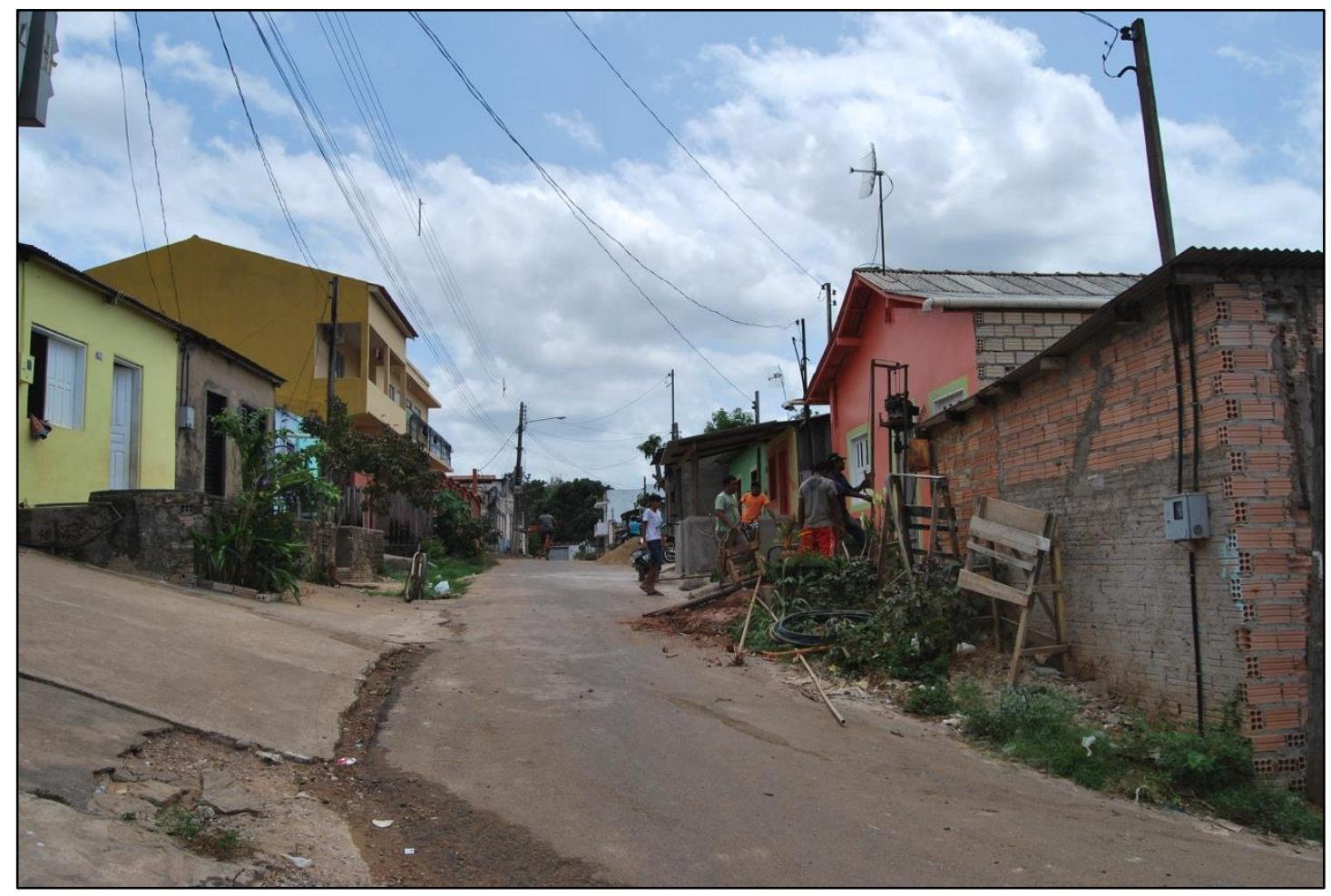

Figura 10 - Rua no bairro Muquiço (São Sebastião) - janeiro de 2012.

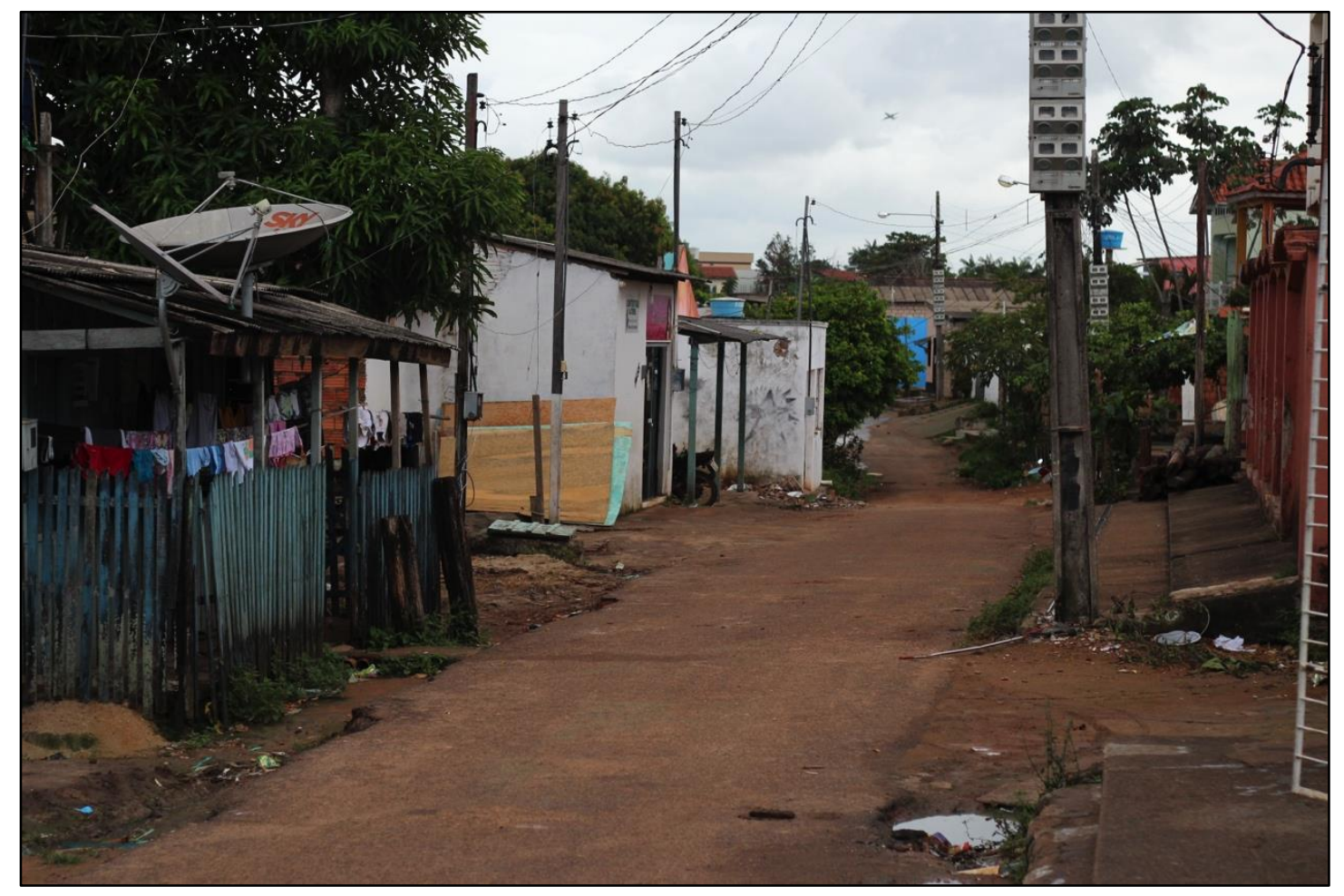

Figura 11 - Rua no bairro Muquiço (São Sebastião) - março de 2015. 


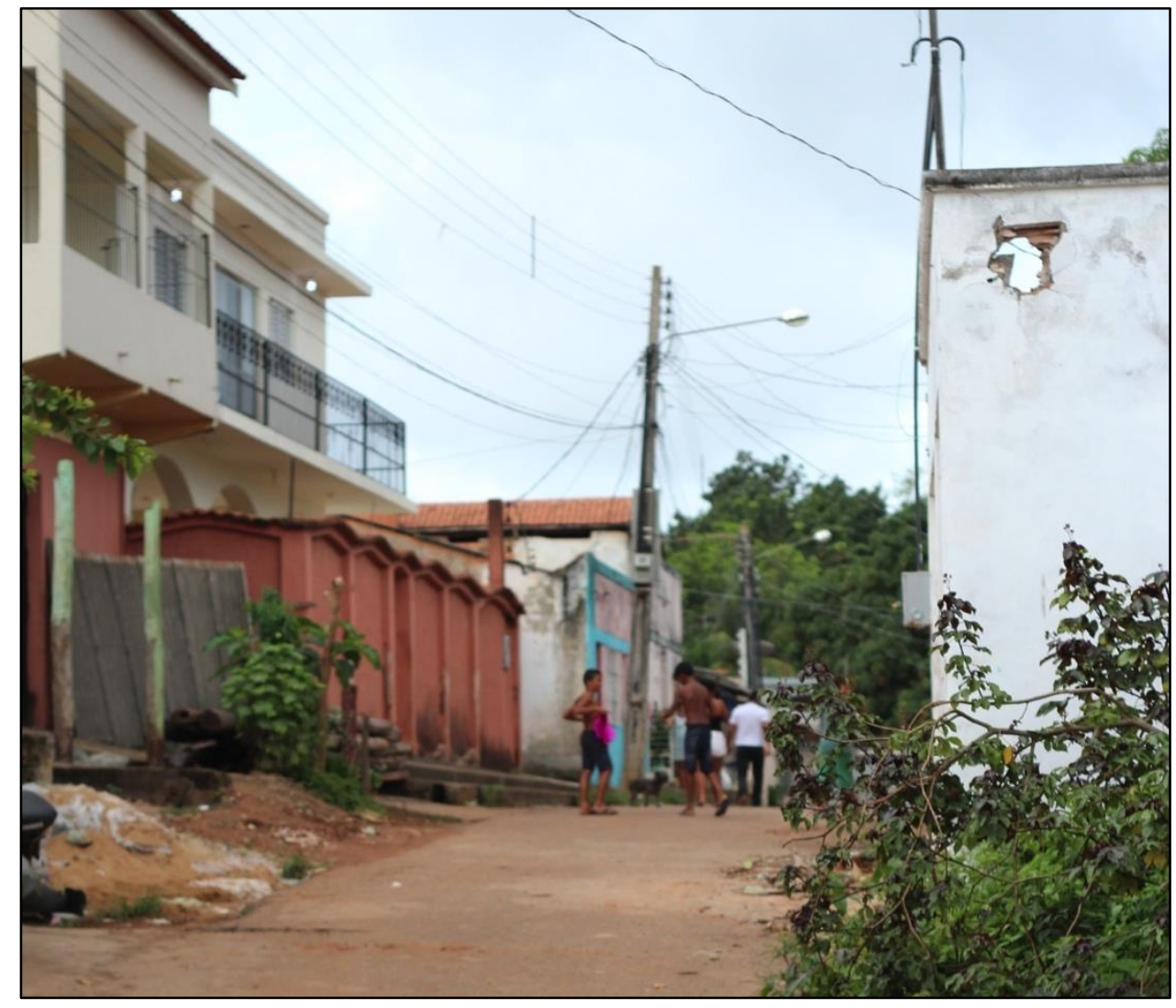

Figura 12 - Rua no bairro Muquiço (São Sebastião) - março de 2015.

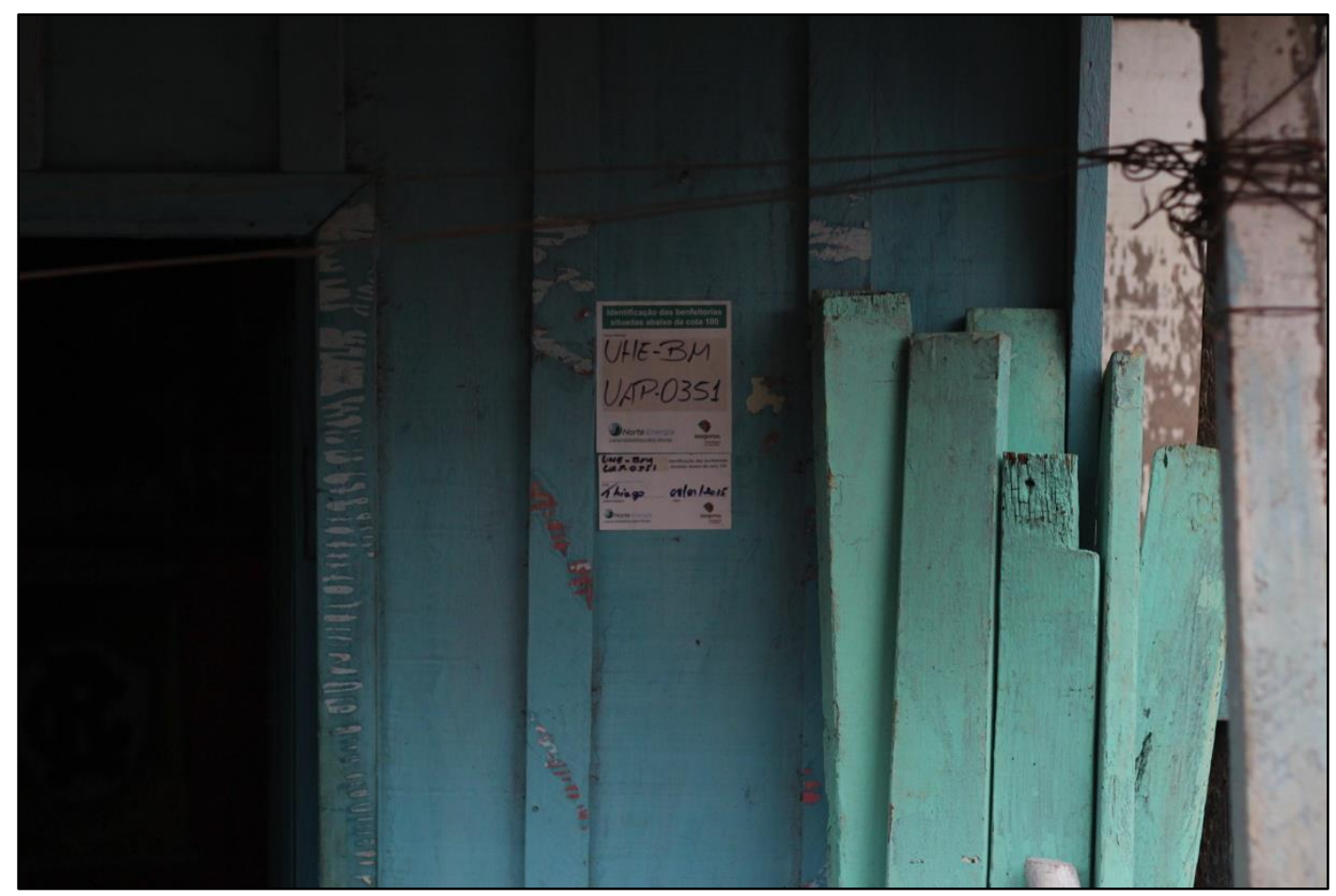

Figura 13 - Identificação de moradia afetada pela construção do reservatório de Belo Monte no bairro do Muquiço (São Sebastião) - março de 2015. 
Ao lado dos relatos históricos e memórias, aludidos no capítulo anterior, as imagens recentes do bairro dão pistas de como essa região sofreu e sofre com profundas transformações que atingem não apenas os modos gerais de ocupação do bairro, como infligem aos tradicionais moradores, principalmente indígenas Xipaya e Kuruaya mudanças para outras regiões da cidade. Em linhas gerais, até meados do século XX o bairro mantinha boa parte de sua mata ciliar, sendo caracterizado pelo afastamento do centro da cidade, com baixo número de moradores e dentre esses majoritariamente indígenas, onde era conhecido como "lugar onde mora o Taripu", para depois ser chamado de Muquiço ${ }^{46}$, já no processo de ocupação ligado a economia da borracha; após a construção da Rodovia Transamazônica recebe mais moradores já com a presença da cerâmica São Sebastião, passando a ser chamado por esse nome. Ao final do século XX, o bairro começa a se re-situar perante a cidade, aproximando-se do centro e despertando o interesse imobiliário, e durante a nova divisão dos bairros da cidade passa a fazer parte do bairro Esplanada do Xingu, sendo caracterizado como ainda podemos observar nas imagens apresentadas, antes na nova reestruturação urbana imposta pela construção da usina de Belo Monte.

Fazendo fronteira com o bairro São Sebastião, ao sul do centro de Altamira indo em direção ao Igarapé Panelas, encontra-se a região do bairro Jardim Independente II, ainda próximo a margem do Xingu e Jardim Independente I, que avança sobre o interior do continente, e Jardim Independente III, mais ao sul, já bem próximo do Igarapé Panelas, e que ainda tem baixa ocupação. Conhecido pela marcante presença indígena, esses bairros ainda são relembrados pelos antigos nomes Missão e Aldeinha, como eram referidos, como foi discutido no segundo capítulo. Semelhante ao que aconteceu no bairro São Sebastião, os referidos bairros também passaram por processo de especulação imobiliária recente, contudo principalmente em suas áreas próximas à margem do rio Xingu onde hoje pode-se observar desde residências de pessoas de alto poder aquisitivo, até restaurantes e hotéis.

\footnotetext{
${ }^{46}$ Ver Capítulo 2 - "Do Alto à Missão: histórias indígenas de Altamira"
} 


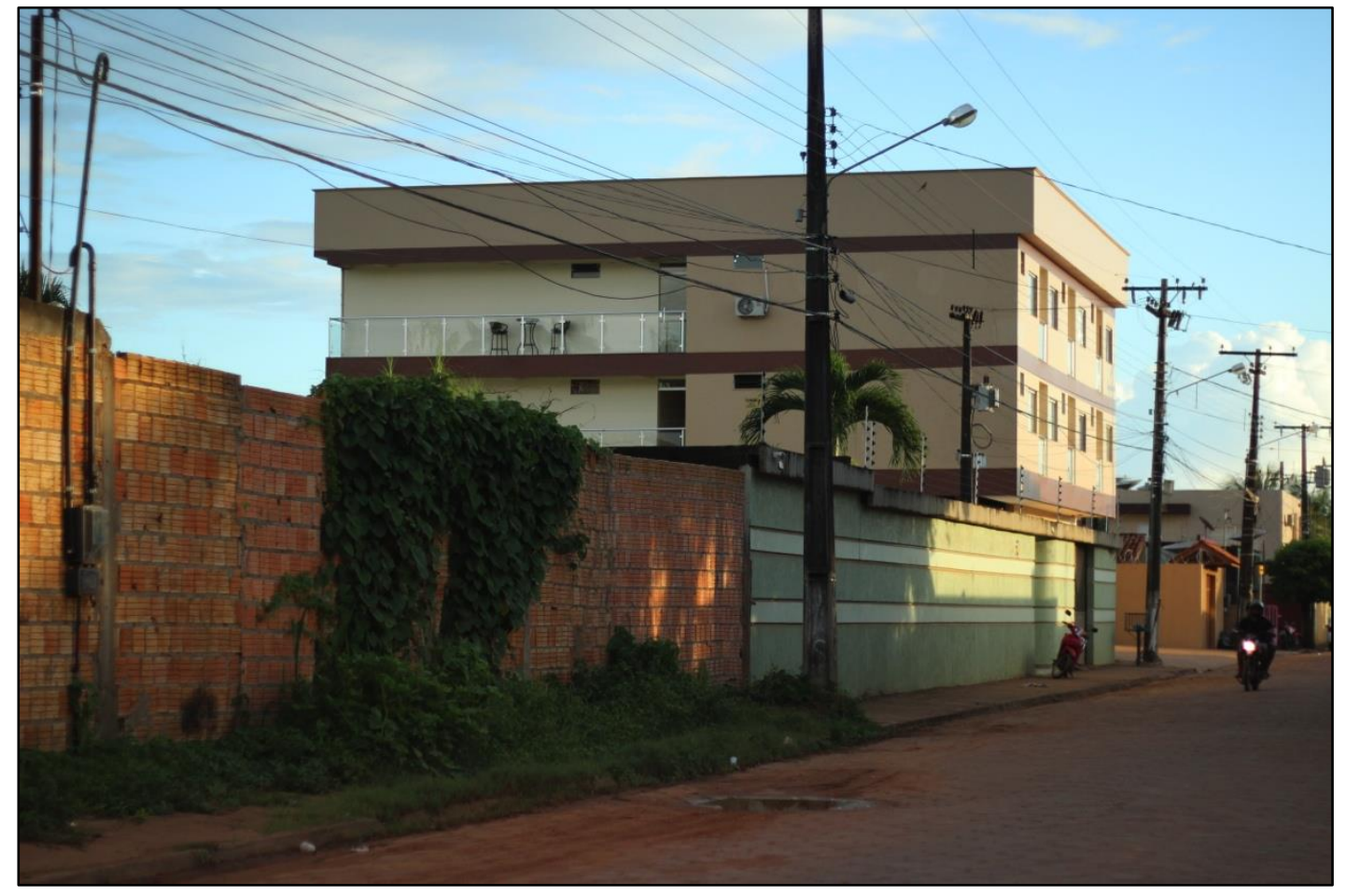

Figura 14 - Rua Cel. José Porfírio (via principal) no bairro Jardim Independente II - março de 2015.

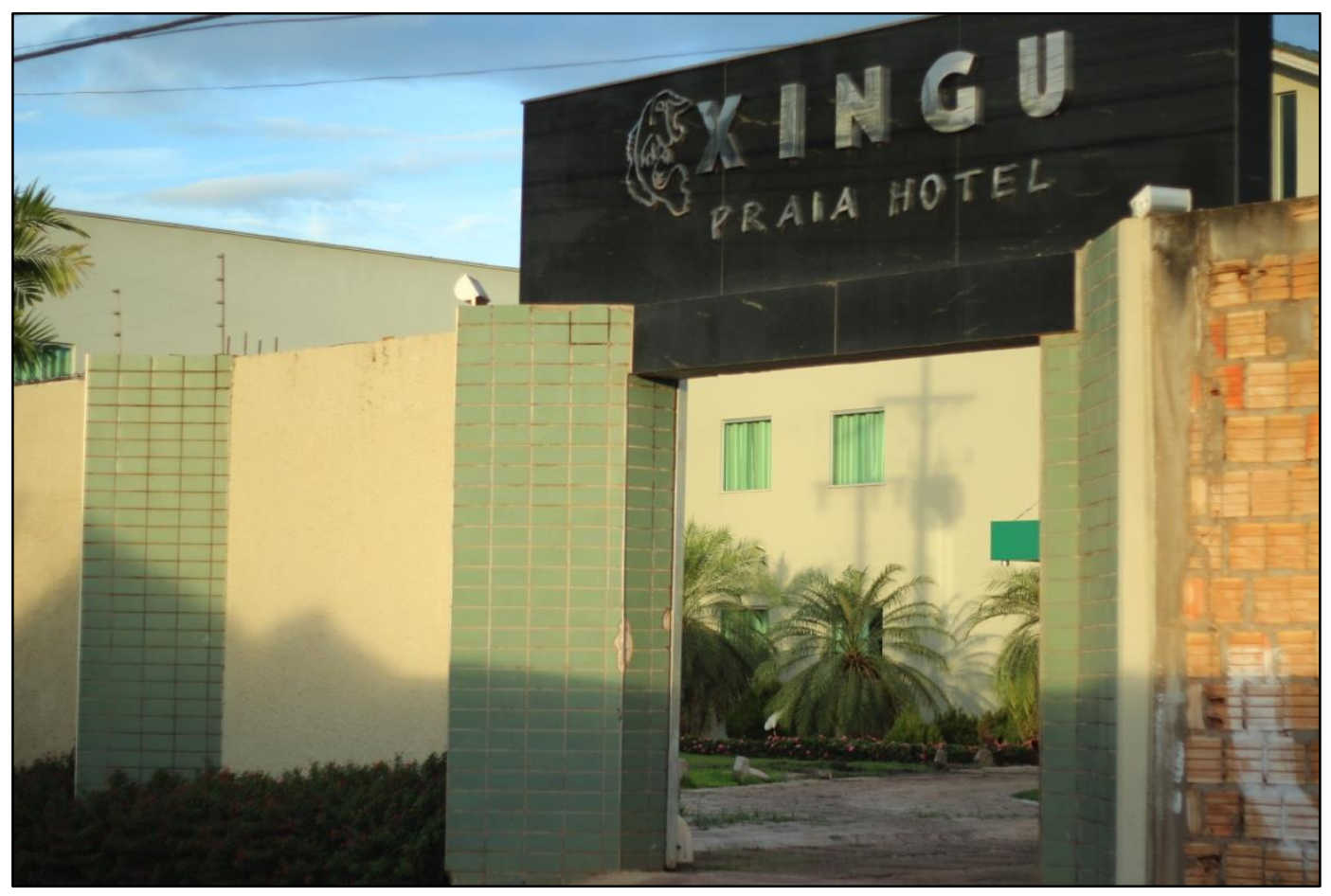

Figura 15 - Hotel na Rua Cel. José Porfírio (via principal) no bairro Jardim Independente II - março de 2015. 


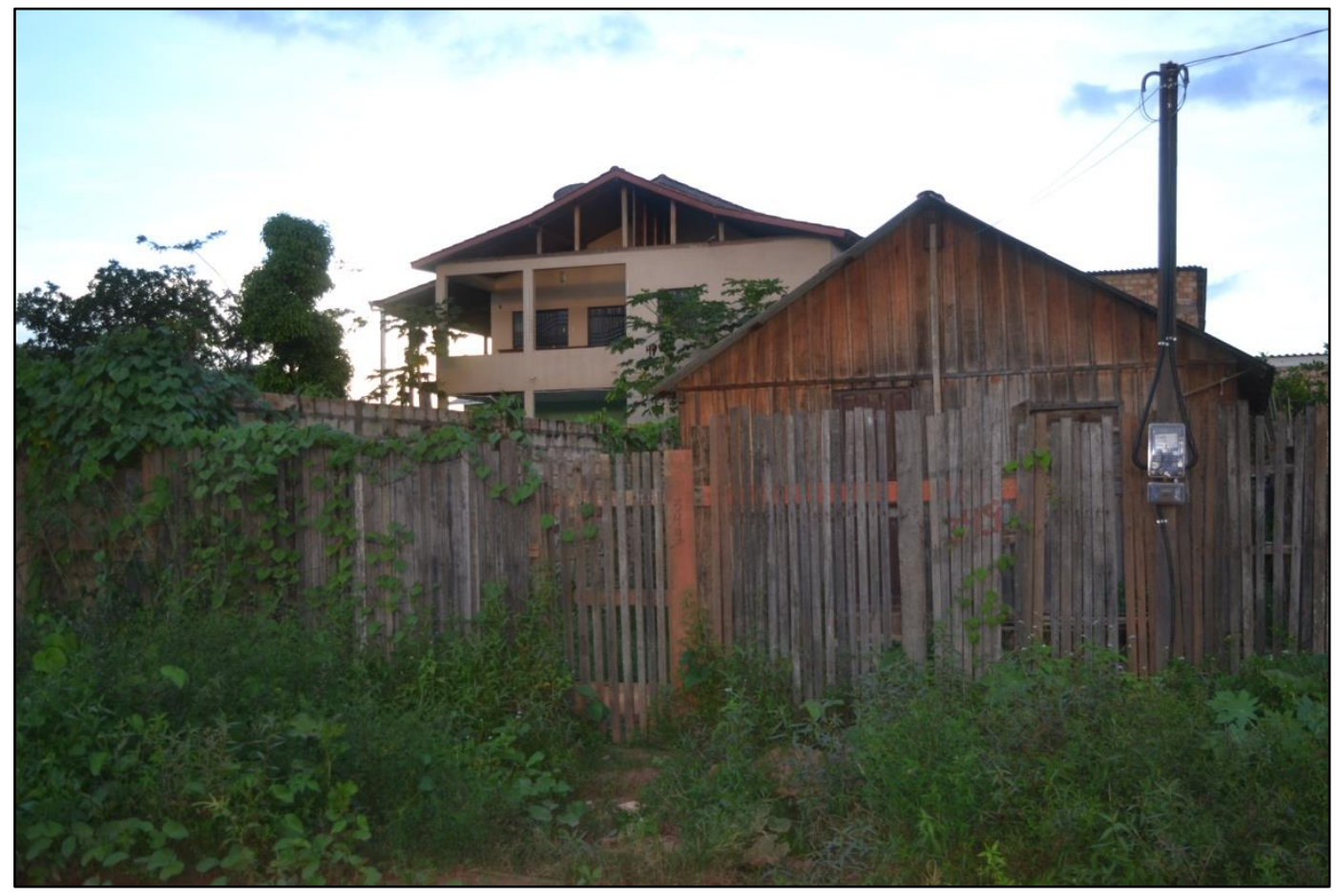

Figura 16 - Rua no bairro Jardim Independente II.

Esse processo remonta aos relatos e memórias históricas de seus antigos moradores, ao descreverem o momento em que muitos dos indígenas residentes desocuparam a região da beira do rio para instalação dos barracões de aviamento de seringueiros que posteriormente foram usados para apoio a atividade de caça do gato, até início dos anos de 1960, época em que o lugar passou a chamar de bairro das Onças. Contudo, com uma área expressivamente maior do que a do pequeno bairro de São Sebastião, o bairro atualmente avança sobre o continente, limitando seu crescimento ao sul pela existência de propriedades, como o Xingu Praia Clube, até encontrar o igarapé Panelas. Nessas regiões mantém-se o perfil de moradias de baixa renda, com muitas casas de madeira, sendo algumas de palafita. 


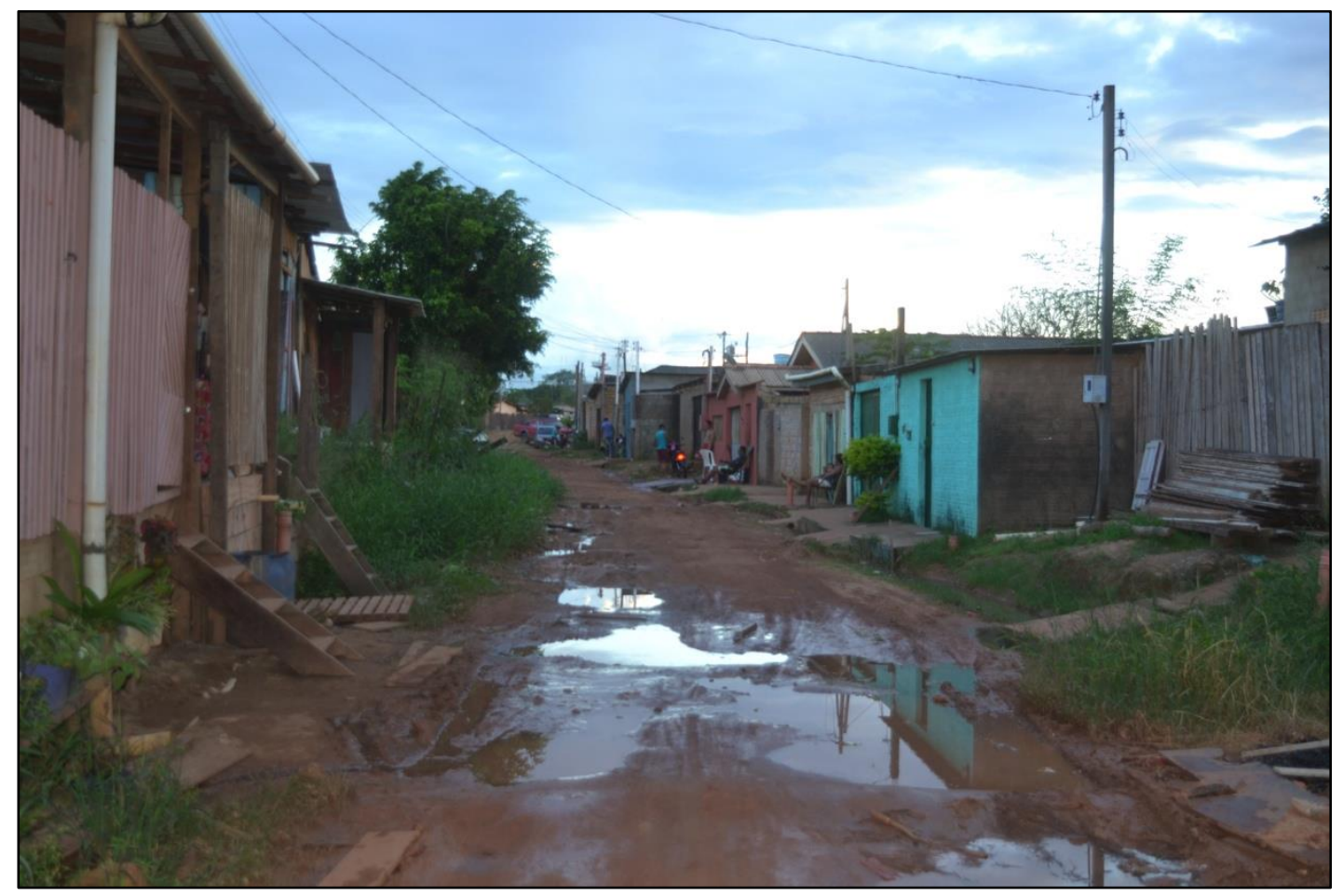

Figura 17 - Rua no bairro Jardim Independente II - março de 2015.

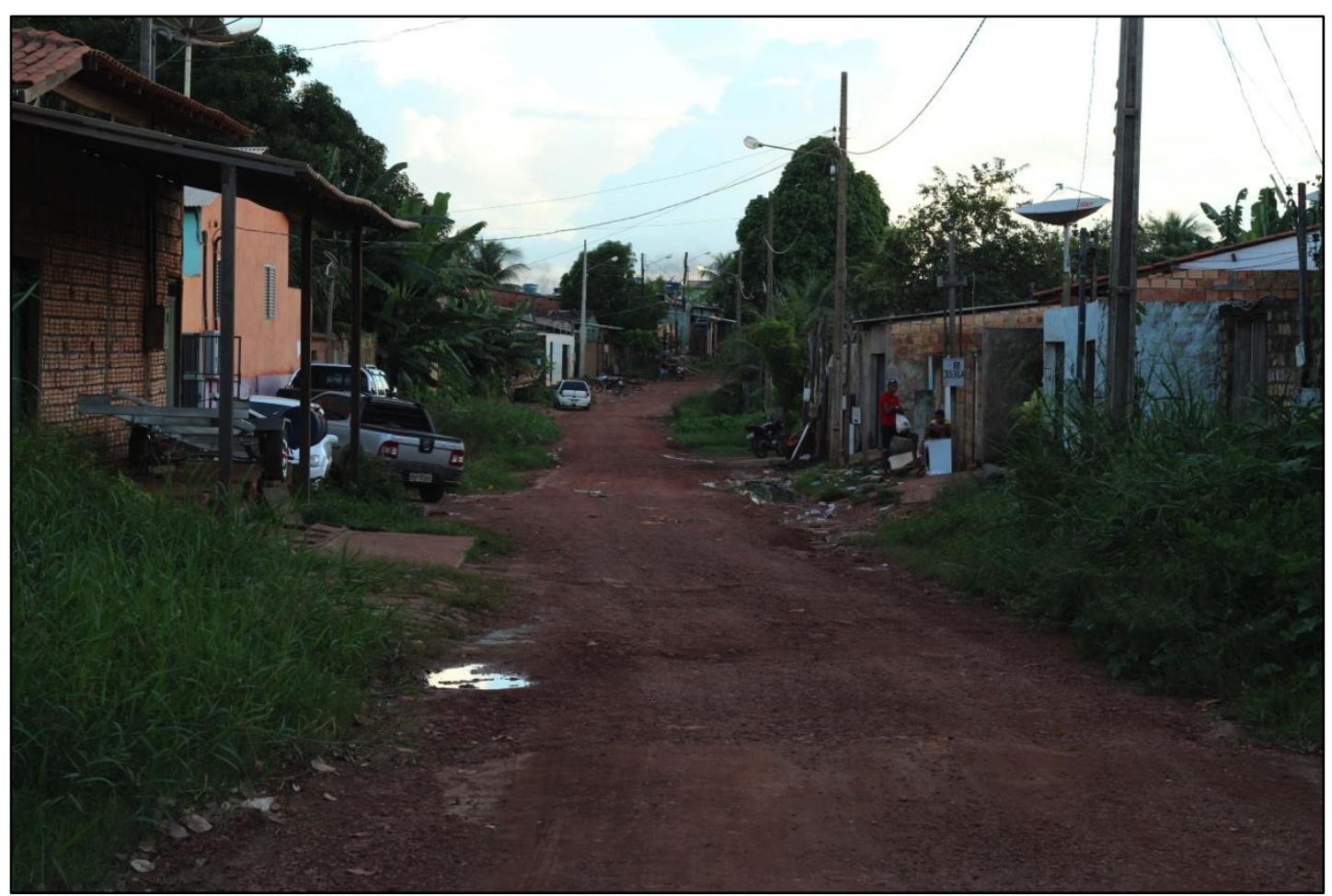

Figura 18 - Rua no bairro Jardim Independente II - março de 2015. 


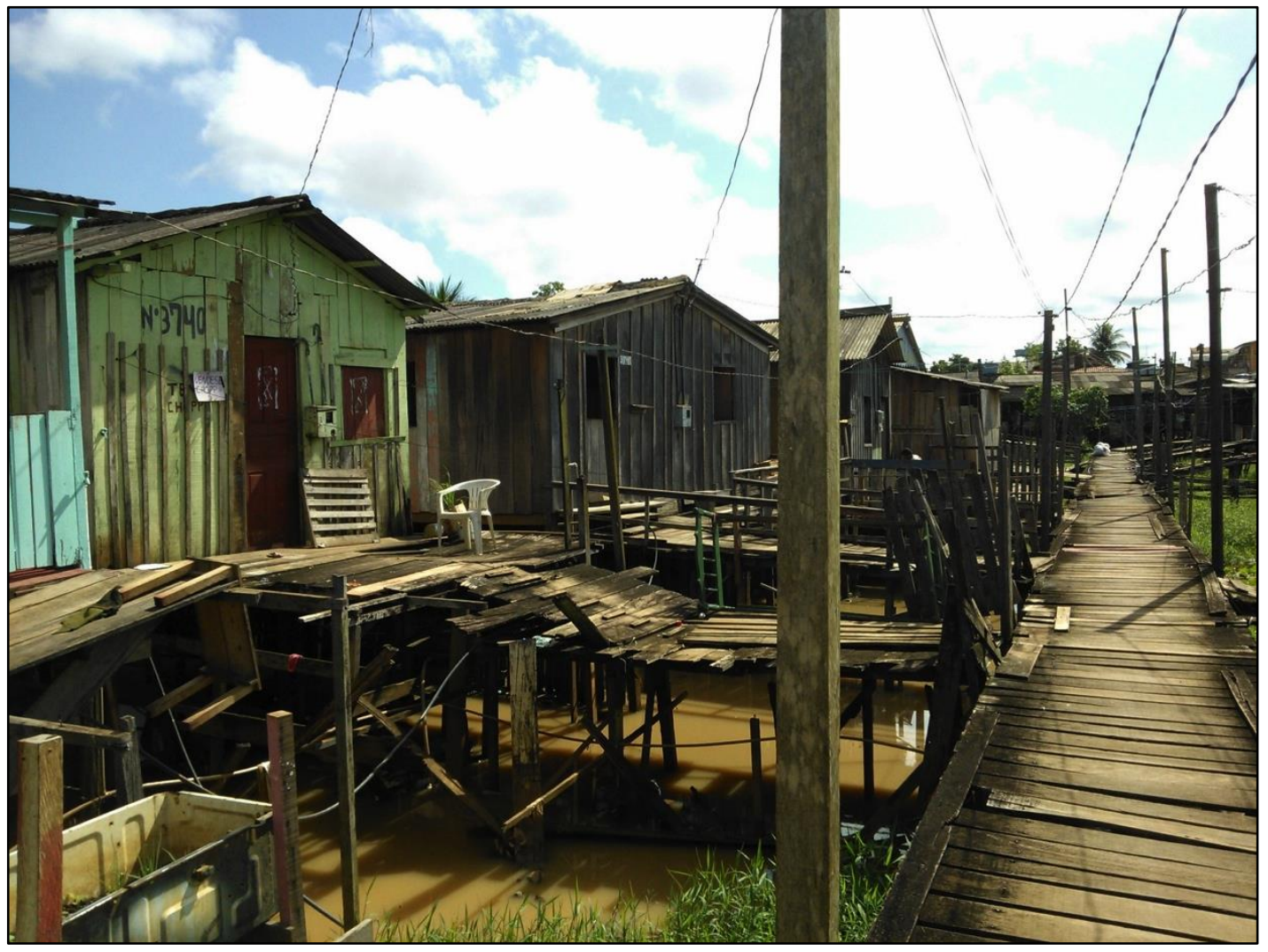

Figura 19 - Palafitas no bairro Jardim Independente II - maio de 2015.

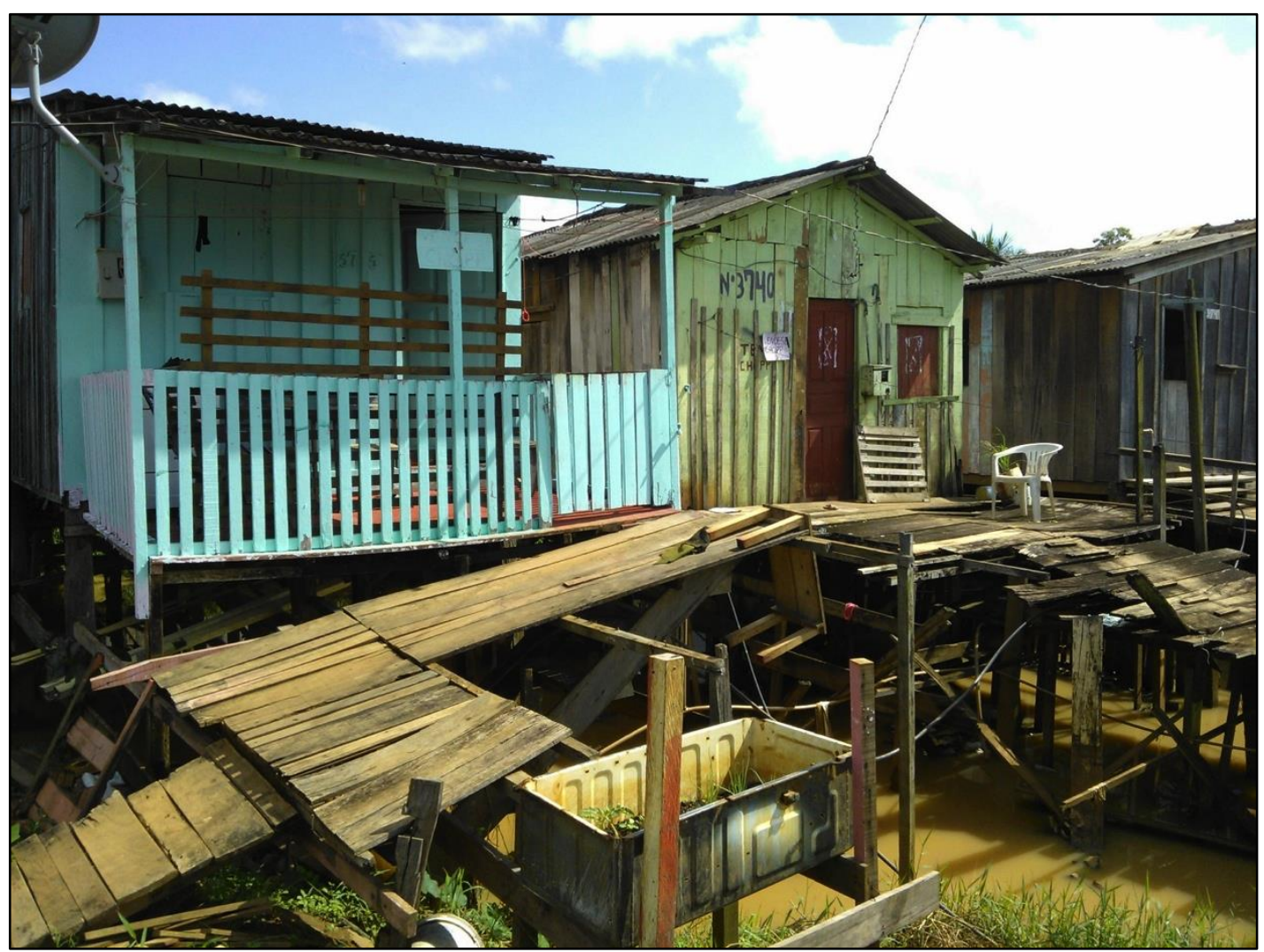

Figura 20 - Palafitas no bairro Jardim Independente II - maio de 2015. 


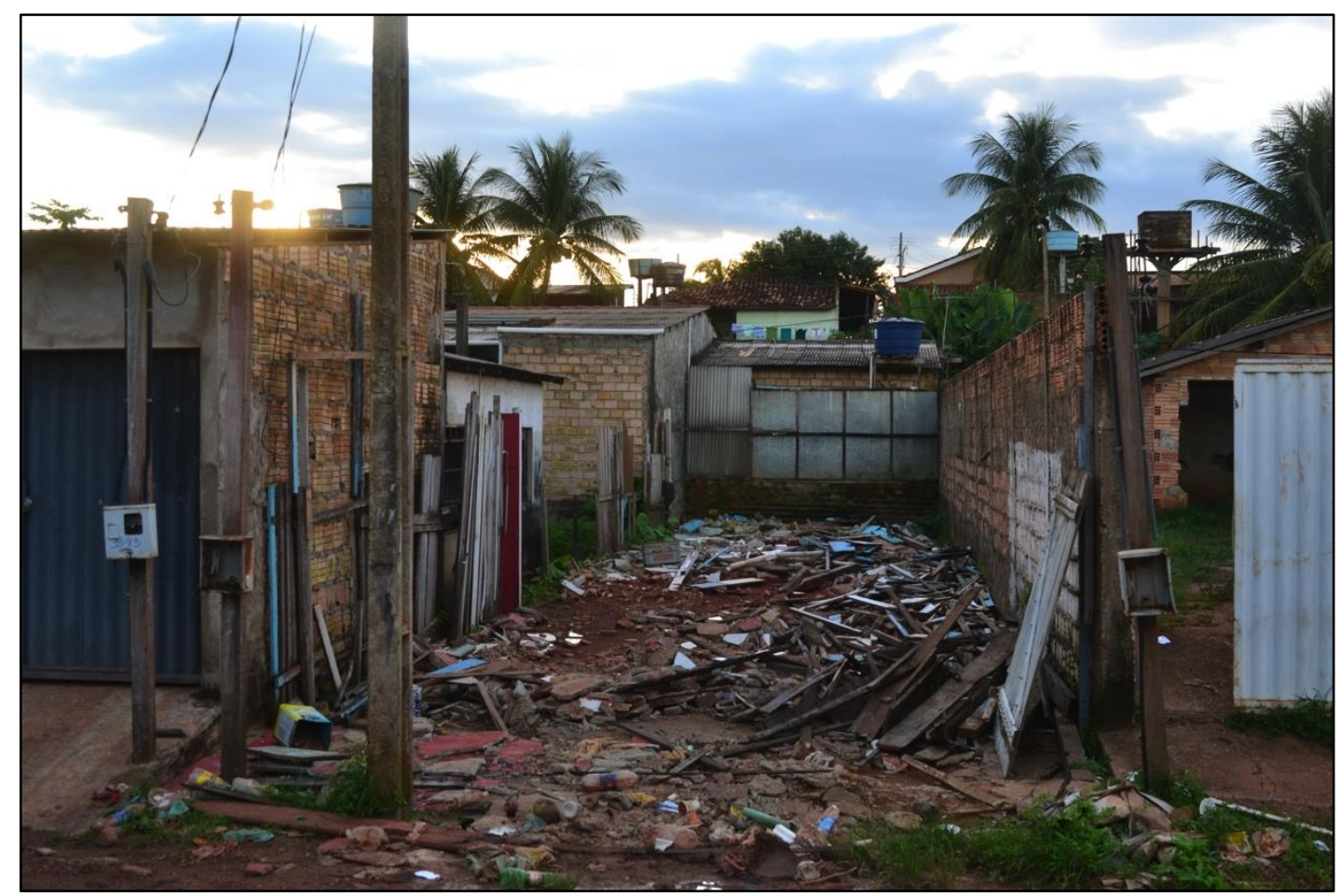

Figura 21 - Início das realocações de moradias por conta do reservatório de Belo Monte no bairro Jardim Independente II - março 2015.

Esse perfil de ocupação, característico da urbanização de algumas cidades brasileiras, onde coexistem numa mesma região moradores de classes sociais distintas, em Altamira, como em outras cidades amazônicas, agrega as diferenças étnicas da presença dos grupos indígenas. Formados por essas populações, principalmente pelos Xipaya e Kuruaya, esses bairros mantiveram-se durante um longo período do século XX como principais áreas onde residiam as famílias indígenas de Altamira. Mesmo durante as transformações trazidas pela construção da Rodovia Transamazônica, momento em que houve uma profunda transformação da região, com novas ondas migratórias, num processo que criou novos bairros na cidade e consolidou a mudança de muitas famílias indígenas para os bairros ao norte da cidade, como foi dito (Açaizal, Brasílias, Aparecida, entre outros), os bairros em questão mantiveram-se com uma expressiva população indígena. Na nova divisão dos bairros da cidade, passaram a chamar-se Jardim Independente I e II e assim também adquiriram outro status perante a cidade tornando-se também regiões então próximas ao centro. Atualmente, também aguardam os impactos trazidos pela necessidade de realocação da famílias que residem abaixo da Cota 100 do reservatório de Belo Monte. 
Tendo em vista esse panorama, compreende-se alguns dos fatores que impuseram a dispersão das famílias indígenas nessas localidades. Como foi discutido anteriormente, a presença de populações indígenas, de diversas origens étnicas, se dá na cidade como um todo, com destaque para determinados bairros conforme foi apresentado. Nas regiões eleitas pela presente pesquisa para se pensar experiências contemporâneas dos indígenas de Altamira, tem-se um quadro específico, mas que guardou e guarda relações fundamentais com dinâmicas de ocupação de toda região do médio rio Xingu. Patrício (2000) ressalta a configuração difusa da ocupação dos grupos indígenas de Altamira nos bairros São Sebastião (Muquiço) e Açaizal:

"Portanto, ao mesmo tempo em que os bairros têm como moradores os Xipaia
e os Curuaia, eles repartem o espaço com não-índios que não fazem parte da
família. Desta maneira, o território não se configura numa aldeia-reserva,
como ocorreu com os Terena nos municípios de Aquidauana e Campo Grande
- de maior caráter urbano - ou ainda Nioaque e Miranda, todos no Mato
Grosso do Sul (pesquisados por Cardoso de Oliveira, 1968:127). Mas,
assemelha-se. Conseguimos localizar as famílias na cidade de Altamira graças
as indicações que uns faziam dos outros, conforme mencionados no inicio
deste capitulo". (PATRICIO, p. 86, 2000).

A afirmação da autora traduz as dificuldades para pensar a situação dos indígenas que habitam as cidades, quando as próprias referências teóricas sobre situações semelhantes não conseguem dar conta das manifestações que se desdobram nesse contexto. O que subjaz aqui também são os esquemas mobilizados para se considerar de forma abrangente o problema da presença indígena nos meios urbanos: se não há um elemento que pode ser extrapolado dos citadinos não indígenas, a própria vizinhança diversificada, típica dos contextos urbanos pode tornar-se um entrave na compreensão dos fenômenos indígenas na cidade, ou seja, como Cardoso de Oliveira (1968) havia sugerido, para encontrar a "persistência da aldeia na cidade". Ao mesmo tempo sugere-se uma rede de comunicações, compreendida pelo universo urbano, que atua na construção e manutenção de relações que estruturam laços de pertencimento e afinidades entre os habitantes indígenas da cidade; são esses elos (quem sabe os "tribais" de Cardoso de Oliveira?) capazes de caracterizar a experiência desses grupos. Para Nunes (2010), a recusa da "lógica da terminologia" é uma implicação epistemológica necessária para que se possa pensar satisfatoriamente sobre as relações (sejam de habitação, passagem, ou vizinhança) dos indígenas com as cidades. Essa recusa nos previne de esquecer que estamos observando uma grande variedade fenômenos: 


\begin{abstract}
"O que essa diversidade nos mostra é que não há uma situação a que se possa referir como essa "situação de urbanidade" dos índios. As especificidades de cada caso implicam modos (e intensidades) de relação específicos com a cidade. Assim, ao pensar um caso de inserção indígena na cidade - e isso deve ser feito empiricamente -, há de se levar em conta sua sócio-cosmologia, e dentro desta "estrutura" geral, sua noção específica de territorialidade". (NUNES, p. 19, 2010)
\end{abstract}

Caracterizar as experiências indígenas na cidade de Altamira é, antes de tudo, acompanhar as especificidades de suas manifestações. Portanto, para a etnografia, foi importante aproveitar determinados recursos analíticos, a primeira vista incapazes de observar as sutilezas dos fenômenos que são objetos das pesquisas, mas que ao serem considerados em interface com elementos críticos das experiências entre indígenas e pesquisador, são capazes de dialogar com as nuances do universo da pesquisa. Esse espaço foi identificado, num primeiro momento, com o perímetro da cidade de Altamira, mas é antes de tudo um ambiente definido por meio dos processos específicos que o comportam, como defende Nunes: "ao considerarmos um caso específico de inserção indígena no ambiente urbano, devemos fazê-lo tendo em conta o regime de subjetivação e o modelo de socialidade específicos do grupo em questão" (NUNES, p. 23, 2010).

Avançando na análise dos indicadores ocupacionais dos moradores indígenas de Altamira, será possível observar novamente a referências à situação de equidade entre os habitantes indígenas e não indígenas dos bairros de Altamira, como a encontrada para as condições de moradia urbana da população indígena da cidade. Ao mesmo tempo, tais evidências, quando dispostas nos contextos etnográficos, também possibilitam o entendimento mais próximo dos modos e concepções que os interlocutores manejam em seu dia-a-dia, dando subsídios às problematizações pretendidas pela presente pesquisa.

\title{
3.2.1 Ocupações: fragmentos sobre vivências indígenas em Altamira
}

Em correlação com a condição habitacional dos indígenas moradores de Altamira, a situação de trabalho dos mesmos é precária e marcada pela informalidade. Observando os dados apresentados pelo relatório do Projeto de Cadastro Socioeconômico das Famílias Indígenas moradoras da cidade de Altamira e da Volta Grande do Xingu (2012), tem-se a 
seguinte situação da renda familiar dos indígenas de Altamira localizados nas áreas do reservatório de Belo Monte:

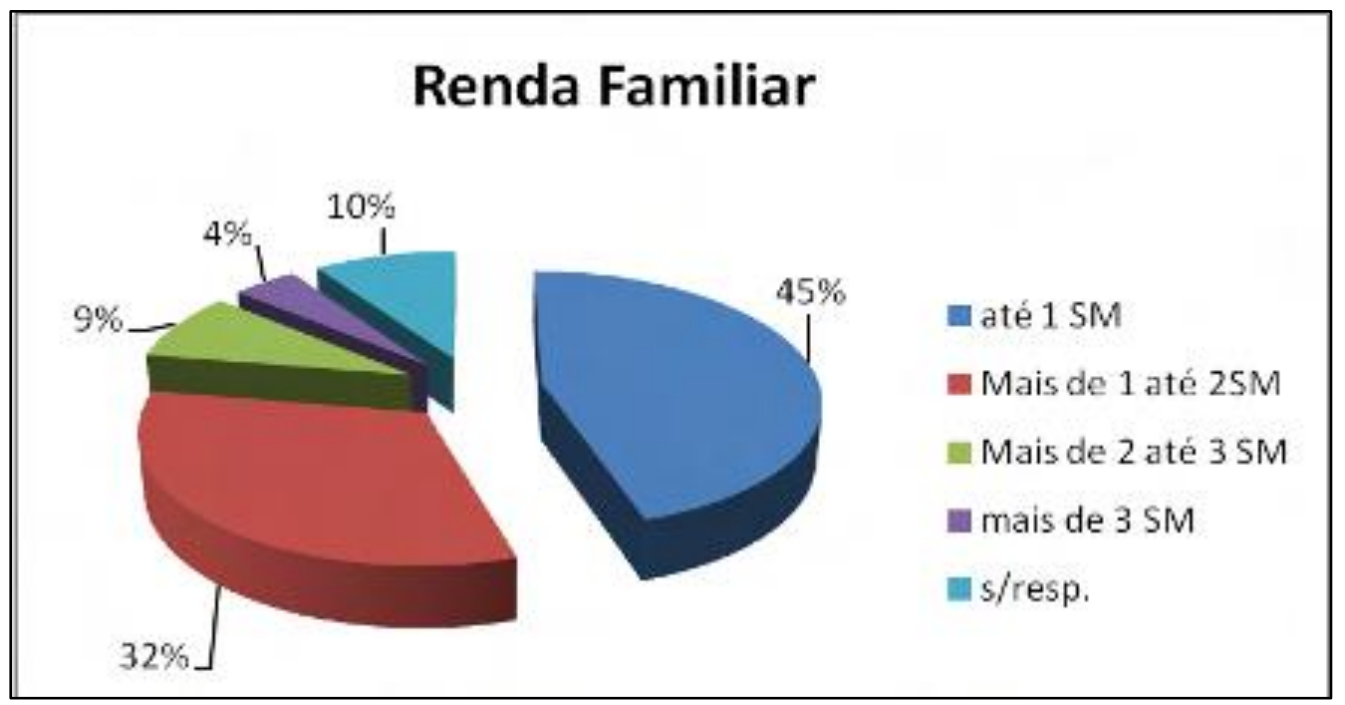

Figura 22 - Renda familiar. Fonte: Relatório final de Cadastro das Famílias Indígenas (NORTE ENERGIA, 2011).

Com $45 \%$ dos indígenas recenseados com uma renda familiar de até um salário mínimo, temos mais um indicador que evidencia a situação vulnerável dos habitantes indígenas da cidade. Olhando para os indicadores de ocupação dos chefes de família ${ }^{47}$ cadastrados pelo projeto tem-se a seguinte situação:

${ }^{47}$ É importante indicar que o cadastro priorizou a entrevista ao chefe de família, ou cônjuge indígena, e na ausência desses o chefe ou cônjuge não indígena. Sobre essa situação o relatório alerta: “(...) muitas vezes fomos questionados sobre a "incoerência" do cadastramento de propriedades que possuem como proprietários e chefes homens não indígenas casados com mulheres indígenas. Assim, cabe ficar esclarecido que este Projeto considerou como famílias indígenas aqueles grupos familiares compostos por um ou mais cônjuge indígena, o qual se autodeclara indígena e a comunidade, indígena ou não, o considera como tal" (Norte Energia, 2011), demonstrando as dificuldades do próprio cadastramento em justificar a situação específica dos indígenas moradores da cidade. Sobre a definição de chefe de família para o cadastro, esta não consta no relatório. 


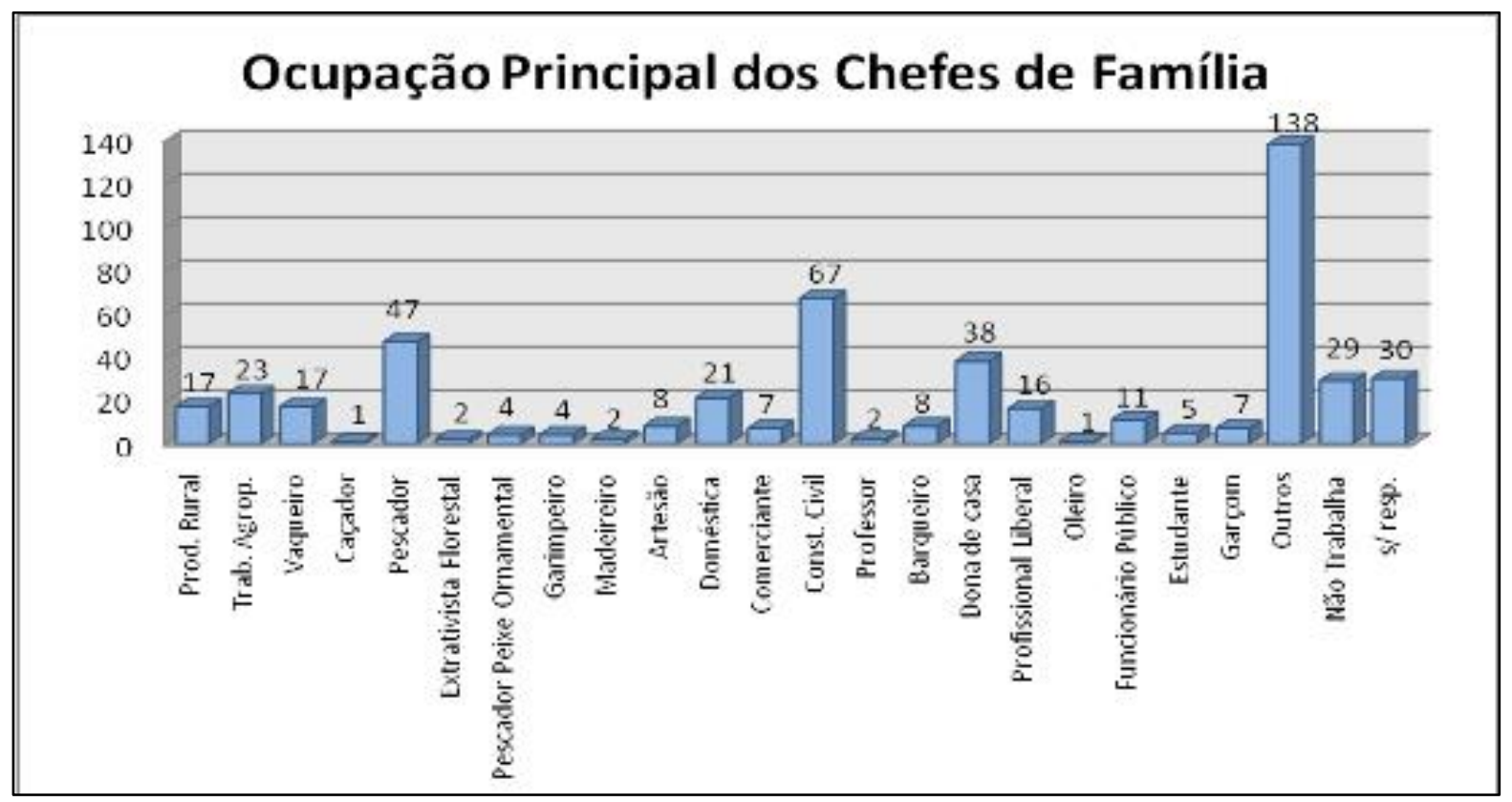

Figura 23 - Ocupação dos chefes de família. Fonte: Relatório final de Cadastro das Famílias Indígenas (NORTE ENERGIA, 2011).

O número que salta aos olhos, no que diz respeito a ocupação principal dos chefes de famílias indígenas, corresponde à alternativa "outros" englobando uma série de atividades diferentes, segundo o relatório, que incluem desde trabalhos com vínculo empregatício até aqueles excluídos de qualquer garantia trabalhista (lavadeira, mecânico, pintor, moto-táxi, babá, cortes em frigorífico, marceneiro, jardineiro, serviços gerais, vendedor, açougueiro, estivador, fábrica de bloquetes, aux. topógrafo, mergulhador, carpinteiro, pesquisador e vidraceiro) a grande maioria das atividades, por sua vez, ligadas ao contexto urbano dos moradores. Essa parcela corresponde à pouco mais de $27 \%$ do total cadastrado. Destacam-se também as ocupações da área de construção civil, representando 13,3\% do total essas atividades estão vinculadas à atual conjuntura de Altamira, com a construção da usina de Belo Monte $^{48}$. Cumpre indicar que essa absorção dos indígenas da cidade no bojo dos postos de trabalho criados pela presença de Belo Monte não significa a alocação direta na construção da obra, muitas vezes esses postos são criados de forma indireta, como por exemplo pelo aquecimento do mercado imobiliário. Embora não se tenha encontrado indicadores numéricos

\footnotetext{
${ }^{48}$ Ao compararmos esses dados com os do EIA/RIMA - Componente Indígena citadino de Altamira e ribeirinho da Volta Grande do Xingu (Eletronorte, 2009) expõem-se os efeitos da presença de Belo Monte. Dentre as ocupações principais dos 340 chefes de famílias indígenas entrevistados tem-se a seguinte proporção das mais importantes: $5,9 \%$ são agricultores; $12,6 \%$ são aposentados; $4,1 \%$ são domésticas; $10,3 \%$ são pedreiros; $9,4 \%$ são pescadores; e 7,9\% atuam em serviços gerais.
} 
precisos que indiquem a absorção de indígenas no mercado de trabalho de Altamira durante Belo Monte, no decurso dos períodos de campo realizados para a pesquisa foi possível observar a recorrente situação em que pelo menos um membro da família estava empregado diretamente na construção da obra, ou em empresas terceirizadas que efetuam serviços para obra, sendo tanto homens ou mulheres geralmente jovens ${ }^{49}$.

Seguindo com a análise dos dados ocupacionais, a expressividade da alocação em atividades tipicamente femininas, como domésticas, representando $4,2 \%$ da renda principal dos chefes de família, e a indicação da ocupação como donas de casas, representando 7,5\% do total, denotam a importância das mulheres para a reprodução de muitas famílias indígenas da cidade $^{50}$.

Muitas das principais ocupações que aparecem nos dados apresentados referem-se às atividades que se desenvolvem nas áreas rurais e rios da região. Situação a princípio incongruente com a vida na cidade dessas populações indígenas, revela as contradições dessas experiências que expressam a necessidade de refletir sobre as convenções que classificam os limites entre urbano e rural nesses contextos. Assim tem-se um processo tensionado pela presença cada vez mais ampla das novos atividades de trabalho, típicas do universo urbano (construção civil, funcionário público, garçom, mecânico, pintor, moto-táxi, estivador, entre outros), ao lado de ocupações que são relacionadas a vida rural (trabalhador agropecuário, vaqueiro, produtor rural, pescador, caçador, extrativista, entre outros). Se levarmos em conta apenas as ocupações relacionadas ao trabalho no campo, ou atividades de agropecuária e extrativismo, tem-se um montante de $11,7 \%$ da população indígena cadastrada atuando nessas áreas. Apesar dos trabalhos rurais não serem caracterizados pelo cadastramento, alguns indicativos de sua constituição podem ser observados se atentamos a sua dupla condição, como produtor particular ou trabalhador remunerado. Compreende-se aqui a necessidade do deslocamento das áreas urbanas para os lotes e fazendas nas quais esses trabalhos são desenvolvidos, produzindo relações que se estruturam por esse movimento. A participação da

\footnotetext{
${ }^{49}$ As implicações econômicas de Belo Monte, principalmente sua interferência sobre a mão-de-obra local, que inclui os moradores indígenas da cidade, é uma questão fundamental das transformações trazidas por Belo Monte. Contudo, a etnografia não acompanhou esses efeitos a fundo, se limitando a problematizar sobre os dados numéricos disponíveis. A discussão das implicações de Belo Monte sobre a política indigenista e o movimento indígena citadino será feita no Capítulo 4 "A política indígena na cidade de Altamira: desafios antes e durante Belo Monte".

50 A indicação do sexo dos chefes de família é uma informação bastante importante para compreender as dinâmicas dessas famílias indígenas da cidade, contudo não é discriminada no dados presentes no relatório. Alguns aspectos das relações de gênero nas famílias indígenas da cidade serão abordados mais à frente.
} 
população indígena na vocação agrícola dessa região, seja aquela estruturada pela venda do excedente ou pela força de trabalho, remonta ao momento em que se produziu o movimento de ocupação amazônica baseado na constituição das propriedades rurais. Recuperando o período de construção da Rodovia Transamazônica, com seus travessões, se forma a figura do colono, o migrante nordestino e principalmente o sulista que irão povoar as novas cidades formadas ao longo da rodovia. Inserida também nesse contexto, a cidade de Altamira, já com sua antiga ocupação que ia da missão religiosa com exploração da salsaparrilha até a economia da borracha, se vê num novo período de expansão onde as populações tradicionais da região, paraenses de origem indígena e nordestina, também são mobilizadas nas novas frentes de trabalho. Assim aparecem os novos relatos de conflito com indígenas "brabos" quando da abertura da rodovia (principalmente os Arara das atuais TI Arara e Cachoeira Seca), bem como delineiam-se os lugares em que as populações indígenas, já há tempo contatadas e vivendo na cidade ou na proximidade com os não indígenas, irão ocupar nesse novo processo. Coincidindo com o consolidado final da exploração da borracha e com a migração maciça para cidade dos grupos indígenas que ocuparam um lugar específico nesse processo (principalmente Xipaya, Kuruaya e também os Juruna vindos da Volta Grande do Xingu), a chegada da fronteira agrícola também relegou um papel próprio para esses grupos nesse processo. Assim podemos observar a importância das ocupações ligadas à atividade rural para as populações indígenas atingidas pelo reservatório de Belo Monte, ao lado dos indicadores sobre propriedades rurais apresentados pelo EIA/RIMA - Componente indígena citadino de Altamira e ribeirinho da Volta grande do Xingu (2009), que revelam que 22\% dos entrevistados indígenas da cidade possuem lotes, principalmente nas regiões da Volta Grande do Xingu e ao longo rio Xingu até a confluência com o rio Iriri. Durante as incursões ao campo, percebeu-se o costume entre os interlocutores de permanecer nos lotes rurais familiares durante os finais de semana ou por períodos mais longos para depois voltarem para cidade, onde continuam mantendo a moradia. Muitos passaram a usufruir desses lotes à beira do rio como forma de lazer, mas ainda persiste a função da terra para a produção agrícola que complementa a alimentação diária, com itens como farinha, feijão, arroz, entre outros, além de pequenas produções para venda, que consistem atualmente nessa região na cultura de cacau e criação de gado. O trecho do relato de José Mineiro da Silva, mais conhecido como Caneco Kayapó, mas nascido Moikrãn e atualmente morador do bairro São Sebastião (Muquiço), contém episódios de sua trajetória pessoal, e da família que formou com Maria Kuruaya, que dão mostra dos diversos e fatores e significados que correspondem as muitas 
experiências indígenas na cidade, falando sobre a importância das atividades rurais na reprodução das famílias:

“Essa roça está dentro do igarapé das Lajes, longe daqui. Daqui até lá são sete, oito horas de viagem, é longe. Em direção a São Felix (do Xingu)... É longe, nós temos que entrar cinco quilômetros mata adentro, a pé ainda, não tem estrada. Essa terra, eu pesquei nove anos daqui (Altamira), aí fui pro Iriri; não me dei lá mais a família, voltamos pro Passaí. Lá pra cima, pra onde eu fui, pro desvio, eu passei só um ano. Aí voltei pro Passaí; aí do Passaí eu já vim-me embora de vez. No Passaí eu topei com conhecido meu, o Justino - nós somos até compadres -, ele disse: 'Rapaz, tu vai embora?' eu digo: 'Vou', 'Rapaz, aqui que tem terra que você pode abrir uma roça aí..' Aí eu abri uma roça lá. Eu criei esses meus meninos tudinho lá. Passei vinte anos lá, nessa roça, nessa terra. Comecei aqui, terminei lá de criar eles todos. Tudo estão criados, eram dez bocas pra comer. Eu pescava e botava roça. Eu tenho uma carteira aí, que eu tenho trinta e seis anos de pesca. Primeira colônia que foi aberta aqui, negócio de colônia da pesca, eu tenho carteira dela. Esse peixe que pegava lá, eu vendia pro meu compadre Justino aqui, pra comprar o rancho lá. Eu vendia lá, de lá ele trazia pra cá né. Desse tempo já tinha gelo, ele trazia o peixe...”.

Essa composição, entre a agricultura e a pescaria é um modo de sobrevivência bastante difundido e ainda vital entre a população pobre de Altamira, de todas as etnias indígenas que habitam a cidade, e também dos muitos não indígenas agricultores e pescadores. É possível verificar com o relato de Caneco que a agricultura, como forma de geração de renda, passou a ocupar um lugar mais tardiamente para essas famílias, já após o declínio da atividade de extração de látex e com a consolidação da rodovia Transamazônica como vetor agropecuário para a região. Após viver da pesca, Caneco inclui a agricultura como sustento, passando a viver no lote que mais tarde sofreria desintrusão pela FUNAI para atualização e consolidação dos limites da Terra Indígena Asuriní do Koatinemo, previstos desde o ano de 1979, mas que foram executadas apenas em 2012, período a que se refere Caneco. Embora esse episódio fale do drama particular da família de Caneco Kayapó e Maria Kuruaya, a situação vivida pelos interlocutores corresponde às muitas questões que perpassam a situação dos indígenas de Altamira que vivem fora das aldeias em Terras Indígenas demarcadas, como as mudanças constantes, forçada por processos violentos ou por decisões que buscam a melhoria de vida. Essas situações evidenciam as estratégias de sobrevivência 
que exigem as mais diversas adaptações que irão, finalmente, constituir os mundos vividos desses grupos:

“Aí surgiu uma conversa, que aquela terra que nós morávamos, não era dos índios, mas a FUNAI tinha aumentado área, e esse aumento de área que foi que me derrubou. Foi que me levou a falência. Ainda hoje ainda estou na falência... Porque eu tenho toda certeza que se eu estivesse no meu lugar, hoje eu tinha. Aí eu ainda fiz um empréstimo de quatorze mil reais, mas eu não cheguei a pagar por causa da FUNAI. Porque a FUNAI que lançou a mão na terra, pros índios né, e fizeram uma indenização lá, que foi que me levou pro prejuízo. Quando nós estávamos lá eu já tinha vinte e duas cabeças de gado. Comprado com meu dinheiro que eu não devia a ninguém, e tinha duas mil mudas de pimenta do reino, que foi comprado com esse financiamento que eu fiz né. Aí do dia que completou vinte anos chegou a vistoria pra fazer a indenização lá. Aí ainda viemos aqui em Altamira correr a justiça. Mas disseram que era melhor pegar a indenização do que cair na justiça porque... É a mesma história que está do negócio da barragem agora, se o cara tiver uma casa dessa daí, se o cara não aceitar o dinheiro que querem, que eles vão dá né? Se correr na justiça perde tudo... Enrolando, enrolando, daí perde tudo. Foi a mesma história que surgiu comigo. Aí me de deram trinta mil reais, aí eu vim, eu disse: 'e a conta do banco pra pagar?' Fui no banco aí o gerente mesmo do banco falou: 'a conta do banco quem vai pagar é quem ficou com a terra'. Ai com um tempo desses, vai fazer uns dois anos que a conta veio pra cá. Levei pra FUNAI, aí de lá voltei de novo pro banco, eu disse: 'ta aqui o papel, esse papel vocês mandam pra FUNAI porque quem ficou com a terra foi a FUNAI, não foi eu não'. Aí eles disseram que iam dar outras terras pra nós, com tudo, prometeram pra nós assim: disse que iam tirar a gente dali, iam dar essa pouca indenização, mas iam levar a gente lá para o centro, que é essa terra que tem lá né. Lá nós íamos ter casas boas, estradas boas, transporte, nós íamos ter tudo, as coisas que nós nunca possuíamos nós íamos ter. Postinho, escola... Escola pelo menos, com muito trabalho o prefeito ainda fez. Fez um pedaço de estrada, mas o resto ainda está lá. E está com oito anos, já vai fazer nove anos, está lá ainda, se nós quisermos andar cinco quilômetros a pé por lote, nós temos que andar. E os outros que ficaram mais longe vão andar duas horas, três horas a pé pra chegar. Aí lotearam isso aí, aí cancelaram, disseram que pra lá não ia entrar mais ninguém. Que lá estava suspenso, que de lá ia tirar a gente colocar em outro lugar de novo... Inventaram aquela conversona. Era do Davi Rezende as terras... Daí passou, passou... Com mais de ano, chamaram a gente de novo: 'Não, vai ser loteado lá', ai eu disse: 'Mas agora ta sem jeito'. Que os invasores 
estão entrando, 'não, nós vamos tirar, que de amanhã em diante nós vamos tirar tudo'. Levou quase dois anos de novo. Agora do ano passado pra cá que tiraram os invasores, mas ainda tem invasor encrencando lá. Aí que abriram um pedaço de estrada, abriram um colégio e pronto, acabou. O resto está lá, tem uma base ainda de uns quinze quilômetros de estrada ainda pra fazer na mata. Pra lá apodrece mandioca, apodrece banana, que dava da gente trazer, mas não tem como. Aí eu estou lá. Eu tinha até abandonado o lugar porque eu disse, 'eu não vou mais', porque eu ia morar, mais os meninos, lá pra aldeia né’.

O longo trecho, além de denunciar uma série de descasos com os pequenos produtores rurais da região, o que inclui muitas famílias indígenas como a de Caneco, também expõe muitos dos fatores que compõem o cotidiano de resistência entre os interlocutores da pesquisa. Fala da intensa relação entre o rural e o urbano, aqui sob o ponto de vista do sustento das famílias indígenas, expressando os percursos dessa população, que só atualmente passou a se fixar na cidade, com o incremento das ofertas de trabalho provindas dos novos ciclos econômicos, o mais recente sendo Belo Monte. Essa relação fundamental entre o campo, incluindo o rio que ocupa uma importância incomensurável, e a cidade, caracteriza o modo de vida dessas populações que aos poucos vai sendo impossibilitada de vivenciar seus espaços tradicionais, por conta das novas dinâmicas que se impõem tanto no meio rural como no urbano.

Voltando aos indicadores numéricos, embora apresentem dados sobre essa relação da população indígena da cidade com o campo, não constam nas estatísticas as permanências nas ilhas ao longo do rio, que consistem num hábito bastante difundido entre os habitantes de Altamira. Esse costume radica-se na profunda relação que os moradores da região tem com o rio. Uma grande população mantém-se ocupando as margens do rio Xingu e seus igarapés, vivendo exclusivamente de seus recursos, são os denominados ribeirinhos, aludidos na região pelo nome de "beiradeiros". Embora esses não sejam o foco do presente estudo ressalta-se a significativa quantidade de famílias indígenas, principalmente Juruna, além de algumas famílias Xipaya, Kuruaya, Arara e Kayapó que vivem nessas condições na Volta Grande do Xingu e também a montante de Altamira. Já na cidade, embora não tendo como principal residência as ilhas e margens do rio Xingu, as famílias indígenas mantêm uma relação importante também com o rio. Mais uma vez confrontando os limites entre o rural e o urbano, a própria ocupação na cidade pelos moradores indígenas retoma os significados da relação 
com os rios e os igarapés, creditando a essa espacialização na cidade não apenas o fator de marginalização no processo urbano. As relações que os habitantes indígenas de Altamira mantêm com o rio Xingu carregam uma diversidade de significados que vão desde a reprodução material desses grupos até as formas mais próprias de afeto, denotando o respeito e a admiração que os interlocutores mantém pelo rio.

A possível tradução em números dessas relações podem ser percebidas pela importância para renda e para alimentação que a pesca representa para essas pessoas. Como pode ser observado na Figura 22 a proporção de chefes de família que tem como fonte de renda principal a pescaria representa 9,3\% sobre o total de famílias cadastradas. Contudo, segundo dados do próprio relatório do cadastramento, observa-se que a pesca, como atividade secundária tem uma representatividade muito maior. Assim, das 505 famílias cadastradas 25,5\% dizem realizar algum tipo de atividade de pesca para complementação da renda e/ou consumo próprio:

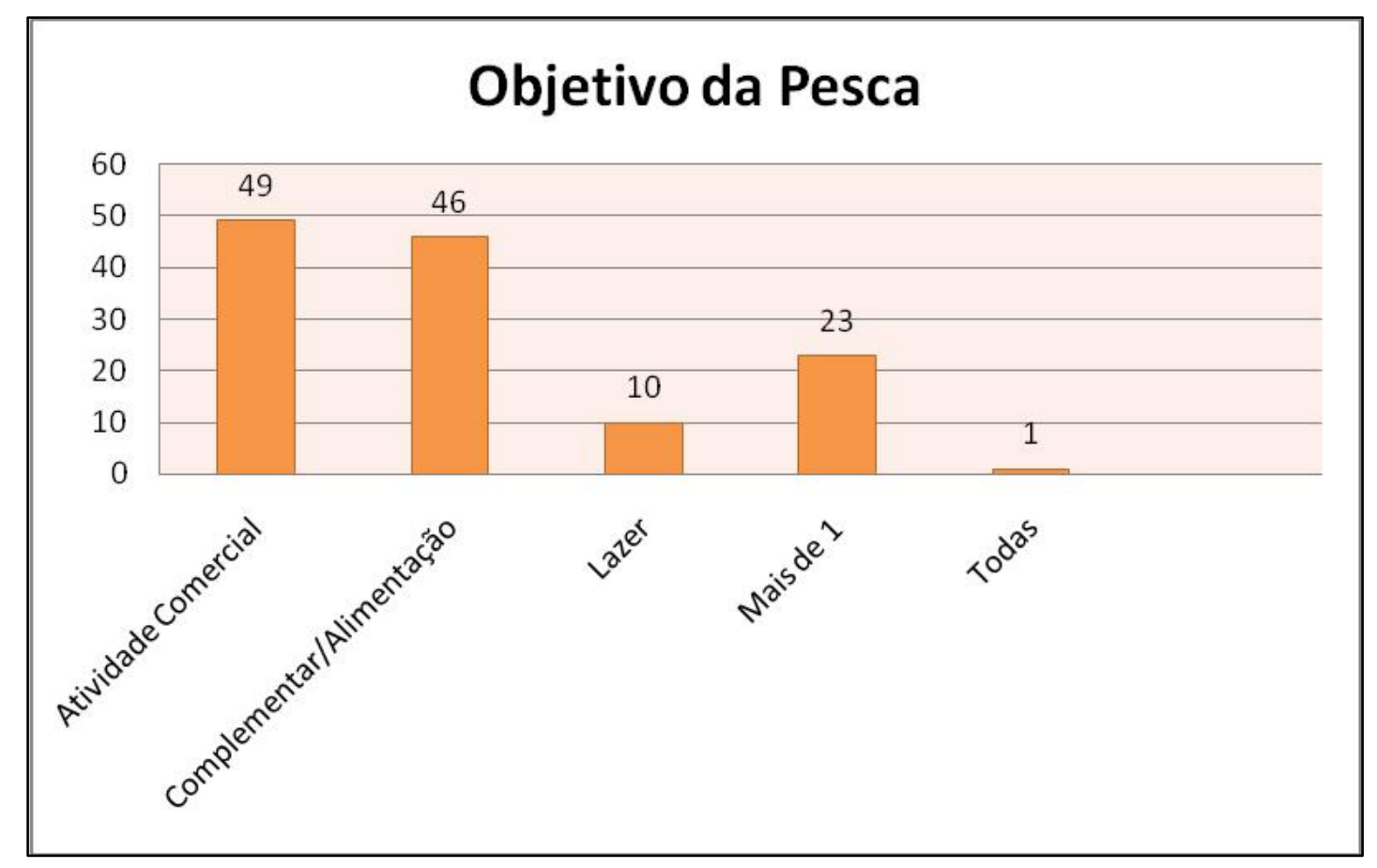

Figura 24 - Objetivo da pesca. Fonte: Relatório final de Cadastro das Famílias Indígenas (NORTE ENERGIA, 2011).

Como foi apresentado anteriormente, Caneco terminou a criação de seus filhos por meio da atividade agropecuária, somada a pesca, desenvolvida enquanto viveu no lote 
próximo à Altamira, que hoje faz parte da TI Koatinemo. Contudo a pesca é ressaltada em seu relato como sua primeira atividade comercial, aquela que lhe permitiu começar sua família na cidade e pela qual expressa profundo afeto ao descrever detalhadamente sua arte:

“Comecei mariscar nessa época... Quando arrumei ela (a esposa, Maria Kuruaya) aqui, comecei em (19)74 (...). Quando nós chegamos aqui ainda surgia esse negócio de caçada do gato né. Nós caçamos dentro do igarapé aqui, mas foi só um mês, daí voltamos logo. Já estava proibido, daí nós largamos de mão. Daí começamos na pesca, só depois que eu arrumei ela aqui, eu pesquei nove anos. Foram os anos que eu ganhei mais dinheiro na minha vida, esses noves anos... Eu ia pescar até nas Curicas, aqui pra cima... Era a remo ainda. Saia todo dia quatro, cinco horas da manhã. Não tinha tarrafa, nem rede malhadeira eu não usava, era no caniço ou na flecha. Eu saia quatro horas, quando dava três, quatro horas eu estava aqui. Já tinha vendido os peixes quase todos, começava a vender lá de cima. Não tinha patrão, nunca tive patrão, estou com essa idade, nunca tive patrão... Nessa época não tinha gelo, trazia o peixe bom, sadio mesmo. Daqui lá eram três horas de remo. Daí eu pescava até doze, uma hora, aí já cuidava de ir embora. Eu subia, subia quando chegava lá em cima já vinha descendo e pescando. Era só eu, o parceiro que eu achava no rio, mas ele andava na canoa dele, era meu compadre, o Mario Maitá, morava bem aí também. Quando ele não saia na minha frente, eu saia atrás dele, mas aqui acolá, eu ia pegando isca, pegava ele no meio de viagem, nós saiamos conversando... As vezes quando nós descíamos, topava no meio de viagem e vinha conversando de lá pra cá, até chegar. Tirava de segunda até sábado pra pescar... Tinha sábado que as vezes eu parava, então se eu não parasse quartafeira, ou quinta, então sábado eu pescava. Mas eu gostava de sair daqui doze horas, domingo, pra ir flechar naquelas ilhas ali (região da Ilha Arapujá, em frente à Altamira), nos igapós... Eu chegava lá, o sol estava quente né, entrava nos igapós tinha uns tucunaresão de filho bonito, matava só daqueles parrudões. Matava dez, doze, aí quando dava quatro, cinco horas, eu atravessava ali (região do Pepino, no bairro Independente II) onde tem essas peixarias e vendia tudo. As vezes que eu não queria trazer peixe, pra não dar trabalho pra mulher, eu trazia só o dinheiro, e nós comprávamos boia feita pra comer". 
Tendo mudado para Altamira em meados dos anos de 1970, o interlocutor descreve sua relação com a pesca como meio pelo qual pôde se estabelecer na cidade e casar-se ${ }^{51}$. Seu relato sugere as formas particulares de afeto que constituem a relação dessas populações que mantiveram tanto sua subsistência alimentar, quanto seu sustento financeiro por meio da atividade de mariscador, como também é chamada na região. A descrição da forma de pescaria apresenta um conhecimento específico do rio, alude a técnicas de pescarias (como o arco-e-flecha e o caniço - que é o anzol e linha), dando exemplos da conjunção entre as diferentes influências na composição dos hábitos e costumes entre os indígenas de Altamira, como a pesca artesanal. Destaca-se que o conhecimento sobre a pesca e o rio compreende também a identificação dos locais, como os igapós e poços, onde se encontram os bons cardumes de determinados peixes, mas também aparece na forma da indicação dos lugares de compra e venda do peixe, correlacionando dois regimes interconectados que permitem classificá-la como pesca tradicional com finalidade comercial. Vale indicar como o interlocutor ressalta o caráter emancipador da atividade, ao indicar que era livre de intermediários e patrões. Destaca-se que a menção alude às situações enfrentadas tanto por indígenas quanto por arigós quando trabalharam com a seringa, e se refaz de outras formas tanto com o trabalho assalariado de trabalhador rural, nas fazendas que crescem na região, como também na nova estrutura comercial que se consolida na cidade.

Além dessas informações apresentadas, um vasto conhecimento que envolve o complexo ecológico da atividade, como as infinitas variações das espécies de peixe e seus comportamentos, não pôde ser merecidamente explorado pela etnografia, mas é devidamente indicado como ameaçado pelas transformações iminentes. Pretende-se com essas referências apresentar alguns pontos considerados fundamentais sobre as experiências indígenas citadinas, imprescindíveis para compreender a reprodução cultural desses grupos, e que correspondem a práticas e saberes específicos:

"O verão muito seco é ruim, do tempo que eu peguei muito peixe é quando o rio começa encher. Tem ano que é mês de outubro... Mas o melhor peixe pra flecha é nessa época de mês de outubro, novembro, até dezembro. Quando chega nessas águas (no início da vazão baixa do rio), aí melhora de novo; aí já tem muito igapó, o peixe já vai entrando pra boca de piracema, aí aparece muito tucunaré. Quando alagava tudo, aí eu aquietava uns dias... Daí é

51 Sobre o casamento de Caneco e Maria Kuruaya, a dissertação irá retomá-lo a frente quando discute as genealogias dos Kuruaya em Altamira. 
pacu na seringa, na fruta de seringa. Mas eu vim usar a malhadeira de uns tempos pra cá, antes disso eu não usava não. Malhadeira ajuda, mas agora não está com nada...”.

Fonte de recursos e ao mesmo tempo símbolo da resistência política ${ }^{52}$ entre as populações indígenas e ribeirinhas de Altamira, a pesca, enquanto expressão material da reprodução cultural desses grupos, apresenta-se como ponto de grande evidência dos impactos causados ao rio Xingu com a implantação de Belo Monte e das consequentes transformações sobre os modos de vida das populações afetadas. Retendo, nesse aspecto, uma importância fundamental para compreensão da intensidade da relação que essas populações mantêm com o rio, a pesca expressa mais do que um atividade de geração de renda que poderá ser compensada com ações que amenizem os impactos causados pela obra. Sua fundamental importância na subsistência dessas populações também guarda motivos simbólicos determinantes para esses grupos indígenas da cidade, como a comensalidade que à frente será mais bem detalhada pela dissertação. Nesse momento cabe oferecer as apreensões e receios que o empreendimento impinge sobre aqueles que exercem essa atividade, como alerta Caneco:

"Estou pescando, aqui acolá... Que agora não tem mais peixe pra flecha! Não tem mais não, acabou... Acabou mais por causa da empresa (barragem)... Sujou a água, e essas bombas que mexem o rio, o peixe escuta. Ali naquele lago ali, perto daquele aterro grande que vocês andaram, ali tem ariduia, aquele peixe do tamanho de uma curimatá grandona assim, aí você olha ali no verão, chegam a estar de cabeça pra cima chupando aquele lodo da água... É bom de matar. Nós matávamos muito ali, agora não boiam mais. Mas o advogado da empresa disse que melhorou de peixe, mas pra ele! Mas pros pescadores não... O peixe, o atravessador da beira do rio compra barato da gente, agora pra gente comprar está caro demais! Subiu, está dezoito reais o quilo do peixe. Ontem eu botei um tucunaré desse tamanhinho, deu trinta e seis reais, eu disse 'não deixa aí, que passou do dinheiro... '. É muito

\footnotetext{
52 A caça, e principalmente seu consumo, consiste em outro costume disseminado entre os indígenas da cidade. Contudo, como pôde ser observado pelos dados estatísticos apresentados, não aparece como uma atividade de geração de renda para essa populações, uma vez que é proibida por lei. Mesmo assim, durante os campos realizados foi possível identificar a importância do consumo de caça, na maioria das vezes compradas de outros indígenas, parentes das aldeias Xipaya, Kuruaya e Juruna, ou de outras etnias, além daquela trazida das expedições de pesca ou durante a abertura da roça por exemplo, que não visam a caça para comercialização, apenas para consumo. Em outro momento, a dissertação abordará aspectos da alimentação das famílias na cidade que incluem muitas receitas a base de caças e de pescados.
} 
caro o peixe... Do tempo que eu vendia peixe barato aí eu ganhei muito dinheiro. Mas agora o peixe está dando dinheiro, mas você não pega não. Você faz uma despesa de duzentos reais pra ir ali na ilha que eu estou né, pra ir pescar, se você brincar você não tira o dinheiro. Está ruim... Eu até que parei, esse ano já peguei muito pouco”.

A pesca, enquanto atividade resistente entre os indígenas da cidade, também recupera as contradições e tensões inerentes aos elementos que caracterizam as situações de vividas pelos indígenas na cidade: traz consigo os limites das distinções entre o urbano e o rural, entre aquilo que pode ser considerado como especificamente tradicional em meio à contextos assumidos como modernos; e reitera a opacidade dos contornos que distinguem os habitantes indígenas e não indígenas que dividem os espaços da cidade, onde isolar costumes e hábitos não permite qualquer conclusão sobre formas de pensamento ou práticas que acessem noções de identificação e distinção para essa populações. No âmago dessa suposta inconsistência dos elementos apresentados, que constroem um recorte das condições em que vivem as populações indígenas de Altamira, repousam os deflagradores das formas específicas com que os interlocutores criam suas estratégias de sobrevivência frente às transformações trazidas de fora e do alto. Não obstante, todo esse movimento é também auto-informado, uma vez que são as alianças e conflitos entre aqueles com quem se coabita e se convive diariamente que promovem inflexões capazes de inventar e reinventar as estratégias de sobrevivência.

Pensar em sinais indentitários, enquanto expressões de tradições que mantiveram-se intocáveis frente aos processos de contato e troca, ou mesmo às transformações inerentes ao longo do tempo, não é mais um esquema com o qual a antropologia se satisfaz para compreensão das diferenças culturais. Assim determina-se o olhar para as situações de indígenas que residem nas cidades. Embora a formação do pesquisador tenha sido orientada a não incorrer na exotização de seus interlocutores, uma estranha persistência, talvez entranhada nas formas dos manuais lidos e não seguidos a risca pelos antropólogos atuais, prescreve métodos que podem trazer o desconforto de perguntas que parecem descontextualizadas para as situações da pesquisa. Nesse sentido algumas opções se repetem: julga-se apenas a destruição das culturas indígenas, em que a ruptura com laços passados é 
inevitável e fatal (opção em desuso); ou celebra-se a renovação, conferindo à mudança, se não o lugar empiricamente positivo para os indígenas, mas teoricamente vistoso, capaz de criar sob os escombros (resposta que é fruto de controvérsias, contudo disseminada). Tanto para uma como para outra, é necessário dar um sentido muito próprio a um efeito que é bem caro ao pensamento do qual somos herdeiros: a mudança. Se em todos esses casos a história parece tomar de assalto os grupos indígenas, isso ocorre porque não nos parece possível existir continuidades, a menos que se viva no ideal idílico do passado tradicional.

A tentativa até o presente momento da dissertação foi de expor as limitações inerentes aos instrumentos metodológicos do pesquisador quando aborda a descrição das situações em que se encontram os grupos indígenas que residem na cidade de Altamira, principalmente a partir dos indicadores socioeconômicos apresentados. Caracterizando situações que soam bem distantes de "contextos tradicionais", os dados sobre distribuição espacial, habitação e atividades econômicas parecem descrever apenas um quadro de assimilação, perfeitamente aplicável aos vizinhos não indígenas que convivem nos bairros periféricos de Altamira. Como evidência inquestionável para desfazer qualquer intenção romântica sobre a preservação dos costumes ancestrais (como sinais de pureza cultural) esses servem perfeitamente para caracterizarmos os indígenas na cidade. Contudo, se localizados teoricamente apenas como reposta à certa insensibilidade pela qual a antropologia já passou, profetizando a extinção dessas culturas, inevitavelmente recai-se sobre o privilégio da transformação, criando um retrato analítico incapaz, mesmo sem ter essa intenção, de ponderar as persistências culturais, ou seja, ouvir de seus interlocutores não porque voltaram a ser, mas sim porque continuam índios. Abandonar o recurso analítico da distinção, como exigência externa, parecerá contraditório se for mantida a ideia de que para falar de indígenas nas circunstâncias em que se encontram os que residem em Altamira é preciso reduzir a história como tragédia das perdas do contato, ou como redenção da reinvenção. A destruição já ocorreu: grupos indígenas foram completamente aniquilados durante a conquista da América e seus desdobramentos, e a história indigenista sabiamente não nos deixa esquecer. A reinvenção está sendo contada: a visibilidade dos indígenas que passaram pelo intenso contato se deu por meio da abertura política democrática, que promove a proteção legal dessas culturas permitindo que essas reivindiquem suas identidades e seus direitos, um significativo avanço de nossa época. Para pesquisa, não repetir os recursos analíticos citados consiste menos na intenção em discutir e criticar teorias consagradas do que localizar a necessidade de acompanhar de perto as expressões e manifestações ouvidas e observadas em campo. Por isso 
optou-se pelos relatos e memórias dos indígenas idosos sobre a mudança e permanência na cidade; por isso foram privilegiadas as descrições do espaço urbano da cidade, referindo-se às condições de habitação e reprodução material com os sentidos providos pelos interlocutores da pesquisa.

Esse alerta tem o norte claro que foi determinado pela experiência em campo, caracterizada pela percepção da ausência da polêmica do "ser ou não ser índio" entre os indígenas da cidade, daquela formulada por meio de critérios baseados em sinais diacríticos. Quando a "indianidade" está em jogo, essa tem a ver com um inquérito certeiro, que tende a subjugar qualquer outro: é filho, neto, bisneto de quem? Ora, o que coloca-se diante do pesquisador, nessas situações encontradas em campo, relaciona-se com transmissão e continuidade, parentesco como diacronia enfatizando heranças das quais se é destituído apenas com a aniquilação. Contudo, essa descendência não se traduz na rigidez da tradição canônica, tem uma consistência própria que parece acontecer não por meio, mas através do tempo, ou seja, permite coesão e coerência à organização indígena na cidade, ou em qualquer lugar por onde passem, como uma resistência despreocupada com permanência. A cidade então, como nos sugere Andrade (2010), deixa de ser um ambiente exclusivamente desagregador para os indígenas que nela habitam, conforme determinadas visões enfatizaram, permitindo, no limite, modos de existência desejado pelos interlocutores. Se a antropologia hoje não precisa responder (para si mesma?) o que é ser indígena, seja na aldeia ou na cidade, quando discutimos cultura podemos avançar e compreender de mais perto o que está sendo dito e repetido, feito e refeito pelos sujeitos da pesquisa, como afirma Nunes: "Estando em outro ambiente, a vida que se leva certamente não é mais a
mesma, mas a lógica por trás das "ações, das relações e das condutas"
continua sendo a lógica da família extensa, ou talvez poder-se-ia dizer, da
produção do parentesco". (NUNES, p. 20, 2010)

Por isso buscar diferença ou mudança não é um procedimento em si mesmo para a pesquisa - assim como buscar identidade ou continuidade também não deve ser -; porque aos seus interlocutores essas questões surgem sob outras formas e pesos, como são enunciadas as dificuldades em contornar as incontáveis perdas, que cada história pessoal de sofrimento relata, e também são reconhecidos os ganhos oriundos das estratégias necessárias para a sobrevivência. A dissertação segue, assim, discutindo parentesco: casamentos, genealogias e casos de famílias nos bairros de Altamira. 


\subsection{Casamentos}

Dados sobre casamentos entre os indígenas da cidade de Altamira também foram apresentados tanto pelo EIA/RIMA componente indígena citadino (2009) como pelo Relatório de Cadastramento das Famílias Indígenas (2011). As informações apresentadas caracterizam a origem dos cônjuges, classificados entre as etnias indígenas ou como não indígenas, como pode ser observado a seguir:

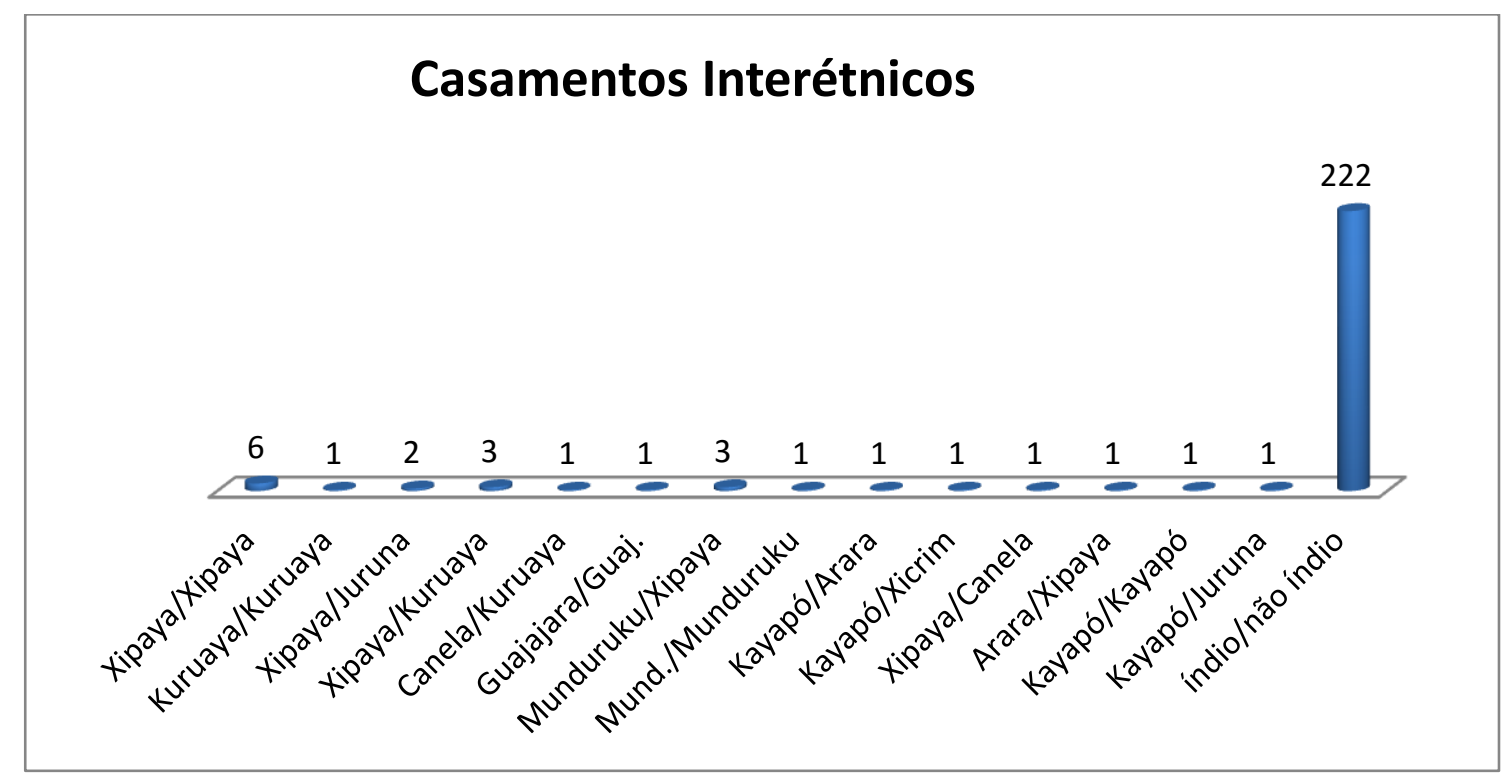

Figura 25 - Casamentos Interétnicos 1. Fonte: EIA/RIMA Componente Indígena Citadino, 2009. 


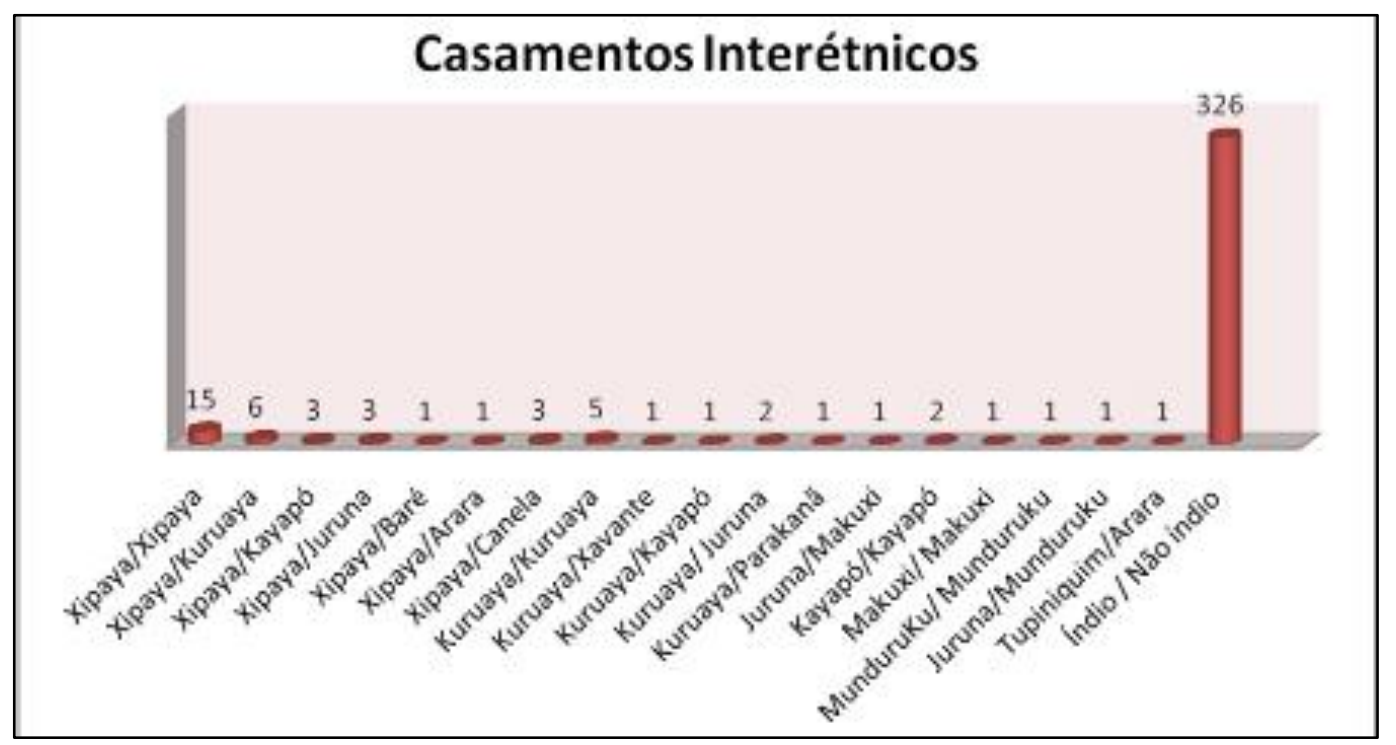

Figura 26 - Casamentos Interéticos 2. Fonte: Relatório final de Cadastro das Famílias Indígenas (NORTE ENERGIA, 2011).

Enquanto evidência, verifica-se a situação disseminada de casamentos entre indígenas e não indígenas residentes na cidade de Altamira atualmente. A situação surge como um ponto fundamental para pensar a condição indígena na cidade, para além de dialogar com a necessidade de rever conceitos essencialistas de cultura, criticar os paradigmas da aculturação na antropologia - de modo a desfazer a noção de grupo étnico enquanto unidade portadora de cultura - ou de desagregação no espaço urbano, perspectivas que localizariam o casamento interétnico exclusivamente como disrupção. A natureza dos casamentos, como concepção e prática nativa, entre os principais grupos indígenas que compõem a população altamirense, lança luz sobre como esses populações se situaram ao longo do tempo nos processos de ocupação e desenvolvimento dessa região, ou seja, como foram elaboradas as estratégias próprias a partir do conjunto de transformações que se abriam com o intenso contato com as populações não indígenas. Percorrendo os significados específicos da origem, ou "raiz" indígena, como expressam alguns interlocutores, é possível acessar certos sentidos fundamentais que dão pistas sobre os modos próprios das experiências indígenas na cidade. Nesse espaço urbano, as referências ao parentesco se encontram com os fatores não só de coabitação e convivência com não indígenas, mas também de aliança. Essa exploração deverá mostrar como os termos família, casamento e parentesco são fundamentais para pensar a constituição sociocultural entre os indígenas de Altamira, que é também o modo de relação com não indígenas de diferentes origens. 
À etnografia o tema do parentesco se apresentou imediatamente, partindo do próprio modo como a pesquisa de campo foi se conformando, a partir das circunstâncias de trabalho anteriormente apresentadas $^{53}$ do trabalho de registro e recuperação da história oral na região de Altamira. Assim, ao falar sobre a história da região e da cidade de Altamira era inevitável aproximar-se dos grupos indígenas que mais intimamente estiveram ligados a essa história, ou melhor, cuja posição dentro desses processos pode ser caracterizada pelo intenso e longínquo contato, concebendo uma condição particular e muitas vezes ativa desses indígenas nesse cenário (tanto quanto é a de outras populações, como os migrantes nordestinos, "arigós" também invisíveis nas histórias oficiais). Aproximando-se dessas histórias, por meio das memórias das pessoas idosas ${ }^{54}$, ficou cada vez mais evidente a maneira como as trajetórias pessoais se inseriam no esquema de importância para o registro das versões indígenas: as pessoas foram chamadas a contar suas histórias num critério que mobilizava tanto a autoridade sobre a memória correta dessas histórias, consistindo na maior parte do tempo no domínio da "tradição indígena", por assim dizer, que, por sua vez, circulava na dimensão pública entre as famílias da cidade de modo geral. A primeira vista, esse pereceu um critério único, mas também foi preciso compreendê-lo dentro de um quadro que relaciona famílias extensas, no qual as versões históricas operam sobrepondo-se, ou mesmo questionando-se mutuamente, dentro do anteparo da esfera privada das famílias. Embora cada versão histórica não apresentasse discrepâncias gritantes quanto ao conteúdo dos episódios fundamentais que marcaram a história dos Xipaya e Kuruaya, a cada momento surgiam alegações do tipo: “Agora que ela contou a história da família dela, eu vou contar a da minha..."; "Fulana é filha de Ciclano, mas não sabe contar a história..."; "Agora ela quer falar da história, mas quando era moça nem ligava...", entre outros exemplos de como as versões históricas sobre os grupos perpassam pela compreensão da família como valor.

Nesse contexto, a observação das genealogias familiares foi o recurso etnográfico que permitiu a mediação entre história e trajetória pessoal de cada entrevistado com os valores de família e parentesco, que preenchem alguns dos significados dados pelas experiências indígenas na cidade. Partindo das genealogias iniciadas pelos estudos ambientais ${ }^{55}$, a pesquisa aproveitou tanto a informação objetiva dos grupos familiares interlocutores, como essas

\footnotetext{
${ }^{53}$ Ver: Introdução.

${ }^{54}$ É preciso indicar que os relatos, que seguem no presente subitem, não estão acompanhados da referência a idade dos interlocutores por não haver precisão nas datas de nascimento na maior parte dos casos. Dessa forma, optou-se apenas pela indicação de que se trata de pessoas idosas - referidas como matriarcas e anciões Xipaya e Kuruaya - ou, em outros casos, filhos adultos desses reconhecidos antepassados.

${ }^{55}$ Ver: EIA/ RIMA (Eletronorte, 2009).
} 
informações também auxiliaram durante a pesquisa de campo no estreitamento das relações com os sujeitos da pesquisa, seja no sentido de explorar e aprofundar o conhecimento junto daqueles que acompanhavam esse interesse da pesquisa (corrigindo e ampliando os diagramas), ou mesmo como meio do pesquisador demonstrar esse conhecimento privado a cada família (embora já publicizado nos relatórios) que por vezes proporcionou importante acessos, como a participação em diálogos sobre as dimensões das famílias extensas (quem era filho, irmão, ou tio de quem, por exemplo). O valor metodológico dos diagramas de filiação e aliança advém dos modos que os próprios sujeitos valorizam suas histórias familiares, e assim pela fundamental qualidade em permitir acessos, compartilhando e suscitando com as pessoas o mesmo interesse sobre sua história e de sua família. Além desses, as genealogias produzidas pelos antropólogos, outros pesquisadores, e mesmo os próprios indígenas, foram se desenvolvendo como instrumentos de luta pelo reconhecimento dos direitos indígenas dos moradores da cidade, e também passaram a incorporar o próprio manejo corriqueiro nas controvérsias sobre o pertencimento étnico entre os interlocutores. Sobre a contribuição das genealogias para o debate público, efeito de grande implicação política, serão privilegiados nesse primeiro momento os pontos de vista internos, ou seja, sua repercussão sobre as formas de reciprocidade e conflito entre os interlocutores, para posteriormente serem retomadas suas ligações mais estreitas com os agentes do movimento indígena e da política institucional não indígenas $^{56}$.

Desde já é interessante indicar como a representação gráfica dos casamentos e genealogias, compartilhada com os interlocutores, ilustrou tanto situações de aproximação como de distanciamento entre as famílias. Situação comum era ouvir a referência, ou mesmo surpresa da descoberta, de um parente em comum, enquanto a ascendência reclamada era tratada como fator particularizador da origem, operando quase como uma propriedade familiar na definição do pertencimento. Ao mesmo tempo cisões internas competem pela competência sobre a herança, expressando conflitos intrafamiliares agravados pelo contexto de construção da barragem, que criou canais de assistência disputados pelos interlocutores. Embora a situação da usina seja urgente na atual situação pela qual passam essas pessoas, a etnografia opta nesse momento por explorar as faces anteriores e mais intimamente vinculadas aos sentidos nativos dessa experiência familiar coletiva, embora ressalta-se que a mesma não possa ser destituída das transformações trazidas pelo atual contexto.

\footnotetext{
${ }^{56}$ Ver: Capítulo 4 da dissertação: A política indígena na cidade de Altamira: desafios antes e durante Belo Monte.
} 
A princípio, o argumento aqui vai ao encontro da compreensão de como esses diagramas genealógicos expressam traduções de valores de parentesco entre os Xipaya e Kuruaya de Altamira. Seria preciso neste momento dialogar com um vasto campo do debate antropológico, mais especificamente, o do parentesco na etnologia ameríndia. Recuperando apenas um fragmento desse amplo debate - cujo mapeamento foge do alcance da dissertação pretende-se situar o valor das genealogias exploradas, não somente para os interlocutores da pesquisa como para o próprio rendimento teórico do estudo. Sendo assim, destaca-se como o debate sobre parentesco avançou intensamente sobre a suposta antecedência atribuída à consanguinidade - intrínseca mesmo nos muitos discursos construtivistas - demonstrando como a lógica da aliança é estruturante dos sistemas de parentesco ameríndios. Na asserção fundante de Lévi-Strauss (1958):

"Um sistema de parentesco não consiste nos laços objetivos de filiação ou de
consanguinidade entre os indivíduos. Ele só existe na consciência dos
homens; é um sistema arbitrário de representações, e não o desenvolvimento
espontâneo de uma situação de fato". (LÉVI-STRAUSS, 1958, p. 61).

A propósito do tema, houve fundamentais desenvolvimentos posteriores ancorados sobre as questões da aliança propostas por Lévi-Strauss, sendo que, dentre essas, destaca-se nessa breve recapitulação as formulação de Viveiros de Castro (1993; 2002) sobre a importância da afinidade potencial nos sistemas de parentesco ameríndios na Amazônia. Nesse sentido, o autor desenvolve a questão lévi-straussiana elevando a ideia de afinidade potencial - formuladora de consanguinidades e afinidades efetivas - enquanto princípio criador de relações de influências mútuas entre entes, menos afeito aos modelos de estrutura de posições associadas a direitos sobre coisas e pessoas, tal qual as teorias da descendência enfatizaram. Distante das condições de retraçar o debate, sublinha-se que a etnografia foi inspirada por essas teorias que "desnaturalizaram" o parentesco, demonstrando como esse é uma expressão de princípios de criação de relações, muito mais do que forma definida por qualidades extrínsecas.

Ao mesmo tempo, o presente estudo é também influenciado pelas discussões contemporâneas que restituem o parentesco como categoria fundamental para antropologia, porque é também para seus interlocutores, e porque assim traz de volta à disciplina a possibilidade de comparação, enquanto categoria estável, ou seja, que não é ausente de 
efetividade a despeito de sua construtibilidade ${ }^{57}$. Acompanha-se a reflexão de Sahlins (2011) que, grosso modo, debate com as leituras reducionistas que pensam a filiação como natureza e a aliança como cultura, o que, por fim, reiteraria uma suposta distinção entre o espaço exclusivamente biológico ou social do parentesco. Como ele argumenta:

\begin{abstract}
"I argue that 'mutuality of being' will cover the variety of ethnographically documented ways kinship is locally constituted, whether by procreation, social construction, or some combination of these. Moreover, it will apply equally to interpersonal kinship relations, whether 'consanguineal' or 'affinal', as well as to group arrangements of descent. Finally, 'mutuality of being' will logically motivate certain otherwise enigmatic effects of kinship bonds - of the kind often called 'mystical' - whereby what one person does or suffers also happens to others. Like the biblical sins of the father that descend on the sons, where being is mutual, then experience is more than individual". (Sahlins, p. 3, 2011).
\end{abstract}

Conquanto a etnografia não sirva-se explicitamente da categoria sahlinsiana de "mutuality of being", esta é inerente aos sentidos de pertencimento, compartilhamento, união, reciprocidade e identificação que a etnografia mobiliza na análise das concepções e práticas nativas de parentesco. Ao passo que todas essas noções constroem relações cujo sentido e aplicação são dadas igualmente por exclusões, segmentações, dispersões, conflitos e distinções. Então, se as representações do parentesco Xipaya e Kuruaya falam de continuidade por meio da genealogia elas também dizem muito sobre as transformações históricas por que passaram esses grupos, por meio dos matrimônios entre os diferentes grupos e com não indígenas. As realizações do parentesco entre os interlocutores são capazes de criar referências de identidade, que demarcam diferenças, mantendo de espaços de reafirmação que atualizam laços afetivos compartilhados.

Essas ponderações são imprescindíveis para orientar a apresentação, que seguirá a dissertação, dos episódios e explicações do parentesco Xipaya e Kuruaya. Pois, assim como

\footnotetext{
${ }^{57}$ McKinley (2001:44) reproduz o seguinte trecho da carta de Lévi-Strauss para Schneider: "Tendo enviado a Lévi-Strauss uma cópia de seu texto 'What is kinship all about?', em que afirma que "parentesco" é um 'nonsubject', como totemismo, matriarcado, complexo matrilinear, etc., e que não existe em lugar nenhum, a não ser na mente dos antropólogos, David Schneider recebe as seguintes palavras de agradecimento2: 'Muito obrigado por me mandar 'What is kinship is all about ?'. Embora eu concorde com você em muitos pontos, não iria tão longe em dizer que parentesco é um 'non-subject'. Eu o definiria como um modo de classificar pessoas e definir seus direitos e obrigações de acordo com casamentos passados e com previsão de futuros. Esta formulação é muito desajeitada porque nada é mais difícil que frasear uma definição em uma língua estrangeira, mas estou certo de que você vai captar meu ponto, que é o de que parentesco tem a ver com casamento e que proibições, prescrições e preferências matrimoniais não são um 'non-subject'.".
} 
sugere Sahlins (2011) sobre o peso da experiência supra-individual do parentesco, é necessário à etnografia lidar com consequências das atualizações das questões suscitadas pelo parentesco que circulam entre os interlocutores como formas de redefinição das subjetividades indígenas. Assim se configura, por exemplo, a relação que o pesquisador teve com Cláudio Kuruaya, importante liderança da cidade que, retornando depois de longo período distante de Altamira para encampar a defesa de sua família contra os impactos causados por Belo Monte, assumiu uma responsabilidade muito maior na defesa dos direitos da população atingida pelos impactos da obra ${ }^{58}$. No caso específico da história pessoal, a referida liderança buscou recuperar suas heranças indígenas na família, não obstante sua mãe, que lhe deixou a raiz Kuruaya tenha falecido quando tinha apenas 11 anos. Nesse processo de autoafirmação da identidade indígena no espaços públicos, que envolvia disputas com outras lideranças e agentes da política indigenista de Altamira, houve muitas cobranças sobre suas origens que também se internalizaram na necessidade de restituição das lembranças familiares afetivas, como o fez rememorar as pescarias de arco-e-flecha com seu tio, por exemplo. Esse pequeno excerto, demonstra quantas sobreposições compõem o movimento de identificação com a herança indígena, quando pensado dessa forma, entre os interlocutores. Por sua vez é também um movimento que retém as estratégias de sobrevivência das pessoas, que são refeitas e reconfiguradas segundo o momento histórico em que vivem, e hoje permitem, ou até mesmo cobram, a valorização da origem indígena. A densidade em torno das preocupações sobre como viver bem caracteriza tais incursões políticas, tanto quanto foram e se mantêm os contingenciais casamentos interétnicos, mesmo com seus ainda perigos inerentes. Essa complexidade de fatores justifica a dificuldade em se simplificar a discussão sobre casamentos, misturas, genealogias e heranças, recaindo sobre a instrumentalização da identidade; significa alertar o desafio que é responder o que determina, quais os objetivos, e as posteriores consequências de processos que se apresentam como autoafirmação, mas convergem, no limite, para um amplo horizonte de criação e renovação. Como sugere Gow (1997):

"Desejo tornar mais explícito um postulado teórico que subjaz a esses
trabalhos, a saber, que o parentesco é, acima de tudo, um sistema de
subjetividade, pois as estruturas básicas da consciência humana envolvem
necessariamente a consciência de um eu [self] em meio aos outros". (GOW,
p. 39, 1997).

${ }^{58}$ Alguns pontos dessa biografia em particular serão retomados no próximo capítulo, na discussão sobre o movimento indígena em Altamira. 
A citação do excerto do autor é mais um chamado às contribuições da etnologia indígena que inspiram a questão apresentada pela etnografia. Ao enunciar o problema como autoafirmação o breve trecho que descreve a situação da liderança Kuruaya ressalta a face comunicante desse processo de subjetivação, ou seja, nada mais faz a não ser indicar as respostas dos sujeitos à questão que se apresenta, seja ela proposta pelos agentes do Estado, pelo antropólogo ou por outras lideranças indígenas. Se a autoafirmação adquire então a proeminência da afirmação para alguém, ela tende a tomar a forma de questão sobre identidade, criando o impasse: usar instrumentos analíticos que privilegiam os fenômenos culturais em termos de identificação e não de distinção, como um projeto ego-referenciado de formação da consciência de si em detrimento da consciência do outro. Assim me parece que determinado legado analítico de categorias de identidade étnica tem uma grande dificuldade de tradução dos pontos de vista nativos que versam sobre identificações porque essas são, no limite, categorias que se autopropõem.

Se a "cultura com aspas" (Carneiro da Cunha, 2009) é fundamental par pensar as implicações da política não indígena sobre as concepções e práticas dos interlocutores da pesquisa, essa dimensão explica muito mais os acentos e reticências dos discursos militantes da categoria índio citadino, do que fala sobre um possível (é possível?) "ser" Xipaya e Kuruaya. Embora possamos falar desses grupos como ressurgidos, ou classificar seus processos de reivindicação de direitos à autodeterminação como "etnogênese" (Oliveira, 1998) não parece ser essa a única preocupação envolvida, mesmo quando diretamente influenciada pelos dispositivos que se construíram em torno dessas asserções de autoreconhecimento e reconhecimento comunitário. Nesse momento, a dissertação, envolta em seu material etnográfico, se viu impelida a perscrutar espaços menos visíveis, muitas vezes entreditos, do que parece aproximar-se dos chamados sentidos nativos desses movimentos de autoafirmação: são veiculados em espaços públicos e privados que articulam inquietações, convergem experiências e propõem alternativas orientadas pelo desejo de viver melhor. Admitindo a experiência Piro anunciada por Gow (1997):

"O que teríamos de definir como parentesco, para os Piro, é esse "viver bem" (...). Meu finado compadre Artemio Fasabi, da aldeia de Santa Clara, assim exprimiu certo dia a essência do "viver bem": "Eu nunca poderia ir viver longe daqui. Isso seria o mesmo que morrer. O que é a morte, senão que você nunca mais poderá ver seus parentes, seu pai, sua mãe?”. (GOW, p. 56-57, 1997). 
Esse "melhor" em transformação é o que a etnografia propõem perseguir lembrando de memórias familiares (que são trajetórias pessoais) de dor e sofrimento contadas sempre com o bom humor pelos interlocutores.

\subsubsection{Genealogias indígenas de Altamira}

Seguindo os passos das genealogias das famílias da cidade, enquanto dados de finalidade pontual, observamos recorrências muito importantes para a compreensão do universo indígena de Altamira. A primeira reitera o dado estatístico apresentado no início do capítulo: refere-se à predominância dos casamentos entre indígenas e não indígenas. Ao mesmo tempo fornece outro aspecto dessa evidência: a grande maioria desses casamentos é de um homem não indígena e uma mulher indígena. Durante a investigação histórica, experimentada no Capítulo 2 da dissertação, os relatos das trajetórias de vida sugeriam a generalização dessa situação ao falaram sempre do "marido" migrante, geralmente nordestino arigó ou da época de construção da Rodovia Transamazônica. As aspas no marido referem-se ao teor comum dessas histórias de conjugalidade, principalmente aquelas dos tempos dos ciclos da borracha, quando a vida ainda era no alto, nas terras dos rios Iriri e Curuá. Ao falarem dos homens com quem se "amigaram" ou "ajuntaram", lembram claramente que naquele tempo não se casava. A afirmação, vinda de muitas idosas sempre amigadas com homens não indígenas é também acompanhada de referências pouco afetivas ao marido e as vezes mesmo ao pai não indígena. Deve-se admitir que a ausência de afetividade é muitas vezes um estranhamento deslocado perante nossos próprios comportamentos familiares. Ao mesmo tempo essa "ausência" é reveladora de um outro modo de expressão dos cuidados e carinhos. Contudo esse traço não deve ser confundido com os distanciamentos enunciados para muitos dos casamentos descritos por essas idosas, que em grande parte acabaram por se amigar mais de um vez.

A genealogia da família de Maria Augusta Xipaia, mais conhecida como Xipainha, e reconhecida liderança Kuruaya na cidade de Altamira, e sua irmã mais velha, Ana Kurica são casos exemplares: 


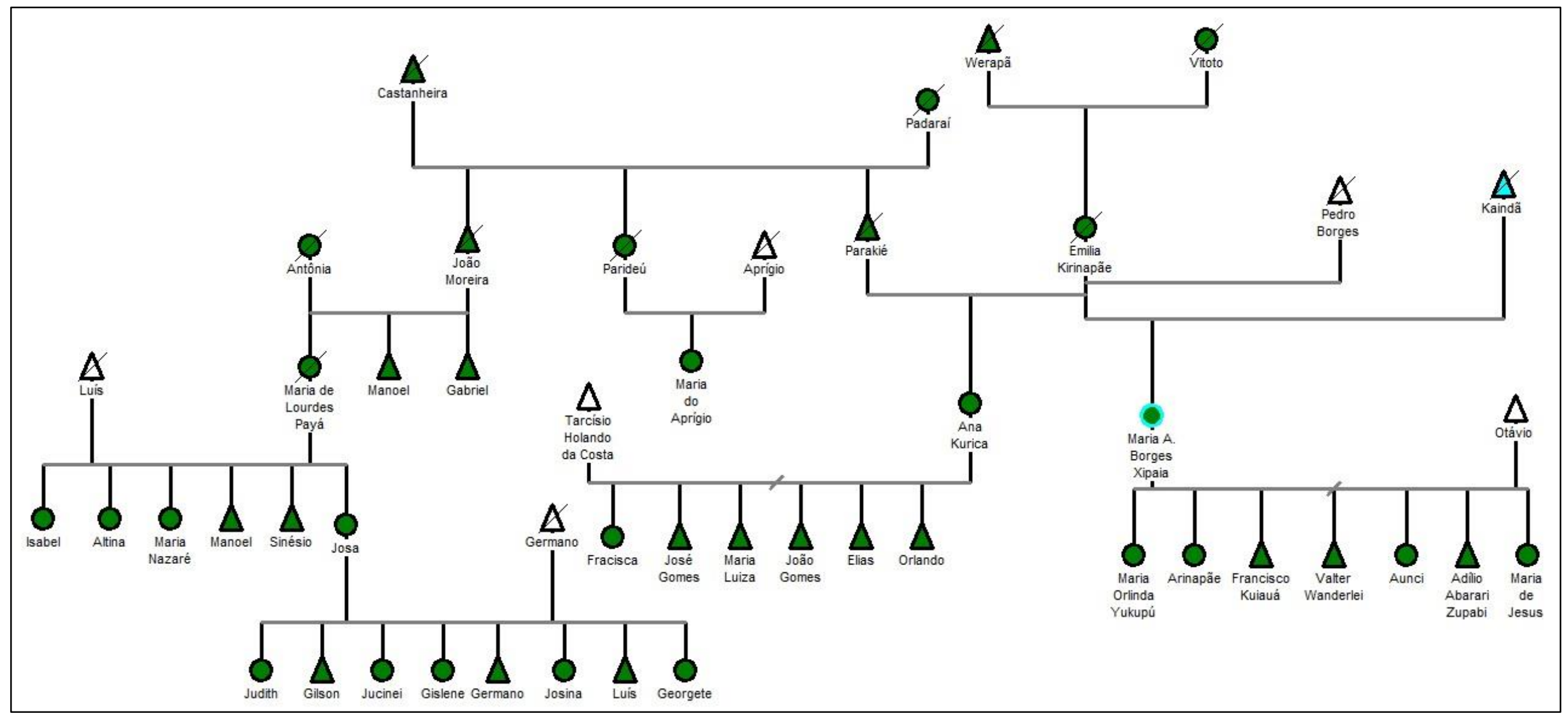

Figura 27 - Genealogia Kirinapãe e Payá. 


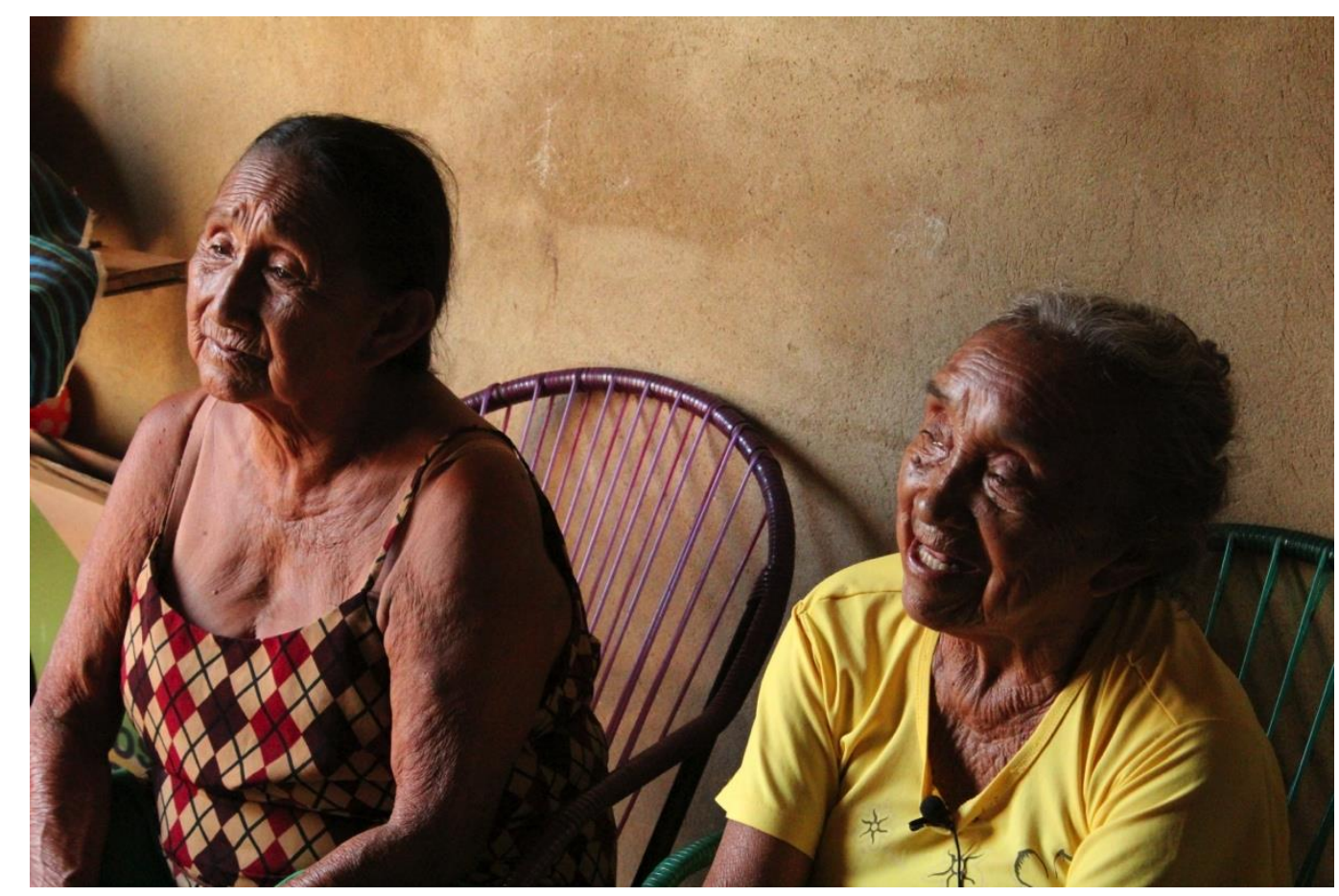

Figura 28 - Da esquerda para direita, Xipainha e Ana Kurica, matriarcas Kuruaya - 2015

Como é possível observar, a mãe de Xipainha e Ana Kurica, chamada Emília Kirinapãe era Kuruaya. Se perguntada, Xipainha dirá que também é Xipaya, embora "não conheça a cultura Xipaya", como diz, só tendo aprendido as histórias e cantos dos Kuruaya com sua mãe. Relata nunca ter conhecido seu pai, o Xipaya Kaindã, um famoso guerreiro que tinha, segundo contam, muitas mulheres e nunca foi casado com sua mãe. Na genealogia também aparece o padrasto que criou Xipainha, Pedro Borges, que era soldado da borracha, e nas palavras da mesma, "virou um tuxaua dos índios". Da forma como conta, seu padrasto conquistou essa posição pois arregimentava os indígenas no trabalho nos seringais, transformando-se em seringalista. Pedro Borges era casado com uma Xipaya que havia falecido quando os Kuruaya do grupo de Kirinapãe, fugindo dos Kayapó se aproximaram dos seringais.

Antes de conhecer o seringueiro, Kirinapãe era casada com o Kuruaya Parakié, com quem teve outros filhos - Guabiraba, outro homem de nome desconhecido - e Ana Kurica, cerca de vinte anos mais velha que Xipainha e a quem a mesma considera como segunda mãe. O casamento entre Kirinapãe e Parakié ainda tinha acontecido nas velhas aldeias dos Kuruaya, na região dos rios Curuá e Iriri, próximo aos igarapés Sabugi e Pitchatcha. Parakié morreu durante o período de ocupação dessa região para exploração da seringa, um momento 
em que as doenças e os conflitos dizimavam os indígenas da região. Quando Kirinapãe conheceu Pedro Borges estava grávida de Xipainha, dessa forma a mesma foi criada como filha pelo seringueiro. Com Pedro Borges, Kirinapãe teve apenas uma filha, Antônia Borges.

Sobre seu casamento, Xipainha não apresentou muitos detalhes, mas oscila expressando a parceria para criação dos filhos e uma vez revelou que "não casou por amor, $e$ não casaria novamente de jeito nenhum!" Para compreensão dos sentidos retidos nessas situações conjugais, que permitem tanto pensar sobre os significados atuais da autoafirmação étnica, bem como destacar aspectos de uma sociologia das relações de parentesco entre as famílias indígenas de Altamira, é fundamental recuperar as formas de enunciação dessas situações de casamento, que, como dito anteriormente, são qualificadas na maioria dos casos pela expressão "amigar”. Assim conta Ana Kurica sobre sua vida conjugal, após seu primeiro marido, cearense soldado da borracha com quem casou-se quando ainda vivia no seringal:

"Quando nós chegamos aqui (Altamira) ele só vivia bebo! Até que um dia enjoei dessas coisas. Aí não quis mais ele não. Daí ele prometia de me matar... Mas não matou nada! Agora esse daí (o segundo marido), toda vida foi virado! Nossa casa era lá no ferro-velho, por debaixo era cheio d'água. De manhã cedo, coitadinho, ele peitava n'água para ir vender as coisas dele. Depois ele arranjou uma mais bonita do que eu e foi embora! (risos)".

Enquanto parte da história dos Kuruaya, a posição da mulher indígena durante esses períodos de migração pendular, que eram caracterizados pela condição precária de vida, com os conflitos que resultavam em mortes e outras opressões, não pode ser descrita a partir de amenidades. Contudo a percepção das indígenas sobre sua situação vivida é determinante para acompanhar os matizes desses "encontros" que construíram as alternativas dessas populações. Nas falas das duas matriarcas Kuruaya é sensível como a condição desses indígenas é paradoxal: enquanto a história do alto é lembrada sob a tônica da guerra contra os Kayapó, considerados de maneira geral, os inimigos que expulsaram os Kuruaya e Xipaya, a presença não indígena, principalmente dos seringueiros que vieram desbravar a região, não é lembrada como invasão. Pensando nos relatos das pessoas que viveram essa época, aquelas que trazem lembranças de infância ou mesmo as memórias dos pais, existe pouca ênfase nos embates contra os invasores não indígenas; são raramente lembrados dessa forma, apenas em alguns momentos se afirma claramente os abusos dos não indígenas, sejam seringueiros, seringalistas, ou qualquer ordem de patrões que passaram a ocupar essas regiões e a conviver 
juntos com esses indígenas. Acompanhar os interstícios dessas histórias é um movimento para entendimento dos valores envolvidos na dupla-herança que caracteriza os filhos dessas, aparentemente insustentáveis, uniões. A violência contra a mulher é um fator crônico dos abusos perpetrados durante os períodos de ocupação dos territórios indígenas, contudo a ausência de menções diretas é motivada não só pela dificuldade de acesso a esses relatos, se tratando de histórias pessoais de dor e sofrimento, mas também pelo motivo de que a contraparte dessas possíveis uniões forçadas inscreva-se no código das alternativas de sobrevivência abertas. Essa leitura, denotada dos relatos colhidos em campo, não se confunde com a suavização do drama vivido por cada um que passou por processos forçados e traumáticos de mudança e opressão. Bem distante do horizonte de escolhas livres e desimpedidas, as formas e respectivas representações da nova conjugalidade dos Kuruaya e Xipaya são também uma consequência dos conflitos desagregadores, causando repetidos ataques aos costumes originais: são, portanto, uma forma de resistir ativamente, dentre as alternativas de ação que espreitaram esses povos. Outro aspecto desse processo será retomado pelas queixas que se referem às "perdas da tradição", dos lamentos atuais dos mais velhos saudosos, às reivindicações dos mais jovens que hoje se movimentam na direção da valorização de suas heranças indígenas. Pois quando se questiona os motivos da perda ela é tratada enquanto um processo naturalizado pela "mistura com os brancos", e o crescente desinteresse pelas culturas indígenas de pais e avós. Contudo essa mistura não envolve apenas a perda dos costumes, ela produz filhos, que hoje se voltam contra o apagamento da sua origem indígena. Entender os significados e possibilidade dessa afirmação exige da etnografia a persistência em ouvir essas histórias pessoais de encontros que destroem, desencontros que constroem e vice-versa.

\subsubsection{Genealogias Xipaya - Kuruaya}

Um passo atrás do ponto de vista histórico e também para a compreensão lógica dos processos que se passam atualmente entre os interlocutores da pesquisa, situam-se os casamentos interétnicos entre indígenas. Sobre essa condição, prefigura um casamento primordial, por assim dizer, cujo cruzamento mantém-se produzindo um amplo espectro de significados de pertencimento e identificação para seus descendentes, que, por sua vez, desdobram-se muitas vezes nas mais variadas controvérsias entre as famílias indígenas de 
Altamira: a união entre Xipaya e Kuruaya. Essa relação, enquanto fato histórico, remonta ao período em que ambos os grupos estiveram juntos aos não indígenas no conflito contra os Kayapó nas regiões do rio Iriri e Curuá. Dessa forma nasce o estreito vínculo entre os grupos, ou pelo menos, é assim que concebe-se historicamente a ligação entre os dois grupos de origem linguísticas distintas, os Xipaya falando o Tupi da família Juruna, e os Kuruaya falando o Tupi da família Munduruku. Contudo essa mistura que ligou profundamente os dois grupos trouxe diversas consequências que permanecem envolvendo seus descendentes em reconstituições que produzem recriações de heranças e elaborações circunstanciais que estruturam alianças. Contam os irmãos Firmino e Raimunda, filhos de Tereza Kuruaya, uma das matriarcas que foi fundamental para a reconstituição da história do grupo na conquista da atual Terra Indígena Kuruaya no rio Curuá:

"Xipaya foi assim: a índia era Xipaya e o índio era Kuruaya, todo tempo foi junto, todo tempo eles vieram juntos (para a região do rio Baú). Vieram a se separar no (seringal) Bom Futuro. Desse, uma família foi aqui pra baixo, onde chama Kupí, aqui no Xingu já. Foi criando esse grande grupo, nascendo... daí virou Xipaya. Mas sabemos que era o mesmo Kuruaya. Também quando eles chegaram nesse Bom Futuro, ficou uma família pra trás, parece que eram umas dez pessoas mais ou mesmo. Que eles ficaram pra trás num local por nome de Morro Grande. Aí eles voltaram e desceram para o Tapajós, que são os Munduruku. Que era um povo Kurnaya que ficou pra trás, que desceu pro outro rio. A maioria descen no Curuá, e os outros desceram pra lá,",. 


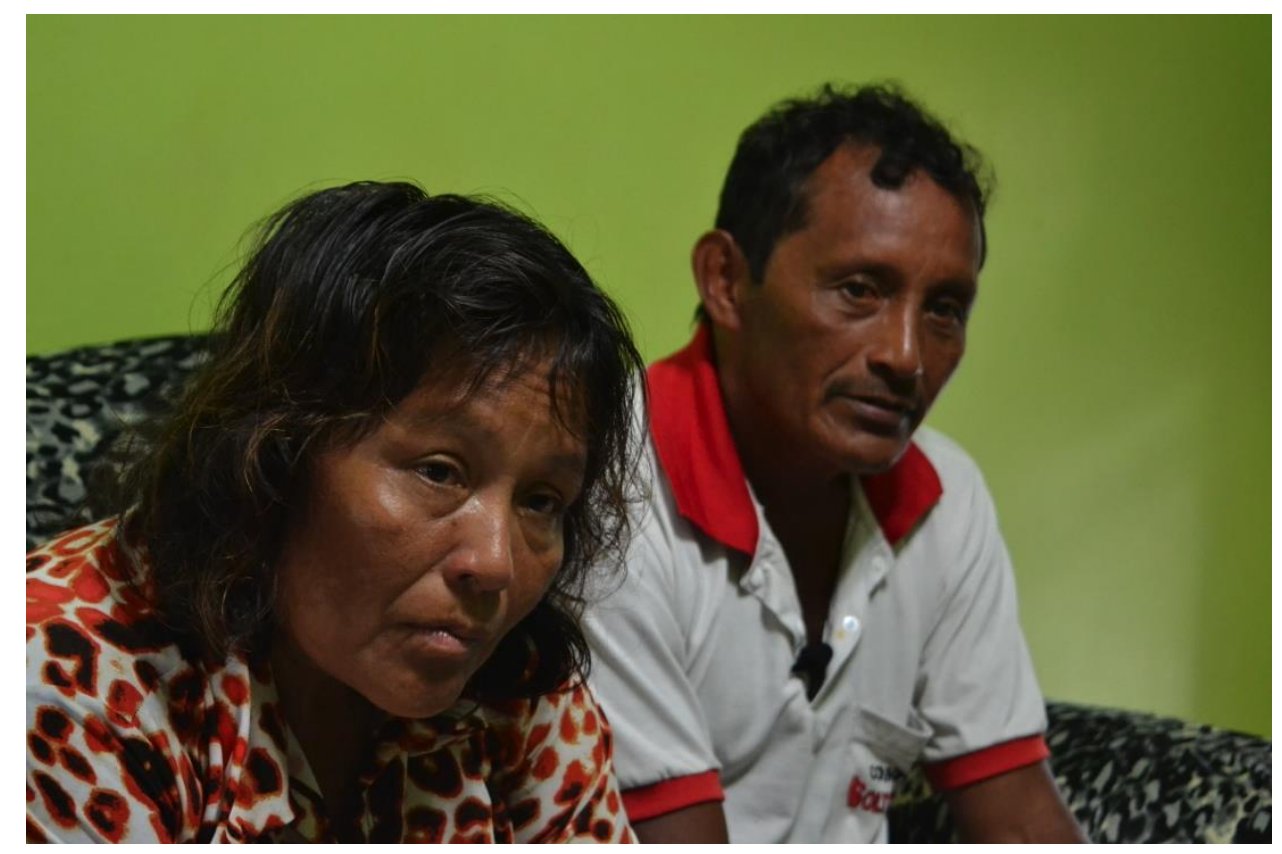

Figura 29 - Raimunda e Firmino Kuruaya, filhos da matriarca Tereza Kuruaya - 2014

A história contada pelos Kuruaya sugere o tema encontrado nas muitas histórias sobre a origem e divisão dos povos. Embora o trecho não possa ser classificado como mito da divisão dos Kuruaya e dos Xipaya ${ }^{59}$ essa descrição faz parte de um conhecimento repassado sobre a natureza da relação entre os grupos. Se observarmos atentamente, nessa relação apresentada por Firmino, os Xipaya aparecem como fornecedores de mulheres aos Kuruaya. Se tomarmos apenas a afirmação, ela situa-se nas controvérsias sobre a origem e a história dos grupos que se confundem com as versões particulares expressas por cada interlocutor, que por outro lado, estão se reportando à heranças familiares que caracterizam esses conhecimentos. Dessa forma, é mais uma vez importante observar outras genealogias para ampliar a compreensão da relação entre Xipaya e Kuruaya:

\footnotetext{
${ }^{59}$ Um dos poucos mitos conhecidos dos Kuruaya, contado por Xipainha, fala da divisão dos Kuruaya e dos Munduruku. Nimuendaju (1948) também registra mitos sobre a divisão Xipaya e Kuruaya (Ver: Capítulo 2 da dissertação).
} 


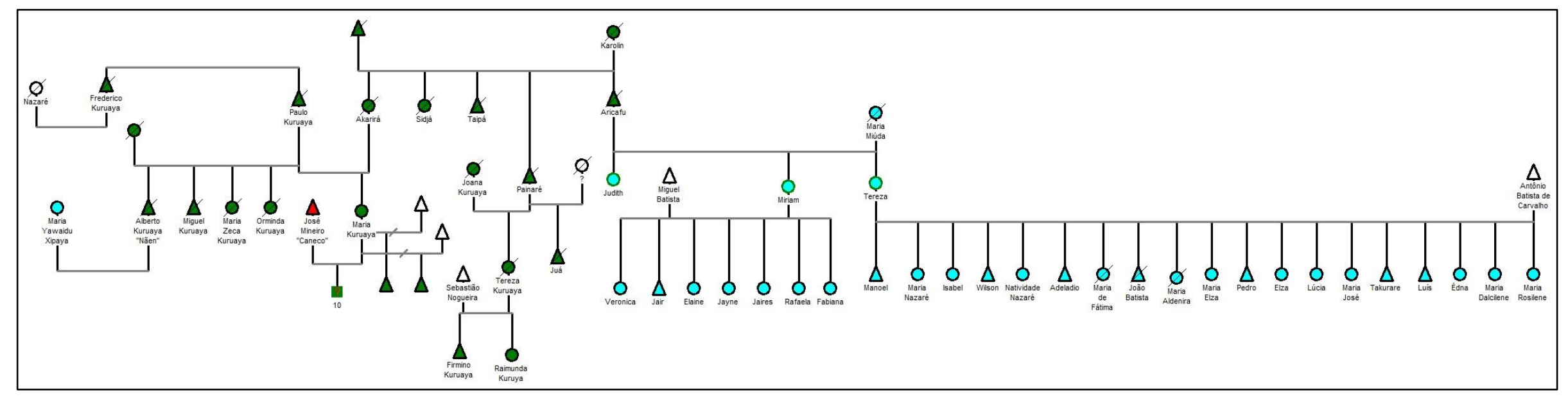

Figura 30 - Genealogia Akarirá, Painaré e Aricafu. 
Dessa genealogia Kuruaya origina-se um grande número de famílias Xipaya e Kuruaya de Altamira. Os três irmãos, Aricafu, Akarirá e Painaré são referências para as gerações posteriores que irão buscar em suas histórias e conhecimentos repassados as origens do povo Kuruaya. Contudo, um aspecto fundamental exposto nas genealogias é a relação entre os Xipaya e Kuruaya, principalmente entre os descendentes de Aricafu. Um possível padrão de casamentos entre um homem Kuruaya e mulher Xipaya não é abarcado pelas genealogias coletadas, contudo acrescenta Firmino que a convivência entre os Xipaya e os Kuruaya remeteria a tempos imemoráveis, quando na verdade poderiam ser confundidos:

“Lá no (igarapé) Pitchatcha, na aldeia Forquilha, que é o nome branco, os Xipaya já moravam juntos lá (com os Kuruaya). Xipaya e Kuruaya andavam juntos. Quando eles foram sair do mato, já vieram juntos, eles andavam juntos era todo tempo. Era misturado, como se fosse o marido e a mulher. Porque assim meu avô era Kuruaya, casado com uma Kuruaya, mas o irmão dele, que chama Aricafu, era casado com uma Xipaya que são avós tudinho desses Xipaya aqui de Altamira, de Elza, esse pessoal todo aí... São parentes desse Aricafu, que é irmão de Painaré, meu avô. Então sim, são parentes nossos legítimos, os Xipaya e os Kuruaya. E vieram a se separar com pouco tempo, não tem vinte anos, que foi um pra um canto, outro pra outro".

Embora Firmino afirme que essa ligação se dava sempre entre a mulher Xipaya e o homem Kuruaya, ressalta que ainda durante os tempos do alto essa estrutura já variava: “ $O$ casamento mais de mulher Xipaya e homem Kuruaya foi no início deles. Eu não vi, mas minha mãe, meu avô contavam. Depois se misturou...". Nessas versões dos interlocutores parece haver uma proeminência Kuruaya, uma vez que a reivindicação é de que os Kuruaya deram origem aos Xipaya, que por sua vez aparecem como fornecedores de esposas, e nunca de maridos. Esse peso dado aos Kuruaya também pode ser observado nas afirmações sobre o modo pelo qual se relacionavam os dois grupos nas festas. Quando questionado sobre qual língua usavam nesses encontros Firmino relata:

"Quando eles se encontravam lá (Nova Olinda) naquela festa eles faziam a bebida dele, que dá o nome de caxiri (...) Muitas das vezes era assim: uns conversavam, outros não (na mesma língua); as vezes um, dois ou três entendiam bem o Xipaya, só que os Xipaya, quase todos eles entendiam bem o Kuruaya”. 
Segundo Tereza Xipaya, que é filha de Raimundo Aricafu Kuruaya e Maria Miúda Xipaya, ambos os pais nasceram ainda na localidade do Baú, lugar que já concentrava também os não indígenas. Embora Tereza Xipaya seja fruto da relação entre os dois grupos não indica qualquer predominância do casamento entre os homens Kuruaya com as mulheres Xipaya:

“O (rio) Baú, era um cidadezinha... (Os Xipaya e Kuruaya) estavam tudo no Baú. Agora tão espalhado por causa dos índios mesmo né; o Kayapó era muito malvado com a gente e a gente não queria estar matando, então afastamos, entregamos o lugar pra eles".

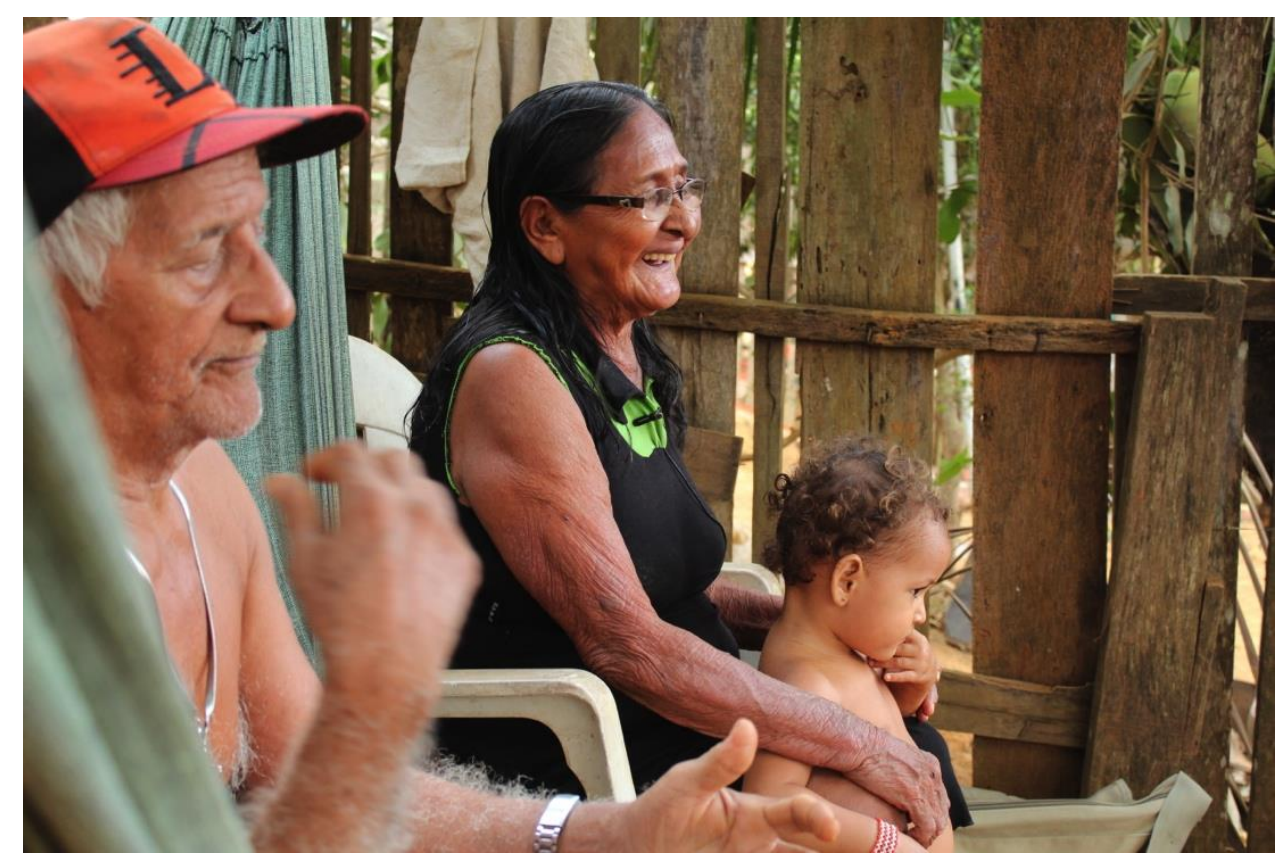

Figura 31 - Tereza Xipaya, matriarca filha do famoso Aricafu Kuruaya, e seu marido Antônio Batista de Carvalho - 2014

A importância Kuruaya no universo indígena citadino pode ser traduzida a partir das referências consagradas pela figura dos antepassados, como foram Painaré, Aricafu, Paulinho Kuruaya, casado com Akarirá, a reconhecida parteira Payá e a mãe de Xipainha e Ana Kurica, Kirinapãe. Assim afirmam tanto Xipainha, Kuruaya de pai Xipaya, como Elza Xipaya também uma importante liderança fundadora da primeira associação indígena citadina de Altamira - que é Xipaya neta do Kuruaya Aricafu, ao relatarem a importância dos conhecimentos de Paulinho e Akarirá quando ambos organizavam o kariá, festa que reunia os Xipaya e Kuruaya no bairro do Muquiço onde moravam. A única filha do casamento de Paulinho e Akarirá ainda hoje reside no bairro do Muquiço, no mesmo local onde moraram 
seus pais quando vieram do alto. Maria Kuruaya expressa a dificuldade em rastrear o momento em que os Xipaya e os Kuruaya formavam dois grupos separados, quando indagada sobre a mistura dos dois acrescenta: "Tudo é Kuruaya. Parece que o pai da minha mãe era Xipaya, mas minha mãe era Kuruaya, mas o pai era Xipaya”. Essa "confusão" foi se processando no caminho até a chegada em Altamira, como aparece nas trajetórias dos mais idosos, como Maria Kuruaya, nascida no seringal Bom Futuro. Assim descreve o nascimento de seus pais:

“Minha mãe nasceu no Curuá, no Baú; meu pai também nasceu no Baú (...). Morava no rio já, fora da aldeia, que minha mãe nunca morou na aldeia, morou sempre no rio, nas ilhas. Nunca foram de aldeia não, nem meu pai nem minha mãe”.

Esse trecho evidencia as mudanças do modo de vida dos Kuruaya, antes conhecidos por serem "povos do centro da mata ${ }^{60 "}$ e após a chegada dos seringueiros e dos Kayapó passaram a viver nas margens dos rios e ilhas (pois "nunca moraram em aldeia" na indicação da interlocutora). Essa transformação permite visualizar como a adaptação necessária influenciará as novas formas de organização observadas na cidade, como a coabitação e convivência dos bairros tradicionalmente indígenas, como a Missão e o Muquiço. Contudo para compreender o que significam as distinções entre os Xipaya e Kuruaya hoje em dia é preciso retomar esses relatos enquanto versões que acentuam e atenuam determinados aspectos das histórias que ligam os dois grupos.

A genealogia de Tereza Xipaya, que é filha de Kuruaya e Xipaya, é um exemplo bastante interessante para pensar sobre a transmissão da "descendência" étnica, reivindicada nos contextos contemporâneos, uma vez que a família é "reconhecidamente"61 Xipaya no cenário da cidade e se constituem no principal ramo a habitar a TI Xipaya no Entre-rios, embora tenham uma importante herança Kuruaya, nunca negada por seus membros, mas sempre relembrada pelos outros Kuruaya nas situações privadas em que surgem as versões históricas. Todas as versões sobre as histórias das famílias se sustentam a partir de encontros, expressos nos casamentos, e cujos significados é necessário perscrutar afim de desvendar como cada peça pode ser localizada nesse emaranhado de relações. Retomando essa

\footnotetext{
${ }^{60}$ Nimuendaju (1948) faz referência ao padrão de habitação Kuruaya, e alguns interlocutores relatam as lembranças dos pais sobre a vida no centro da mata.

${ }^{61}$ Aspas exprimem o consenso sempre polemizado dentro dos círculos restritos de conversas e interpretações.
} 
preocupação, a consideração das famílias Xipaya, começando pela genealogia de Aricafu Kuruaya é um interessante exemplo de como essas identificações são produzidas e os sentidos que retêm para os interlocutores. A análise segue apresentando as genealogias Xipaya de Manuel Bitatá Cojubim, Ducaré Uawmã: 


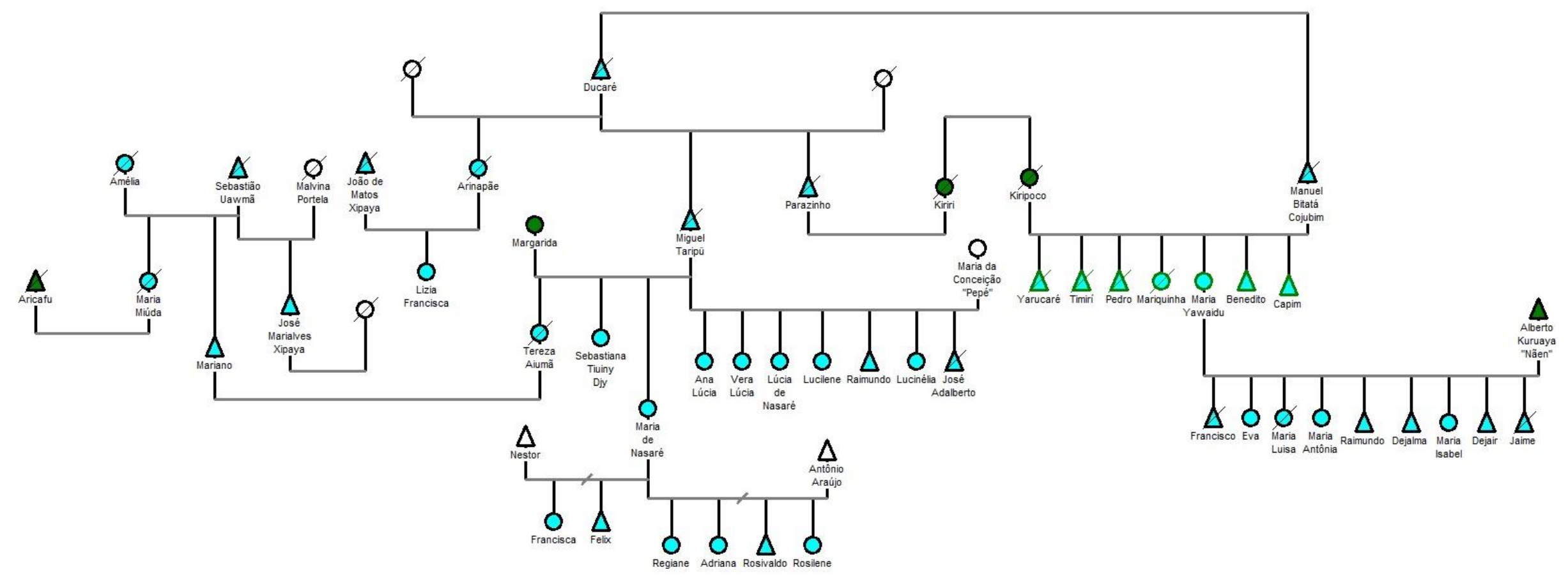

Figura 32 - Genealogia de Manuel Bitatá Cojubim, Ducaré e Uawmã. 
A determinação dos egos para a formação dessa grande genealogia Xipaya é um esforço da pesquisa de juntar as pontas do parentesco entre os interlocutores. Embora as afirmações de parentesco recíproco sejam constantes, nem sempre esses nós são visíveis, e muitas vezes eles não são tão estáveis quanto a ideia de família extensa pode exigir. Portanto, embora seja possível para a etnografia representar uma grande genealogia Xipaya ou Kuruaya, ela é feita também de muitas cisões e linhas de transmissão variáveis, que serão vivificadas apenas nos contextos determinados. Por isso esse parentesco também pode ser produto dos acontecimentos históricos, sobre os quais os interlocutores elaboram no cenário contemporâneo, que mantém múltiplas influências, como foram os próprios estudos ambientais para construção de Belo Monte, ao também elaborarem diagramas genealógicos dessas famílias ${ }^{62}$. Por sua vez, um dos resultados desse complexo de parentesco são as histórias contadas aqui, nas formas das trajetórias individuais, que transportam também os macro-eventos que permearam as histórias desses grupos indígenas. Mantendo a análise cruzada entre os dados genealógicos e as trajetórias podemos ouvir as afirmações de Maria Yawaidu Xipaya, filha de Bitatá e Kiripoco:

"Minha mãe contava, que eles chegaram com medo de Kayapó, eles correram pro Baú. Chegaram no Pitchatcha, daí correram pro Baú, saíram de lá quando eu era pequenininha, daí me trouxeram pra cá, onde eu estou agora. Lá que eu me criei no Cojubim, o nome do pai é Cojubim, ele que botou!’.

A história da família de Maria Yawaidu é também a história do encontro entre Xipaya e Kuruaya. Contudo a relação entre doadores e tomadores se inverte: o pai era Xipaya e a mãe Kuruaya. Casados desde antes do encontro entre os Kuruaya e os Xipaya no rio Baú, como afirma a fala de Maria, a mesma não menciona nada sobre a anterior ligação entre os Xipaya e Kuruaya, ao contrário ressalta as diferenças entre a cultura de seu pai e de sua mãe. A mesma ainda revela que o pai nasceu numa aldeia exclusivamente Xipaya chamada Turupá'tupá, no rio Iriri, supostamente antes da relação entre os dois grupos se intensificar. Descrevendo como foi sua criação, onde hoje é a aldeia Xipaya Cojubim - dentro da TI Arara da Cachoeira Seca - pode-se supor como sua mãe, que era Kuruaya, associou-se aos Xipaya, num processo que parece inverso ao apresentado pelos Kuruaya anteriormente. No entanto é sensível como

\footnotetext{
${ }^{62}$ Essa discussão será feita no próximo capítulo, “A política indígena na cidade de Altamira: desafios antes e durante Belo Monte".
} 
Kiripoco preservou seus costumes, repassando-os aos seus filhos, principalmente Maria, uma das últimas falantes ainda vivas da língua Xipaya e também da Kuruaya. Dessa trajetória familiar em especial é interessante notar o alcance da memória desde antes do encontro no Baú, onde muitos dos interlocutores relataram os nascimentos e os casamentos dos pais e avós. Se evocarmos a contribuição de referências históricas, principalmente de Emilia Snethlage (1910) que visitou a área no ano de 1909, a autora descreve uma situação em que os Xipaya da beira do rio Iriri mantém uma relação mais estreita com os seringueiros, enquanto os Kuruaya se integram nesse espaço apenas com alguns indivíduos, muitas vezes subjugados pelos próprios Xipaya, não representando o deslocamento completo de suas aldeias ainda existentes entre o rio Curuá e Jamanchim. A presença Kuruaya nas beiras do Iriri junto aos Xipaya só se intensificará com a chegada dos Kayapó, e finalmente o enredo da fuga ao rio Baú, tanto dos Kuruaya como dos Xipaya, definindo a ligação com os seringueiros e patrões. Projetando o alcance da história contada por Maria Yawaidu podemos localizar essas oscilações dos encontros entre os Xipaya e os Kuruaya. Assim, o marcador da mistura e da exclusividade são operadores dinâmicos na relação entre os grupos, enquanto uma relação fundada nos casamentos, como exclama a interlocutora: "Ah! E eu casei com Kuruaya de novo, o Nãe era Kuruaya”.

O mesmo ocorre com os Xipaya da família de Ducaré, irmão de Manuel Bitatá. Nazaré, nasceu no seringal Bem Bom, no rio Iriri, é filha de Taripü com a Kuruaya Margarida, e neta de Ducaré, por sua vez casado duas vezes com mulheres não indígenas. Sobre o lugar onde nasceu, descreve:

"Morava muito índio lá também, era (como se fosse) um lotezinho né? Uma maloca, morava muito caboco. Trabalhava pro patrão no seringal. Depois meu pai ficou andando. Parou de tirar leite e castanha e foi só pilotar".

Nazaré não sabe contar em que lugar os pais nasceram e se casaram, no entanto percebemos que a relação de casamento entre esses Xipaya repete a composição discutida anteriormente, homem Xipaya, mulher Kuruaya, assim como o irmão de Taripü, Parazinho foi casado com Kiriri, irmã de Kiripoco, casada com o Xipaya Manuel Bitatá. Após essa união Taripü ainda se casou com outra mulher não indígena, chamada Maria da Conceição, conhecida como Pepé, com quem teve muitos filhos. A própria trajetória de Nazaré, que veio morar no Muquiço com seu pai quando este virou piloto de embarcações que viajavam para o 
rio Iriri e Curuá, já refere-se a condição disseminada do casamento entre os indígenas e não indígenas, gerando filhos com três maridos não indígenas diferentes. Antes de retomar essa condição a partir da percepção dos interlocutores, principalmente as mulheres idosas que hoje são referência para o movimento indígena citadino, a maioria sendo filhas do casamento Xipaya e Kuruaya do alto, cumpre indicar a genealogia de Sebastião Uawmã, outra família Xipaya de Altamira.

Filho de Sebastião Uawmã, José Marialves Xipaya não pôde conhecer o pai pois tinha apenas um ano de idade quando este morreu, deixando sós também sua mãe Malvina Portela, natural de Belém, e sua irmã ainda criança. Marialves não comentou sobre outros casamentos de seu pai, apenas descreveu a história do casamento com sua mãe, quando o pai foi piloto de embarcações onde a mãe era cozinheira. No entanto é indicado por Maria Yawaidu na genealogia de sua família, o casamento de Uawmã com outra índia Xipaya de nome Amélia, possivelmente ainda no alto, do qual nasceu uma filha, chamada Maria Miúda, que por sua vez casou-se com Aricafu Kuruaya, do ramo Xipaya anteriormente apresentado. Nascido em Altamira, Marialves conheceu vários dos "antigos cabocos”, como Aricafu, Taripü, Bibicó, Taripá, Painaré, entre outros, além de ter tido contato com seus tios paternos, Manoelzinho e Tobias Xipaya, o último falecido há pouco tempo com 104 anos. Tobias foi também exímio piloto, assim como seu irmão, tentando convencer Marialves ainda jovem a aprender o ofício, além de contar um pouco sobre a história do pai. Assim, Marialves pôde relatar sobre Sebastião Uawmã:

"Ele nasceu no centro da mata, entre o Curuá e o Mato Grosso, naquela região. Aí depois que eles situaram naquela aldeia Tucamã (atual aldeia na TI Xipaya no rio Iriri) (...) antes do Entre-rios, um quilometro para baixo, e os outros índios que saíram com eles ficaram lá no Cajueiro, dentro do Curuá (onde hoje é a TI Kuruaya). Só que aí botaram, devido ao nome do rio ser Curuá, dividiu duas turmas, então ficou os que vivem no Curuá botaram de Kuruaya”.

No trecho podemos ler o que pode ser indicada como uma versão Xipaya da divisão Xipaya e Kuruaya. Embora Marialves não tenha sido criado pelos pais, viveu ainda jovem com a presença de seus parentes, ouvindo e aprendendo histórias. A explicação da diferença e da mistura entre os Xipaya e Kuruaya é um dos temas explorados quando se lembra dos "cabocos antigos", apresentando-os todos como Xipaya. Segundo o mesmo, eles vieram do 
alto e se juntaram "para cima Missão", nas áreas próximas ao igarapé Panelas, até o momento em que a região passou a ser assedia pelos patrões já em meados da década de 1950. Foi nesse processo também que o Muquiço tornou-se uma alternativa para algumas famílias indígenas, como a de Taripü.

Esse enredo Xipaya-Kuruaya permanece vivo não apenas como casamento comum dos antepassados, mas é material constitutivo para as identificações e reivindicações atuais entre os interlocutores da pesquisa. Uma expressão de como a teia de significados do parentesco Xipaya e Kuruaya relaciona-se com os modos de criação e recriação das identidades indígenas, passa pelos processos de reconquista dos territórios perdidos, com o reconhecimento das Terras Indígenas no Rio Iriri dos Xipaya, e no Curuá dos Kuruaya ${ }^{63}$. A ligação histórica dos grupos, por meio dos casamentos, produziu as versões sobre mistura e precedência expostas acima, sendo que as intersecções propostas tem em geral um caráter extemporâneo, que na verdade condizem com uma lógica de transpor as referências passadas para os esquemas vividos. Mais do que apenas uma leitura a contrapelo de suas próprias histórias, as versões identificam modos de concepção e organização fundantes da experiência desses grupos. Esse operação, que cria, elimina e recria laços de parentesco é um momento fundamental para se compreender a organização política do atual movimento indígena no contexto de Belo Monte, por exemplo. O esforço da etnografia em compreender as múltiplas consequências das controvérsias familiares vai ao sentido de reter as visões e práticas de mundo dos interlocutores nesse processo flagrante de transformações. Enquanto estratégias de sobrevivência, são tentativas de soluções que interferem profundamente sobre a suas vidas. Assim apresentou um interlocutor, sua versão da criação das TIs Kuruaya e Xipaya:

“Quando nós criamos a aldeia Curuá, que hoje é aldeia Curuá, aí veio um bocado de Xipaya pra lá. Vieram esse pessoal do Gilson, a Elza... foram todos pra lá. Só que quando eles chegaram juntos, por eles estarem distantes da gente - Xipaya pra um canto, e Kuruaya pra outro - a gente não se deu, se não ajeitou mais junto como era antes, nossos antepassados... Daí: 'não rapaz, tem um local lá em baixo', na época era João Martim, 'vamos pra lá, que lá não tem ninguém...' Aí, descem... desceram no remo lá, chegaram lá e se apoiaram. Depois de um ano, dois anos, eles começaram a correr atrás também, daí a FUNAI criou a aldeia Xipaya que é lá. Hoje não é João Martins, hoje é aldeia Tucamã”."

\footnotetext{
${ }^{63}$ Outros pontos específicos desse movimento serão apresentados no próximo capítulo.
} 
Perseguindo a matriz de significados contida nos casamentos a análise prossegue abordando como são produzidas algumas percepções sobre a "mistura", recuperando as indicações contidas nas genealogias apresentadas junto das considerações tecidas pelos indígenas.

\subsubsection{A mistura como problema?}

A maior parte dos idosos nascidos ainda nos seringais na região do médio rio Xingu, rio Iriri e Curuá fala da presença não indígena partindo da experiência que tiveram no trabalho de extração do látex. A guerra deflagrada contra os Kayapó, como repetido em outros momentos, tornou essa aproximação fundamental para a sobrevivência dos Xipaya e Kuruaya. Nesse ponto, a percepção de sua própria condição, mesmo nas palavras recentes de seus filhos, ouvidos durante a pesquisa de campo, subentendem a contradição que é a aproximação perigosa com os não indígenas. Firmino Kuruaya explica sobre a criação de sua mãe Tereza Kuruaya:

“Na época quando minha mãe saiu de lá, da aldeia que veio... aí assim, eles pegaram minha mãe e desceram no barco, quando pararam nesse lugar por nome de (seringal) Nova Olinda. Aí que o Seu Antônio Araújo (seringalista) veio, a família dele pegou a mãe para criar. Daí ficaram com a mamãe, que era pra dar a mamãe aqui em Altamira, que nem as outras irmãs dela foram dadas. Aí minha avó, quando eles vinham saindo pro rio, a minha avó estava buchuda de outro bebê, daí ela foi e ganhou bebê. Foi quando os índios começaram atacar onde eles estavam e daí ela pegou, só enterrou o bebê, e veio com a mamãe, que não dava pra carregar os dois. Mamãe contava isso pra gente chorando”.

O trecho apresenta um ponto e seu contraponto, sendo que o sentido contrastante de cada um está intimamente relacionado ao contexto no qual ambos se expressam. O conturbado período referido exigiu da Kuruaya, avó de Firmino e Raimunda, ações drásticas como o infanticídio, na iminência do ataque Kayapó; e como a obrigação de doar seus filhos, frente as dificuldade da criação no ambiente do seringal. Essa "doação" também deve ser questionada, pela relação no mínimo desigual entre indígenas e não indígenas, quando não abertamente violenta nos processos de escravização dos indígenas. Contudo, no retrato atual 
feito por seus netos, a expressão de estranhamento está mais próxima da constatação do infanticídio do que da doação dos filhos, e tal evidência implica justamente na contradição do legado da interação entre os Xipaya e Kuruaya e os seringueiros durante esse período. Conforme é relatado por muitos interlocutores, filhos e netos dos idosos nascidos no alto, a aproximação dos seringueiros e seringalistas era uma processo normal para se proteger dos Kayapó. Tanto que no balanço geral sobre a relação com os seringalistas sempre é pesado o quanto se podia ser um "bom patrão para os índios", no sentido de ensiná-los a trabalhar com a borracha e ajudá-los na proteção contra os Kayapó. Esse peso também advém da comparação com as histórias dos maus patrões, dos contemporâneos a vivência no alto, aos mais antigos, lembrados pelos pais durante o primeiro ciclo da borracha, onde algumas atrocidades eram conhecidas, como o assassinato dos seringueiros depois que entregavam o látex nos regatões por exemplo. Como relata Josa, filha de Payá Kuruaya:

"Falavam, o pessoal antigo que vinha do alto, pra receber dinheiro desse Ernesto Acioly, tinha uma casa ali onde era a caixa d'água, uma casa grande. Aí dizia que o pessoal descia pra pagar, aí dizia que ele não queria pagar o saldo. Aí entrava numa sala, pra fazer o pagamento lá, tinha uma tábua que a pessoa pisava, caia dentro daquele buraco e morria (...) Esse era um patrão antigo que teve aqui... Tinha o Zé Porfírio e o Ernesto... Ah não! O Ernesto era bom, esse Zé Porfírio que era mal. Ele que era mal, que matava as pessoas, não era o Ernesto não. O Ernesto era bom, ajudava muito os índios, ela (a mãe, Payá) falava”.

A vida no alto ficou determinada então pela presença da atividade de extração da seringa, e consequentemente, presença dos seringueiros e seringalistas. Nessa situação todos os Xipaya e Kuruaya foram obrigados a se engajar no trabalho e também com os seringueiros, sendo que o efeito dessa relação foi determinante para os rumos que os grupos tomaram desde então. Nas palavras de Maria Yawaidu:

“Aí eu fiquei lá, cortando seringa até... ai que eu baixei pra cá. O patrão morreu, finado $S$. Antônio Meireles, esse aí que levava mercadoria pro seringueiro. Daí quando ele morreu, e a seringa também se acabou, ninguém queria cortar mais, daí que nós baixamos pra Altamira". 
Maria Yawaidu conta que, quando mudou-se para cidade, já era casada com o Kuruaya Nãe, sendo que os seus sogros, Paulinho Kuruaya e Akarirá, já nessa época residiam em Altamira, no bairro do Muquiço, onde o casal foi morar vizinho. Embora ela ainda tenha se casado com um Kuruaya, nessa época já era bastante comum a união de mulheres Xipaya e Kuruaya com os seringueiros não indígenas no alto, como são exemplos os casos relatados anteriormente de Xipainha e Ana Kurica. Embora o matrimônio interétnico fosse uma constante entre os Xipaya e os Kuruaya, já há algum tempo a prevalência da união com não indígenas vinha tomando forma nos seringais, mas se consolidou decisivamente após a mudança para a cidade de Altamira, e em seu bojo todas as inflexões que a drástica transformação implicou sobre os modos de vida. Nas representações da situação de encontro observadas ainda nos seringais do alto, tem-se uma imagem bastante especifica produzida pelos filhos dessas relações, como conta Firmino Kuruaya sobre o casamento de sua mãe, Tereza Kuruaya, com seu pai, o amazonense Sebastião Nogueira:

"Porque na época quando pai contava, minha mãe falava assim: na época tinha uma grande guerra no Brasil, foi mandado buscar amazonense, cearense, várias pessoas de fora. Na época meu pai tinha uns dezoito anos e veio. Só quando chegou aqui os patrões não deixaram mais eles irem pra guerra, pegou pra cortar seringa, que na época eles chamavam soldado da borracha. Primeiro começou a cortar o caucho no inverno. Daí ele começou a trabalhar com os índios, daí um tio da minha mãe falou de uma sobrinha. Quando foi um dia ele conheceu a mamãe que vivia com os Araújo. Daí como ele era trabalhador no caucho, o velho deixou eles se casarem. Eles se casaram mesmo, nessa época tinha o padre lá”.

Embora o relato seja de segunda-mão, uma vez que fala da encontro dos pais, concentra por isso mesmo certas ênfases que permitem problematizar essa condição da perspectiva de seus efeitos, ou seja, o que dizem aqueles que são filhos desses encontros. Pois, como foi apontado no início do primeiro capítulo, as percepções das idosas indígenas casadas com não indígenas é bastante pragmática, sentido expresso nos termos "amigar e ajuntar", que por sua vez afirmam o modo específico que essa relação é vista. Esse matrimônio poucas vezes é contado como namoro e encontro amoroso, e se a relação descrita parece-nos pouco afetiva nos termos em que estamos acostumados, contudo não é certo afirmar essa ausência. Esse teor não é vislumbrado na história contada por Firmino e podemos deduzir determinadas reflexões em torno dessa descrição, que por sua vez nos permitem situar 
e explorar a condição dos Xipaya e Kuruaya atualmente. Chama atenção o casamento executado pelo padre, pois, embora a Igreja já se fizesse presente nos seringais - realizando batismos e casamentos - não é comum ouvir nos relatos das idosas Xipaya e Kuruaya essa menção, coisa que o termos alternativos para o casamento também denotam. A possível resposta para essa situação pode ser a condição de Tereza, criada desde pequena entre os não indígenas da família Araújo, dos quais recebeu o próprio sobrenome e, como revelou sua filha Raimunda, estimava-os como parentes próximos. Por outro lado, Sebastião Nogueira é apresentado como um seringueiro que, trabalhando com o tio de Tereza, foi qualificado como um bom partido para o casamento com a mesma, que na época encontrava-se entre os doze e quatorze anos de idade. Levando-se em conta a descrição dos interlocutores sobre o casamento dos pais, dois fatos específicos diferem da retórica que instrumentaliza o casamento entre indígena e não indígena durante os tempos do alto: o fato do pai ter aprendido a língua Kuruaya com a mãe e também de ambos terem se mantido casados até a morte: "E meu pai falava bem, meu pai ela ensinou bem. Meu pai falava bem demais! As vezes em casa, só os dois trocando gíria um com outro, eu ficava escutando, mas não pegava de jeito nenhum".

Nesses pontos vemos um desvio narrativo daqueles enredos que apresentam as dificuldades e desigualdades inerentes aos matrimônios entre a mulher Xipaya e Kuruaya e o homem seringueiro, que por sua vez insinuam o ambiente opressivo e mesmo a violência direta em que se encontravam as indígenas. Por outro lado é enunciado pelo filho, que embora ressalte categoricamente sua herança indígena - mesmo porque questionado sobre ela também valoriza a "parte" não indígena - quanto também indagado sobre essa -. Essas questões, produzidas como perguntas sobre a história da vida dos pais, recuperam não apenas eventos específicos que formaram a condição histórica dos grupos Xipaya e Kuruaya, mas também dão acesso, na forma de fragmentos da percepção individual de cada herdeiro, da consistência desses significados de origem ou descendência. Significa que esses grupos atuam há muito tempo num espaço de fronteira ${ }^{64}$, em contextos que obrigaram a transformações que foram da resistência defensiva das mães e avós - como, por exemplo, podemos saborear as

64 O que não denota sua qualificação como "híbridos", "mestiços", ou mesmo "misturados" no caráter indefinível e fluído que o conceito tende a tomar para nossa acepção. Nesse sentido, cumpre destacar que tratam-se de grupos consistentes na composição que tomam, embora se possa descrever os inúmeros processos de transformação porque passaram. 
persistências mantidas na culinária Xipaya e Kuruaya atual -; ao processo afirmativo dos filhos e netos - que retomaram por exemplo a festa do kariá, como expressão da identidade indígena citadina e momento de reunião entre as famílias Xipaya e Kuruaya de Altamira.

Parecendo dispostos em dois polos, tais processos se desenvolvem num tempo e num espaço distintos, entre gerações diferentes, mas cada qual guarda íntima relação. Se o problema para as matriarcas e anciões Xipaya e Kuruaya relacionava-se com as grandes mudança vindas com a aproximação dos brancos, num ambiente em que viam as tradições ensinadas por seus pais serem desvalorizadas, perdidas e achacadas pelos não indígenas, para os filhos e netos, nascidos na cidade ou com um período extenso de criação nesse espaço, o desafio partiu das formas de humilhação por que também passaram nos ambientes urbanos, criando os extremos da negação da ascendência, ao processo de valorização e busca das raízes e recuperação das tradições. Essa composição, cuja direção incide diretamente sobre as novas transformações trazidas com a construção da hidrelétrica ${ }^{65}$, tende a criar novas possibilidades de compreensão e agência dessas pessoas que há tempos aprenderam a movimentar-se contra diversas investidas destrutivas, algumas vezes sem e outras com sucesso.

\subsubsection{Mistura e herança}

Encontrar alguma regularidade para os casamentos recentes nas genealogias Xipaya e Kuruaya é uma proposta complexa, uma vez que a população é bastante grande e sua distribuição espacial na cidade é diversificada. Toda retomada inicialmente alegada da condição urbana dos indígenas de Altamira trouxe a tentativa de explanar alguns fios condutores, como recorrências capazes de encaminhar a discussão seguinte, que visa conceber o corpo atribuído pelos próprios indígenas a essa estrutura sociológica, por assim dizer. Mostrando-se fecundo, ao propor uma explicação genética das formas atuais dos grupos que vivem em Altamira, o tema do casamento interétnico é não apenas uma evidência estatística, mas também material e simbólica, de consequências imprescindíveis para as concepções e práticas entre os interlocutores da pesquisa. Avançando sobre os significados de transmissão e origem vamos ao encontro de sua natureza dupla, inevitável como os dois entes que marcam a relação matrimonial. A forma como os Xipaya e os Kuruaya de hoje retomam suas heranças

\footnotetext{
${ }^{65}$ Nesse momento pode-se observar como todo o caldeirão de acordos e conflitos entre as famílias ecoa nos "espaços para os indígenas" criados devido a construção da usina, e que serão discutidos no Capítulo 4.
} 
diz muito sobre o que está sendo ora promovido, reivindicado e valorizado, ou seja, explicitado, frente ao que antes fora a garantia da reprodução, aceitação, mesmo sobrevivência desses grupos, e hoje parece ser um apêndice na constituição das famílias, e em alguns momentos até mesmo para as consciências individuais. Dito desse modo, parece que hoje o lugar do legado não indígena, ou melhor, seu não-lugar ao qual ela parece estar sendo impelido, conduz ao abandono de suas contribuições para a formação das noções de identidade étnica manejadas no campo político entre os interlocutores da pesquisa. Contudo essa equação, assim como já foi, também hoje não é de simples distribuição. As identificações se processam num ambiente contraditório, que sustenta espaços de valorização de identidades indígenas ao lado dos resquícios do preconceito do dia-a-dia. Nesse contexto, no qual muitos jovens e adultos Xipaya e Kuruaya relatam terem sido discriminados ou ofendidos ${ }^{66}$ por serem indígenas e hoje, por sua vez, são chamados a afirmar-se como indígenas, a observação de cada escolha individual, quando são intercruzadas, permite compreender parte das motivações e circunstâncias para as evidenciações e omissões que constroem as práticas e discursos de autoafirmação étnica e de produção de relações. Se metodologicamente isso pode criar um impasse para a análise antropológica, para a etnografia comprometida com os pontos de vista indígenas sobre a mistura, o recurso inclinou-se como inevitável. Ao relacionarmos os dados numéricos com as histórias dos grupos indígenas de Altamira, contadas a partir de trajetórias pessoais, podemos avançar com um pano de fundo sólido da constituição coletiva dos grupos Xipaya e Kuruaya que, por sua vez, nos permite problematizar genericamente algumas implicações do atual processo de autoafirmação. Segundo Firmino Kuruaya:

"Todo tempo nunca deixou, até hoje tem né. Quer ter um orgulho porque não é indio: 'ah porque não sou índio! fulano de tal é indio!' todo tempo esse negócio; mas todo tempo eu falei e falo: eu tenho orgulho de ser índio. Por que eu tenho orgulho de ser índio? Porque graças a Deus eu sou uma pessoa que trabalha, vivo do meu trabalho. Sempre o índio trabalhou pra ter o que é dele, principalmente esse grupo, o Xipaya e o Kuruaya sempre trabalharam pra ter o que dele. Só hoje tem... devido estar se misturando muito com o branco, daí já vai variando. Gostava de beber, gostava mesmo! Todo índio Kuruaya Xipaya era pé de cachaça! Até mesmo porque eles tinham a produção deles. Na época eles moravam na aldeia e faziam a bebida deles lá”.

\footnotetext{
${ }^{66}$ É interessante notar como a escola na cidade foi muitas vezes lembrada como um lugar onde se sofreu essa discriminação.
} 
O trecho de Firmino refere-se ao contexto do alto, mas é facilmente extensível à situação urbana. A leitura do interlocutor sobre a condição específica dos Xipaya e Kuruaya perpassa pela relação com os não indígenas que foi estabelecida, e também pelos seus perigos inerentes. Sua leitura propõe a comparação de um tempo em que os Xipaya e Kuruaya conquistaram sua posição no sistema social da borracha pelo valor de seu trabalho, com o momento em que essa mistura, transfigurada em dependência, tornou-se um deflagrador de maus hábitos. A bebida alcoólica do não indígena, nesse caso, é signo fundamental para pensar a desorganização e destruição dos indígenas, sendo retomada em comparação ao hábito, qualificado como não prejudicial, de ingestão do próprio caxiri pelos antepassados. Pode-se denotar, nesse bojo, como a disseminação do culto evangélico, e outras consequências, entre os indígenas da cidade acompanha de perto essas situações de vulnerabilidade, em que o alcoolismo também é um fator ${ }^{67}$. Desses signos da relação entre os indígenas e não indígenas retém-se a ideia de como os Xipaya e os Kuruaya foram capazes de se inserir com sucesso no mundo não indígena, como bons trabalhadores, mas sofreram os problemas da "vida do branco" como o alcoolismo. Consequentemente, se a relação dos antepassados com os não indígenas pode ser motivo de orgulho, a avaliação da mistura hoje é contrabalançada pelos hábitos perniciosos. Não que a mistura em si seja considerada prejudicial, uma vez que são também comum situações em que são ressaltadas as qualidades dos Xipaya e Kuruaya como "civilizados"; nos termos nativos, uma capacidade de unir costumes próprios e externos, como muitas vezes é reivindicado na preparação da comida, por exemplo: "nós limpamos e temperamos a caça e o peixe, somos civilizados". A mistura carrega um caráter contraditório, uma vez que é formadora e disruptiva, sendo que ganhos e perdas estão sempre presentes, expressos em narrativas de sofrimento que, por sua vez, costumam valorizar as próprias conquistas.

Nesse campo, as pessoas portadoras de experiência não são apenas referências sobre os costumes e as tradições que resistiram, são também fundamentais para pensar sobre a construção da cultura dos antepassados como um valor e, portanto, falam inevitavelmente sobre noções de mistura. Mantendo ainda um elo com a relação fundante, podem falar sobre os pais e avós como aqueles que tiveram que abandonar o território original e mudar de vida, ao mesmo tempo em que cresceram e se formaram nesse ambiente mutante e, portanto, aprenderam desde muito cedo a "vida não indígena". Seus filhos e netos formam as gerações

\footnotetext{
${ }^{67}$ Embora esses pontos mereçam mais atenção, não é uma proposta da etnografia dar conta desses aspectos da vida social dos indígenas de Altamira.
} 
que passam pelo momento de revisão e reconfiguração dos valores ensinados por seus antepassados, o que os impele à dilemas mais próximos da forma que a categoria de identidade étnica adquire por meio dos dispositivos de legitimação trazidos, por exemplo, por pesquisadores interessados por essa temática que subsidiam órgãos do governo que agora produzem políticas públicas voltadas a esses populações.

A mistura é um marco vital para esses desdobramentos recentes, quer seja sobre os efeitos da "perda cultural", que oferece inúmeros exemplos de como a relação desigual e destrutiva do contato trouxe sequelas impossíveis de esquecer, quer proporcione a esses grupos proximidades físicas e culturais com o "mundo não indígena", permitindo acessos para sua luta por direitos sociais. As consequências da perda dos costumes tradicionais até hoje infletem sobre os sentimentos e anseios pessoais de cada interlocutor, como se pode observar nas diversas manifestações de arrependimento com relação ao fato de terem perdido a “oportunidade” de aprender a língua indígena; segundo Tereza Xipaya:

"Não aprendi de burra que eu fui! Lá onde eu morava tinha muito branco né, daí naquilo de brincar com os outros, esquece, como eu esqueci de falar..."

Esquecimento e desinteresse são auto-cobranças porque passam hoje muitos idosos e adultos Xipaya e Kuruaya ao lembrarem que os pais eram fluentes na língua original, ao mesmo tempo em que podemos confirmar como a consolidação da habitação no ambiente urbano foi um fator predatório com relação ao abandono dos velhos costumes. Maria Kuruaya viveu praticamente por toda sua vida na cidade e também lamenta não ter aprendido a língua. No entanto é curioso notar como os outros filhos de Akarirá, como o marido de Maria Yawaidu, o Kuruaya Nãe, já tiveram a oportunidade de aprender a língua Kuruaya. Assim conta Maria Kuruaya:

“Nunca, nunca aprendi! Ela (a mãe, Akarirá) só falava em português (comigo). Minha mãe sabia, ela cortava gíria com a Maria (Yawaidu, cunhada), moravam juntas elas duas, tudo numa casa só, na mesma rua, mas cada qual com sua casa. E ela cortava gíria com a Maria e eu nem nunca aprendia". 
A língua, nos termos postos pelo cenário atual, é identificada como um marcador significativo sobre a origem, e sempre lembrada como uma perda inestimável. Contudo muitas expressões dessa perda carregam as transformações por que passaram esses grupos, denotando as diversas estratégias necessárias que obrigavam aos Xipaya e Kuruaya transformarem todos seus hábitos e costumes. Em certo sentido, a relação íntima com os novos vizinhos não indígenas, que se tornavam muitas vezes parentes, parecia uma tendência natural, defendida e demonstrada pelos filhos e netos dessas relações. Essa situação alterava os valores presentes na esfera privada e familiar; assim como fala Raimunda Kuruaya:

"Eu não aprendi (a língua) porque foi falta de interesse meu mesmo. Porque quase ninguém se dedicou... A gente não tinha quase assim... a pessoa que ensinasse, daí foi acabando".

O impacto do desaparecimento da língua original, desencadeado pelo contato com o não indígena, hoje é geralmente lamentado, mas as afirmações anteriores sugerem como esse também foi um processo dinâmico. Embora a reconstituição histórica completa desse processo seja de difícil alcance, as leituras feitas pelos idosos sobre essa situação fornecem alguns fatores objetivos eleitos para exposição de uma determinada subjetividade gestada no contexto em que se encontravam, auge do contato com os não indígenas com suas transformações consequentes. As palavras de Maria Yawaidu revelam esses conteúdos:

"A filha desse Marcos Ciro que ensinou a gente. Nós falávamos tudo na gíria mesmo. Daí eu disse pra mamãe, até ela chorou... Quando nós ficamos tudo grandinha já, nós pedimos pra ela: 'mamãe nós vamos entregar essa continha pra senhora, nós vamos tirar, nós vamos pintar nossa unha, nós não queremos mais jenipapo pra pintar não, preto ninguém quer mais!' Dai eu tirei meu brinco, que ela fazia bonito... Entreguei pra ela e ela começou a chorar: 'agora vai acabar!' ela disse: 'vai acabar do caboco que vai contar história...' Eu digo: 'deixa acabar, não quero mais!' ai agora eu penso... (risos). Agora eu penso, tem dia... Ela dizia, que depois de muitos anos eu ia pensar. Eu disse pra ela que eu não ia me arrepender né? 'Mas vai minha filha', bem que ela dizia'.

Trazido por quem hoje é uma referência máxima para preservação das línguas tanto Xipaya como Kuruaya, o trecho traz um tipo diferente de lamentação sobre as perdas advindas do contato com os não indígenas. Em primeiro lugar fala de um ambiente 
certamente diferente daquele encontrado na maior parte dos outros enunciados sobre a vida no alto, que ressaltam a fuga e abrigo junto aos seringueiros não indígenas. Nesse aspecto Maria exclama como achavam estranho o dito branco, Ciro, vivendo entre os cabocos de sua família, onde atualmente é a aldeia Cojubim. Esse contexto permite compreender a manutenção da língua entre esses Xipaya e Kuruaya. Mas o que chama atenção, nas sutis diferenças desse enunciado, é o modo como a perda está expressa, pondo em evidência a tensão intergeracional da filha ativamente abandonando os costumes tradicionais mantidos pela mãe, que se vê incapaz diante dessa crise. Embora se trate de um drama pessoal e familiar, o conteúdo expresso no enunciado traz um exemplo não apenas extensível para outros casos, mas principalmente indica o sentido geral das questões que tomaram de assalto os grupos familiares Xipaya e Kuruaya. Esse sentido geral foi construído a partir dessas situações de crise em que as soluções possíveis, tomadas em relação às mudanças inerentes que se processaram, se dispuseram num plano de idas e vindas: explicitações e elipses, depreciações e valorizações, estratégias de sobrevivência e agência, que hoje são revistas, redefinidas e repensadas para a criação de novas práticas e discursos, como são os de autoafirmação por exemplo. Esses caminhos, difíceis de definir a priori, extrapolam as formas instrumentalistas e reducionistas de se pensar as condições da "retomada" Xipaya e Kuruaya em Altamira, que tendem a ser limitadas por nossos dispositivos de reconhecimento étnico, como é a própria noção de "auto-reconhecimento". A consideração efetiva dessas nuances, pela etnografia, permite experimentar reflexões densas sobre os modos possíveis de problematização sobre identificações, aqui pensadas enquanto vivificações das heranças que afetam os corpos e mentes dos interlocutores da pesquisa, ao lado das traduções que produzem formas instrumentalizáveis, como são as categorias de identidades étnicas, mas que nem por isso deixam de manter efeitos contundentes sobre a vida social indígena, seja influenciando e transformando ou sendo apropriadas e exauridas pelos indígenas. Ao comunicar um evento particular, entre ela e sua mãe, Maria Yawaidu nada mais faz do que revelar um pouco das possibilidades desse enlace, um complexo emaranhado que a etnografia tenta restituir, também comunicando ao seu modo.

\subsubsection{Mistura na comida}

Se as genealogias nos servem para explorar muitos dos significados do parentesco entre os Xipaya e Kuruaya de Altamira, dando acesso ao emaranhado de nomes e conexões 
entre as famílias moradoras da cidade, e assim permitindo explorar como os interlocutores compreendem e expressam suas relações entre si, essas, por outro lado, só mantém um valor decisivo porque estão lastreadas a práticas de parentesco, capazes de fazer e reiterar os laços necessários à consistência das relações entre parentes. Assim, as genealogias, e os respectivos valores nativos aos quais elas correspondem, falam de princípios de coesão e pertencimento que também precisam ser elaborados e consubstanciados, completando a memória afetiva que conecta os sujeitos atuais com os antepassados, ao reforçar as ligações hodiernas.

Os afetos, correspondentes à constituição das preferências culinárias entre os interlocutores da pesquisa, preservam um espaço onde as famílias Xipaya e Kuruaya da cidade podem desfrutar da comida que gostam. Essa comida é antes de tudo uma ligação com os antepassados, traz as lembranças das avós e principalmente das mães que conseguiram transmitir suas receitas e técnicas culinárias como o principal legado da tradição Xipaya e Kuruaya que foi obrigada a adaptar-se às adversidades conforme caminhava ao encontro da civilização não indígena, perdendo outros costumes:

“Quando nós morávamos lá no alto, a gente sempre vinha passear aqui, meu padrasto era branco né. Dai ele vinha aqui, deixava a gente em Altamira, e ia pra Belém de barco. Ai nós ficamos aqui, na casa da minha madrinha, Miloca o nome dela. A mamãe ia pra lá né (para o Muquiço, onde os índios moravam) eu queria ir, mas minha madrinha não deixava, dizia: 'Não vai não! Você vai querer falar só na língua dos índios, e eu não quero que você fale!' (risos). Meu padrasto também não queria que eu falasse não, mas eu falava! Aí eu não ia, outras vezes eu fugia e ia. Eu gostava porque lá fazia mingau com peixe, também tinha macaco assado, porcão, a cabeça da anta, pra gente comer assada, eu gostava de ir... gostava não, gosto! Eu não como hoje porque não tem mesmo. Daí naquele tempo era bom, na casa da tia Akarirá, da tia Payá, tinha o Pombo, com o pessoal dele... O Tobias, o Taripü... Todo mundo falava na língua (...). Era dessa maneira aí... Ai foi indo, foi indo... quando eu vim pra cá mesmo (Altamira), já não era mais menina, já era mãe de dois filhos. Foi em 1954, eu acho que foi. Bem antes da Transamazônica. Ficamos numa casa de um homem que tinha por nome Chico Milhão. Meu marido foi trabalhar na Ilha da Fazenda. Eu estava gestante da menina, daí, quando foi pra eu ganhar, ele mandou eu vim embora pra cá, pra Altamira". 
O trecho do relato de Xipainha, sobre suas lembranças de Altamira quando ainda era menina e nem morava na cidade, é expressivo de como a "mistura com os brancos" implicava a dificuldade em manter o idioma nativo, conforme foi discutido anteriormente, mas traz também a memória de como nesses encontros com os antigos Xipaya e Kuruaya da cidade a comensalidade era um momento fundamental de confraternização que se mantém vivo nas preferências alimentares da interlocutora. Diferente da língua, da qual se tem hoje um grande desafio de preservação e revitalização, os hábitos alimentares persistem na forma dessas asserções sobre o desejo da comida boa. O lugar dos "cabocos" na cidade é antes de tudo um espaço de reunião, sugerindo a ideia de um local cerimonial, em que a conversa e a comensalidade desfrutavam de valor ritual provavelmente rememorado das antigas aldeias perdidas do alto. Xipainha ressalta o prazer de, mesmo ainda sendo criança, frequentar esses encontros com sua mãe, onde podia comer a comida de sua preferência, localizando nesse passado recente a forma encontrada pelos Xipaya e Kuruaya de reiterar na cidade, os laços criados pelo encontro entre os povos ainda nos rios Iriri e Curuá, e seus afluentes. Essa localização pretérita, assim como vista em outros discursos sobre as tradições e os bons hábitos, também alerta sobre as perdas inevitáveis, mas diverge desse quadro de exclusiva lamentação para a exclamação que exalta a manutenção da preferência alimentar, pois, se o costume pode se perder, a vontade e o desejo são o espírito categórico que não cessa de animar o gosto pela comida boa. Compreender os sentidos da perda expressada é fundamental como forma experimentar a culinária nos termos propostos pelos interlocutores, como podemos observar no relato de Tereza Xipaya:

"Das outras comidas eu não alembro mais não... Quando eu fiquei grande, que comecei a me entender, nunca falaram nesse negócio não (comida tradicional). Lá era muito índio, mas tinha muito branco né. Aquilo você sabe, o branco vai conversando aqui e ali e a gente vai perdendo até o jeito da gente falar. Isso que nós perdemos muita coisas assim... Tem muita mulher índia que sabe, mas nós... tinha muita gente branco, e naquilo ali esquece (...) Mamãe cansou de falar: 'aprende a fazer essas coisas'; 'Ah mãe deixa isso pra lá, depois eu vou' (risos) Nunca mais... é por isso aí que eu não sei né. A perdição foi minha mesmo”.

Os lamentos mais uma vez falam das perdas oriundas do contato com os não indígenas e são expressivos de como a adaptação foi um processo turbulento e que impingiu aos Xipaya e Kuruaya uma série de mudanças, acima de tudo rompendo com a transmissão de modos de 
fazer (costumes e hábitos repassados), como as receitas da mãe, que Tereza queixa-se de não ter aprendido. Esses esquecimentos da interlocutora - de como a comida era feita e novamente lembrando a perda do idioma - denotam a intensidade afetiva dessas privações, em que as perdas materiais traduzem o quadro emotivo da desolação que aflige os filhos e netos que não se importavam com as tradições dos pais e avós. Embora esse quadro corresponda, em determinado grau, com perdas objetivas, como a língua em desuso que hoje se torna moribunda de falantes fluentes, os hábitos alimentares revelam sua distinção, pois fazem parte de uma memória reconstituível e que por isso é viva:

"Mamãe fazia tudo: fazia beiju, fazia massa de bolo... Alembro demais, vixi! Ela gostava de fazer um peixe, uma carne de anta, ou então veado, ou então mutum, tudo isso ela fazia e era gostoso. Botava leite de castanha também, aquilo era gostoso. Tinha o ralinho de ralar castanha, ai pegava, quebrava a castanha e ia ralar. Ai aquilo tirava, coava o leite da castanha na peneira. Papai fazia a peneira, sabia fazer a peneirinha, desse tamanhinho assim, pra coar o leite da castanha (...). Na cidade ela fazia o peixe, às vezes ela assava que tinha o forno, botava pra assar. Quando não... Era carne, ela botava pra assar, que o índio gosta mais de seco que de panela, de caldo né. Então tudo ela fazia na cidade, tinha um fogãozinho".

As recordações das comidas preparadas pela mãe de Tereza são mais um índice de como a mistura é pensada entre os Xipaya e Kuruaya de Altamira. Se a mistura trouxe o problema dos esquecimentos, por outro lado ela não pôde destituir as pessoas da memória visual, olfativa e gustativa que informam o paladar Xipaya e Kuruaya. Nesse sentido, as alusões não se dispõem apenas como lembranças, são também reminiscências, valores obstinados pelas cozinheiras das casas de Altamira. Se cada receita vai falar do encontro com os não indígenas, que também implicaram novos ingredientes como os temperos inseridos no cardápio diário, a diversidade prevalente é aquela da cozinha indígena. A despeito dessa incorporação, é saliente como persistem as iguarias servidas pelas matriarcas, do simples beiju até os requintados caldo de cari ou jabuti no leite de castanha, apreciados principalmente aos finais de semana nos lares da cidade. Perseguindo essas produções no universo gastronômico da cidade encontramos os maridos seringueiros absorvendo boa parte das sugestões de suas mulheres cozinheiras, que sabiamente faziam as pequenas concessões, construindo sutilmente os desejos de filhos e netos: 
“Naquele tempo o pessoal não plantava o arroz. Era muito difícil a gente ver o arroz, mas aí era mais a farinha, comia todo tempo na farinha. Demorou muito pra acostumar a comer com arroz (...). Agora que eu acostumei com o velho, que ele gosta mais de caldinho, larguei mais de comer esse negócio de assado, é muito difícil eu comer (...). Agora eu como com o arroz: boto o arroz, depois boto a farinha, boto um pouquinho de caldo, mas não muito, pra molhar o arroz, pronto".

Os maridos vão aos poucos adquirindo também as habilidades como caçadores nessa nova configuração da família Xipaya e Kuruaya, embora muitas idosas descrevam as caçadas que empreendiam quando eram jovens. A vida nos seringais era também a vida na mata, como muitas vezes rememoram as interlocutoras, e ainda que a maloca antiga seja apenas uma referência dos mais velhos que já foram, os núcleos nos seringais são lembrados como aldeias, pela quantidade de indígenas que viviam com os recém-migrantes. Por isso a caça persistiu durante muito tempo como base da alimentação e hoje é motivo para reunião da família e celebração entre os interlocutores da pesquisa. Algumas delas se tornaram mais raras no contexto citadino, como a anta, o macaco, o veado; e outras são tão disseminadas que já se torna difícil inclusive perseguir sua indiscutível origem indígena na cidade, como o jabuti, o tracajá, o porcão, entre outras. Todas as matriarcas cozinheiras ainda se referem às receitas de caça propondo que as preferências se mantém atentas à lembrança cerimonial do gosto pela cabeça e pelo cérebro, como destaca Raimunda Kuruaya:

"Nós comíamos também muito macaco com leite de castanha. Come toda a carne, mas a cabeça que é mais gostosa, o miolinho dele! O macaco você pega, limpa e corta ele todinho. Tem que tirar o couro, nós tiramos o couro primeiro, na faca. Pendura ele e depois puxa o couro dele que ele sai todo. Ai você corta ele todinho e você vai escaldar ele, bem escaldadinho; com limão, vai temperar ele, e deixa ele refogar bem; põe na água e deixa ele cozinhar. Quando ele está bem querendo amolecer, você deixa secar um pouco da água, aí você coloca o leite de castanha e vai mexendo pro leite não coalhar. Aí até quando ele cozinhar, aquela calda fica bem grossa. Faz um pirãozinho escaldado de farinha... aí ó! (risos) (...). Quebra a cabecinha dele, o miolo é bem gostoso! Tira os olhos dela, os dentes, a língua, deixa bem limpinho... Nós fazemos assim né, mas os outros índios não, eles comem até com o couro. Eles dizem que não tiram o couro, os Kayapó, porque dizem que onde está a gordura do macaco é no couro dele, ai faz só rapar. A mãozinha dele é gordinha... (risos). 
Sempre os Kuruaya tinham, tipo assim, mais cuidado com as comidas deles, eram mais civilizado né. Desde quando eles moravam junto, a farinha deles era bem feita, tudo deles era organizado, faziam roupa... tudo era organizado."

A influência não indígena na culinária não é negada pelos interlocutores mesmo que a relação desigual pareça se inverter nesse caso. Portanto se hoje o arroz com feijão está amplamente integrado ao dia-a-dia das famílias indígenas da cidade essa absorção está mais alinhada com a capacidade desses grupos de se relacionarem com os "cristãos", como sendo povos que sempre mantiveram seus próprios costumes "civilizados" como ressalta Raimunda, do que ao sentido da resignação como uma leitura apressada dos lamentos pode levar a entender. Os novos ingredientes apenas aprimoram as receitas, mais servindo à boa comida do que a transformando, como reitera Ana Kurica:

"No tempo a gente assava bem aí, no quintal, fazia um moquém, bota um tijolo e põe pra assar. Tira o coro põe sal assa e come. Agora na mata não, na mata é outra coisa né Xipaia? (...) Aqui na cidade é dificil a gente fazer, porque não tem o que tinha no mato né? A gente come carne de gado, a galinha, o peixe... Quando os indios podiam trazer carne de caça a gente tinha como fazer nosso tipo de comida. Agora não traz mais nada que o IBAMA proibiu tudo! Quando chega um pedacinho de porcão, os brancos caem em cima, quando eu sei, já era. Bem aqui nessa rua tinha um homem que quando trazia era muito, trazia uma caixa de isopor cheinha de queixada, mas não chegava... Quando eu sabia, mais ela aqui, né Xipaya? Já tinham comprado tudo, nem sobrava (...). Porco de casa? Deus que me livre! Não dá pra fazer não! Se tivesse porcão aqui, a gente podia assar uma parte, o resto a gente cozinhava no leite da castanha, como era de costume. Ai ficava gostoso né? Com todo tempero do branco já, é bem gostoso. Muita pimenta do reino, alho... Aqui no meio do branco tudo é temperado, lá na aldeia não, só era sal”."

A comida boa pode ser preparada na cidade mas outras dificuldades são impostas pelas novas adversidades como as proibições da caça e sua comercialização. Contudo esse mercado ainda é bastante difundido na cidade, mantido tanto pelos indígenas aldeados como pelos habitantes da área rural que trazem as carnes para venda. Nesse cenário as estratégias se renovam sendo preciso ceder o espaço da comida diária aos produtos de fora, como carne de 
gado e frango, e industrializadas como macarrão, embutidos, entro outros, mas também se destaca a posição do peixe nesses cardápios, por sua facilidade de comercialização na cidade. Mesmo assim o costume de consumo de caça é mantido, exprimindo a forte simbologia da comensalidade para os indígenas da cidade, que por outro lado exige a elaboração de determinados alimentos que preenchem vínculos de afinidades e pertencimentos:

"Eu sempre... assim, quando eu morava ali né, eu encomendava e as pessoas traziam, mas agora não, está mais difícil por causa da proibição sabe? (...) Aqui é assim: eu comprei um pedaço de porco do mato, foi oito reais o quilo. Chega lá na vizinha detrás e eu compro. Agora o jabuti eles querem vinte, vinte cinco. A paca é cinquenta reais, daquela pequena, da maior é cem reais (...). Porque o branco é assim, hoje é sábado vamos almoçar numa churrascaria'. E a gente se for comer uma comida cozida, assada, uma paca, é a mesma coisa que dissesse que o cara foi pra churrascaria. Você está comendo aquilo que você tinha, dos seus antepassados. É muito mais gostoso do que comer numa churrascaria!’”.

As "reconstituições" observadas nos relatos também dão grande destaque às receitas que usam os pescados, valor que, por sua vez, está intimamente ligado ao modos de ocupação que os Xipaya e Kuruaya mantiveram desde quando vieram do alto e foram morar nas beiras do rio Xingu e igarapés da cidade. Essa combinação entre a memória afetiva dos parentes que já foram, a manutenção das preferências alimentares, e a opção pela moradia nas áreas próximas ao rio, constituem num complexo que cria sentidos bastante próprios das experiências indígenas em Altamira. Toda essa mistura acompanha as trajetórias que envolvem deslocamentos físicos e simbólicos, ao tratarem também de transformações dos modos de organização das famílias. Esse, é claro, refere-se a incorporação dos entes não indígenas, que por sua vez serão transformados, basta lembrar que a maioria dos migrantes de origem nordestina casados com mulheres indígenas também teve que se adaptar a um ambiente e modo de vida bastante diferente do experimentado em seus locais de origem, seja no tempo da borracha ou durante a implantação da rodovia Transamazônica. Muitos deles então se tornaram pescadores, seja para completar o sustento da família, ou mesmo como atividade comercial principal, embora seja comum ouvir a preferência desses migrantes pela atividade agropecuária. Isso posto, as mulheres indígenas estenderam sua importância desde o preparo até mesmo a coleta do peixe, como exemplifica Miriã Xipaya, irmã de Tereza Xipaya, sobre o aprendizado com o pai, Aricafu Kuruaya: 
"Eu cansei de acompanhar ele na canoinha né, com o arco e eu atrás. Ele fazia um cigarrinho de folha, ai jogava debaixo do pé da planta. Ai o peixe vinha pra pegar a folha e ele 'tan', flechava. Ele flechava mais é o tucunaré, o trairão, o pacu branco, o pacu que come sarão... que são duas qualidades de pacu. Fora o de seringa, o de seringa é do fundo, só pega ele com anzol, com uma chumbada muito grande, só aí que ele agarra. Porque ele come muita seringa, no tempo da seringa, é ele que está de baixo, pegando as frutas. Pra lá (Cachoeira do Jericoá, na Volta Grande do Xingu) eu pesco muito”.

Os saberes Xipaya e Kuruaya que envolvem os costumes culinários ainda mantêm determinados tabus alimentares que são localmente interpretados pelo sistema de "reima". A expressão caracteriza os alimentos que podem ser prejudiciais à saúde sob determinadas condições de quem os ingere. Trata-se se de um sistema de classificação dos alimentos que denota a profunda intersecção entre as influências indígenas e migrantes nessa região, como o uso da categoria "reimoso" pelos interlocutores aventada:

"Mulher parida não pode comer curimatá, surubim, peixe de couro, o que for peixe de couro mulher não pode comer. Agora o pacu, a pescada, o tucunaré, esses peixes a mulher pode comer, quando está de resguardo. Quando a mulher está naqueles dias, com sangue, ela não pode comer... Nesses dias ela não pode fazer nada, nem lavar roupa não pode, não pode nem suspender uma roupa um peso qualquer. Ela fica sentada, ou vai se deitar. Passa o dia só dentro de casa mesmo, sem fazer nada. Faz de conta que está de resguardo (...). Reimoso de caça é caititu, paca, tatu, jabuti, a anta... só o que pode a mulher comer é o veado de chifre liso, de chifre encourado não come. O que não é reimoso é o jabuti branco, agora jabuti vermelho, vixi Maria, Deus me livre! Uma vez eu estava de resguardo, estava com bem era uns quatro dias. Esse velho (marido) matou um jabuti pra eles comerem né. E esse jabuti estava cheirando, eu disse: 'O meu Deus, não posso comer um jabuti desse'. Fui e trisquei, um pedacinho, desse tamanhinho, foi nada. Mas passei mal, quase morri, andei perto! Ele perguntando o que era, não quis dizer pra ele né. Até quando foi e eu disse, 'comi um pedacinho de jabuti...' 'Mas mulher o que é isso? Isso é venenoso!' Ai fui obrigada a tomar purgante pra fazer aquele arrasto todinho. Hoje não, hoje em dia está diferente né? A mulher bebe, faz bagunça, quando vê, está doente! Não sabe de que, mas foi extravagância que fez”. 
O sistema de classificação baseado na reima expresso por Tereza Xipaya é, contudo, bastante variável conforme seu enunciador, sendo que parece ser uma combinação não apenas das influências não indígenas e indígenas, mas expõem as contribuições particulares de cada grupo, que nos casos alentados referem-se a composição Kuruaya e Xipaya, característica de Altamira. Sobre essas sutis distinções, também se enquadram no horizonte dos conhecimentos e práticas resguardados por cada família indígena da cidade, compondo também o cenário das manifestações simbólicas que refletem a organização indígena urbana. Significa dizer que cada diferença veiculada pelos interlocutores, que apresentam tais sistemas de técnicas e conhecimentos, se inscrevem também, tal como é com as versões sobre as histórias, nas novas cisões e dissidências que marcam as diferenças atuais entre os Xipaya e Kuruaya:

"Peixe de couro o Kuruaya não gosta muito não, pirarara, surubim, Kuruaya não gosta não. Nós gostamos de escama, nós temos cisma com esses outros. Piranha come, mas não é tanto assim, porque é reimoso. O peixe que é bom de assar, na palha da banana é pescada, curimatá, ariduia, a matrinchã (...). Não come capivara também, de jeito nenhum, tem cisma. Usa reimoso para falar só no português né, Kuruaya não fala assim (...)”.

Essas ligeiras diferenças nos modos de conceber os tabus alimentares também se estendem às distinções que serão encontradas nas receitas apresentadas pelos interlocutores da pesquisa. Um caso emblemático é o mingau de banana comprida verde com peixe. Dividida entre os Kuruaya, que preferem o pacu branco, e os Xipaya que dizem que o melhor peixe para o prato é o trairão, essa receita parece transbordar os limites do circuito das famílias indígenas de Altamira, sendo apreciada pelos vizinhos não indígenas, como descreve Ana Kurica:

“Também faço, mantchareá também... Já partiu pro caldo do peixe né. A gente descasca banana verde, bem descascadinha. Tem que ser bem verdinha, porque se for meio amarelada não presta, fica doce. O peixe, separa a carne todinha e põe numa vasilha, ai fica só o caldo. O melhor peixe pra fazer é o pacu... Pacu de seringa não presta não pra fazer, tem que ser o pacu branco. Dali a gente vai e bota a massa da banana e vai mexendo... Wáruê, (mexer) na língua Kuruaya. Ai está com todos os temperos. Todo mundo gosta do meu mantchareá aqui nessa redondeza! Os netos gostam, aqui minha vizinhança gosta, é assim. Faz do mesmo jeito que eu fazia junto com a mamãe. Porque lá na aldeia não tem tempero, só é a banana e a água... Só o caldo do peixe. Agora aqui na cidade, a gente põe o tempero que põe na comida 
do branco: é a cebola, é o tomate, pimentinha cheirosa, pimentão, cheiro verde... Aqui no meio dos brancos. Ai come com a carne do peixe e a farinha. Mantchareá é só no almoço. Aqui a minha vizinha ela pergunta: 'quando é que vai fazer mantchareá?' Ela é branca mesmo, mas vixi Maria ela gosta é muito!”

A exclamação de Ana Kurica sobre o gosto de sua vizinha pelo mantchareá é uma alusão sintomática de como as fronteiras das experiências indígenas em Altamira são reposicionadas a partir tanto de valores de parentesco como de convivência e coabitação. $\mathrm{O}$ mantchareá é talvez um dos pratos Xipaya e Kuruaya mais significativos por levar sua marca propriamente indígena por todos os lugares onde passa, sendo porta voz da riqueza culinária desses grupos e também um nome que transcende os circuitos exclusivos das famílias, exprimindo toda contribuição desses grupos para a cultura local. É também sugestivo o fato de ser um prato essencialmente baseado na mistura da banana e do peixe, sua resistência representando também os caminhos percorridos por essas culturas indígenas até chegarem ao ponto atual em que lutam pela valorização de suas contribuições no contexto local, recriando e fortalecendo seus rituais de comensalidade sob novas perspectivas, como por exemplo as oficinas de culinária promovidas pelas associações da cidade ${ }^{68}$. São nesses novos espaços, que rearticulam conhecimentos ancestrais, onde podemos observar as idas e vindas da experiência indígena na cidade, como também alude Miriã Xipaya sobre as heranças de sua mãe, mesmo tendo convivido com ela apenas durante uma parte da infância:

"A minha mãe fazia e eu gostava né, e eu fiquei com aquilo e eu faço a comida que ela me dava né (...). A ova do peixe que ela botava com farinha, botava na vasilha, amassava, deixava crescer e fazia os bolos. Essa comida que eu gosto até hoje... Mas meus filhos não gostam não, mas eu faço e gosto. Os netos que eu criei gostam”.

Aos percalços intergeracionais característicos da tensão que percorre a manutenção das tradições ancestrais entre os indígenas da cidade de Altamira somam-se às adversidades que mais um vez tentam solapar os modos de vida desses grupos tão criativos em reinventar sua condição. A comida boa é mais um ingrediente das culturas indígenas da cidade

${ }^{68}$ Sobre esse aspecto o Capítulo 4 abordará os processos de "fortalecimento cultural" encampados pelo movimento indígena citadino. 
ameaçado por entraves externos, por mais que o talento dessas pessoas para descobrir novos caminhos a partir dos escombros impostos seja mais do que comprovado. A alimentação fala acima de tudo de valores de parentesco e de convivência; fala sobre comer bem, ficar satisfeito em dividir e feliz por perseverar; em síntese, fala sobre como viver bem:

“Assim eu vejo dizer, não sei se é verdade: diz que quando essa barragem varar lá em baixo, ai disseram que vão passar cinco anos sem pegar nenhuma escama de peixe! Será que isso é verdade? Assim o pessoal está falando... Cinco anos! Ai digo: 'aí meu pai do céu, pelo amor de Deus que eu gosto demais de peixe!' Se fosse pela minha vontade não trazia peixe nenhum... Peixe estranho? Eu pelo menos não gosto, de jeito nenhum. Tem que ser pacu, curimatã, trairão, piau, tucunaré, pescada..."

\subsubsection{Casamento é mistura? Sentidos do casamento indígena-não indígena}

A interconexão entre as experiências Xipaya e Kuruaya na cidade, que falam de persistências e mudanças do ponto de vista dos interlocutores, faz retomar mais uma vez a importância do que foi traduzido como casamento interétnico, é tratado muitas vezes pelos interlocutores pelo termo amigar ou ajuntar, e que a etnografia generalizou como o matrimonio fundamental para na formação histórica e social dos grupos indígenas de Altamira. A tentativa foi de deslocar-se entre a estrutura e conteúdo do matrimônio, seus aspectos formais e afetivos, que revelam um pouco da composição sociológica e cultural dos Xipaya e Kuruaya de Altamira. Após cruzar a evidência estatística do casamento indígenanão indígena, resta finalmente concluir com alguns apontamentos sobre a interconexão entre o casamento interétnico, as noções de mistura e a valorização da origem indígena na construção de novas estratégias de sobrevivência que são, no limite, orientadas pela busca por viver bem. Nesse sentido é importante retomar o modo como os interlocutores percebem e lidam com o matrimônio, na expressão de Maria Kuruaya sobre seus casamentos:

“Eu era moça, saí gestante do rapaz, aí fiquei buchuda em casa. Pois é, esse rapaz queria casar comigo, mas eu não quis né, peguei um nojo, depois que eu saí gestante do menino, não quis mais ele de jeito nenhum, nem a voz dele eu queria mais escuta. Dai ele falou pro papai: 'eu não vou obrigar casar com ela a força, ela não me quer. Eu quero casar com ela, mas ela não me quer, que eu posso fazer?'. Ele falou pro papai. Nem sair pra falar com ele eu quis, 
fiquei lá dentro, ouvindo a palavra dele... Ele era cristão puro mesmo. Depois me ajuntei com o pai da minha menina, da Rosinha, passei cinco meses com ele, ele era do Maranhão também, dai fiquei gestante e ele foi embora. Ai tinha esse casalzinho, papai que criou os dois; pescava, vendia, trazia boia pra gente comer. E eu também trabalhava e ajudava também ele, era assim”.

No excerto Maria Kuruaya apresenta os seus dois relacionamentos com os pais de seus dois primeiros filhos, sendo ambos não indígenas. O enredo das "tentativas" de casamento se agrega às narrativas de Ana Kurica e Maria Xipaya, que abriram o presente item, acrescentando mais elementos à defesa da importância feminina na recomposição dos grupos Xipaya e Kuruaya da cidade. Em suas apresentações da trajetória de vida é possível verificar a recorrência de mais de um casamento, e muitas vezes também a gestação de filhos "fora" do casamento. Esse panorama pode ser identificado como um dos efeitos do contato, presumindo a transformação das regras de casamento encontradas entre os Xipaya e Kuruaya antes dos períodos de fuga e dispersão para a cidade de Altamira. Contudo, essa transformação fundamental na organização da vida coletiva do grupo parece ser abordada de forma indireta, também porque já longínqua para os interlocutores, expressando-se ora com naturalidade sobre a difusão dos casamentos com não indígenas, mas também por vezes revelando percepções e sentimentos de estranhamento, sugerindo dificuldades de relacionamento, ou mesmo aludindo a conflitos exacerbados nesses matrimônios. A descrição a seguir aparece novamente como contraponto, ao falar do casamento de Maria Kuruaya com o Kayapó Caneco, a partir de esquemas a primeira vista bastante próximos do universo urbano no qual ele está inserido:

"Ah, quando eu conheci Seu Caneco, ele morava bem aí na casa de Seu Alberto, que morava na casa do Milico. Dai ele vinha lá de baixo né, a cunhada dele morava aqui também, aí eu conheci ele, nós morávamos ali na Barriguda ainda. Ai eu conheci ele, ele também me conheceu, falou que queria morar comigo, ai o pai também queria: 'né minha filha, aproveita que acho que ele é um bom rapaz trabalhador, pesca, acho que de fome tu não morre não'. Dai eu digo, vou experimentar, se eu me der bem eu moro com ele, se não eu largo. Pois é, dai eu fiquei com ele, depois nós casamos, e pronto, eu tive esses filhos com ele até hoje”. 
Trata-se da descrição de um encontro, cujas referências caracterizam bem o espaço em formação da cidade: o deslocamento da beira do rio para a cidade; a presença nos bairros ainda em formação; a persistência das relações com os patrões da borracha e do gato; e a atividade de pesca como sustento da família na cidade. Vemos no exemplo, que a mesma valorização do homem trabalhador é ressaltada, assim como foi feito na descrição de casamento de Tereza Kuruaya com o seringueiro Sebastião Nogueira, pais de Firmino e Raimunda. Contudo, em ambas as descrições o pertencimento étnico - um é Kayapó, outro é não indígena amazonense - não é colocado diretamente como questão para o casamento, embora se possa inferir para cada caso como esse fator pode ser relevante, mesmo quando relevado. Se Firmino, como filho desse casamento entre indígena e não indígena, ressalta sua ascendência indígena, Raimunda, sua irmã, declara sobre o casamento de Maria Kuruaya, que é filha de sua tia avó Akarirá:

“Já o Caneco, ele é Kayapó, eles são bem chegado mesmo. A família deles parece tudinho, mesmo os netinhos deles, mesmo cabelo do índio (...) e o índio mesmo, a mesma característica, no rosto você conhece, a pessoa que você nunca viu, você conhece que é indio".

Esse critério, a princípio essencialista e aparentemente contraditório, pois a própria Raimunda é filha de "caboca com cristão", só pode ser compreendido num contexto maior, que localiza as noções de pureza para os grupos da cidade, e remonta às suas transformações ao longo do tempo. Como foi desenvolvido e defendido, a mistura é um objeto dinâmico no qual as perdas e ganhos postas pelas relações são avaliadas de variadas formas. É nesse quadro que se situam as afirmações de Raimunda, correlacionando diferenças temporais, territoriais e familiares, ao conjunto das circunstâncias que afetaram os Xipaya e Kuruaya, assim como ela própria:

"Porque eu não tive só um marido não! Índio ele não costuma viver só com uma pessoa. Ele vive ainda bem, só que depois... Acho que tem que ser índio com índio né? Mas quando não é, não dá certo. Foi o tempo que eu vim pra cá e fiquei solteira sabe? Só andava pras festas... Daí me juntei de novo e fui embora pra aldeia. Aí meu marido era muito bravo, valente, daí o pessoal não aceitou ele lá (aldeia Curuá, TI Kuruaya). Daí voltamos, foi quando meu pai vendeu lá pra Socorro (a casa), dai saímos de lá (bairro do Muquiço)”. 
$\mathrm{Na}$ afirmação fala-se da conjuntura na qual o casamento entre indígena e não indígena é tomado ao mesmo tempo como comum e problemático. O próprio enunciado é construído num jogo de respostas e indagações que denotam o modo como essas relações de casamento se constituíram ao longo do tempo. Para essas Xipaya e Kuruaya vivendo na cidade, embora não se possa mais restituir as formas da aliança anteriores ao contato, sendo o próprio casamento com não indígena a alternativa natural, ela ainda mantém perigos que correspondem a reprodução do grupo, o que no ambiente não indígena e urbano significa, de modo grosseiro, a manutenção da "indianidade". Esse deslocamento, que por sua vez está intimamente relacionado a todas as "influências externas" que correspondem a vida na cidade e em meio aos não indígenas, é a consequência da reconstrução das alternativas de sobrevivência, o que no limite expressa a vontade de viver bem, ou seja, de acordo com o valores próprios, seja vivendo com vizinhos conhecidos ou comendo a comida que se gosta, por exemplo.

O casamento interétnico não nos oferece nem uma solução de equilíbrio entre influências, quando apostamos no equacionamento da dupla herança paterna e materna, resolvida em categorias como mestiço, caboclo e tantas outras, e nem um caminho sem volta do contato, em que a faceta da destruição, tão pesada sobre esses grupos, conduziu-os ao esvaziamento completo ou aniquilação (embora essa seja a história de grupos indígenas da região que foram extintos). Ainda assim ficamos tentados ao meio termo, falando da mistura como algo acabado e final, "são povos misturados". Se pureza e mistura são qualificados o tempo todo não existe uma mistura que seja mais ou menos misturada do que outra, e nem uma pureza que nunca foi maculada, embora essas condições possam ser questionadas e reavaliadas dentro do universo de valores produzidos pelos indígenas e não indígenas. Contudo se acompanharmos essa disputa - porque se trata de uma modo de valorizar heranças ou reivindicar mudanças - observamos sua característica essencialmente mutável, que ora obriga certos aspectos a serem escondidos com vergonha, e ora permite que eles sejam expostos com orgulho, por exemplo. Por isso que o casamento de indígena com não indígena pode hoje aparecer como problema quando se reivindica a indianidade no espaço privado e familiar, ao mesmo tempo que também não é, porque se assume com orgulho a herança indígena nas demonstrações públicas. E isso se dá de forma muito semelhante ao fato de que mesmo sabendo-se herdeiros dos Xipaya e Kuruaya, se possa afirmar categoricamente para os outros que se é Xipaya ou Kuruaya, e não haveria nenhum problema em inverter as categorias 
étnicas e as instâncias que as acionam nas duas afirmações, embora o contexto seja determinante não apenas seu entendimento, como também é condição para as perspectivas que dão sustentabilidade para esses deslocamentos. O que está posto em questão são perspectivas de ação que lidam com os eventos objetivos como processos contínuos de formação.

Um exemplo paradigmático, e também bastante anedótico, das elaborações sobre as possibilidades do parentesco foi presenciado após um intercâmbio cultural entre os Juruna de Altamira (da cidade e aldeias da Volta Grande do Xingu) e os Yudjá do Parque indígena do Xingu, cujo objetivo era o "resgate da cultura", como dizem os interlocutores ${ }^{69}$. Em meio aos diversos anseios do encontro com os parentes distanciados, alguns jovens meninos Juruna estavam muito interessados, obviamente, em paquerar as jovens Yudjá, muitos deles já pensando no casamento como um meio de se retornar às "raízes originais" e aprender a língua. Em certo momento, questionando as adolescentes Juruna sobre a mesma paquera com os jovens Yudjá, essas ressaltaram categoricamente que não seria "bom negócio casar-se com índio e ir viver na sua aldeia!”. A afirmação se explicava pela percepção das mulheres Juruna sobre o regime de trabalho excessivo das mulheres Yudjá, e foi completada pela revelação de uma já adulta Juruna, filha de uma importante liderança Juruna da Volta Grande com um mulher não indígena, de que sua mãe a orientou claramente que não seria bom ela se casar com os Xikrin que visitavam sua casa quando ainda era jovem, porque se, caso o fizesse, passaria a vida vivendo para o trabalho!

Pode-se afirmar que existe hoje uma busca dos grupos Kuruaya, Juruna, Xipaya e Arara pelas referências de "indianidade perdidas" durante os processos históricos pelos quais passaram. Esse movimento, por contraditório que pareça, ecoa atualmente através dos dispositivos de mitigação de impactos que foram trazidos com o advento da construção da hidrelétrica de Belo Monte, pelos quais os grupos da cidade disputaram espaços de reconhecimento enquanto indígenas, que no limite falam de propostas políticas que articulam novas experiências. O próximo capítulo pretende percorrer alguns desses espaços políticos dos indígenas de Altamira, voltando aos tradicionais bairros do Muquiço e da Missão, atuais São Sebastião e Jardim Independente, que serão em parte alagados pelo reservatório da usina.

\footnotetext{
${ }^{69}$ Um dos efeitos da presença de Belo Monte, os projetos sobre patrimônio cultural serão pensados no próximo capítulo também como "atores" nessas redes ameríndias da cidade de Altamira.
} 
Embora hoje a presença de Belo Monte tenha uma amplitude incomensurável na transformação da paisagem e das relações, a etnografia mantem-se atenta em como as alianças familiares, as novas lideranças indígenas citadinas, e a criação de associações indígenas recorrendo secundariamente também aos movimentos de retomada das terras indígenas preenchem o campo de atuação política das experiências Xipaya e Kuruaya de Altamira. 


\section{A POLÍTICA INDÍGENA NA CIDADA DE ALTAMIRA: DESAFIOS ANTES E DURANTE BELO MONTE}

\subsection{Movimento indígena citadino e os projetos hidrelétricos}

Durante uma conversa com Gilson Kuruaya, liderança indígena da cidade, já em meio ao pico de construção da hidrelétrica de Belo Monte, o mesmo argumentou que o movimento indígena de Altamira nasceu inicialmente com as lutas autônomas de cada etnia pelo direito à terra e só conseguiu ganhar alguma unificação após a primeira tentativa de barramento para geração de energia elétrica no rio Xingu, no final da década de 1980, o conhecido Projeto Kararaô. Mesmo que a liderança fosse apenas uma criança quando toda a situação ocorria na região é notável como refere-se ao fato como fundante da experiência unificadora do movimento indígena do Médio Xingu. Esse episódio também foi considerado uma grande escola para outras lideranças da cidade, que puderam acompanhar alguns grandes nomes indígenas que encaparam a resistência contra a barragem nessa época, como Raoni, Marcos Terena, Ailton Krenak e Paulinho Payakã por exemplo, todos presentes no $1^{\circ}$ Encontro dos Povos Indígenas do Xingu em Altamira, realizado no ano de 1989. O encontro ficou famoso pelo episódio em que a Kayapó Tuíra encostou o facão no rosto do então presidente da Eletronorte, José Antônio Muniz Lopes, que anunciou, após o episódio, que as usinas hidrelétricas na Amazônia não teriam mais nomes indígenas. A dimensão desse fato, e da vitória então conquistada que impediu que a barragem fosse construída naquele momento e fez a luta ganhar inclusive repercussão internacional, foi um pré-indicativo de como esse grande empreendimento, com todas suas expectativas, passaria a afetar em diversos níveis toda essa região. O primeiro efeito evidenciado, da ainda prevista hidrelétrica, sobre a organização política indígena, conjugava-se justamente com o momento da constituinte democrática no país. Nesse contexto o projeto da barragem se configurava como um deflagrador para um novo horizonte de mobilização política entre os indígenas da região, seja por meio dos dispositivos estatais que passavam a operar com a garantia do direito constitucional de proteção aos povos indígenas e com os acordos internacionais os quais o país passava a ser signatário, mas também com a formação de novas instâncias de articulação no cenário político entre os movimentos indígena e ambientalista, que permitiram, em grande medida, a visibilidade das lideranças indígenas, como no encontro supracitado, e resultaram em um marco no socioambientalismo brasileiro. Pode-se creditar a todo esse movimento de 
resistência contra a construção da barragem a revisão do projeto de Kararaô, que alterado passaria a se chamar Belo Monte. Durante os anos da década de 1990 o projeto foi remodelado, sendo que o reservatório da usina, por exemplo, foi reduzido de $1.225 \mathrm{~km}^{2}$ para $400 \mathrm{~km}^{2}$, evitando a inundação da Área Indígena Paquiçamba na Volta Grande do rio Xingu, e também diminuindo as áreas alagadas dentro do perímetro urbano de Altamira. Durante esse período não foi consumada nenhuma movimentação efetiva para construção da obra. Apenas no início da década de 2000 que o projeto Belo Monte é retomado com perspectiva de implementação, devido em grande medida à situação energética do país no momento que ficou conhecido como "apagão". No ano de 2011 inicia-se a construção da barragem, que perdura até o presente momento (2015), já em estágio avançado. A seguir, uma breve cronologia do projeto (ISA, 2015):

\section{CRONOLOGIA DE BELO MONTE}

1975: Iniciados os Estudos de Inventário Hidrelétrico da Bacia Hidrográfica do Rio Xingu.

1980: A Eletronorte começa a fazer estudos de viabilidade técnica e econômica do chamado Complexo Hidrelétrico de Altamira, formado pelas usinas de Babaquara e Kararaô. Essas usinas representariam o alagamento de mais de 18 mil $\mathrm{km}^{2}$ e atingiriam sete mil índios, de 12 Terras Indígenas, além dos grupos isolados da região.

1986 - Concluído o Plano 2010 - Plano Nacional de Energia Elétrica 1987/2010. Os estudos do Plano indicam Kararaô como a melhor opção para iniciar a integração das usinas do Rio Xingu ao Sistema Interligado Brasileiro. Até então, os estudos de Babaquara eram a prioridade.

1988 - Paulinho Paikan, líder Kayapó, Kube-I Kayapó e o etnobiólogo Darrel Posey, do Museu Emílio Goeldi do Pará, participam, em janeiro, na Universidade da Flórida, em Miami (EUA), de um simpósio sobre manejo adequado de florestas tropicais. Ali, relatam indignados que o Banco Mundial (BIRD) iria financiar um projeto de hidrelétricas no Xingu que inundaria sete milhões de hectares e desalojaria 13 grupos indígenas. Apesar de serem diretamente atingidos, os índios não tinham sido consultados. Foram convidados a repetir o relato em Washington.

1989: Realizado o $1^{\circ}$ Encontro dos Povos Indígenas do Xingu, em fevereiro, em Altamira (PA), com o objetivo de protestar contra as decisões tomadas na Amazônia sem a participação dos indígenas e contra a construção do Complexo Hidrelétrico do Xingu. 
1994: O projeto é remodelado para tentar agradar ambientalistas e investidores. Uma das mudanças preserva a Área Indígena Paquiçamba de inundação. O reservatório da usina, por exemplo, é reduzido de $1.225 \mathrm{~km} 2$ para $400 \mathrm{~km} 2$

2000 - O Plano Plurianual de 2000-2003, nomeado Avança Brasil, contempla Belo Monte não apenas como uma obra estratégica para elevar a oferta de energia do país, mas também como um projeto estruturante do Eixo de Desenvolvimento - Madeira/Amazonas. A Fundação de Amparo e Desenvolvimento de Pesquisas (Fadesp), vinculada à Universidade Federal do Pará (UFPA), é contratada para elaborar os Estudos de Impacto Ambiental (EIA) do Complexo Hidrelétrico de Belo Monte

2001: Divulgado um plano de emergência de US\$ 30 bilhões para elevar a oferta de energia no país, o que inclui a construção de quinze usinas hidrelétricas, entre elas, Belo Monte. A Justiça Federal determina a suspensão dos Estudos de Impacto Ambiental (EIA) da usina. A obra deve ser licenciada pelo Instituto Brasileiro do Meio Ambiente e dos Recursos Naturais Renováveis (Ibama) e não pelo governo do Pará, já que o Xingu é um rio da União; e os EIA devem examinar toda a Bacia do Xingu e não apenas uma parte dela.

2002: Contratada uma consultoria para definir a forma de venda do projeto de Belo Monte. O presidente Fernando Henrique Cardoso critica ambientalistas e diz que a oposição à construção de usinas hidrelétricas atrapalha o País. O candidato à presidência Luiz Inácio Lula da Silva lança um documento intitulado "O Lugar da Amazônia no Desenvolvimento do Brasil", que cita Belo Monte e diz que "a matriz energética brasileira, que se apoia basicamente na hidroeletricidade, com mega-obras de represamento de rios, tem afetado a Bacia Amazônica". É realizado o $1^{\circ}$ Encontro dos Povos Indígenas da Região da Volta Grande do Rio Xingu, em maio, que reúne cerca de 250 representantes da sociedade civil e povos indígenas, para reafirmar posição contrária à construção de Belo Monte.

2003: O governo federal anuncia que vai retomar os estudos de impacto ambiental para a construção da hidrelétrica de Belo Monte, no Rio Xingu, obedecendo às recomendações do Ibama e do Ministério do Meio Ambiente.

2006: O processo de análise do empreendimento é suspenso e impede que os estudos sobre os impactos ambientais da hidrelétrica prossigam até que os índios afetados pela obra fossem ouvidos pelo Congresso Nacional.

2007: Durante o encontro "Xingu para Sempre", indígenas entram em confronto com o responsável pelos estudos ambientais da hidrelétrica, Paulo Fernando Rezende, que recebe um corte no braço. Após o evento, o movimento elabora e divulga a "Carta Xingu Vivo para Sempre", que especifica as ameaças ao Rio Xingu e apresenta um projeto de desenvolvimento para a região e exige sua implementação pelas autoridades públicas. O Tribunal Regional Federal da $1^{\text {a }}$ Região, de Brasília, 
autoriza a participação das empreiteiras Camargo Corrêa, Odebrecht e Andrade Gutierrez nos estudos de impacto ambiental da usina.

2009: A Justiça Federal suspende licenciamento e determina novas audiências para Belo Monte, conforme pedido do Ministério Público. Em outubro a FUNAI libera a construção de Belo Monte, e em ofício ao Ibama considera o empreendimento "viável, observadas as condicionantes", embora reconheça que o EIA/Rima de Belo Monte não dimensionou corretamente todos os impactos e tampouco apresentou propostas concretas de como evitar ou diminuir aqueles esperados sobre os povos indígenas da região. Representantes de povos indígenas, ribeirinhos, extrativistas, ONGs, agricultores e movimentos sociais analisam os impactos da construção de Belo Monte e produzem parecer próprio sobre o projeto, durante o II Encontro dos Povos da Volta Grande do Rio Xingu, na Vila da Ressaca.

2010: A licença prévia é publicada em $1^{\circ}$ de fevereiro. O leilão é realizado em 20 de abril, sendo vencedor o Consórcio Norte Energia S/A, com lance de R \$77,00 por MWh. Em 26 de agosto é assinado o contrato de concessão.

2011: Em 26 de janeiro, o IBAMA concede à Norte Energia uma licença válida por 360 dias para a construção da infraestrutura que antecede a construção da usina. Em 18 de fevereiro é assinado o contrato das obras civis. Em $1^{\circ}$ de junho o IBAMA concede a licença de instalação. No mês de outubro, movimentos sociais e indígenas realizam um novo encontro em Altamira e ocupam, por um dia, o maior canteiro de obras da usina, o Sitio Belo Monte.

2012: No mês de fevereiro o Consórcio Norte Energia, responsável pela usina hidrelétrica Belo Monte, é multado em R 7 milhões pelo Ibama, por atraso na implementação do Projeto Básico Ambiental da obra. No dia 14 de Junho, indígenas, agricultores e pescadores afetados pela construção da Hidrelétrica de Belo Monte, ocupam o local onde a barragem da usina será construída, próximo à vila de Santo Antônio. Após dois dias de negociações entre os índios e a Norte Energia, no dia 11 de Julho os índios desocuparam o local. No início do mês de outubro as obras no canteiro Sítio Pimental são paralisadas devido ocupação de indígenas e representantes de movimentos sociais. Os representantes afirmam que a ocupação é devido o descumprimento dos acordos firmados com a Norte Energia depois da ocupação que ocorreu entre junho e julho.

2013: Em março um grupo de índios e ribeirinhos ocupa um canteiro de obras de Belo Monte, paralisando a construção. Em maio, um grupo de 180 índios Munduruku invade um dos canteiros de Belo Monte e paralisa a obra. Em agosto, cerca de 200 moradores do entorno das obras da usina hidrelétrica de Belo Monte, em Altamira (PA), bloqueiam de madrugada o acesso a um dos canteiros de obra para pedir energia elétrica em suas casas. Em outubro, o Tribunal Regional Federal da $1^{\text {a }}$ Região, em Brasília, ordena que as obras da hidrelétrica Belo Monte, no Pará, sejam interrompidas por 
ilegalidade no licenciamento. Dois dias depois, a decisão foi suspensa por liminar. Em dezembro FUNAI emite ofício convocando a Norte Energia a consultar os indígenas da cidade sobre o novo assentamento urbano.

2014: Estatal chinesa e Eletrobras vencem leilão para operação de Belo Monte por R \$ 434 mi. Avaliação inédita dos impactos sobre os índios, realizada pelo Instituto Socioambiental - ISA revela inadimplência em $80 \%$ das ações. Em fevereiro, ocorre reunião entre indígenas, presidente da FUNAI e representantes do governo federal e da Norte Energia em Altamira, sobre a execução do Plano Básico Ambiental do Componente Indígena (PBA-CI). Em maio, indígenas da Volta Grande do Xingu bloqueiam entrada do canteiro de Belo Monte para exigir condicionantes socioambientais. Em novembro, audiência pública convocada pelo Ministério Público Federal, denuncia que famílias ribeirinhas irão perder suas casas e estão fora do cadastro de compensações.

2015: Aneel nega pedido para prorrogar entrega de Belo Monte. Punida pela agência reguladora, concessionária responsável pela obra terá de comprar energia para repor o volume que deveria estar produzindo no começo do ano. Indígenas ocupam a sede do IBAMA em Altamira, o protesto acontece depois que representantes da instituição faltaram a uma reunião convocada para discutir problemas em condicionantes socioambientais da usina. Em junho ISA publica dossiê "Belo Monte - Não há condições para a Licença de Operação". Em setembro, FUNAI e IBAMA emitem parecer contra a emissão da licença de operação alegando a não execução de condicionantes.

$$
* * *
$$

Se por um lado a não construção da hidrelétrica pareceu durante algum tempo um uma vitória definitiva para o movimento indígena e socioambientalista, por outro seu espectro manteve-se sempre presente nas conversas e nas apreensões dos moradores da região de Altamira. Não era incomum ouvir durante os períodos de permanência na região de Altamira a exclamação de muitos que viveram durante anos sob a ansiedade de uma profecia que nunca parecia se cumprir. Alguns episódios anedóticos, como a permanência de profissionais da área energética que mantinham-se na região desde os primeiros estudos nos anos de 1970, até outros mais dramáticos como um colono que havia vendido suas terras ainda durante a primeira tentativa de barramento nos anos 80 e vivia esperando a chegada da usina até então, revelam alguns extremos das experiências pessoais que esse grande empreendimento manterá mobilizando até sua efetivação. Em suma, a usina de Belo Monte representou até sua chegada, e para toda a região, um grande estado de expectativas, sejam positivas ou negativas. Para aqueles que simpatizavam com sua chegada, é interessante observar, em geral 
expressavam como a região havia sido abandonada pelo desenvolvimento econômico desde a construção da rodovia Transamazônica, o que traduz de maneira bastante paradigmática como se dá a relação de ocupação e exploração histórica dessa região. Por outra parte aqueles que temiam sua implantação preocupavam-se não apenas com os desastres ambientais, mas sempre ressentiam-se pela inevitável transformação de seus modos de vida, seu "sossego" que não voltaria mais, como diziam. As duas visões estereotípicas, embora contraditórias, não eram mutuamente excludentes nos relatos ouvidos, mesmo que mantinham-se pressupondo a defesa de lados opostos no embate que se formava. Percorrer esses espaços de produção de opiniões e defesas de soluções é um movimento imprescindível da etnografia para compreensão do campo político que passou a se constituir com a presença da obra. A usina, enquanto uma entidade mobilizadora que transcende as simples delimitações do canteiro de obras operou agenciando incontáveis espaços de prática política, que vão desde a educação diferenciada dos povos indígenas, aos projetos de reestruturação urbana de toda cidade de Altamira. Com promessas que lembram o slogan setentista dos cinquenta anos em cinco, a construção da usina assumiu uma série de compromissos de desenvolvimento urbano e contrapartidas socioambientais presentes nas Condicionantes e no Plano Básico Ambiental (Eletronorte, 2009), previstos a partir dos Estudos de Impacto Ambiental - EIA/RIMA (Eletronorte, 2009), por sua vez assegurados pela legislação ambiental, que é mais uma conquista da redemocratização e do movimento ecologista. Contudo, o programa arrojado de medidas de desenvolvimento estrutural para região sempre esbarrou nas, mais outras, controvérsias da obra, sobre as fronteiras entre público e o privado que o empreendimento suscita, um dos fatores agravantes para implementação das ações. Embora hoje seja possível avaliar melhor todas as incongruências das promessas feitas ${ }^{70}$ é inquestionável indicar o quão impactante foi a presença da usina na conformação de inumeráveis demandas, que embora tenham um horizonte de atendimento no mínimo questionável, foram catalizadores de arranjos políticos que por sua vez permanecem em aberto. Esses são alguns dos ingredientes que compõem o cenário político atual entre os interlocutores da pesquisa. Ainda, é preciso admitir, a presença da obra criou alguns vetores particulares para veiculação de determinadas demandas dos indígenas que habitam as beiras do rio Xingu e principalmente a cidade de Altamira, antes abafadas e oprimidas. Embora o resultado da presença de Belo Monte signifique, em termos gerais, a continuidade de um modelo de desenvolvimento econômico ensimesmado, que ignora sensivelmente os próprios princípios supostamente alegados de

\footnotetext{
${ }^{70}$ Ver: Dossiê ISA (2015)
} 
respeito aos direitos dos povos nativos e tradicionais, observa-se para a situação dos indígenas citadinos e ribeirinhos uma estrutura específica que permitiu a consideração da existência dessa população, problematizando seus direitos enquanto povos originários da região. Os estudos de viabilidade e avaliação ambiental $^{71}$ realizados para construção da obra foram obrigados a considerar a presença dos indígenas fora das aldeias, então denominados como "desaldeados", e que estavam "invisíveis" como população indígena para a estrutura burocrática do Estado. Esse momento converge com o movimento de mobilização política durante a época dos estudos de Belo Monte que irá instituir o reconhecimento do "índio citadino", categoria inclusiva que foi defendida pelos indígenas durante Assembleia dos Povos Indígenas do Médio Xingu em contrapartida ao discurso oficial até então veiculado que os denominava como "desaldeados". A produção pontual de conhecimento, que pode ser considerada um avanço involuntário do projeto Belo Monte, subsidiou a necessidade de reconhecimento do fenômeno específico, chamando a atenção dos órgãos do Estado dentro do processo de construção da obra que vem sendo construída. Conquanto não se possa afirmar, olhando atualmente, que a situação implicou numa política pública específica e consistente, é sensível a ampliação dos canais de acesso dessa população que veio no bojo das transformações veiculadas, direta e indiretamente pela presença de Belo Monte, como por exemplo a criação de uma Coordenadoria Técnica Local (CTL) pra atendimento dos indígenas citadinos e ribeirinhos, ocupada por Elza Xipaya, importante liderança citadina.

Que a presença de Belo Monte viria a ser um fator de influência incomensurável sobre toda região foi um prognóstico que muitos alertaram e que pouco se levou em conta da forma necessária. Agora em outro momento, em que a obra já avança para sua fase final, é possível e necessário fazer alguns balanços dessas transformações que se espalham sobre todos os cantos. Tarefa que, se levada ao limite, beira o inconcebível tanto quanto é a magnitude da barragem, porém a etnografia pretende reter algumas nuances de episódios que puderam ser acompanhados durantes os quase cinco anos de visitas do pesquisador à região, e que apontam alguns significados e proposições dessas inflexões sobre a organização política entre os interlocutores da pesquisa. Esse recorte é mais uma determinação do campo, por assim dizer, uma vez que desde a primeira visita à região, ainda em no ano de 2010, até a última, a

\footnotetext{
${ }^{71}$ Ver: Capítulo 3 da dissertação.
} 
poucos meses atrás (julho de 2015), foi inevitável lidar com o avanço das consequências de Belo Monte, as conturbações durante seu ápice, e finalmente, o atual início de seu declínio. Essas consequências estão concentradas nas alterações da rotina do dia-a-dia que cada interlocutor passou de maneira diferente conforme a interferência da obra em suas vidas, indo desde a simples menção de parentes empregados na obra, até a situação limite de um impasse diretamente sofrido nos processos de realocação de moradia. Ao mesmo tempo, de acordo com a experiência etnográfica experimentada, foi possível acompanhar as atuações políticas das lideranças citadinas voltadas principalmente para as disputas relacionadas às ações que envolveram as contrapartidas da construção da usina (PBA-CI e Condicionantes, mais a frente explicados). Além dessas, a questão da realocação urbana foi fundamental para a modificação de engajamentos e articulações políticas entre os atores e famílias indígenas afetadas, e firmou novas forças no cenário do movimento indígena citadino. Nesse contexto a etnografia pôde perceber como eram operadas categorias política nativas, ou seja, a despeito de todas as influências externas impostas pela presença do empreendimento com todos os seus apêndices observou-se a persistência dos modos próprios de compreensão e organização das demandas políticas entre os interlocutores da pesquisa. Significa dizer que todos esses dispositivos burocráticos e contra-personalistas do aparato institucional (da empresa Norte Energia, criada para construção de Belo Monte até o escritório do Ministério Público Federal na cidade, por exemplo) atuaram em meio a valores de proximidade e afinidade, como também entre disputas e declarações de conflito veiculados pelos atores políticos do movimento indígena. A tensão entre concepções contrastantes da noção de bem comum é um ponto fundamental para compreensão das controvérsias produzidas no campo político atual da questão indígena citadina. Para tanto é preciso ir além de uma dicotomia purista e tendenciosa que localiza no Estado (e seus agregados diretos, como a empresa construtora, no caso de Belo Monte) o lugar da impessoalidade institucional, uma vez que a própria estrutura formal que se constituiu para a construção de Belo Monte, seja diretamente, ou indiretamente para sua viabilização, mesmo aquela que opera na denúncia dos abusos infligidos durante a obra, faz uso de informações e práticas oficiosas que exploram as ligações pessoais que compõem esse campo político. O bem comum é então a prerrogativa para que se explore essas "artimanhas" interinstitucionais que se instalaram na dinâmica das escolhas e decisões políticas no universo altamirense acometido por Belo Monte. Efeitos perversos podem ser notados quando há a transposição imediata do bem comunitário, veiculado pela liderança e/ou representante, e o bem coletivo, criando as incontáveis histórias de irregularidades e embates que perfazem as ações das contrapartidas de Belo Monte. Ao mesmo tempo é preciso afastar-se do olhar 
viciado e pré-concebido do que é bem comum, e de como esse coletivo é estruturado, uma vez que as interconexões entre anseios especificamente pessoais e os valores compartilhados de parentesco, amizade e vizinhança são os fundamentos do viver bem ${ }^{72}$ defendido pelos indígenas da cidade. Todas essas advertências são essenciais para a consideração justa e séria do que afirmam e fazem os interlocutores da pesquisa, nesse momento, entre os atores do movimento indígena citadino.

\subsection{Primeiros passos do movimento indígena citadino}

O artigo de Silva (2010), “Organizações Indígenas na Amazônia Brasileira: um rápido sobrevoo", apresenta um importante levantamento que proporciona um panorama geral da rede de organizações indígenas na Amazônia brasileira, embora o autor alerte que as condições de sua pesquisa inviabilizassem um "um estudo propriamente antropológico, baseado na observação cotidiana das atividades desenvolvidas por cada uma dessas organizações". O artigo argumenta como as "organizações, que se apresentam ora como movimentos sociais, ora como associações voluntárias, ora como organizações não governamentais, em diversas esferas das políticas públicas na Amazônia, alteraram radicalmente um espaço em que as agências governamentais, até muito recentemente, reinavam com exclusividade". Por meio de dados quantitativos e qualitativos o artigo dá algumas pistas de como pensar sobre a crescente organização associativista nesses contextos indígenas amazônicos, proporcionado por um novo cenário caracterizado pelo acesso a um "mercado de projetos" (Albert, 2000). O artigo dialoga com Albert (2000), que analisa como a universalização de uma pauta social e ambiental, amparada pela ideia de desenvolvimento sustentável e participativo, criou um novo espaço de atuação política dos movimentos indígenas. Embora a etnografia pretenda apenas um recorte sobre o movimento indígena de Altamira, fundamentalmente sobre o movimento citadino e sua atuação no contexto dos empreendimentos hidrelétricos para a região, considera fundamental reter das sugestões contidas no artigo de Silva (2010) a percepção dos modos em que se desenvolveram as organizações políticas indígenas na Amazônia. Esses modos revelam a tensão entre esquemas e concepções internos a organização e aqueles expressos por instâncias políticas demarcadas externamente, proporcionando novas situações em que os atores refazem formas de aliança e

\footnotetext{
72 Ver: Capítulo 3 da dissertação
} 
conflitos oriundos da própria prática de auto-organização. Fazendo uma distinção entre movimento social e associações voluntárias, o artigo descreve como o primeiro é sempre conduzido por lideranças carismáticas, sem a necessidade de consolidar o marco institucional regulado por procedimentos de representação, sendo normalmente criados em torno de uma mobilização em favor de determinada causa, "organizando ações coletivas, sem fazer uso de regimentos ou estatutos". Já o associativismo cumpre com a ideia de representatividade formal, definindo contornos institucionais mais precisos e, embora tenda a nascer de determinadas demandas especificas, passa a mobilizar esforços em questões não especificamente políticas, como atividades assistenciais e recreativas, por exemplo. "Se, na cultura política brasileira contemporânea, os movimentos sociais
produzem "companheiros" e "lideranças", as associações voluntárias definem
"membros" e "representantes", que passam a falar em nome de seus
"associados" e de suas "bases", que podem ser moradores de um bairro,
portadores de doença crônica, colegas de profissão e assim por diante".
(SILVA, p. 8, 2010)

Tomo a tipologia como esquema explicativo para a compreensão das forças centrípetas e centrífugas que operam na organização e mobilização política entre os interlocutores da pesquisa, muito mais do que formas antagônicas de atuação. A etnografia a seguir descreve como o movimento indígena citadino de Altamira toma forma: sua gênese em torno de determinas questões, que marcaram o processo de abertura de associações, que depois foram obrigadas a se reposicionar diante dos novos cenários que criaram novos movimentos e associações, impondo desafios à mobilização e unificação em torno de propostas políticas compartilhadas. Além desses, a dissertação acolhe a sugestão do artigo que observa no cenário das organizações políticas indígenas da Amazônia resiliências constitutivas da força coletiva desses processos que, no limite, veiculam tensões cosmopolíticas:

"Os dados que acabamos de observar revelam também mundos infletidos por outras formas de solidariedade, residuais do ponto de vista da cooperação internacional, mas centrais do ponto de vista das culturas de seus atores, como o parentesco, a segmentaridade, a vizinhança, a chefia e assim por diante. A proposta aqui esboçada, como hipótese de trabalho, de que o fenômeno das organizações indígenas emerge na encruzilhada de diversos códigos talvez nos ajude também a situar algumas polêmicas que ele continua suscitando, na assim chamada antropologia da ação, seara que no Brasil denominamos 
tradicionalmente de indigenismo e, mais recentemente, de etnodesenvolvimento". (SILVA, p. 9, 2010).

\section{$* * *$}

A existência da Coordenadoria Técnica Local (CTL) exclusiva para os indígenas citadinos e ribeirinhos, com a coordenação de Elza Xipaya, neta do velho Aricafu Kuruaya, é uma vitória do movimento indígena que começou com a organização das mulheres Xipaya e Kuruaya em busca do direito ao reconhecimento de suas origens por meio da organização política conjunta. Esse episódio da história coletiva dos Xipaya e Kuruaya da cidade se confunde com a trajetória pessoal de Elza Xipaya, sua liderança imprescindível na mobilização dos indígenas moradores de Altamira, quando deram os primeiros passos para a institucionalização da luta política:

"Ela surgiu assim né: em 1998, eu vim pra Altamira, eu morava na aldeia junto com os índios Kuruaya e aí eu vim pra cidade devido aos meus filhos, que eu trouxe pra estudar, porque lá não tinha a série adequada pra eles e eu fui professora lá 4 anos, porque não tinha professora mesmo, a FUNAI não reconhecia os Kuruaya nessa época. Então lá, como tinha muita criança, eu comecei a dar aula, ia pro garimpo, e extraia ouro e comprava material; os pais compravam material. Aí que eu vim trazer meu filhos pra cidade pra estudar. Quando foi com três, quatro meses eu fui convidada pelo CIMI pra participar duma reunião com os indios da cidade, que tinha um rapaz que ele estava querendo ver a quantidade de índios que tinha na cidade, e eu me interessei pelo caso. O nome dele é Marcos, e aí eu fui nessa reunião e a gente convidou oito indígenas mulheres pra participar, e dessas oito a gente ficou como o movimento das mulheres indígenas. Daí no mesmo ano eu participai de uma reunião em Manaus do movimento das mulheres indígenas (...) Aí eu participei, fiquei nove dias em Manaus, então aquilo foi um aprendizado pra mim, porque eu nunca tinha saído pra participar de evento, de assembleia, de encontro, daí eu fui aprendendo como eu ia trabalhar aqui”.

O trecho apresenta uma série de episódios da trajetória da interlocutora que revelam aspectos fundamentais da organização política dos Xipaya e Kuruaya da cidade, e mesmo 
daqueles que hoje habitam as Terras Indígenas demarcadas ${ }^{73}$. Conforme é apresentado, tal movimento se inicia apenas no final da década de 1990, depois das iniciativas de demarcação das terras Kuruaya no rio Curuá, e Xipaya no rio Iriri, e já distante do momento em que se fez sentir presente o frisson da possibilidade de construção da hidrelétrica de Kararaô no rio Xingu. Durante esse período de relativa suspensão do projeto hidrelétrico a movimentação no sentido de atuar na defesa dos direitos da população indígena na cidade sempre foi apoiada pelo Centro Indigenista Missionário de Altamira (CIMI), sensível a presença dos indígenas em Altamira. Embora outros agentes que trabalham junto aos indígenas, como a FUNAI por exemplo, já tivessem o conhecimento da presença desses indígenas, não era possível ter a exata magnitude dessa população ${ }^{74}$, e nem se dava a devida atenção ao fenômeno. Segundo Patrício (2000), que realizou sua dissertação de mestrado com os Xipaya e Kuruaya entre os anos de 1998 a 2000, essa lacuna era fruto das dificuldades de reconhecimento da população citadina enquanto indígena ${ }^{75}$ :

"O órgão tutor, por exemplo, não os reconhece como índios. A justificativa é
que pelo fato de estarem vivendo há muito tempo na cidade, perderam as
características indígenas e já construíram um outro tipo de vida que não
condiz com a do índio aldeado. Entretanto, isso não impediu que as ajudas
individuais fossem dadas, ou ainda, que no relatório UHE Kararaô (1998),
produzido pela FUNAI - ADR - Altamira em colaboração com alguns
antropólogos, fossem levadas em consideração as famílias que vivem na
cidade. Quanto ao CIMI, sabe que existem muitos índios na cidade. O
relatório do padre Ângelo Pansa (1985), mostrou isso. O CIMI percebe-os
como índios, apesar da dificuldade de compreender o que é ser um índio
citadino. Só muito recentemente a atenção para as suas necessidades entrou na
pauta das discussões e produção de projetos". (PATRíCIO, p. 23, 2000)

O cenário encontrado pela autora compreende o momento inicial da iniciativa de organização política entre os indígenas moradores da cidade. Contudo, como está sugerido no

\footnotetext{
${ }^{73}$ A frente serão retomadas algumas questões que envolvem a criação das terras Xipaya e Kuruaya dentro do universo político das famílias da cidade.

${ }^{74}$ Para uma apreciação dos levantamentos populacionais dos indígenas moradores de Altamira, ver Capítulo 3 Entre Parentes.

${ }^{75}$ Silva (2010) também apresenta dados sobre a questão da etnicidade do ponto de vista das organizações indígenas, em que o mercado de projetos é um dos meios principais para auto-organização e gestão própria dos recursos: "Para muitos representantes dessas organizações, a conquista deste mercado corresponde também a um imperativo nos processos de afirmação identitária dos povos indígenas frente à sociedade brasileira, diante de agências com as quais os povos historicamente mantêm relações marcadas pela desqualificação de sua capacidade para gerir os recursos naturais de seus territórios, seus projetos de desenvolvimento e até mesmo seus planos de futuro". (SILVA, p. 7, 2010)
} 
trecho de Elza, o reconhecimento dos Xipaya e principalmente dos Kuruaya já era travado pelo pedido de demarcação das Terras Indígenas, em áreas onde já habitavam algumas famílias. A trajetória da família da interlocutora, que já havia sido moradora de Altamira no passado, conforme relata sua mãe, Tereza Xipaya, também perpassa pela residência junto aos Kayapó na aldeia Kriketum (TI Kayapó), depois no município de Tucumã, e posteriormente entre os Kuruaya onde hoje é a aldeia Curuá, antigo Cajueiro. Embora a trajetória familiar não corresponda, com todas suas paradas, aos movimentos migratórios que caracterizam o histórico de ocupação recente dos Xipaya e Kuruaya de Altamira, ela indica como esses movimentos pendulares são imprescindíveis para compreender a territorialidade desses grupos. Mesmo que Elza Xipaya sempre tenha tido ligação com a cidade Altamira, local onde viveu ainda criança, foi retornar apenas adulta para cidade quando considerou necessário que os filhos continuassem os estudos. Já na cidade, em contato com os parentes que já viviam ali, incorporou-se às discussões auxiliadas pelo CIMI que pretendia ter mais clareza sobre quem eram e em que situação viviam os indígenas moradores da cidade, no sentido de mobilizar essas grupos esparsos na cidade. Por sua vez essa mobilização também vinculava-se, como dito anteriormente, à luta pelo reconhecimento das Terras Indígenas, para onde muitos dos Xipaya e dos Kuruaya se mudariam, como ocorreu com grande parte dos irmãos de Elza, por exemplo.

\subsection{Os Xipaya e os Kuruaya: reconhecimento étnico e as Terras Indígenas}

Esse é o contexto que produziu novas configurações para as relações entre os Xipaya e Kuruaya, de modo que é preciso relacionar o histórico de migração e as genealogias familiares apresentadas nos capítulos anteriores, tendo em vista que essa interposição analítica permite reter alguns sentidos fundamentais da produção política entre os interlocutores. Se relembrarmos o relato de Firmino Kuruaya exposto no Capítulo 3, o mesmo menciona sobre a situação de coabitação na aldeia Curuá (Cajueiro) entre os Xipaya (principalmente da família de Elza) e os Kuruaya (em sua maioria pertencentes a família extensa de Firmino) que não foi mais possível a mesma convivência que era atribuída aos seus antepassados. Interessante relacionar à essa afirmação a convergência genealógica, ou mais claramente, o parentesco entre as famílias, uma vez que o avô de Elza era irmão do avô de Firmino. Essa condição da família de Elza suscita as mais variadas insinuações sobre a origem Kuruaya de sua família. Assim como foi discutido anteriormente, no espaço privado que abrigou as conversas sobre as 
trajetórias pessoais e dos grupos Xipaya e Kuruaya, a problematização de quem é o que sempre foi apontada do ponto de vista do emissor, ou seja, situando aquele que afirmava que fulano era isso ou aquilo tem-se que essa atribuição relaciona-se com a própria identificação de quem está classificando. As nuances dessas classificações e categorias estão presentes como fatores fundamentais para composição das estratégias políticas, impossíveis de serem destacadas dessa produção simbólica, por mais que analiticamente a etnografia tenha optado por apresentá-los separadamente. Quando Firmino afirmava que essa convivência não era mais a mesma, lembrava que a iniciativa dos Xipaya foi a migração para o Entre-rios, no rio Iriri para recuperação de sua antiga aldeia. Mais do que uma controvérsia sobre identidade étnica, o episódio refere-se às alianças entre parentes e estratégias políticas que irão dialogar, a partir de então, com os dispositivos de reconhecimento oferecidos pelo Estado, como foi a demarcação da Terra Indígena. Pois Elza Xipaya afirma ser também Kuruaya, embora a amalgama Xipaya-Kuruaya não seja anunciada em seus discursos, o que pode ser explicado, em parte, por esse conjunto que intersecciona as identificações estabelecidas por meio das articulações políticas expressas em termos instrumentais, com o da identificação étnica. Embora o último seja um ingrediente fundamental deve-se ter atenção de como é manipulado pelos interlocutores em compasso com os conflitos e alianças que estão o tempo inteiro produzindo parentesco, ou seja, política. Significa dizer, no limite, que "indianizam” esses esquemas rígidos das categorias de identificação étnica ao seu favor, quando assim é possível.

\subsection{As matriarcas e movimento de mulheres}

Um momento fundamental da militância indígena citadina foi a convocação dos idosos para a identificação dos antepassados das famílias, a partir do interesse em fazer o levantamento dos indígenas moradores da cidade, como revela Elza Xipaya:

"O tempo foi passando e eu comecei a fazer o cadastro, saí de casa em casa, de porta em porta, vendo quem era índio mesmo. Com auxílio do CIMI, eu pegava todos os dados e eles digitavam tudo pra mim, depois quando a gente estava com 40, 50 cadastros a gente sentava com as matriarcas, com as índias mais velhas, e começava a perguntar se essa pessoa era índio ou não era, quem eram os pais, mães... E aí elas iam dizendo quem era índio, então aí elas iam dizendo e a gente ia separando (...) Era a tia Maria, a Dona Kirinapãe, o Paulinho, 
a Isabel Xipaya, a Maria filha do Paulinho, a Payá, Seu Luís... Eram essas pessoas que ajudavam a fazer o reconhecimento”.

Categoria fundamental para pensar a produção simbólica entre os interlocutores, o reconhecimento das "matriarcas", as indígenas mais velhas portadoras do conhecimento dos Xipaya e Kuruaya, é também um decisivo momento político afirmativo, em que o protagonismo feminino é revelador de como se deu a resistência indígena na cidade. Como revelaram as descrições anteriormente apresentadas na dissertação ${ }^{76}$, o termo expressa menos um "sistema matriarcal" e mais o modo como a organização social e cultural dos Xipaya e Kuruaya foi sendo reelaborada ao longo dos períodos históricos em que a migração era uma alternativa às incursões de ocupação de seus territórios, o que transformou e definiu a condição desses grupos. A expressão é fruto de um momento de valorização da identidade indígena, construído nos termos da origem ancestral que é resguardada pelas matriarcas, que por sua vez passaram a operar diante dos critérios de identificação étnica enquanto referências para a descendência indígena, a qual o molde do pertencimento étnico está acostumado a lidar. Nesse sentido essas mulheres "reaparecem" no contexto expresso pela interlocutora, quando houve a mobilização para identificação dos indígenas moradores da cidade, o que exigia dessas pessoas idosas a comunicação de seus conhecimentos antes negligenciados pelas políticas indigenistas ou mesmo pelos próprios descendentes, como costumam destacar. Ainda que a ascensão do termo "matriarcas" seja debitaria desse processo político que serviu de base para o reconhecimento étnico e a reivindicação de direitos, tanto na cidade como na retomada das terras no Iriri-Curuá, ela está apoiada sobre a organização Xipaya e Kuruaya na cidade que manteve sobre as mulheres, normalmente casadas com um não indígena, a manutenção dos laços com os saberes e práticas tradicionais, como pôde ser observado na descrição da culinária das famílias, por exemplo ${ }^{77}$. Embora a lista citada de matriarcas contenha os homens idosos, também reconhecidos por seus conhecimento dos Xipaya e Kuruaya, é sensível como os interlocutores expressam pela categoria aludida, muitas vezes transliterada como "as patriarcas", sua afetividade e respeito com relação a herança materna, traduzida pelas lembranças nostálgicas da infância, seja do gosto da comida, do adorno confeccionado, da cantiga entoada, entre outros. Desse conjunto, permite-se compreender

\footnotetext{
${ }^{76}$ Ver especialmente Capítulo 3, em que muitas das matriarcas aparecem como ego nas genealogias apresentadas e nos relatos citados.

${ }^{77}$ Ver: Capítulo 3 da dissertação
} 
como da tenacidade feminina Xipaya e Kuruaya depreendeu-se as bases da organização política indígena citadina, conforme relata Elza Xipaya:

“Em 2000, a gente fez o movimento de mulheres. Pra poder ver se a gente conseguia fazer um projeto, pra trabalhar com artesanato. Então isso tudo foi pela Prelazia do Xingu, porque a gente não tinha ainda uma associação, o movimento de mulher... A gente ficava em dúvida, ou faz uma associação, ou o movimento de mulheres, pra poder ter documentos (...). A gente fez um projeto pra fazer artesanato, e aí nesse projeto a gente encaminhou pra Cáritas, eles responderam esse projeto, o valor era muito pouco, mas deu pra começar. Daí fizemos esse projeto com cinquenta mulheres, daí eu executei esse projeto né (...) Mas assim, projeto pra índio fora de terra indígena é muito difícil de ser aprovado. Porque assim: 'vive na cidade, já tem contato com o branco, já tem oportunidade de recurso, não sei do que...'. Mas a gente ainda chegou a fazer mais projetos, todos pequenos, todos foram aprovados' (...). Então a gente foi amadurecendo, e em 2001 a gente disse: 'não, agora a gente vai trabalhar em cima de uma associação', porque cresceu, tinha mais de 200 indígenas, ai a gente ficou assim, 'poxa agora não dá mais pra ser só um movimento de mulher'. Então a gente passou noventa dias trabalhando em cima da associação, estudando estatuto; vendo o que era o regimento, o que a pessoa tinha que respeitar; a diretoria ela ia trabalhar, ela não é assalariada, ia trabalhar em benefício da comunidade, a comunidade que ia ajudar... Não que a associação ia ter lá um fundo, um projeto que a associação ia te beneficiar, ia pagar a diretoria, tudo eram os associados mesmo. (...). A gente não fez o estatuto dela diretamente só para duas ou três etnias, a gente fez, como o nome diz, associação dos índios de Altamira, então ela abrangeu todas as etnias, tanto faz, Kayapó, Canela, Xavante... Todos eles a AIMA tem, legalmente”.

O trecho expõe os episódios que marcaram a construção da Associação dos Indígenas Moradores de Altamira (AIMA), hoje presidida pelo irmão de Elza, Luís Xipaya. Como ressalta a interlocutora, a associação nasceu da organização das mulheres Xipaya e Kuruaya, mas culminou na criação de uma associação comunitária que abarcava todos os indígenas da cidade. Mesmo com todas as dificuldades indicadas desse início de criação da associação, ainda não são mencionadas as disputas e cisões internas, que serão mais tarde recorrentes no contexto político influenciado por Belo Monte, a despeito da variedade de associados que se juntaram na entidade. A amplitude do número e da diversidade de indígenas associados no 
movimento encampando por Elza Xipaya também se confunde com os acessos que a interlocutora foi capaz de mobilizar a partir dos conhecimentos políticos e mesmo burocráticos dos dispositivos de proteção social do Estado, ganhados com a experiência adquirida com movimento indígena. Distante ainda da integração no corpo de servidores da FUNAI de Altamira, a interlocutora já atuava na associação demandando uma série de prestações que a mesma tinha dificuldade em respaldar. A consequência da atuação da interlocutora nesses espaços permitiu que contribuísse em outros órgãos como o Distrito Sanitário Especial Indígena (DSEI), no qual foi servidora entre os anos de 2000 a 2002 . Esses episódios, em que se dá o "reconhecimento" dos indígenas moradores da cidade pelos órgãos do Estado, podem ser considerados a matriz do gabarito político que irá formar novas lideranças e as novas configurações do movimento indígena citadino:

"E ai a gente entrou numa fase de os índios dizerem 'olha Elza estou com vontade de aposentar, por causa da idade' então a gente foi vendo, de um lado fazendo o cadastro, e de outro pegando o nome dessas pessoas que queriam se aposentar, que tinham idade. A FUNAI sabia, mas nunca se envolveu, se interessou. Daí eu fiz esse cadastro, peguei umas quarenta pessoas e aposentei. Trouxe pra FUNAI, que eles não queriam aposentar, que eles eram da cidade, não tinha mais vínculo... E aí é essa questão de discriminação, de não querer... Pra eles índio era só aquele que está lá na aldeia e pronto. Eu disse 'vai ter que aposentar ele e pronto! O direito dele é índio, está na lei', e aí eles aposentaram esses índios todos que eu trazia. Mas a FUNAI nunca virou a cara pra mim, eles nunca disseram: 'Elza tu ta fazendo por tua conta, nós não vamos assumir, nós não temos responsabilidade...'. Eles nunca disseram isso, sempre falaram: 'olha, bom trabalho, teu trabalho é muito bonito, gosto, porque tem muitos índios que estão precisando, aqui na FUNAI a gente não tem gente adequada pra estar fazendo isso'. E ai eu estava trabalhando voluntariamente, nunca recebi nada por isso, até mesmo porque eu via os próprios parentes sofrer. E aí eu fiz esse cadastro, encaminhei pra FUNAI de Altamira, FUNASA, Ministério Público e Defensoria Pública, tanto pra cá pra região, como pra Brasília. Aí quando foi tirada a saúde da FUNAI pra FUNASA, eu entrei como conselheira. Foi no ano de 2000, teve um seminário e eu fiz parte e ai eu fui trabalhar no DSEI". 78

\footnotetext{
${ }^{78}$ Silva (2010) observa esse padrão nos dados levantados pela pesquisa: "Isso para não falar da participação em conselhos, que também mobiliza um expressivo contingente. Para se ter uma ideia, a pesquisa registrou 73 participações de representantes de organizações indígenas em conselhos de saúde, 25 em conselhos de educação e 64 em conselhos de outra organização" (SILVA, p. 6 2010). Ainda, indica a área de saúde como uma das principais no desenvolvimento do mercado de projetos, "com uma oferta de volumes de recursos
} 
A pesquisadora Marlinda Patrício (2000) pôde acompanhar esse momento indicando como o fortalecimento da relação entre os parentes que viviam nas aldeias e na cidade foi determinante para o reconhecimento dos dois grupos perante o dispositivos do estado:

"É dentro desse processo que os movimentos de afirmação e reconhecimento da identidade dos Xipaia e Curuaia aldeados e dos citadinos convergem, mesmo com problemas. Um percurso que exigia de seus membros uma compreensão da situação de forma mais abrangente do que só os aldeados tinham direitos. A temática da saúde alavancou o movimento de reconhecimento da identidade citadina e foi muito bem aproveitado por Elza Xipaia, que convocou todos os índios que moram na cidade de Altamira para as reuniões que poriam a par dos conhecimentos.”. (PATRÍCIO, p. 92, 2000)

\subsection{O cadastro dos indígenas de Altamira e movimento indígena citadino}

Um passo atrás, é preciso aprofundar as consequências de outro ingrediente crucial para a constituição do movimento indígena citadino, o que foi o chamado por Elza de "cadastro dos índios". Como pôde ser lido nos relatos apresentados, o apoio do CIMI durante os primeiros passos da militância política dos indígenas citadinos se deu a partir do interesse em identificar os indígenas que moravam na cidade. Engajando-se pessoalmente nesse projeto, Elza Xipaya construiu alguns mecanismos para conseguir realizar esse levantamento, como a participação dos idosos, enquanto referências sobre a origem dos indígenas cadastrados:

"Eu tinha dúvida: 'Será que eu to pegando um índio de verdade, ou eu to pegando um falso indio? Ele ta dizendo que é índio pra ele poder ser beneficiado daqui pra frente...'. Ai muitos chegavam na minha porta dizendo: 'Ah eu sou índio!', 'Tu é índio, de que etnia?' 'Ah eu sou Xipaya de tal lugar...' 'Não, tu é parente de quem? Tu tem que ter um parente né? Porque Xipaya, Kuruaya, Juruna são dessa região, hoje tão espalhados por aí, pelo mundo afora, mas eles são daqui'. Então eu ficava pesquisando na época, a gente tinha vivo o finado Paulinho, que foi uma pessoa que muito me ajudou, e a finada Kirinapãe, foi outra índia que também me ajudou muito mesmo, já velhinha, mas ela conhecia todo mundo. Eu andava, mais o Raimundo e o Paulinho de casa em casa, ele dizia: 'Olha esse aqui é indio, é filho de

sem precedentes, graças à terceirização dos serviços de saúde favorecida pelo modelo dos Distritos Sanitários Especiais Indígenas, a partir de 1999, e a implementação dos projetos apoiados pelo PDPI, a partir de 2001". (SILVA, p. 9, 2010). 
fulano...' Desde os bisavós, avós... Ele conhecia. Então aquilo, eu confiava nele né? Porque uma pessoa com oitenta, setenta anos, dizer que não é? Então foi assim, foi um trabalho muito dedicado mesmo".

A aposta de Elza Xipaya levantou desconfiança de muitos indígenas na época que não acreditavam que os moradores da cidade poderiam "conseguir alguma coisa com isso", como foi expresso em vários momentos. Contudo a mesma ressalta como os mais idosos estavam empenhados em contribuir nesse projeto, quase como uma ação final da última geração que havia se formado ainda nas beiras do rio Iriri e Curuá e desejava o reconhecimento de suas origens. A importância dos idosos nesse processo, principalmente das matriarcas, como demonstrado anteriormente, tem uma repercussão para além da identificação das origens dos parentes dos habitantes Xipaya e Kuruaya de Altamira, como contribuíram também, por exemplo, para as tentativas de recuperação e revitalização das tradições de canto, da pintura, entre outros. Contudo o protagonismo dos indígenas nesse projeto trouxe um procedimento de descrição e inscrição das relações de parentesco que deflagrou um efeito de intensidade particular não só para a formação dos coletivos no movimento indígenas, como também na própria composição das relações entre as famílias. Esse instante da trajetória desses grupos é também muito importante para compreender como se dá a passagem entre concepções e vivências de gerações diferentes, que irão refletir nas readequações das novas estratégias políticas de sobrevivência. Significa compreender, por exemplo, como Elza Xipaya foi capaz de traduzir determinados componentes que operam noções de pertencimento e identificação entre os Xipaya e Kuruaya, expressos em termos de parentesco e convivência, em esquemas de identificação afeitos ao modo analítico ego-centrado e linear que a noção de parentesco suporta nas genealogias. Uma vez que o espaço dos grupos citadinos expressa-se nessa fronteira que conflui em Altamira, ele é capaz prover a condição para que esses deslocamentos sejam experimentados na construção de alternativas de vivência entre os interlocutores. Contudo é importante para a etnografia precaver-se contra a tentação de solucionar os impasses criados por esses intercruzamentos por meio de esquemas rígidos préconcebidos, como sugere a carga que determinadas categorias carregam como, por exemplo, as que formulam diagramas genealógicos, que por outro lado tem uma importância particular para constituição política entre os interlocutores da pesquisa. É nesse sentido que as noções de parentesco e mistura foram primeiramente convocadas durante o capítulo terceiro da dissertação, para assim adentrarmos os espaços em que essas categorias estão em mais íntima 
relação com influências exteriores, embora as mesmas não possam ser empiricamente desvinculadas desses contextos, conforme as descrições sugerem. Para compreender essa interação entre as matrizes do movimento indígena citadino, suportando valores de parentesco e vizinhança, ao lado das mais variadas influências "externas", como de servidores da FUNAI, por exemplo, é preciso avançar nessa história que começa com a contribuição do CIMI para a construção do cadastro de indígena que dará origem a primeira associação citadina. Seguindo adiante, já num período de controvérsias políticas que não deixam de ser familiares, irá se inserir também a contribuição dos pesquisadores, antropólogos ou não, que também participam da produção política entre os interlocutores, seja diretamente no movimento indígena, a partir de atuação institucional ou em estudos acadêmicos e de avaliação de impactos ambientais. Mesmo durante os primeiros passos do movimento indígena citadino já estava presente a pesquisadora Marlinda Patrício (2000) com sua pesquisa de mestrado que também contribuiu para a identificação e levantamento dos indígenas moradores da cidade. Além dessa é interessante notar a recuperação que Elza faz da pesquisa de Magalhães (2005), quando o pesquisador atuou também fazendo um levantamento entre os indígenas:

“Aí em 2004 teve o Antônio Carlos Magalhães por aqui, dai ele começou a fazer outro levantamento (...). Aí ele pegou todos os processos (de registro do nome indígena ${ }^{79}$ ) e levou pra defensoria, e entregou pra Fábio Rangel (promotor). Daí ele disse que podia pegar os documentos desses índios pra acrescentar o nome, mas ele não fez a genealogia, que essa que é mais importante, ele não fez. Daí tudo bem, botou dentro da defensoria e ficou. Daí teve uma campanha de documentação, daí a Xipainha chama aqueles índios que queriam botar o nome indígena, levou pra defensoria, quando chegou na defensoria eles foram barrados, porque não tinha a genealogia, não tinha o que comprovasse que ele era índio (...). Então quando a gente bateu dentro da defensoria e disse: 'Olha aqui a relação dos índios pra botar o sobrenomes deles' disseram: 'não, embarga esse trabalho da defensoria, a defensoria não vai fazer nada disso, porque a gente precisa ter todo um estudo antropológico pra saber quem não é índio, quem é, quem é o parente... Então a gente está com uma equipe aqui de antropólogos, biólogos, sociólogos pra fazer isso".

\footnotetext{
${ }^{79}$ Uma demanda bastante forte do movimento indígena citadino é a inclusão do "nome indígena", que significa, em geral, a incorporação legal da etnia (Xipaya, Kuruaya, Juruna...) como sobrenome.
} 
Na situação supracitada, o contexto do movimento indígena citadino havia mudado desde o primeiro cadastro com ajuda do CIMI, com a criação de mais uma associação indígena, a Associação Kuruaya Akarirá, atualmente chamada Kirinapãn, cuja liderança principal é Maria Augusta Xipaya, a Xipainha. Trabalhando mais próximo desses Kuruaya o pesquisador não aproveitou o trabalho já iniciado de Elza Xipaya, como havia feito a pesquisadora Patrício, e elaborou um levantamento próprio dos moradores indígena na cidade. Os processos, citados no trecho, referem-se ao levantamento de quem eram as pessoas que não tinham sobrenome indígena e, segundo Elza, não avançaram na defensoria pela ausência da demonstrações da origem indígena. A causa apresentada desse insucesso, na visão que hoje tem a interlocutora, é um exemplo de como as categorias externas, como as oriundas dos estudos com função de laudo, foram sendo incorporadas no manejo corriqueiro da militância política entre os indígena de Altamira. Às palavras de Elza Xipaya, embora ressoem por meio desses conceitos exógenos que constroem os discursos de identificação étnica, é importante relacionar todo o contexto intra-indígena dos enunciados, que estão expressando também alianças e conflitos políticos, que irão mobilizar, por meio das controvérsias do parentesco indígena, amplamente influenciada pelas leituras oficias como a veiculada pela defensoria, um espaço de conquistas e que por isso está sempre em disputa também. É preciso lembrar que essa leitura de Elza Xipaya é posterior ao fato ocorrido, de modo que hoje a mesma também se enquadra como servidora da FUNAI, além de uma liderança do movimento indígena:

“Em 2009, ai foi quando chegou a equipe para fazer o levantamento fundiário dos indígenas que moram na cidade nas áreas que vão ser impactadas (por Belo Monte). Eu não estava mais na AIMA, trabalhando diretamente, estava em casa fazendo meus trabalhos mesmo em casa. E aí essa equipe chegou, começou a conversar comigo, me procurando porque que tinha parado... Bom uma andorinha só não faz verão né? Eu lutei tanto pela AIMA, mas os índios não me ajudavam (...). Aí foi quando a gente foi fazer o cadastro, batendo nas portas, conversando, dizendo como era pra ser, isso em 2009. E aí os colegas também me ajudaram, a AIMA estava com uma divida de mil e duzentos reais, e aí eles fizeram a vaquinha, me ajudaram e pagaram. Disseram: 'Elza, não quero que tu saia da AIMA. Fica na AIMA porque você é uma pessoa muito importante, que conhece, sabe lidar com as pessoas, conhece todo mundo. A gente chegou aqui em Altamira fomos bater na FUNAI, pedir informações dos índios atrás da FUNAI, a FUNAI não tinha informação, não sabia, não conhecia e nem sabia onde, que rua, que bairro que esses índios moravam. Então a FUNAI 
encaminhou a gente pra cá, pra ti, porque tu foi uma pessoa que trabalhou muitos anos, que conhece índio por índio'. Então eu fui, puxei documento, dei conta de documento pra eles, levantamento, tudo eu dei pra eles; eles disseram: 'não mas tudo bem, a gente quer que você fique na coordenação, com oito índios pra poder começar a fazer o cadastro' (...). Pra gente poder fazer o cadastro desses índios que iam ser impactados nas áreas afetadas, pra ter a realocação como índio, tinha que ter a planta de genealogia pra saber se é índio de verdade (...). Então a gente começou a abrir o mapa e ver os vínculos, a gente começou a fazer as bolinhas de quem é parente de quem (...). A gente conseguiu pegar os nomes das pessoas e chegar desde os avós até...".

Quando questionada se o primeiro cadastro feito com o apoio do CIMI era uma genealogia, a interlocutora esclareceu que era parecido, contudo sugeriu que o levantamento não pressupunha a mesma metodologia e também que o mesmo não findava na inscrição em um diagrama, como foi feito no estudo ambiental. Pode-se considerar que esse ciclo de estudos de identificação e levantamento da população indígena de Altamira tem seu desfecho, que também é seu ápice, a partir da presença do empreendimento de Belo Monte. Como era de se esperar, a entrada desse grande agente transformador também reverberou sobre as formas com que o movimento indígena citadino iria passar a atuar, mesmo nas questões mais elementares da militância. A primeira dessas confluiu o interesse da equipe de antropólogos, sociólogos e outros pesquisadores ${ }^{80}$ do EIA/RIMA (2009) com as informações e experiência obtidas por Elza Xipaya durante seus anos de atuação antes e depois da criação da AIMA. Durante a época em que começaram os diagnósticos dos impactos de Belo Monte sobre os indígenas de Altamira, a interlocutora estava distante da atuação direta na associação, então foi convidada a participar dos estudos ambientais, compondo a equipe de cadastramento censitário que abrigava ainda outros indígenas instruídos a colher uma série de informações socioeconômicas, ainda escassas sobre essa população. Aproveitando o conhecimento e a participação dos indígenas, o estudo destacou-se pelo caráter de laudo, com informações detalhadas sobre a condição dos indígenas moradores da cidade Altamira e da Volta Grande

\footnotetext{
${ }^{80}$ A equipe do componente indígena citadino de Altamira e ribeirinho da Volta Grande do Xingu foi coordenada pela socióloga Ana Cerqueira Cezar Corbisier, e integrada pelos antropólogos, Paulo Serpa, Luís Roberto de Paula e Mirella Poccia; o economista Fábio Ribeiro; a socióloga Mayra Pascue; o arquiteto e urbanista Humberto Kzure; e os pesquisadore Samuel Medeira Luna, André Michelis e João Pavese. A equipe indígena era supervisionada por Elza Xipaya de Carvalho, e composta pelos entrevistadores Xipaya Raimundo Ferreira, Marilene Ferreira, Darilene Xipaya, Antonio Xipayra e pela Kuruaya Marly da Silva.
} 
do Xingu, que até então não estavam sendo considerados especificamente nos EIA/RIMA anteriormente elaborados para a construção da hidrelétrica de Belo Monte ${ }^{81}$. A presença do empreendimento influenciou mesmo na incorporação pela FUNAI do atendimento aos indígenas antes considerados "desaldeados" que agora queriam ser tratados como citadinos e ribeirinhos, em mais um momento intimamente relacionado à trajetória pessoal da interlocutora. Após a conclusão dos estudos foi convocada uma reunião pela FUNAI de Brasília para esclarecimentos sobre a situação de Belo Monte, que contou com a presença das lideranças e da população indígena da cidade e concluiu na indicação de Elza para integrar a CTL dos indígenas citadinos e ribeirinhos de Altamira:

"E lá nessa reunião foi acordado, como eu era liderança na época dos índios citadinos e ribeirinhos eles disseram: 'bora ver se a gente acha um canto pra encaixar a Elza, porque ela é uma pessoa muito importante, porque tudo que a gente precisa ela sabe, ela ajuda a gente. Então não daria pra ter uma CTL, uma coordenação só pros índios citadinos?'. Então isso foi aprovado por todas as lideranças, a FUNAI de Brasília fez o documento e encaminhamos. Isso em 2009. Em 2010, passou o ano todo, no fim de 2010, dia primeiro de dezembro de 2010 chegou minha portaria de Brasília, que tinha me aceitado pra trabalhar na FUNAI. Nisso eu também não dei nenhum passo pra continuar com a AIMA, ela estava lá bacana, bonitinha, mas eu não quis me envolver. Aquilo começou uma preocupação, 'quem vai assumir a AIMA agora então?' Porque foi uma luta, foi uma batalha, foi um sofrimento, pra gente chegar no ponto que a gente chegou e mostrar pro Brasil todo que se a gente se unir tem força, tem o poder de chegar e construir o que a gente quer. Então aquilo foi me preocupando... 'Será que eu vou ter que encaminhar um documento dizendo que a gente vai ter que a acabar com a AIMA?' Não dá né?".

As intersecções entre as demandas do movimento indígena citadino e os interesses trazidos com a presença dos estudos de Belo Monte, que se sucedem nos relatos apresentados, dão pistas de como esses ingredientes do campo político institucionalizado irão se acomodar frente as transformações iminentes. Do ponto de vista das associações indígenas citadinas, com muitos participantes do movimento contra a construção da barragem, esse cenário de

${ }^{81}$ Os Estudos de Viabilidade (Muller, 1989) do projeto Kararaô já contemplavam a presença das famílias indígenas de Altamira e eram bastante enfáticos quanto a importância dessa população da cidade no contexto dos impactos do empreendimento de então. Contudo, o acesso integral ao laudo foi possível apenas após a defesa, o que dificultou a apreciação completa de seus dados para incorporação na dissertação. 
implantação prevista criou um quadro de apreensão e expectativas, que foi se remodelando conforme as contrapartidas da construção foram sendo prometidas, realizadas e depois modificadas ou mesmo não executadas, criando um campo de disputas que, embora bastante inconstante e desorganizado, passava ser um dos poucos canais de acesso a direitos e assistências sociais, mesmo que inconsistentes. Segundo as falas da ex-presidente da AIMA e uma das pioneiras do movimento citadino de Altamira, essa conjuntura inicial permitiu a ascensão de seu papel institucional na entidade comunitária ao cargo ocupado no órgão governamental, o que tornou sua posição um exemplo bastante particular para se pensar as consequências desse entrelaçamento entre "ordens" de pensamento e prática políticas a princípio distintas. Contudo é sempre necessário remeter-nos ao modo como a institucionalidade do movimento indígena citadino foi se produzindo, com base na mediação entre a organização comunitária indígena e os dispositivos de produção de políticas indigenistas, sejam oriundos das entidades não-governamentais ou governamentais. $\mathrm{O}$ relato anterior de Elza Xipaya concentra a tensão entre funções com responsabilidades e com lógicas diferentes, mas revela, acima de tudo, as tentativas de ajuste entre as percepções e práticas políticas trazidas do ambiente comunitário, que é subentendido como familiar extenso, e os arranjos impessoais e burocráticos que tanto uma presidência de associação como um cargo público exigem. O privilégio da condição particular da interlocutora é expor de forma contundente essa frágil reordenação, a qual, no limite, todo indígena citadino, mas principalmente aqueles envolvidos no movimento indígena, estão sujeitos.

\subsection{Fortalecimento cultural e o movimento indígena}

“Todo Kuruaya é parente" foi a resposta de um interlocutor à outro quando questionado se tinha algum parentesco com outro Kuruaya de outra família, seguido da expressão de incerteza sobre qual poderia ser o grau de relação com ele. Esse tipo de afirmação, recorrente durante a experiência de campo, parece esvaziar de conteúdo a ideia de parentesco entre os Xipaya e Kuruaya de Altamira, mas é mesmo seu caráter genérico que expõe como esse argumento tem sempre um significado político, e por compreender essa natureza deve ser sempre entendido enquanto feito ${ }^{82}$. Fazer esse parentesco entre os interlocutores é um complexo que não se dilui em esquemas de relação consanguíneas ou

\footnotetext{
${ }^{82}$ Sobre as formas de fazer parentesco, o presente capítulo se soma as descrições da produção de parentesco apresentadas no capítulo anterior.
} 
conjugais, ou mesmo pode ser definido a partir da instrumentalização alçada a argumento, como é apresentada no momento em que são convocados a responder as perguntas sobre sua origem, expressando a "raiz", ou seja, indicando os antepassados mais ou menos longínquos. Ter os mais idosos como referência para a história das origens dos Xipaya e dos Kuruaya, no esforço de reconstituição da memória coletiva dos grupos, é tão importante quanto manter espaços de atualização dos laços afetivos e pragmáticos que sustentam as noções de pertencimento e reciprocidade entre as pessoas dos dois grupos aparentados que a muito tempo habitam a cidade de Altamira. Durante o surgimento do movimento indígena citadino, um de seus principais momentos consistia na reunião de todos os parentes para celebração dos costumes respeitados como tradicionais. Recriando um espaço de vivência ${ }^{83}$ entre as diferentes gerações, esse movimento foi politizado inicialmente como "resgate cultural" para mais tarde, já num momento discussões avançadas, ser requalificado como ação de "fortalecimento cultural" dos indígenas citadinos. Essas transformações são fruto das novas conjunturas que propiciaram às lideranças tanto a formação no movimento indígena nacional, mantendo contato com diversas questões de outros povos, quanto também passaram a receber influências dos novos agentes trazidos pelo contexto das hidrelétricas previstas, com um panorama bastante duradouro. Ao mesmo tempo é uma releitura bastante influenciada pelas exigências, impossíveis de serem relevadas, dos inquéritos que incidem sobre a condição indígena dos interlocutores, seja do ponto de vista institucional ou mesmo oriundo da desconfianças dos conterrâneos não indígenas. Ainda hoje é possível experienciar situações em que as gerações mais novas, já nascidas e criadas na cidade, expressam o estranhamento em se reconhecerem enquanto indígenas, uma vez que estão imersos num ambiente de referências exotizantes e preconceituosas sobre o que é ser indígena. A fina composição entre a autovalorização das origens e heranças dos antepassados, e a incorporação e aceitação das influências consideradas típicas do mundo não indígena é uma jogo que continua a ser experimentado no dia-a-dia dos interlocutores, como pode ser depreendido das receitas culinárias por exemplo. Os contextos vividos são índices fundamentais para compreender para onde pende essa delicada balança, e mesmo que se possa indicar predominâncias em determinadas épocas, as reminiscências podem vir a futuramente ocupar um espaço de

\footnotetext{
${ }^{83}$ Silva (2010) indica nos dados colhidos em sua pesquisa como essas práticas não podem ser lidas apenas por meio de um lógica instrumental, sendo que "as organizações indígenas, de um modo geral, não se dedicam exclusivamente à realização de projetos tais como as agências financiadoras os concebem, mas também atendem a uma variada demanda que vai, como vimos, da organização de atividades de lazer à participação em manifestações políticas na cidade, do transporte de mercadorias para a comercialização à hospedagem de parentes em trânsito, da organização de trabalhos comunitários à prestação de serviços de despachante". (SILVA, p. 7, 2010).
} 
consagração. A problematização da cultura pelo movimento indígena é um exemplo de como esse tema é muito caro aos Xipaya e Kuruaya, ocupando um lugar capaz de negociar as demandas políticas mais vitais com a experiência criadora da coletividade e união:

“A AIMA ela era assim... Eu falo para o Luís também, a AIMA hoje tem tudo. Era para sentar todo mês com as comunidades, com as famílias e dizer, 'vamos fazer uma comida, vamos passar o dia... O dia do índio, só nós famílias... Não importa que dia seja, porque dia do índio é todo dia. Na minha época eu fazia assim, eu marcava uma reunião com todo mundo, sempre eu marquei assim começo de mês, dia 5, dia 10, fim de semana também. $O$ que eu fazia? Ficava bolando um plano... 'Olha se eu marcar um dia, final de semana, pra gente fazer uma almoço, pra todo mundo, vocês topam?' Ai um dia, 'Como que nós vamos fazer pra comer? Não temos dinheiro! A AIMA não tem recurso'. Eu dizia, 'eu quero saber se nós estamos juntos nesse dia? A alimentação deixa que eu assumo a responsabilidade. Só que daqui a gente vai ter que tirar uma equipe pra limpar o espaço, pra lavar louça e pra fazer comida' (...) Então quando eu fazia a reunião no dia 2, dia 3 eu já fazia o ofício, eu pegava nome de supermercado e telefone e fazia um ofício, pedindo a comida para cada lugar que eu conhecia, eu pedia oficialmente. Todos esses supermercados, graças a Deus, nunca disseram um não pra mim (...). O que sobrava de comida, a gente deixava um pouco pra cada família. Hoje eu vejo as associações com tanto e ninguém se reúne, pra fazer um dia alegre, pra sentar, pra ver como está fulano. O que eu acho que está faltando dentro dessas associações hoje é união".

O período rememorado por Elza Xipaya foi quando além de organizarem o cadastro com ajuda das matriarcas e anciões, os mesmos também eram solicitados por terem guardado a memória dos mitos, dos cantos, das danças e da língua, o que os alçou ao posto de patronos da cultura tradicional, função que a categoria de matriarca também alude. Esse saber foi reconhecido como uma valor incalculável por aqueles que se engajavam na questão indígena, deflagrando então o processo de valorização e tentativas de promoção das tradições que corriam perigo de serem esquecidas com a morte dessas pessoas. Um lembrança sempre muito cara aos Xipaya e Kuruaya, a festa do kariá foi revivida então pelos esforços das associações Akarirá (atual Kirinapãn) e AIMA, que propunham a reunião das famílias com apoio da estrutura da Prelazia. Sobre esse período relata Josa, filha de Payá, importante matriarca sempre lembrada como uma colaboradora fundamental desse movimento: 
“A mamãe nunca aprendeu a falar bem mesmo, ela falava um pouco enrolado. Agora só que sozinha ela não falava não, ali ela começou a falar quando eles inventaram um negócio aqui de uma associação, 'vamos reunir, vamos juntar os índios...' Ai vinham pegar ela, pegar a Akarirá, pegar o Paulinho, pegar a Maria do Nãe. A gente começou a associação, daí era ali nos padres né. A Kirinapãe, que era uma das mais antigas... Daí eles passavam e juntavam e ficavam falando. Quem ensinou a Elza Xipaya, foi minha mãe. Elas que começaram, lá no salão dos padres. Aí a gente ia todo mundo, dançava, era legal (...). Eu dançava com eles ali no Matias quando a gente ia. No salão do 23, no são dos padres. Eu já era mãe desses meninos tudinho, nós erámos da associação da Elza, todo mundo era, depois que teve outra (...)".

A descrição de Patrício (2000) de uma apresentação organizada pela AIMA com cantos, danças e pinturas ensinadas pelas matriarcas, durante o ano de 1999 no evento organizado pelo CIMI, "O dia dos excluídos da América Latina", expõe um pouco do modo como foi construído esse movimento de valorização, promoção e divulgação das expressões artísticas e culturais que resistiram entre os Xipaya e Kuruaya:

"Antes de entrarem no salão para a "Apresentação", ficaram em um local para
concentração, de onde ninguém deveria mais sair. Permitiram que meus
colaboradores e eu entrássemos. Desde nosso último encontro em outubro de
1999 até aquela data haviam assumido responsabilidades étnicas e seus
comportamentos estavam compromissados com o grupo. Suas peles estavam
marcadas por diversas retocagens de pinturas, a conversa era outra e girava
em torno do que queriam de agora em diante e de como iriam fazer. Ficou
evidente o quão orgulhosos ficaram ao verem que os idosos poderiam ensinar
para os jovens suas origens. E um dado importante, as quatro gerações
estavam envolvidas num trabalho de persistência e em serem reconhecidos e
marcar essa diferença, que iniciou com a reivindicação à saúde". (PATRÍCIO,
p. 97, 200)

É muito feliz a reelaboração que atualmente fazem os interlocutores desse movimento de valorização das expressões culturais dos Xipaya e Kuruaya. Revisto como uma ação de fortalecimento, a ideia do resgate permanece, porém mais consciente do sentido pernicioso que carrega, estereotipando-os como indígenas destituídos de cultura. Essa noção, ainda muito forte mas já politicamente combatida entre os Xipaya e Kuruaya, tem um lastro substancial quando pensamos que está situada onde há o perigo do desaparecimento, desencadeado pela 
opressão, pela vergonha e finalmente pela indiferença. Assim, por mais que o uso político do termo seja prejudicial, ele traduz a consciência desse perigo, que por sua vez é combatido tanto do ponto de vista militante, quando reivindicam ações de reconhecimento étnico ou apoio para salvaguarda dos saberes e práticas tradicionais, quanto repercute entre as famílias e gerações criando novas subjetividades capazes criar novas possibilidades de compreensão e ação orientadas pela disposição em viver melhor. A reatribuição ritual da dança, do canto e da pintura é um pequeno exemplo de como se misturam essas agências múltiplas nessas propostas que se inspiram nas tradições ancestrais buscando criar alternativas para os novos desafios impostos. Nada mais consequente indicar a presença da construção da hidrelétrica de Belo Monte enquanto uma disrupção perigosa mas também catalizadora dessas novas configurações políticas capazes de inovar e recriar.

$* * *$

No marco do movimento de fortalecimento cultural pude me engajar na participação observante (Albert, 1995), contribuindo com o projeto de valorização do patrimônio cultural dos indígenas citadinos e ribeirinhos de Altamira, inserido dentro do Plano Básico Ambiental do Componente Indígena (PBA-CI), fato que também instaurou-se enquanto uma contrapartida da proposta de pesquisa. Esse campo de atuação, intimamente relacionado com a proposta de pesquisa, desde que teve início a primeira ida a trabalho para cidade de Altamira ainda no ano de $2010^{84}$, até a última colaboração nas atividades de promoção e valorização das expressões culturais dos Xipaya e Kuruaya de Altamira, determinou de modos diferentes as implicações da pesquisa com os interlocutores. A repercussão mais profunda incide diretamente sobre a possibilidade de contribuir com o movimento indígena citadino e ribeirinho, dando apoio à ações não apenas de salvaguarda do patrimônio cultural, como também de fortalecimento institucional das associações, como por exemplo, apoiando a criação das associações dos Juruna Tubyá da cidade, e Kuximã da Aldeia São Francisco, de ribeirinhos da Volta Grande do Xingu. Vivenciando o dia-a-dia da atuação política entre diferentes atores do cenário indigenista atual em Altamira, ficou evidente como as influências de Belo Monte, sobre o movimento indígena citadino, principalmente por meio da execução das ações compensatórias e mitigadoras dos impactos da construção da obra, criou um modo específico de militância e atuação política, encorajando novas estratégias e novos atores nesse

${ }^{84}$ Ver Introdução da dissertação. 
cenário. Seu saldo, por exemplo, foi a criação de novas associações representantes de indígenas citadinos e ribeirinhos. Além das já mencionadas AIMA e Kirinapãn, surgiram a Associação Tyoporemô dos Povos Indígenas Nativos do Médio Xingu; e a Associação Nativa Kuruaya de Altamira - INKURI, além das supracitadas que participai do processo de criação. Essa explosão associativista no movimento indígena citadino refere-se a dois fatores que podem ser dispostos diametralmente, tal como a etnografia usou em outros momentos como recurso analítico, em que de um lado há uma dinâmica própria do movimento indígena, mas que é instigada pelas intervenções que propiciam certas conjunturas capazes de abrigar essas novas resoluções. Partindo do último seria necessário, para ter um noção abrangente desse processo, compreender como se desenvolveram as ações compensatórias de Belo Monte, desde a sua proposição até sua execução. Sem condições de implementar tal empreendimento totalizante, a dissertação irá se restringir a apontar alguns momentos considerados fundamentais durante as conversas com os interlocutores e a partir das observações durante a experiência de campo.

Tabela 7 - Quadro de associações citadinas e ribeirinhas em Altamira

\begin{tabular}{|c|c|}
\hline $\begin{array}{c}\text { Ano de criação } \\
\text { (registro em cartório) }\end{array}$ & Nome \\
\hline 2002 & Associação Indígena dos Moradores de Altamira - AIMA \\
\hline 2006 & $\begin{array}{c}\text { Associação Agrícola Representante do Índio Regional de Altamira } \\
\text { Xipaia e Kuruaia - KIRINAPÃN }\end{array}$ \\
\hline 2012 & $\begin{array}{c}\text { Associação Tyoporêmo dos Povos Indígenas Nativos Ribeirinhos } \\
\text { do Médio Xingu }\end{array}$ \\
\hline 2013 & Associação Indígena Nativa Curuaia de Altamira - INKURI \\
\hline 2014 & Associação Indígena Juruna - TUBYÁ \\
\hline 2015 & Associação Indígena Juruna Kuximã da Aldeia São Francisco \\
\hline Não registrada & Associação Xipaya Uawmã \\
\hline Não registrada & Associação Xipaya da Cachoeira do Jericoá \\
\hline Não registrada & Associação indígena da Ilha da Fazenda \\
\hline
\end{tabular}

\subsection{Belo Monte e o novo movimento indígena citadino}

Recuperando o processo de elaboração dos estudos ambientais, seja relativo aos citadinos ou aos aldeados, identificamos, de forma geral, o rigor analítico com que esses diagnósticos foram feitos, dando a eles o caráter de laudos, como já foi dito, cujo objetivo específico, a avaliação dos impactos da obra sobre as populações indígenas da região, não os desqualifica enquanto documentos que contém informações preciosas, coletadas por equipes 
qualificadas, muitas vezes integrando antropólogos com vasta intimidade com o grupo indígena. Essas circunstâncias de estudo, que permitiram a inclusão das Terras Indígenas que estavam sendo desconsideradas pelo processo de licenciamento ambiental, estão diretamente relacionadas às conquistas do movimento indígena, ambientalista e indigenista que também reivindicou a incorporação dos indígenas citadinos, como foi exposto anteriormente. A consequência desse trabalho foi a elaboração do Plano Básico Ambiental do Componente Indígena (PBA-CI), um ousado planejamento que organizou ações conjuntas para dar conta de várias questões que afetam os indígenas do Médio Xingu (fundiária, saúde, educação, cultura, atividades produtivas) para ser implementado durante um período de trinta anos, e que considerou tanto as obrigações da empresa construtora quanto as do poder público. $\mathrm{O}$ plano foi pactuado em reuniões e plenárias com as lideranças e a população indígena após o término dos estudos ambientais. Até esse momento, o cenário da construção de Belo Monte cumpria com alguns protocolos ambientais, até mesmo com a suposta assinatura do então presidente do Brasil, Luís Inácio Lula da Silva, de termo garantindo que outras hidrelétricas não seriam construídas no rio Xingu ${ }^{85}$, embora já houvesse a grande controvérsia sobre a consulta prévia aos povos indígenas (Convenção 169 da OIT). Iniciada a construção da obra, no final do ano de 2010, tem-se um gradativo quadro de descumprimentos e readequações dos programas de mitigação e compensação dos impactos da obra. Dentro do cenário indígena, a morosidade para a validação das ações do PBA-CI levou à decisão, acordada entre os órgãos ambiental e indigenista do governo com a empresa executora da obra, de elaborar uma medida momentânea conhecida por Plano Emergencial. Segundo Gilson Kuruaya:

"Aí quando teve, por exemplo, essa discussão... A proposta do EIA, e começa então a discussão se os índios aceitam... Acho que foi em junho, ou julho... A proposta da questão da barragem nessa perspectiva da garantia das implementações que estavam previstas dentro do EIA. Eles chamavam de PBA... Que ainda ia ser construido. Daí todo mundo dizia 'Calma aí, a gente vai esperar esse negócio ser construído? Não a gente precisa de alguma coisa até que tenha um PBA'. A gente chamou de lista, eles chamaram de (Plano) Emergencial. Isso era pra começar em agosto, começou em setembro de 2010. Começou com rancho, com cesta de comida, aí depois passou né: voadeira, motor... até caminhonete! Mas o interessante, que a gente tinha uma briga com o coordenador da FUNAI, porque nós apresentamos projeto. Nós, a (associação) Kirinapãn, apresentamos projeto de enriquecimento dos quintais, que era horta nos quintais; um restaurante com vários pontos na residências das famílias indígenas,

${ }^{85}$ Não foi encontrada qualquer confirmação desse termo. 
pra fazer as comidas tradicionais. Aí a gente tentou aproveitar esse recurso do emergencial pra alavancar esses projetos. Ai foi uma briga feia”.

Nesse período surgiram uma série de denúncias de pagamento a lideranças, beneficiamento de determinados atores, uso de recursos para benefício próprio e apenas pelos aliados, que contribuíram para o acirramento dos conflitos internos entre os próprios indígenas:

"A gente teve alguns momentos: 'Ah porque os Kuruaya querem assim, porque os Xikrin querem isso, porque os Parakanã querem aquilo...' Então tinham essas diferenças. Aí teve momentos que até índio ameaçou índio assim: 'se tiver etnia tal nessa reunião não vai prestar! Se tiver tal, não vai acontecer, vai ter morte!',

Concebido como medida momentânea e circunstancial o Plano Emergencial perdurou até o início de 2013, com ações desestruturadas, baseadas muitas vezes nos chamados "acordos de ocupação de canteiro" quando a militância indígena isolada de cada povo decidia reivindicar o que achava de direito paralisando a construção da obra. Esse quadro deflagrou a desarticulação do movimento indígena, que se cindia internamente, repercutindo na quase completa desmobilização da luta contra a barragem ente os povos habitantes do Médio Xingu. Ao mesmo tempo o contexto de transformação trazido com as chamadas "listas de compras", impingiu a necessidade de se rever qualquer medida compensatória ou mitigatória que antes previa os impactos trazidos pela obra. Segundo o relato de Elza Xipaya, já servidora da FUNAI nessa época, as dificuldades dobraram com a chegada do Plano Emergencial:

“O Plano Emergencial foi o que mais complicou nossa vida. Ele podia até ser um plano emergencial... Para mim um plano emergencial deveria ser assim, se eu estiver errada me corrija: 'olha não dá pra gente executar esse ano porque nós temos que ainda estudar o restante'. O plano emergencial pra mim era, construção de casas boas, construção de escolas boas, fazer estrada nas áreas indígenas, fazer a demarcação das áreas indígenas... Agora quando eu vi a primeira lista de não sei quantas folhas, com trinta sacos de feijão, trinta sacos de açúcar, não sei nem quantos latas de óleo, quantas caixas de bolacha. Então aquilo pra mim não foi um emergencial, eles acharam que a gente estava passando fome, entendeu? Hoje você vai pra aldeia e os índios não querem mais plantar macaxeira pra tirar 
a farinha, não querem plantar o milho pra fazer o mingau, a mandioca, mais nada... Eles só querem vir aqui na cidade pra levar a bolacha. Nós não tínhamos índios diabéticos, agora nós temos porque são caixas e caixas de leite, de doce, de goiabada, de refrigerante, de manteiga... Então isso acabou com a vida dos índios. Então eles se acomodaram, porque eram barcos com toneladas de mercadoria. Aí o dinheiro que gastaram, do emergencial, em mercadoria, que não construíram as casas, não compraram os tijolos, começaram a fazer casa de madeira, agora hoje está tudo embargado. Já bateram o pé que querem a de alvenaria... Só deu confusão. Vem os índios citadinos, vem os índios ribeirinhos pra cima de mim, 'ah porque eu quero!' 'Não, espera aí, eu não mexo com sexta básica não'. Porque os índios da cidade são diretamente com as associações. Lá nas associações, tem curso, você vai tirar sua carteira de motorista, vai fazer um curso de computação... 'Não, mas eu não quero, eu quero é cesta básica' 'Então vão morrer de fome, porque as associações não vão te dar não!'. Os índios ribeirinhos do mesmo jeito, nós estamos capacitando, 'tu tem casa lá, tu mora lá?' Eu pegava a voadeira, cansei de fazer isso, sair daqui pra Ilha da Fazenda, pra Ressaca, pro Galo (todos na Volta Grande do Xingu), debaixo de chuva e sol, vendo se ele morava de verdade. Porque muitos receberam e era mentira. Tinha casa no Mutirão (bairro na cidade), tinha casa não sei onde... Aí quando a gente desce com a equipe pra fazer a vistoria, cadê o índio? Nem lá ele pisou o pé! Esse emergencial foi um inferno! Pra estar hoje como está? Os índios tudo doido aí, porque não tem mais isso, não tem mais aquilo. Estão vendo que não tem mais na aldeia... Agora acabou tudo mesmo. Pior coisa que a FUNAI fez foi ter fechado esse contrato de emergencial. Ela podia ter batido o pé, 'Não! Vamos esperar que ninguém vai morrer não! Vamos executar o que está no PBA'. E outra, como o emergencial saiu na frente do PBA, aí encostaram. Agora vai sair aos trancos e barrancos".

O longo relato alude à conturbação pela qual, não apenas a interlocutora como todo o movimento indígena, com todas as suas facetas, passou durante esse momento, quando a obra atingia seu ápice, trazendo milhares de pessoas em busca de trabalho para a região e agravando todos os problemas estruturais, desde o saneamento básico, passando pela segurança pública e chegando à oferta de lazer. A cidade de Altamira encontra-se até então como um grande canteiro de obras, tanto literalmente pela execução das obras de reestruturação urbana, como metaforicamente, com seus habitantes tendo que refazer a vida, seja mudando de casa ou mudando hábitos para se readequar a nova dinâmica da cidade. Desse "material destrutivo", que o empreendimento foi produzindo, foram construídas 
alternativas dentro do movimento indígena citadino, que ainda se estruturam no bojo dessas alterações. Podemos retomar, a partir do contexto descrito, como se deu a criação das novas associações da cidade, a maior parte oriunda da divisão interna que ocorreu nas associações já existentes $^{86}$. Ainda, durante o Plano Emergencial cada associação que nasceu expressava uma determinada demanda não atendida entre os indígenas citadinos e ribeirinhos. A Tyoporemô foi criada para "lutar pelos direitos da população indígena ribeirinha da região do Médio Xingu" conforme relata sua presidente Socorro Arara ${ }^{87}$ :

"Nós estamos com uma briga tão grande com a FUNAI aí (...). A FUNAI não fez PBA pra nós... Índios da cidade e ribeirinhos, que moram fora da terra indígena demarcada, pra FUNAI não era índio. Então ela não fez consulta prévia nenhuma aqui do Xingu, deram licença pra fazer barragem, mas não fizeram consulta prévia. Então, pra nós ribeirinhos foram eles que colocaram uma condicionante, o emergencial... Botou pra dar motor, gerador, um kit pra fazer a casa que não dá pra fazer um barraquinho de 4x4, fizeram um kit de construção pra fazer a casa, que não dá pra fazer nenhum cômodo, porque é muito pouquinha madeira e só cinquenta telhas. Foi a FUNAI que fez... Quer dizer, acho que foi a FUNAI junto com a Norte Energia. Agora acabou, agora nós estamos brigando pelo PBA, que no PBA que vai sair mais coisa pra nós. O PBA e o reassentamento que nós queremos. Vão precisar da nossa área, das nossas ilhas, que muito índio mora nas ilhas, mora nos lotes... Essa cerâmica bem aqui (São Sebastião) vai ser lago, e isso aqui está cheio de índio. Índio que tem suas ilhas, seus lotes, por aqui abeirando... Aí FUNAI e Norte Energia mandaram fazer cadastro... Aí eu estou com uma lista, que já mandei protocolar no Ministério Público Federal, nós não queremos dinheiro, nós queremos outra terra”.

${ }^{86}$ Em seu artigo Silva (2010) apresenta dados sobre os motivos para a criação das organizações indígenas, destacando os principais: em primeiro lugar a necessidade de um instrumento de atuação política para conquista de direitos territoriais e assistenciais (principalmente saúde e educação); e em segundo lugar o desejo dispor de meios para angariar recursos para desenvolvimento de projetos de geração de renda e apoio a produção. Além desses indica como justificativa bastante citada para criação de organizações, a motivação por "política interna": "Em outras palavras, como reações de desagravo a organizações controladas por facções políticas adversárias, revelando em muitos casos também disputas político-partidárias, religiosas ou competições entre agentes externos rivais, que também disputam entre si financiamento e prestígio" (SILVA, p. 5, 2010).

${ }^{87}$ A liderança está imersa numa teia de controvérsias sobre sua origem indígena que, no entanto, não cabe à etnografia reconstituir na medida em que está preocupada com a auto-organização do movimento indígena, e não com critérios de legitimidade ou autenticidade. Embora essa polêmica também perpasse os próprios atores do movimento, ela está sempre sendo refeita e reformulada por meio das aliançar políticas, sendo assim, a presente análise reserva o direito deles próprios se garantirem, como disse Xipainha, "Se ela quiser ser o que ela quiser, deixa ela ser, ela luta por todos nós". 
Indicando uma carência que pode ser estendida também aos não indígenas moradores dos igarapés, ilhas e beiras do rio Xingu, a interlocutora reuniu em sua associação principalmente seus vizinhos, moradores da região do bairro São Sebastião (Muquiço) onde a própria mora, muitos dos quais dependem da geração de renda vinda da pesca e da agricultura nos lotes que mantém em outras áreas. A associação não tem uma "cara étnica", abrigando indígenas de várias origens, assim como a AIMA, mas, diferente dessa, é organizada mais sob o ponto de vista da habitação e ocupação do que numa perspectiva familiar. No trecho exposto acima se compreende as bases da organização política dessa associação, que parte de um espaço vago, a militância em prol dos indígenas ribeirinhos, muitos desses dissidentes das outras associações, para reivindicar o cumprimento das contrapartidas da construção de Belo Monte. Dentro desse espectro, a formação desses novos atores do movimento indígena de Altamira converge para alguns determinados pontos de ação, como a disputa pela execução das ações do PBA-CI, sendo que durante o período do relato, no início de 2014, ainda não havia a execução das ações para citadinos e ribeirinhos. Toda a formação dessa nova onda de lideranças e associações percorre mais ou menos esse caminho militante:

“Em Brasília eu fui, quando nós ocupamos o canteiro no mês de maio, mês de junho com os Munduruku. Aí fomos direto pra Brasília. Chegou em Brasília protocolei na FUNAI lá, Ministério Público Federal, na Presidência da República de Brasília, no Supremo Tribunal do Joaquim Barbosa também... No Ministério de Minas e Energia e no Ministério da Justiça. E estou lutando, com fé em Deus vamos conseguir nossos objetivos (...). Lá em Brasília foi assim: 'por que apelidaram vocês de indio ribeirinho e indio citadino?' 'Porque chamaram nós de indio ribeirinho né... 'Ai disseram 'índio é índio, qualquer lugar que está é índio, tanto faz estar na cidade, no outro lugar... Ele é índio, vocês não tem que deixar ninguém apelidar vocês de índio isso ou índio aquilo'. Ai sempre falo pros parentes aqui: 'nós temos nossos direitos, a gente tem que lutar porque a gente é índio, o mesmo direito que os parentes que estão morando lá dentro da aldeia nós aqui também temos'. Então eles fizeram um PBA igual do branco pra nós, e isso nós não vamos aceitar nunca, eu já falei com o Ministério Público, já fui brigar em Brasília, nós queremos nossos direitos”.

\subsection{Quem quer ser índio depois de Belo Monte?}


A visibilidade do movimento indígena e suas conquistas dentro do contexto de Belo Monte expuseram a delicada situação em que permaneciam todas as outras contrapartidas da obra, orientadas para a população não indígena, tanto que é comum ouvir na cidade "o quanto os índios conseguem as coisas da Norte Energia”, alguns comentários valorizando a eficiência política do movimento indígena, outros indignados com a oferta "especial” apenas aos indígenas. Desse caldeirão em ebulição destaca-se a intensa polêmica que se formou em torno de quem estaria sendo beneficiado injustamente pelas ações de contrapartida reservadas aos indígenas, essencialmente entre os citadinos e ribeirinhos, situação encontrada principalmente durante o período do Plano Emergencial. Esse quadro foi se agravando com o modo como se correlacionaram as ofertas de Belo Monte e sua veiculação a partir da estrutura política do movimento indígena citadino organizado em torno das associações, que por sua vez mantém seu próprio modo de atuação e de controle social, porém agora contaminado pela nova conjuntura. Essa nova cartografia política do movimento indígena citadino vem passando por um processo extremo de mudanças e aprendizagem da militância, desde as expectativas trazidas pela chegada do empreendimento até a redefinição das formas de atuação e readequação das pautas de mobilização já no contexto atual de conclusão prevista da obra. Mesmo durante os estágios iniciais essas rápidas guinadas podiam ser observadas, como indica o relato de Gilson Kuruaya:

"Aí até esse momento, a gente estava lutando contra, ninguém dava o braço a torcer. Era contra e não tinha nada que mudasse. Eu sei que aí chegou o EIA, no final do ano chegou o EIA. Aí em 2010, eu acho que foi... O novo coordenador (da FUNAI) chegou, parecia o milagreiro, o sedutor... Prometeu um monte de coisa que ele não dava conta. Todo mundo já sabia... Amigo, se tu quer fazer uma coisa, não prometa nada pra ninguém, não faça essa gafe, que é pecado. Mas aí a gente até acreditou muito, mas... O que eu te digo é o seguinte, prometa trabalho, não prometa ações, sabe? (...) Eu acho que foi a inexperiência e a imprudência (...)”.

Até então, com o Plano Emergencial, as promessas que se consumavam e pareciam dar certo passavam a se transformar também num problema tão grande quanto os próprios impactos trazidos diretamente pela obra, não apenas para os próprios envolvidos diretamente com sua implementação, como era o caso de Elza Xipaya, mas também entre os próprios atores do movimento indígena, como sugere Gilson: 
“O auge de luta com Belo Monte foi 2011. Depois que começou esse negócio de emergencial, em 2010... Aí as coisas começaram a acontecer em 2011, foi briga feia. Em 2012 a gente teve que se afastar mesmo do movimento. Foi uma pressão... E assim, eu lembro que em 2009 eu tinha uma presença muito grande, eu viajava demais (...)”.

Embora o recadastramento dos indígenas moradores de Altamira, após as conclusões do EIA/RIMA já na fase de monitoramento das famílias indígenas realocadas por Belo Monte $^{88}$, tinha como objetivo identificar apenas as pessoas que estavam nessa situação, ele também compreendeu a identificação de parte da população indígena não diretamente afetada pela obra - ou seja, vivendo em áreas que não seriam alagadas -, ainda num momento em que não se tinha a definição de como se daria esse processo de realocação. Durante o período desse trabalho, desenvolvido com o apoio da FUNAI, que já contava com a CTL dos Indígenas Citadinos e Ribeirinhos, houve o expressivo incremento do número de famílias indígenas identificadas ${ }^{89}$. Esse incentivo criado por Belo Monte foi o estopim para a mudança da abrangência do problema da autoafirmação entre a população descendente, de uma situação em que muitos relutavam em se reconhecer enquanto indígenas, ainda com o receio dos preconceitos e agressões, para essa fase seguinte, quando a oportunidade de se afirmar indígena, mesmo que onerosa no ambiente social como um todo, tornava-se não apenas possível como também desejável, no sentido do acesso que dava às contrapartidas diferenciadas trazidas com a construção da barragem. A intensa polêmica formada em torno das contrapartidas direcionadas aos indígenas da cidade e ribeirinhos se agravava com o período de indefinição sobre a execução das ações estabelecidas pelo Plano Básico Ambiental do Componente Indígena (PBA-CI) para os indígenas citadinos e ribeirinhos, após o início da obra. Posteriormente, já no ano de 2013, o PBA-CI passaria a ser executado como Plano Operativo do PBA-CI, resolução definida entre os órgãos do governo e o empreendedor. O Plano Operativo é caracterizado como detalhamento das ações do PBA-CI a serem implementadas pelo empreendedor durante cinco anos. O relato de Socorro Arara, citado no item acima, refere-se a esse período de passagem do Plano Emergencial para o Planto Operativo, quando os novos atores do movimento indígena foram obrigados a lidar com essas novas nomenclaturas passando a construir suas reivindicações em torno desses novos dispositivos da política indigenista.

\footnotetext{
${ }^{88}$ Ver Relatório de Cadastramento das Famílias Realocadas (Norte Energia, 2012).

${ }^{89}$ Os dados são apresentados no Capítulo 3
} 
Retomando os efeitos do Plano Emergencial, definidos como as primeiras ações de contrapartida oferecidas aos indígenas citadinos e ribeirinhos, somados ao início do recadastramento da população realocada pelo empreendimento, tem-se um ambiente perfeito para a criação dos conflitos e embates que se produziram na sequência. Além do efeito indicado de criação das novas associações, como exposto, que foi proporcionado pela dupla condição do novo contexto que permitiu dar forma a expressão das diferenças que se produziam internamente no movimento indígena citadino, esse ambiente de conflito entre o modelo de militância política operante no movimento e o aumento das demandas e da própria população indígena saturava os dispositivos de acesso e garantia de direitos que acabavam de ser estabelecidos pela própria presença de Belo Monte. Surpreendida por essa nova situação, a proto-estrutura de atendimento à população indígena da cidade, que na verdade não deixava de ser bastante precária, passaria então a ter de lidar não apenas com essa nova dimensão demográfica como também com essa nova dinâmica de reivindicação e expressão das demandas citadinas, como observa Elza Xipaya:

"Aqui na cidade apareceu essa polêmica, essa confusão. Aparecia índio toda hora: 'Elza eu quero isso, Elza eu quero aquilo... 'Pera aí, não é só chegar e ir pedindo, 'Quem é tu? Quem são teus parentes? Tu já foi cadastrado? Ta dentro da área impactada? Tu é ribeirinho?' 'Não...' 'Pois é, os índios que são da cidade vão procurar as associações, tu é sócio?' 'Então vá lá e te informe, pra associar, pra pode fazer...' 'Ah porque fulano recebeu um motor!' 'Sim ele recebeu porque eu fui lá, fiz o cadastro dele, porque eu sei que ele índio, ele tem todo o direito'. Ai começa a polêmica! Ah porque puxa de um, faz mais pra outro... Menino eu já aguentei tanto pau colega, na cabeça, que tu nem imagina!”

O tema, como afirma a interlocutora, é bastante polêmico não apenas porque expressa os conflitos internos do movimento indígena citadino, mas também na medida em que pode tornar-se um argumento para os discursos contrários aos acessos a direitos constitucionais dos povos indígenas, quando esses estão "integrados" a sociedade nacional, como as populações moradoras da cidade. A esse respeito a própria interlocutora uma vez comentou que durante uma viagem a Brasília um servidor da FUNAI exclamou que se no resto o Brasil fizessem o que estava acontecendo em Altamira, se referindo à CTL dos citadinos e ribeirinhos, "o órgão estaria perdido”. O debate diz respeito à necessidade de provarem ser indígenas perante os não indígenas, e mesmo que a interlocutora também opere de uma posição institucional do 
Estado, que sustenta o dispositivo de autorreconhecimeno e reconhecimento pela comunidade (ao falar da identificação dos parentes e do pertencimento as associações), esse procedimento demonstra-se insuficiente para abarcar todas diferenças internas a esse grupo tão heterogêneo quanto os chamados indígenas citadinos e ribeirinhos. À etnografia não cabe oferecer uma resposta a esse dilema colocado pela liderança e servidora da FUNAI, e menos ainda dar margem para interpretações errôneas, que irão se agarrar a critérios de indianidade que estão ausentes nas práticas e discursos entre interlocutores, pelo menos do modo rígido e esquemático que as categorias étnicas podem suscitar nos pensamentos limitados pela noção essencialista de identidade. Ao expressar essa tensão a etnografia pretende mostrar como o próprio movimento indígena é obrigado a recriar-se frente a esses novos desafios, não apenas externos como de Belo Monte, mas que despertam de seu próprio seio. Contudo, alguns pontos de apoio estão sempre presentes na prática política do movimento indígena citadino, oferecendo a credibilidade entre os interlocutores para construírem uma militância consistente com os valores comunitários compartilhados entre todos. Esse é o modo, retomando novamente, como a ideia de parentesco, contida nos discursos sobre a memória da origem familiar, constrói referências de pertencimento e reciprocidade, sempre atualizados em práticas de identificação, como a comensalidade, seja no âmbito da casa ou da associação. Por sua vez, essa estrutura sociocultural é a base da organização política do movimento citadino que lida com órgãos da política institucional e também cria entidades que são supra parentais. Hoje, um grande problema pra Elza Xipaya é acompanhar as "linhagens" de todos aqueles que a procuram para o reconhecimento da sua identidade indígena, por isso menciona a necessidade dessas pessoas estarem associadas às entidades que já são oficialmente reconhecidas como indígenas, e que na maior parte do tempo se baseiam na relação de parentesco e de coabitação como ponto de partida da organização política, assim como foi com a criação da própria AIMA, encampada pela interlocutora. Contudo, entre as diferentes comunidades ou arranjos parentais extensos, hoje em dia normalmente referenciados politicamente pela organização por meio das associações, os valores de parentesco e vizinhança permanecem como critérios fundamentais para a noção de identificação e pertencimento, porém a partir de então sempre elevados ao debate público que gira em torno das interferências trazidas por Belo Monte. Para aqueles que reivindicam, antes cabe garantirse perante seus pares, como informa Raimunda Kuruaya.

“Agora tem muita gente que quer ser índio... Demais! Eu conheço muita gente, é o que mais tem! (...) Lá no bairro onde eu morro todo mundo é índio... Aí vai conversar, pergunta 
alguma coisa: 'De onde foi que tu saiu? Cadê sua aldeia, onde foi tua aldeia?' Porque pra ser índio tem que ser assim né, precisa saber a origem dele... Então tu não é índio”.

\subsection{Bairro indígena: os desafios da renovação movimento indígena citadino}

Se o problema durante os primeiros passos do movimento indígena citadino passava pela identificação dos moradores da cidade, como forma de dimensionar o fenômeno e principalmente mobilizar os indígenas distribuídos nos bairros de Altamira buscando o acesso a saúde e fomentando a unificação dos grupos em torno da autoafirmação étnica e da valorização dos costumes tradicionais ainda preservados, essa coesão ganhou outros acentos conforme as interferências de Belo Monte passaram a afetar o dia-a-dia dos altamirenses. Os indígenas citadinos representam uma expressiva parcela da população que ocupa os igarapés e "baixões" da cidade, áreas sujeitas a alagamento no regime sazonal de chuvas e que estarão permanentemente alagadas após a construção do reservatório da usina. A situação dos indígenas realocados confirmou-se como uma das principais bandeiras e preocupações da renovação do movimento indígena citadino, vindo com a criação das novas associações. Dentre essas destaca-se a formação da Associação Nativa Kuruaya de Altamira - INKURI, presidida pela liderança Claudio Kuruaya, morador do bairro Jardim Independente II, e seu movimento de mobilização para aquisição de uma área de assentamento para os indígenas moradores de Altamira realocadas pela usina. No início formada majoritariamente em torno da rede familiar de Cláudio Kuruaya, todos moradores do tradicional bairro indígena, bem como por seus vizinhos, a bandeira do novo bairro encampada pela INKURI, e fortemente apoiada pela Associação Kirinapãn liderada por Xipainha, agregou uma expressiva parcela da população indígena citadina de Altamira, uma vez que essa é uma das principais afetadas pela realocação urbana de Belo Monte. Retomando uma antiga demanda que tinha sido formada durante o início do movimento indígena citadino, a criação desse bairro, onde poderiam se reunir as famílias indígenas de Altamira, incorporou as novas circunstâncias de Belo Monte e, pode-se afirmar, reavivou essa reivindicação que ficou abandona durante um bom tempo, tanto pelo movimento indígena, como pelas entidades responsáveis. Mais uma vez Elza Xipaya contribuiu para essa mobilização, desde o momento em que foi formada, ainda nos termos da demarcação de uma área indígena em Altamira: 
“E a gente sempre, antes da associação, a gente já pensava num bairro indígena, que é o Independente II, que se chama Onça, outros chamam Missão (...). A gente fez até um documento e encaminhamos pra Brasília, e fizemos uma reunião grande, com cento e poucos índios no bairro, lá do Independente II, da Missão, pra gente pegar assinatura e encaminharmos pra Brasília pedindo um antropólogo pra vir estudar essa área, pra fazer um bairro indígena. Veio a Maria Elisa, a Leila (...). Então o que a gente fez, a gente foi medir: pegamos o Paulinho, a tia Maria e entramos numa voadeira e dizíamos assim 'até onde era aquela roça de vocês, onde foi enterrado índio tal?' Subimos o Xingu até a Praia Grande, batemos o GPS e voltamos pela estrado do aeroporto; nós fomos até o presídio, e do presídio nós fomos até a beira do rio (...); pega essa parte do Praia Clube, essa área todinha, até aqui o São Sebastião (...). Quando a gente fez isso a gente ficou muito animado desse bairro. Era entre 1998, 99... E aí quando a gente fez o documento e encaminhou pra FUNAI de Brasília, veio a resposta, que não dava pra ser feito o bairro indígena devido que tem muita gente dentro que não é indígena. Você pensa? Desmontar um bairro, tirar as pessoas... Aí eles querem ir pra roça, mas já não dá mais (...). A FUNAI de Brasília, quando encaminhou essa Maria Elisa e a Leila, quando a gente fez o trabalho a gente deu de cara assim que eles disseram: 'Elza é impossivel, só pra tirar o Independente I e o III é muito impossível'. E aí começou aquela perseguição, os fazendeiros, as pessoas que tem prédios começaram a me pressionar. Daí eu pensei: 'gente eu vou largar mão disso, porque eu não tenho ninguém pra dar um amparo, eu estou dando minha vida e amanhã o cara vai me acerta em qualquer canto, e aí?' Aí depois que a gente encaminhou pra FUNAI de Brasília ela não respondeu que não podia fazer, disse pra procurar outros meios".

Esse é o mesmo período em que os Kuruaya, principalmente da família de Tereza Kuruaya (mãe de Firmino e Raimunda, que contribuíram para a presente pesquisa) e os Xipaya, todos ligados a família de Elza, estavam envolvidos com a demarcação das Terras Indígenas nos rios Curuá e Iriri. Podemos notar que nesse momento, a reivindicação do movimento indígena estava bastante centrada na questão fundiária, sendo que para os Xipaya e Kuruaya isso significava tanto a reconquista das antigas terras do alto, mas também, como já estavam a muito tempo estabelecidos na cidade, a demarcação de uma área no perímetro urbano. Essa reivindicação era inevitável se pensarmos que todos os Xipaya e Kuruaya mais idosos eram ou foram moradores dos tradicionais bairros indígenas de Altamira (Muquiço e Missão), na porção ao sul do centro da cidade, que foi delimitada para demarcação pelos 
anciões, como descrito no relato de Elza Xipaya. No movimento citadino nascente essa demanda estava profundamente ligada ao reconhecimento da relação antiga desses povos com Altamira, trazida pelas lembranças do tempo em que viviam como numa aldeia em pleno perímetro urbano da cidade. Essa mobilização deu o tom de como a questão fundiária para os citadinos se conformaria enquanto direito à cidade, subvertendo a lógica da proteção constitucional aos povos indígenas que tende a ser traduzida, por meio do órgão indigenista oficial, apenas como um problema e demarcação de suas terras. Ao mesmo tempo, já se delineavam alguns indícios de quais seriam os problemas inerentes a essa mobilização política, como quando a interlocutora fala das pressões sofridas remete-se não apenas a um quadro de enfrentamento, típico os processos de demarcação de terra, mas que coloca também o problema da coabitação intensiva com os não indígenas, um aspecto fundamental a organização Xipaya e Kuruaya:

"Foi aí que a gente começou a entrar no lado de Belo Monte, que foi cadastro, o primeiro cadastro tinha várias opções... (...). Foi isso que entrou no PBA indígena, o bairro indígena. Aí quando veio esse cadastro, já o EIA/RIMA, deu pra colocar pro índios qual era a opção, a casa, o novo assentamento, o bairro indígena, ou dinheiro. No momento a maioria pensou no bairro indígena. Depois de feito o primeiro cadastro, foi levado... Daí na última discussão que teve com o IBAMA, eles disseram que não dava pra fazer um bairro só pros indígenas. $O$ PBA não pode ser diferenciado, dos índios citadinos, porque já está tudo misturado... Só que se eu tivesse o entendimento que tenho hoje do PBA eu tinha dito que dava, porque não é só Altamira que tem um bairro (indígena) dentro da cidade. Você vê no Mato Grosso, os Terena tem um bairro que ganharam e está lá dentro (...). Eu não entendia bem... Porque até hoje não tem esse que diz que entendeu o PBA, porque até hoje ninguém entendeu! Algumas coisa eu entendo, mas é muita burocracia, palavra diferente, fala o português claro que eu entendo! Depois veio o segundo cadastro que foi 2012, daí já tinha uma orientação pra gente, 'se for ser um bairro indígena, vai ser um patrimônio da união, a FUNAI vai assumir, vai ser um patrimônio da união'. Dai quem pulou fora já foi eu mesmo, eu pensei: 'poxa, tenho minha casa, trabalhei feito uma condenada pra ganhar minha casa, daí vou lá e dou de patrimônio da união!' Dai eu dizia: 'tem três opções, tem o bairro indígena, tem o cartão, e tem o dinheiro. O bairro indígena é assim você tem sua casa mas ela é um patrimônio da união, você não pode vender, você vai ter ficar ali pro resto da vida'. Quando a gente finalizou o cadastro, $100 \%$ estava querendo cartão, ou ir pro assentamento”. 
Com os estudos ambientais de Belo Monte a questão do bairro indígena volta a tona a partir o levantamento feito que indicou o desejo dos citadinos de habitar um bairro em que pudessem morar com os parentes, o assim considerado bairro indígena. Assim que esse desejo foi levantado e apresentado houve uma grande discussão com os órgãos ambiental e indigenista sobre as possibilidades e os problemas para criação de um bairro desse tipo. A própria indefinição das contrapartidas, se haveria ações específicas para os indígenas da cidade com um PBA específico, corroborava para que o problema levantado não fosse discutido amplamente com a população indígena de Altamira e levado adiante. Contudo, a orientação durante o recadastramento, como informa a interlocutora, indicava que esse bairro teria a forma legal de uma Terra Indígena, ou seja, uma área sob domínio a União. A rejeição absoluta dessa proposta revela como a questão fundiária para os indígenas citadinos perpassa por uma outra lógica de reparação e reconhecimento de direitos, um vez que a organização sociocultural desses grupos corresponde a modos específicos de habitar a cidade, em que a rigidez da forma institucional de demarcação não é capaz de abarcar. Com essa determinação o abandono da proposta do bairro parecia inevitável até quando começaram os processos de negociação com a população relocada por Belo Monte. Nesse momento as famílias passaram a expressar a insatisfação com muitos aspectos dos novos reassentamentos, como a distância do centro a cidade, por exemplo ${ }^{90}$. Dessa conjuntura se formou o movimento pelo reassentamento do Pedral, encabeçado pelas associações INKURI e Kirinapã, uma nova área para a construção de um bairro para os realocados por Belo Monte. No final do ano de 2013 foi retomada a discussão sobre o bairro indígena por meio da reivindicação levada à Brasília pelas lideranças Claudio Kuruaya e Xipainha, fundamental para determinação de uma portaria da FUNAI que exigiu a consulta à população indígena realocada. Assim se expressou Claudio Kuruaya durante a abertura dessa reunião realizada no início de 2014:

"Nós estamos na luta pra conseguir esse momento, independente de etnia, Xipaya, Kuruaya ou Juruna... E na realidade, essa reunião era pra ter acontecido há dois anos, essa reunião onde a gente poderia tirar dúvidas, a gente tinha que ser consultado sobre a questão do projeto da Norte Energia, pescadores também. Sobre o padrão das casas oferecidos pela Norte Energia, porque eu sempre venho batendo no seguinte: pra gente pegar uma coisa melhor. Que a Norte Energia não está dando nada pra nós. Ela está tirando, obrigando você sair do que é seu, pra simplesmente querer empurrar umas casinhas dessas de concreto... ${ }^{90}$ Todos os assentamentos a estão à oeste do centro e Altamira, após a Rodovia Transamazônica, na parte alta e
Altamira, distante o rio Xingu. 
Então nós estamos trabalhando aqui pra gente construir uma casa, construída de tijolo, a exemplo dos índios da aldeia. Os Xikrin conseguiram ganhar (...). Onde a presidente da FUNAI garantiu: 'Sim Cláudio, há possibilidade sim das casas de vocês serem construídas de tijolo, de cimento de bloco'. E a gente vem discutindo também sobre a questão da área. Existe muita gente que vive da atividade de pesca, que tem barco, tem seu motor, não só isso. Porque o Kuruaya, o Xipaya e o Juruna eles já eram acostumados a morar na beira do rio. Altamira ela foi constituída através dessas etnias, onde você vai sair as vezes da beiro do rio ou, não de perto da beira do rio ali na Invasão dos Padres, querem jogar pro Jatobá, dificultando essas atividades de pesca. Porque vamos supor, têm pessoas ali que quando chega com o barco, com sua tralha de pesca, ele paga o que? Vinte, quinze reais pra ir pra Invasão dos Padres. E lá pro Jatobá vai ser no mínimo oitenta reais, ou cem reais de frete de pesca. Isso aí esse pessoal não levou em consideração em nenhum momento (...). Mas a gente tem que lembrar que nós temos sim o poder de decisão. Nós temos que lembrar que não é o que eles querem. Por que o índios da aldeia vem se revoltando também com o pessoal da Norte Energia? Por causa de descumprimento, que eles falam uma coisa, e depois passa dois ou três meses do ano e ele já chega na tua casa falando outra (...). Então pessoal vamos pensar, vamos lutar por uma coisa melhor. Não precisa se desesperar não, deixa os brancos irem lá pro deles. Mas vamos lutar por uma coisa melhor, porque nós não temos que pensar no momento, nós temos que pensar no futuro dos nossos filhos dos nossos netos. 'Pô o rio ta enchendo'. Não pera aí, só porque vai passar mais um inverno ali, talvez um inverno ali na Invasão dos Padres, não precisa se desesperar. Então vamos acreditar e confiar com fé em Deus, porque hoje isso aqui que está acontecendo aqui pra nós, esse momento específico onde você vai tirar sua opinião. Se tu disser: 'eu to achando essas casas realmente pequenas, vamos trabalhar em cima dum modelo de uma casa oferecida pela Norte Energia que é uma casa de $78 \mathrm{~m}^{2}$, que está dentro do projeto, dentro da proposta deles. Três modelos de casa, primeiro: um de $60 \mathrm{~m}^{2}$, outro de $69 \mathrm{~m}^{2}$ e o último de $78 \mathrm{~m}^{2}$. Vamos trabalhar se ela não fizer uma casa de $78 \mathrm{~m}^{2}$, mas que ela faça uma de $69 \mathrm{~m}^{2}$, porque lá pros índios dos Xikrin eles ofereceram uma casa de $64 \mathrm{~m}^{2}$, maior do que a do pessoal da cidade. Porque tem casa aqui dos índios citadinos que é grande. Se tu for lá no reassentamento da Norte Energia, se tu ver essas casas são pequenas. Então nós estamos sim trabalhando, numa proposta melhor, numa área plana. Como o Brasil (representante da FUNAI Altamira) colocou aqui, nessa área vai ter projetos dos índios citadinos. Agora a partir do dia 15, do dia 16 a gente vai ter sim uma reunião diretamente em Brasília com a presidente da FUNAI pra gente discutir a questão dos projetos de atividades produtivas, de escola, de posto de saúde, tudo tem que ter nesse 
reassentamento, fortalecimento institucional... Então isso aí é importante pra nós. Que a gente não pode pensar agora no momento, mas sim no futuro dos nossos filhos. Hoje vocês sabem que migrou muita gente de fora pra dentro da nossa cidade. Acidente, morte... Você chega ali pra conseguir pegar uma consulta ali numa ficha num posto médico e... Consegue uma ficha, mas ali pra esperar pra fazer um exame são cinco, seis meses até um ano. Sendo que tem gente de fora que chega tira nossas vagas... E nessa área não, a gente pode ter um posto específico pra nós. Não somos só nós que queremos ir pra lá. Já tem dois bairros pertos, os pescadores brancos também querem ir pra lá, tão junto com a gente (...). Então se fossemos esperar realmente pela Norte Energia, coisa que tinha que acontecer há dois atrás, nunca ia acontecer isso".

O longo trecho é apresentado integralmente pois concentra pontos fundamentais para se compreender a caracterização da reivindicação para criação de um novo reassentamento, na esteira da discussão anterior sobre o bairro indígena, e também como a atuação recente das novas lideranças do movimento indígena citadino se inseriu no horizonte do movimento indígena como um todo nesse período de construção da usina. A começar pela disputa pelo espaço proporcionado pelas contrapartidas de Belo Monte direcionadas aos indígenas, o chamado PBA-CI, que consistiu no foco de ação também da associação INKURI, assim como das posteriormente criadas (como por exemplo a Tubyá e Kuximã, dos Juruna de Altamira e da Volta Grande). Nesse sentido, da forma que na associação Tyoporêmo, muitos dos associados da INKURI estavam insatisfeitos com as outras associações e por isso migraram para a nova associação citadina. É muito interessante notar como essas lideranças nascentes se chocaram com problemas muito parecidos com aqueles vividos pelos pioneiros, como a resistência do reconhecimento como indígenas da cidade por exemplo. Por isso todas as falas supracitadas contém essa reclamação que recaí sobre a denúncia de que seus direitos não estariam sendo respeitados como o dos indígenas aldeados. Essa dificuldade é sempre tematizada entre os interlocutores da pesquisa, sejam ativos ou não no movimento indígena. Assim os indígenas da aldeia são lembrados por terem conquistado a construção de casas de alvenaria, enquanto os citadinos devem ir para os assentamentos com casas de concreto. Embora a defesa do oferecimento de uma casa melhor dentro dos reassentamentos urbanos seja um ponto fundamental na argumentação dessas novas lideranças, é preciso indicar que essa percepção está intimamente ligada não apenas com a desconfiança sobre o material construtivo das casas, como também com relação ao tamanho oferecido, o que no limite 
corresponde à um modo distinto de pensar e viver no espaço, assim como salienta Socorro Arara ao indicar o fato de que os pequenos quartos não levaram em conta a instalação de rede, principal modo de dormir entre os interlocutores. A referência de Claudio aos modelos de diferentes tamanho de casa alude ao período quando a empresa construtora da barragem divulgou que o projeto de reassentamento teria opção de casas de alvenaria com três plantas diferentes, para posteriormente fixar o projeto em apenas um modelo de casa com $63 \mathrm{~m}^{2}$ construídas com placas de concreto ${ }^{91}$. Essas mudanças nos projetos são sempre abordadas nos discursos das lideranças, demonstrando a gravidade dos problemas trazidos com a execução das contrapartidas de Belo Monte, não apenas com descumprimento das promessas feitas, mas também criando um ambiente de expectativas que interfere significativamente na vida das pessoas. Entre essas idas e vindas, como a reclamação da liderança sobre a necessidade da consulta sobre o bairro ter acontecido dois anos antes da então reunião, também manteve-se a polêmica em torno do assentamento ser apenas para os indígenas, condição negada pelo empreendedor e que também reverbera nos órgãos do governo. Sobre esse aspecto as novas lideranças refizeram as estratégias, respondendo não apenas aos questionamentos externos sobre a possibilidade de uma bairro assim, mas mesmo reavaliando de forma a se tornar mais plausível com a situação das famílias indígenas da cidade, todas elas caracterizadas pela presença de entes não indígenas:

“Independente de pescador não índio... A gente quer que o não índio pescador também, com a Colônia de Pesca, o pessoal aí do Seu Lúcio, também queremos junto com a gente aí nessa área perto do rio. Pra não dizer: 'só vai ser um bairro indígena', não, negativo. Eles querem ir pra lá, é melhor pra eles, ele procuraram. Não tem problema, quanto mais gente melhor. Pra não ter aquela diferença, 'ah é um bairro indigena'. Não é um bairro indígena, é uma área situada sim, numa beira do rio que seja uma área melhor, pra aqueles índios que concordam e que querem. O que não quiser não tem problema. Tem o livre arbítrio pessoal pra vocês, pra não dizer: 'Ah, mas nós não somos obrigados a ir pra lá?'. Lógico que não. A gente está fazendo uma proposta melhor. Que as nossas casas sejam construídas de tijolo, num padrão maior, pra que a gente tenha direito nos benefícios dos projetos de índio citadino".

91 Sobre essa alteração nos projeto das casas: http://www.socioambiental.org/pt-br/noticiassocioambientais/semana-comeca-com-protestos-no-canteiro-de-obras-de-belo-monte-e-em 
Embora a proposta do bairro contemple um grande número de pessoas é preciso lembrar as muitas diferenças que compõem o cenário indígena na cidade, não apenas com relação a diversidade étnica dos povos citadinos, mas mesmo as divergências entre as associações que demostram como a organização política se mantém atrelada às diferentes redes comunitárias e familiares. Esse foi um dos principais motivos para a criação das novas associações e se mantém como principal ingrediente para as alianças e conflitos, conforme podemos observar no relato de Elza:

“Em 2013, que foi o ano passado que findou, a gente teve um reunião geral com todo mundo, impactado e não impactado e depois a gente encerrou com uma reunião só com os impactados, quem ia pro reassentamento, pra ver a negociação. Aí nessa última visita, que fizemos com os indígenas, fizemos esse cadastro que deu seiscentas e poucas famílias que vão ser realocadas pro assentamento... E a gente não visitou a família do Raimundo que está na área, dai dizem: 'por que visitaram minha tia e não me visitaram? Eu que to na área também'. Ai que tem a polêmica: 'tu não está na área nem de risco e nem vai ser realocado, vai ficar na sua casa, normal'; 'não mais eu quero ir pra lá', 'tu quer ir? Mas não é um bairro indígena...'. Bom é essa briga do Cláudio que está hoje, quer um setor que nem o Pedral (...). Agora tem que ver, quantos índios vão ser impactados? Ele está com trezentos e poucas assinaturas de índios impactados diretamente... Mas vão ser feitas casas só pra esses que vão sair? Que nem os pescadores indígenas, eles querem o assentamento do Pedral. Tudo bem eu concordo, agora o que eu não concordo é tirar uma pessoa que não tem necessidade de sair pra ir pra lá. Só por que vai ficar fora do laço de parentesco? Altamira é tão grande, a gente tem tanto parente não é todo dia que eu vou ficar na tua porta, que eu tenho que me comunicar contigo".

Ainda que a interlocutora concorde com um bairro que não seja exclusivamente indígena põe em questão esse fato uma vez que foi parte integrante do movimento que lutou pela criação de uma bairro dos indígenas de Altamira. Agora mais distante do protagonismo nessa nova mobilização, participa atuando como servidora da FUNAI e também como indígena realocada. Nesse sentido é interessante indicar que optou por uma casa em outro reassentamento oferecido, local no qual já vem morando. Trabalhando diretamente com a questão das famílias realocadas Elza Xipaya informa como as expectativas sobre novo bairro recuperam a ideia contida nos primórdios da discussão sobre o bairro indígena, quando as 
pessoas estavam interessadas em construir o bairro baseado na proteção das relações de parentesco. Entender o legítimo questionamento de Elza Xipaya sobre essa reivindicação no atual contexto da realocação das famílias é antes um exercício de compreensão da importância desse valor, do que a verificação de seu abandono pela interlocutora. Isso ocorre mais pelo modo como foram construídas as alianças atuais em torno da criação do bairro, do que realmente pela desvalorização dos chamados "laços de parentesco". Ao afirmar essa posição Elza Xipaya antes reitera a importância dessa vinculação do parentesco, assim como o fez anteriormente quando falava das genealogias, contudo corroborando com a ideia de que esse parentesco é essencialmente construído como aliança, declarando o valor moldável do pertencimento e da identificação, ou seja como fundamentalmente político.

A despeito das intrigas internas e das adversidades externas o movimento indígena citadino continua lutando, agora para serem melhor atendidos pelos projetos de compensação e mitigação dos impactos da obra. O discurso de Claudio salienta que buscam acima de tudo esse melhor quando reivindicam esse novo local de reassentamento. O que é esse melhor torna-se o ponto fundamental que entre em tensão com todas as interferências trazidas por Belo Monte, sejam elas bem ou mal intencionadas. Um conflito inerente, pois os meios firmados para a comunicação entre os indígenas de um lado e o empreendimento do outro, mediados pela atuação trôpega dos órgãos reguladores, são a maior parte do tempo incompreensíveis por uma das partes, a medida em que veiculam concepções e práticas distintas sobre o que é e como devem ser feitas as propostas políticas de bem comum. Ou seja, trata-se de um conflito entre duas partes não apenas com interesses distintos e que são obrigadas a conversar, mas acima de tudo com visões de mundo e modos de fazer diferentes que podem se ajustar apenas se alguns dos lados ceder. E dessa equação em aberto não existiram muitos bons resultados como exemplos, como nos contam as histórias de ocupação dessa região, seja durante o período da borracha e ou da Rodovia Transamazônica, em que fica evidente qual lado somou as maiores baixas. Hoje existe um outro contexto, que se refere aos avanços do estado democrático de direito reconhecido pela Constituição de 1988. Contudo é preciso reconhecer como esse arranjo permitido pelas instituições democráticas ainda está em pleno exercício de aprimoramento, o que explica muito da desorganização e das dificuldades da produção de consensos, além do modo truculento que permanece nos muitos 
processos decisórios sobre essa polêmica obra. Os exemplos da relação do movimento indígena citadino com a construção de Belo Monte falam dessa distância cosmopolítica, mencionada durante o início do capítulo, que purifica de um lado a política institucional oficial, impessoal e burocrática, e do outro a militância comunitária, com seus modos oficiosos, personalistas e baseados em relações de parentesco e amizade, que impede que se assuma o quanto ambas estão insuperavelmente intricadas.

Compreender cada justificativa indicada pelos interlocutores que participaram da referida oficina sobre a construção do novo bairro, dispostas entre o desejo por melhores condições de habitação e infraestrutura urbana e a necessidade de se manterem perto do rio, dos parentes e dos conhecidos, nos ajuda a aceitar essa composição como a legítima expressão do modo de vida dessas pessoas enquanto indígenas. Ao mesmo tempo, o bairro do Pedral é uma proposta que provoca o que é legitimamente indígena pois é mais uma recriação, conquistada com o sofrimento e a persistência desses Xipaya, Kuruaya, Juruna, Arara, cearenses, altamirenses, etc., que pretende preservar, atualizar e fortalecer seus valores de vida diante dos novos desafios impostos. Assim descreve Claudio Kuruaya sobre os motivos do bairro:

“Então, eu quero colocar aqui também, por exemplo, a questão dos laços de parentesco, é muito importante o pessoal registrar a questão dos laços de parentesco. Não pode haver dissolução dos laços de parentesco, a exemplo da nossa rua, no bairro Independente II, que algumas famílias vão sair, outras vão ficar, então a gente quer ir junto pra lá sim, pro assentamento. Vai se romper, se quebrar um laço de parentesco de quase 50, 60 anos, a exemplo da D. Maria (Yawaidu) ali, da mãe da Bel. Ela chega da aldeia, a Bel é filha dela, leva ela pra ela tirar o dinheiro no banco. Ela vai lá, almoça, janta, tem aquele envolvimento com a família dela. Aí a Bel saí, a Maria vai ficar lá sozinha? 'Rapaz a minha filha foi pra muito longe...' Não pode, isso é um crime! Se vai sair a filha, a mãe tem que sair junto, todo mundo tem que sair junto. A gente está lutando nisso aí, vai dar certo, eu creio. Então pessoal, não vamos desistir, a gente tem um sonho e a gente pode conseguir"

$* * *$

Hoje o sonho de Claudio Kuruaya, e tantos outros indígenas realocados por Belo Monte avança ainda com muitos desafios pelo caminho. Após essa reunião, já no final do ano 
de 2014, a Norte Energia, empresa construtora da barragem, concordou em construir o novo bairro na área chamada Pedral, localizada ao sul de Altamira, uma área próxima ao rio a leste do aeroporto da cidade, na continuação do bairro Independente II. 


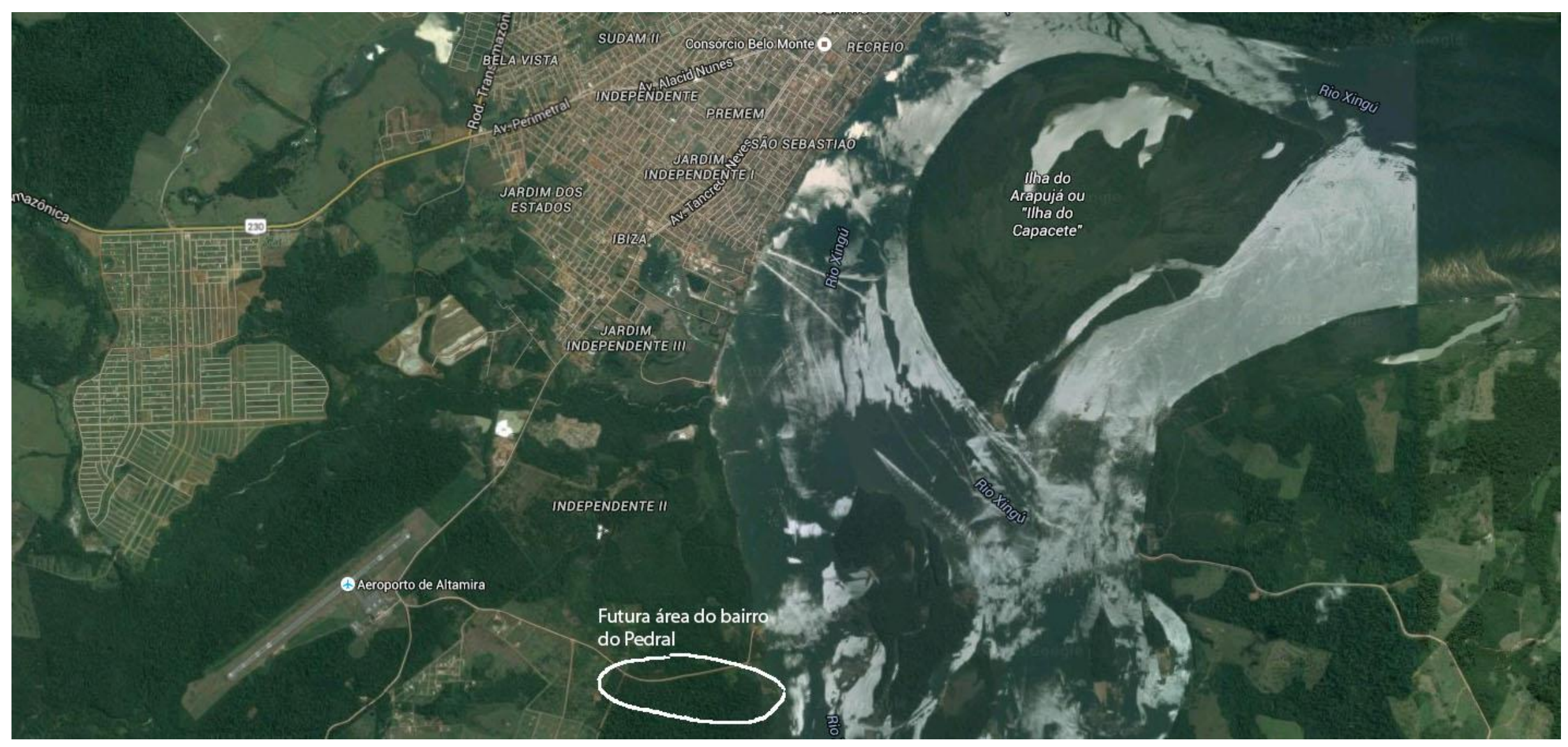

Figura 33 - Área definida para a construção do novo assentamento das famílias indígenas e pescadores não indígenas em Altamira. 
O primeiro desafio para o movimento indígena citadino após a definição do bairro foi manter seguras as famílias que decidiram mudar-se para esse bairro, num momento em que todas as pessoas que habitam as regiões de alagamento, a chamada cota 100, estão sendo obrigadas a se mudar de casa. Para evitar que os indígenas se desesperassem assistindo a saída dos vizinhos e aguardando em locais cada vez mais insalubres e perigosos foi conquistado o direito daqueles que optaram pelo Pedral de mudarem-se temporariamente para os outros assentamentos, enquanto o novo bairro é construído, com previsão de conclusão apenas quando a obra da barragem já estiver pronta. Outra conquista do movimento indígena citadino são as reuniões consultivas que a empresa vem mantendo com a sociedade civil durante a elaboração do projeto e da construção do novo bairro, que permitiram, por exemplo, que o assentamento mantenha preservada áreas verdes próximas, diferente do que vem acontecendo nos outros bairros. Em uma dessas reuniões foi firmado o acordo com a empresa que irá ceder terrenos para as associações citadinas e aldeadas construírem suas sedes no bairro. No bojo desse movimento incorporaram-se também novos atores, como Instituto Socioambiental (ISA), que pretende construir o Centro de Tecnologias e Processamento de Produtos Florestais Não Madeireiros em terreno cedido pela empresa na área do novo bairro. Até julho de 2015 o convulsivo cenário de Altamira após Belo Monte se mantinha com diversas incertezas, contudo já num estágio avançado de construção da obra. A realocação das pessoas das áreas de alagamento, inclusive nos tradicionais bairros indígenas, áreas de moradias dos interlocutores da pesquisa e de seus parentes e conhecidos está quase concluída. 


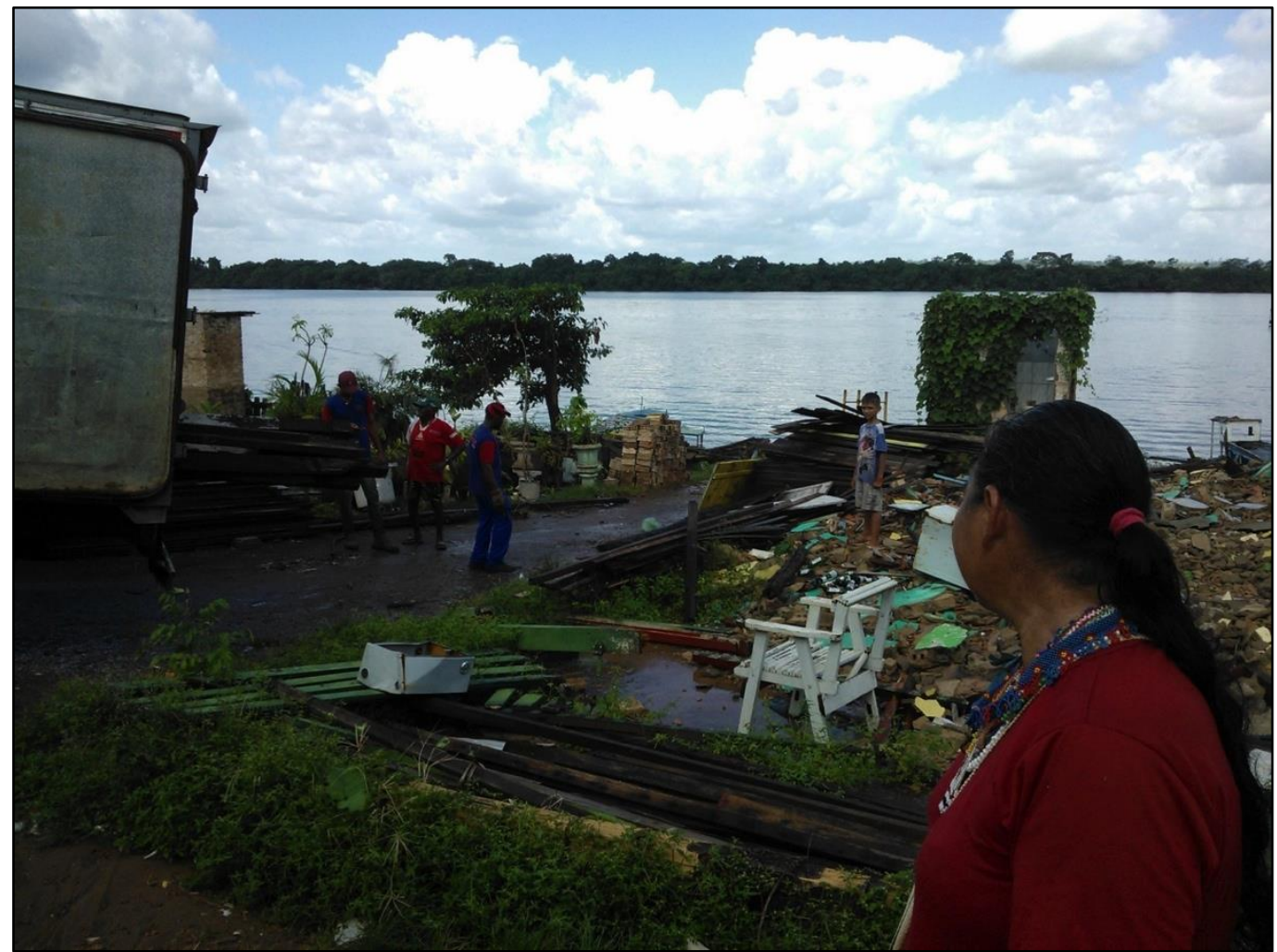

Figura 34 - Casa destruída no bairro São Sebastião (Muquiço) - Altamira, julho de 2015.

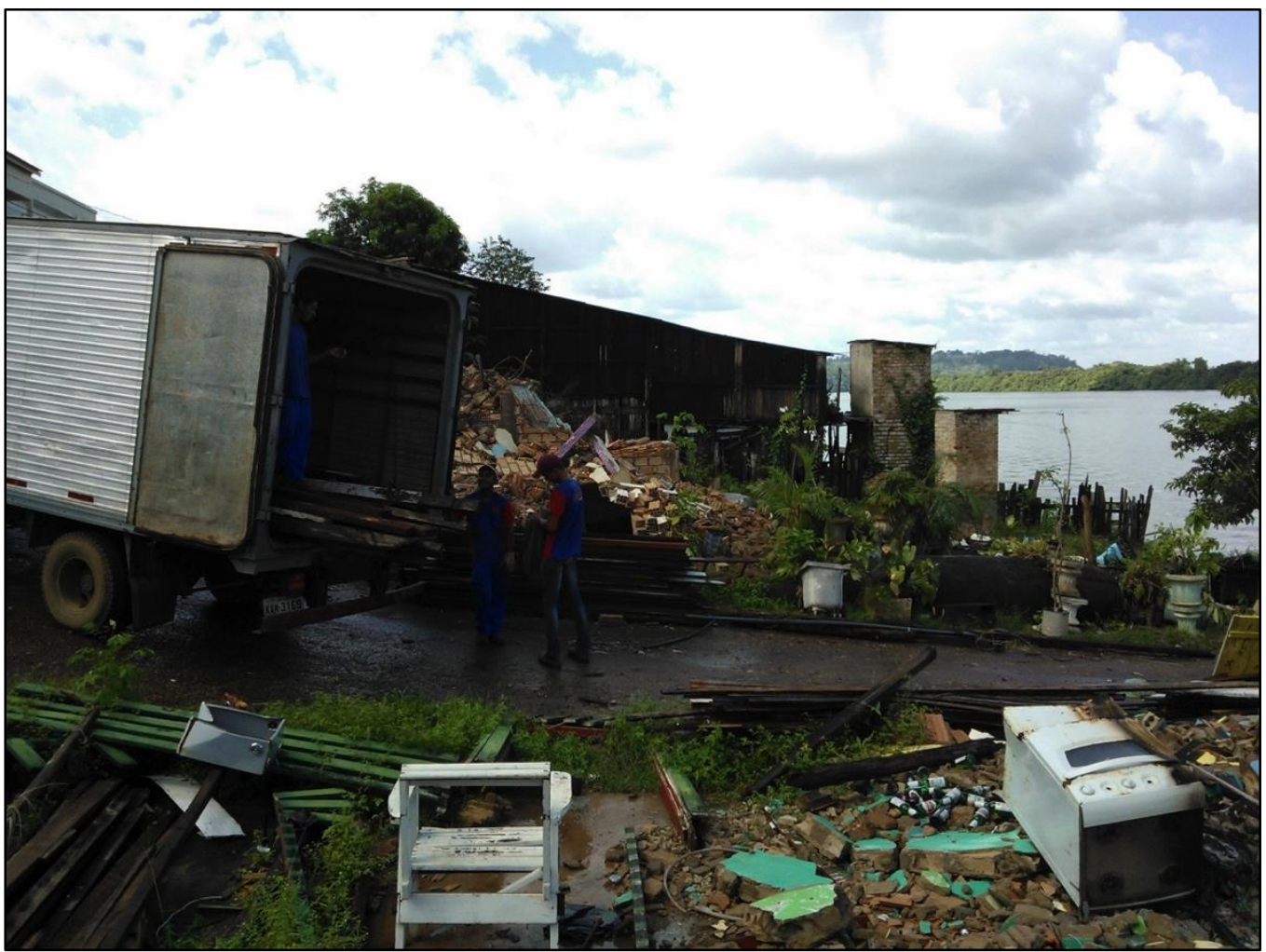

Figura 35 - Mudança de material construtivo aproveitável - bairro São Sebastião (Muquiço) Altamira, julho de 2015. 


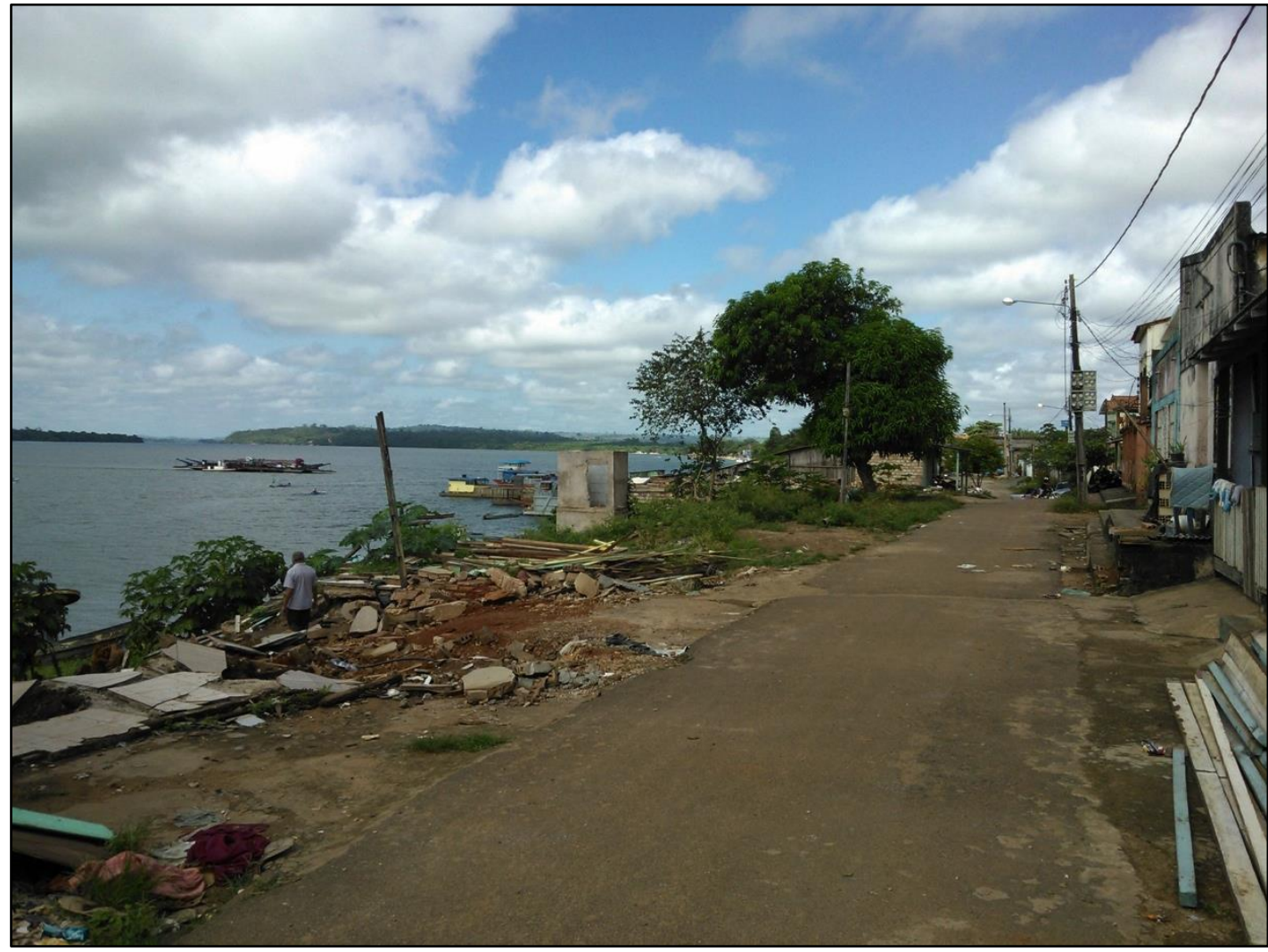

Figura 36 - Bairro São Sebastião (Muquiço) - Altamira, julho de 2015.

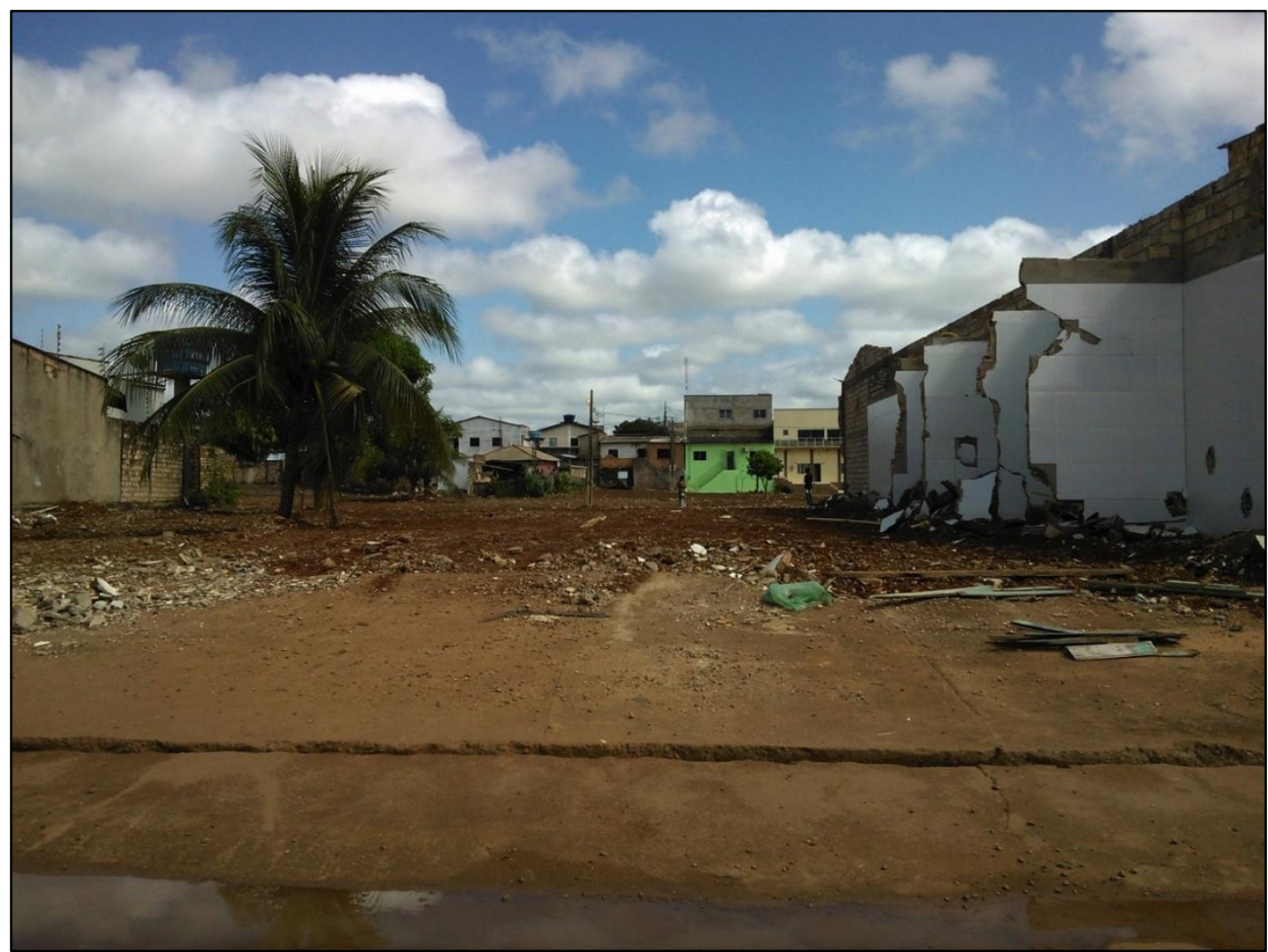

Figura 37 - Av. Cel. José Porfírio no bairro Jd. Independente II (Missão) - Altamira, julho de 2015. 


\title{
5 CONCLUSÃO
}

\begin{abstract}
"O antropólogo faz o que pode, inventando a cultura para tentar conferir um mínimo de ordem e inteligibilidade lá onde a plenitude da vida as dispensa completamente. Nesse sentido, Wagner é provavelmente o primeiro antropólogo a fazer da vida (e não da evolução, história, função, estrutura, cognição...) o referente último do trabalho antropológico". (Goldman, p. 203, 2011).
\end{abstract}

Em se tratando de uma etnografia em tempos conturbados toda reflexão aqui proposta sempre corre o risco da desatualização imediata, tal como parece mover-se o dia-a-dia em Altamira durante a construção da hidrelétrica de Belo Monte. Nesse bojo, qualquer resolução imperiosa sobre quais as direções das questões aventadas pelo trabalho de antropologia será um procedimento arriscado, mas que, não por isso, deve redimir o estudo de ponderações frente aos desafios impostos. Se considerarmos que o alerta é capaz de tangenciar o perigo enunciado, pode-se seguir com algumas indicações sobre a pesquisa que desejam contribuir com certos debates da e sobre a disciplina.

Inicialmente, pretendo retomar brevemente as implicações da pesquisa, destacando alguns momentos decisivos (talvez uma versão contemporânea à velha fuga da rinha galos...) dos quais fui coagente, indicados ao longo da dissertação. Tratam-se das atividades ligadas ao trabalho de valorização do patrimônio cultural dos indígenas citadinos no contexto do PBACI, referido no Capítulo 4, e que estiveram presente em diversos momentos da dissertação, que aproveitou muitos dos dados colhidos durante essas atividades. Mais do que fazer qualquer inquisição sobre a posição ocupada em campo em relação aos sujeitos da pesquisa (visto que essa crítica mantém-se cabível à qualquer trabalho antropológico) planejo demonstrar como meu engajamento no trabalho correndo em paralelo à pesquisa reforçou uma aproximação tal que me permitiu compartilhar outras propostas antropológicas que não as apenas ligadas aos objetivos da pesquisa. Ao passo que, pesquisa e trabalho sempre mantiveram afinidades mais ou menos diretas. 


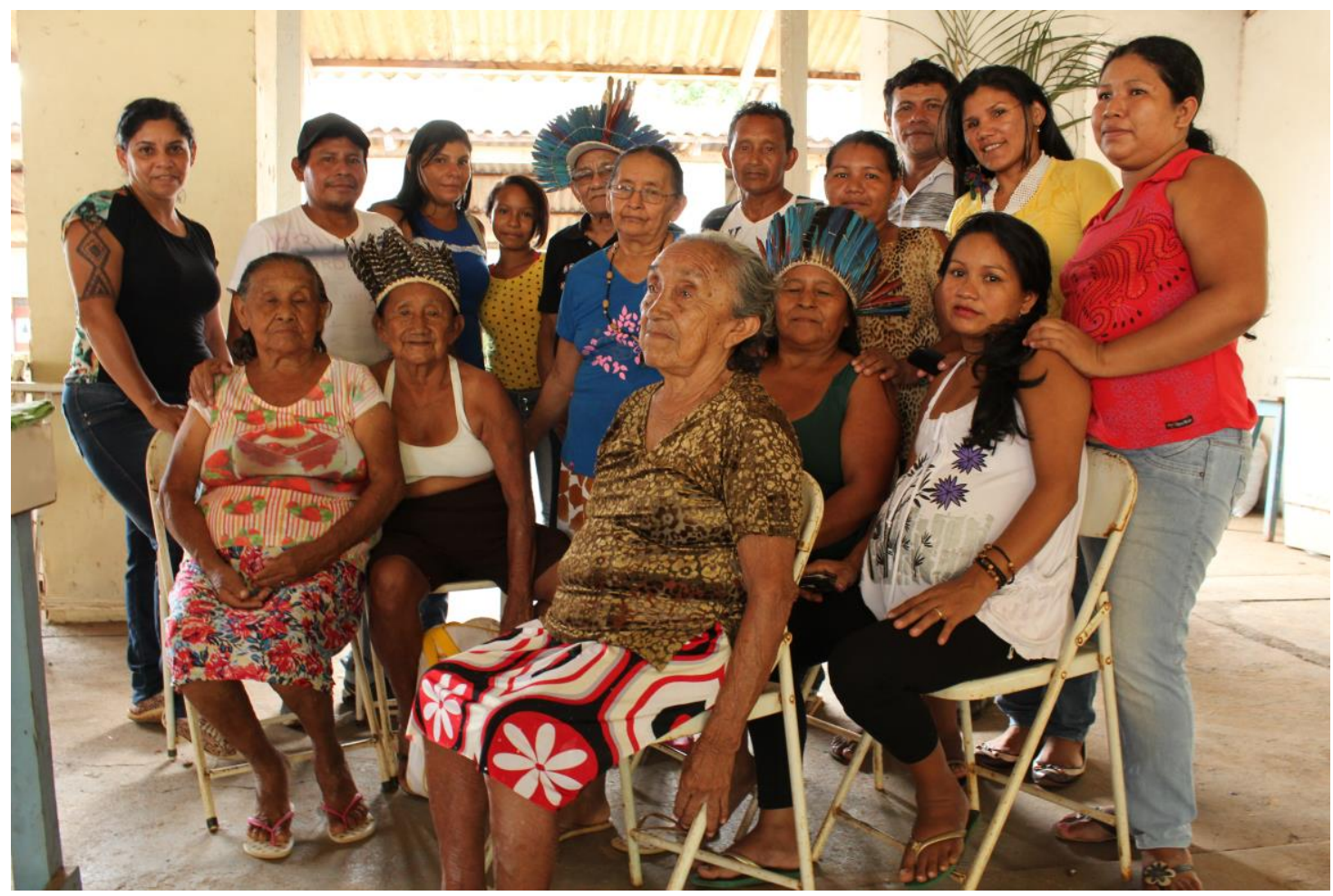

Figura 38 - Os Xipaya e Kuruaya de Altamira durante a Oficina de Saberes e Fazeres - Culinária Indígena Citadina - 2014

A experiência de campo no contexto de Belo Monte é de fato um terreno minado de posicionamentos e engajamentos, dos quais, por sua vez, é impossível de se isentar. Essas posições tem implicações não apenas sobre o resultado analítico mas são, acima de tudo, éticas. O horizonte de princípios entre finalidade da pesquisa e do trabalho norteou integralmente as ações desenvolvidas em campo, no sentido da possibilidade de propor contrapartidas "privilegiadas" da pesquisa, pois viabilizavam atividades que exigiam recursos impensáveis para as condições de pesquisa no ambiente regular. As aspas no privilégio obviamente se referem ao contexto um tanto quanto adverso de Altamira, no qual muitas vezes a pactuação com os interlocutores, principalmente aqueles do movimento indígena citadino, era de difícil amarração no seio de um processo de construção de uma obra que, raras exceções, parece não ter ciência de seu momento democrático. Dessa forma cumpre descrever como foram desenvolvidas algumas dessas atividades no âmbito do trabalho de salvaguarda patrimonial. Em primeiro lugar esse deu continuidade ao trabalho de registro audiovisual dos relatos de vida das matriarcas e anciões indígenas de Altamira e da Volta Grande do Xingu. A amplificação da proposta se dava por meio da própria situação encontrada entre os interlocutores e explorada durante a dissertação: das versões de cada 
grupo que no limite, valorizam pais e avós enquanto referências da tradição ancestral para cada família. Assim foi possível caminhar entre muitos lares indígenas da cidade Xipaya e Kuruaya, mas também os Juruna e Arara, que mantém uma ligação bastante íntima com a região da Volta Grande do Xingu, severamente impactada pela obra por se tratar da região de construção de uma das barragens propriamente. Tal como houve a devolução de todo o registro audiovisual aos entrevistados, parte do trabalho também consistiu em apoiar as associações indígenas, seja em oficinas de treinamento e capacitação, ou mesmo diretamente no apoio à criação de novas entidades, como foi lembrado durante a dissertação. Essas ações obrigavam ao posicionamento de determinados "lados", como a etnografia tentou argumentar, em que as disputas ente grupos familiares são o deflagrador elementar. Conquanto, esses lugares do pesquisador também são bastante moduláveis assim como as inconstâncias das alianças entre os atores políticos do movimento indígena; desta forma o trabalho nunca impediu o tráfego entre os diferentes agentes, embora houvesse situações em que era preciso argumentar.

Talvez um dos pontos mais importantes da pesquisa e do trabalho, a compreensão e atuação sobre os processos de fortalecimento cultural com as associações indígenas foram determinantes para a proposição das muitas questões assumidas e revistas pela etnografia e para a organização das ações experimentadas com maior ou menor efetividade pelo trabalho de salvaguarda. Nessa dimensão, foi dada continuidade às oficinas de culinária indígena (organizadas pelo antropólogo Paulo Serpa, com quem dividi os referidos trabalhos) iniciada ainda durante a primeira etapa de trabalho na região no ano de 2012. Motivada pela autoorganização das associações ainda no tempo em que realizavam encontros de celebração, como foi lembrado em vários momentos no relato de Elza Xipaya, essas atividades incorporam saberes e fazeres tradicionais às novas práticas de autoafirmação e valorização que permitem criar novas possibilidades para as experiências indígenas na cidade, permitindo de forma bastante interessante colaborar nesses processo de fortalecimento cultural. A atividade ainda teve de lidar como todo o universo fragmentado e convulsivo ocasionado por Belo Monte e as consequências prejudiciais do Plano Emergencial (assim como lembrou Elza Xipaya, a construção da união entre as associações da cidade é um desafio para essas ações de convergência). Esse é um exemplo de como a proposta de ação e o conhecimento reflexivo caminharam juntos na colaboração e coparticipação nas questões de fortalecimento cultural reivindicadas pelo movimento indígena citadino. Assim, a riqueza das práticas e concepções alimentares ganhou destaques após a elaboração de um boneco editorial sobre o tema da 
culinária indígena citadina de Altamira e ribeirinha da Volta Grande do Xingu, "Comida de Caboco", que foi ainda avaliado e comentado pelos representantes e associações indígenas os quais ficarão com os direitos autorais caso o livro seja publicado. Essa breve descrição das atividades se limita a sugerir alguns apontamentos sobre a implicação dos estudos antropológicos nesses contextos em que o antropólogo, assim como todas aqueles que têm interesse em atuar com os indígenas, são chamados a participar.

Essas sugestões pretendem refletir sobre algumas consequências da provocação de Wagner (2010) de que "trabalho de campo é trabalho no campo", discutindo como os equívocos entre pesquisador e interlocutores conformam-se, também, a partir de propostas de trabalho distintas:

"Meu trabalho pretendia-se criatividade pela criatividade, ou produção pela
produção, empreendido para acrescentar algo ao corpo de conhecimentos
cumulativos que chamamos de 'literatura antropológica'. Seus interesses e
motivações seriam necessariamente obscuros e mesmo enganosos para alguém
que não partilhasse nosso entusiasmo por esse tipo de produção". (WAGNER,
p. 53,2010 ).

Mais uma vez tratando-se de um campo de debate vastíssimo na antropologia, a dissertação se restringe a trazer apenas alguns fragmentos para pensar políticas indígenas e indigenistas a partir dos contextos experienciados pela etnografia. Para tanto, lança mão do artigo de Müller, "Duas décadas de projetos de desenvolvimento entre povos indígenas: da resistência às frentes de expansão do capitalismo nacional à globalização e ambientalismo dos anos 90" (2004: 22), que embora datado pelos desafios encontrados pela autora em 1997, é por isso mesmo bastante interessante para pensar as mudanças e retornos da questão indígena nessa região. Trata-se de uma reflexão sobre a experiência do antropólogo entre os indígenas, com base na extensa vivência da autora com os Asuriní do Xingu, para pensar a contribuição da antropologia sobre os novos projetos de desenvolvimento que se formavam em torno da ideia de sustentabilidade. Müller então retoma o contexto de inserção de sua geração no campo da etnologia indígena, destacando o momento em que o desenvolvimento econômico nos estados amazônicos era parte fundamental dos projetos de integração nacional do governo militar:

"A demarcação destas (Terra Indígenas) e projetos econômicos para prover as
necessidades advindas do contato com as frentes de atração do órgão oficial
passaram a ser assuntos que tínhamos necessariamente que abordar para 
propor ações com objetivos, para nós, claros, de ordem eminentemente prática e de intervenção salvacionista, pois capitalismo selvagem, autonomia de povo indígena e plurinacionalismo, ou seja, sua sobrevivência física e cultural, não andariam e nunca andaram juntos. Projetos de assistência à saúde compunham também um campo desta antropologia aplicada, baseada fundamentalmente, e nisso fomos exemplares, no profundo conhecimento e continuada convivência junto às comunidades que se tornaram temas de nossas teses acadêmicas". (MÜLLER, p. 182, 2004).

Durante esse período Müller fala das intervenções propositivas que tentavam resistir aos planos hegemônicos de "pasteurização da diversidade na Amazônia", implementados pelos órgãos de estado e principalmente por meio dos projetos econômicos, como estímulo à abertura de plantações de arroz e de cacau, por exemplo, "que tratavam os indígenas da mesma forma que os migrantes do sul do país”. Os projetos de integração, como lembra Carneiro da Cunha (2014), eram imbuídos do ímpeto em "desenvolver" os indígenas, transformando qualquer política de contato em assimilação, muitas vezes forçada. Esse desafio que assolava antropólogos e indígenas durante o período, implicava a união de ambos não apenas em torno da demarcação das terras e controle do avanço de doenças, como forma de sobrevivência física, segundo Müller, como também já acenava para a criação de condições econômicas dos Asuriní, um povo de recente contato, mas cujas consequências tardias do contato já se projetavam. Avançando no tempo, a autora demonstra como foi se desenvolvendo a situação dos Asuriní após o momento em que os projetos de integração nacional haviam deixado seus resquícios para traz, tornando os Asuriní dependentes de bens de consumo que passaram a adquirir trocando por artefatos destinados exclusivamente para isso.

Encontrando um novo cenário depois de duas décadas da ocupação sistemática da região pelos projetos de colonização, Müller irá redefinir os princípios de atuação dessa etnologia que havia se formado no decurso dos perigos do avanço civilizatório sobre os grupos de recém-contato durante os anos de 1970 na Amazônia. Essa reflexão já é feita após o contexto da constituinte democrática, depois das tentativas do barramento de Kararaô, quando o avanço dos empreendimentos de grande impacto na região pareciam ficar como "vestígios arqueológicos que algum dia irão ilustrar o delírio dos militares "pra frente Brasil" para a ocupação da Amazônia” (Müller, 2004). Verdade seja dita, hoje é necessário rever esse quadro, pois as lutas do movimento indígena e socioambientalista que conquistaram a mudança do projeto Kararâ̂, alterado para reduzir seus impactos - como foi lembrado durante 
a dissertação - se encaminharam para a construção da terceira maior barragem do mundo, Belo Monte. Hoje o horizonte de atuação da etnologia na Amazônia chama os antropólogos a se engajar em novos desafios impostos pelo avanço do desenvolvimento econômico na região, que pretende implementar projetos mais parecidos com aqueles planejados durante os governos militares, mas com uma conjuntura política, institucional e militante, bastante alterada. Parte dessa alteração, correspondente ao movimento indígena, reflete a mobilização crescente em torno das causas ambientais, fator já indicado no texto por Müller, que discute projetos de ecoturismo e turismo cultural nas terras indígenas como alternativa à necessidade de se enfrentar a dependência econômica desses grupos:

"A reflexão crítica e ideológica é necessária sim, desde que acompanhada de
propostas alternativas de desenvolvimento no processo de contato, uma vez
que, a se manter a situação de penúria e ausência de formas adequadas para
este tipo de etnodesenvolvimento, os Asuriní estarão à mercê de madeireiros e
garimpeiros que lhes oferecerão, sem a menor dúvida, as suas próprias
alternativas". (MÜLLER, p. 187, 2004).

Diante de dilemas que marcaram a antropologia desde seu nascimento, essas novas configurações citadas remetem às questões já amplamente discutidas pelas ditas antropologias pós-modernas, talvez mais contundentemente por aqueles que preferem o título de póscolonial, grosso modo, mostrando como a posição dos sujeitos da pesquisa se tornava bastante ativa diante das intenções do antropólogo. A importante contribuição de Albert (1995) pode ser depreendida da passagem de Müller, pois aqui se trata de uma antropologia que supera o momento em que era aplicada e não fazia sua autocrítica, mas condena a exclusiva autocrítica: deve ser então implicada, característica que pode ser lida dos argumentos que relacionam o profundo e abrangente estudo dos grupos indígenas à capacidade propositiva do antropólogo. Isso posto, podemos prosseguir a reflexão de Müller marcando o elo que permite retomar o artigo diante dos novos desafios impostos que foram discutidos pela etnografia.

Na Introdução de Políticas culturais e povos indígenas (2014) Carneiro da Cunha afirma que duas dimensões de intervenção política do Estado e de outras organizações indigenistas ganharam destaque ao longo do tempo na configuração de políticas culturais: a escolarização multicultural e a patrimonialização de expressões tradicionais. Essa percepção da autora alude a inúmeros exemplos etnográficos que abordam o modo como o indígenas lidam com essas políticas, muitas vezes incompatíveis com as aspirações dos principais envolvidos, os próprios índios. A despeito das inconsistências dessas políticas, criadas por 
inúmeras dificuldades que vão da operação à concepção, é possível determinar que grande parte delas nasce de uma resposta ao quadro de ataque ou destruição do que se convencionou chamar de "cultura tradicional". Embora essa preocupação tenha se materializado em propostas pouco satisfatórias - elevando "fiapos de cultura" (Carneiro da Cunha apud Azevedo, 2014) como se representassem uma cultura ancestral preservada - ela guarda também potências imprevisíveis, no sentido de permitir outras possibilidades entre os indígenas, das quais a antropologia tem papel fundamental.

Seguindo os argumentos de Müller sobre os Asuriní, a autora apresenta a tentativa de um projeto de estudo e intervenção sobre a arte gráfica Asuriní que visava a compreensão das transformações de artefatos após a introdução de seu comércio com a FUNAI. Descrevendo mudanças do suporte de veiculação dos desenhos que mantinham as mesmas regras estéticas e morfológicas, a autora infere "a relação entre formas de resistência cultural e reelaboração simbólica através das manifestações artísticas” (Müller, 2004). Partindo dessa constatação aventada ainda nos anos de 1980, Müller reaborda a questão já nos anos de 1990 quando destaca o aumento das relações interétnicas, com outros indígenas e com não indígenas, mas ao mesmo tempo demonstra como essas transformações são internalizadas pelos Asuriní por meio dos rituais como espaços de resistência e reelaboração. Sendo assim, conclui que se nos anos de 1970 o desafio passava pela a "interrelação entre economia, território e situação sanitária como o nexo ecológico sobre o qual se exercem as pressões adaptativas do contato", hoje deve-se acrescentar a esse nexo, visto as transformações observadas, outro termo, o da reprodução cultural: "Hoje a autogestão é o ponto de partida para qualquer programa, uma vez que
se superou o risco da extinção (física e perda do território), estas populações
se conscientizaram - através de programas de educação, do surgimento de
organizações indígenas ou da própria experiência de convivência com o
"outro" - o multiculturalismo sendo compreendido talvez muito antes pelos
"nativos" do que pelos colonizadores. A autogestão é o ponto de partida
porque hoje a meta é a efetiva autonomia política dos povos indígenas".
(Müller, p. 201, 2004).

Antevendo os problemas em torno de nossa ideia de multiculturalismo, ao falar sobre outros modos de pensar e fazer relações - próximos aos aventados pela ideia de mistura Xipaya e Kuruaya - o argumento de Müller repõe perfeitamente como os indígenas observam outros perigos dessas situações de contato, e por isso outras possibilidades, cujo sentido 
político poderíamos traduzir melhor como a perda e a restituição da autonomia. Mesmo assim esse processo deve ser qualificado, pois, conforme foi alertado, não são simples dispositivos de autoafirmação étnica que permitem que essa autonomia seja preservada ou construída: trata-se de um longo e laborioso trabalho perseverado por essas pessoas ${ }^{92}$, o qual muitas vezes o antropólogo é chamado a colaborar. Os resultados de sua atuação, embora imprevisíveis como qualquer ato criativo, se reportam a sua experiência com os sujeitos da pesquisa e para além dessa, são intimamente relacionados à sensibilidade de sua antropologia. Essa operação permite a Müller concluir:

\begin{abstract}
"Extrema vitalidade cultural em momento de crise, o xamanismo como discurso da resistência, a arte e o ritual como mecanismos de reprodução da sociedade no contexto do contato interétnico são aspectos fundamentais da realidade Asuriní para se avaliar o ecoturismo e o turismo cultural como alternativa viável e adequada ao desenvolvimento deste povo". (Müller, p. 202, 2004).
\end{abstract}

Discutindo com os impasses causados pelo comércio de artefatos Asuriní de então, a autora propõe alternativas à medida que observa as transformações na sociedade Asuriní e seu entorno. Relembrando que se trata de um artigo datado, é possível que a solução debatida naquele momento não seja mais possível hoje; contudo a consistência da antropologia que a defende mantém-se sólida. Será preciso perguntar como anda o xamanismo e arte entre os Asuriní, mas mesmo sem saber, recupero a percepção de Müller para desenvolver a discussão final sobre a experiência etnográfica da dissertação.

As possibilidades do xamanismo como resistência e a arte e ritual como modo de reprodução servem de inspiração para pensar como devem se articular esses espaços de proposição entre sujeitos e pesquisador. $O$ intenso contato que perdura para os grupos indígenas citadinos de Altamira tem mais afinidades com a experiência Asuriní do que se pode supor. Retomo a ideia de fortalecimento cultural, para falar da força das atividades de preservação, promoção e divulgação da culinária indígena na cidade ${ }^{93}$, por exemplo, reivindicada em muitos momentos pelos interlocutores da pesquisa como resistência; mas

92 Eloy e Ventura (CARNEIRO DA CUNHA \& CESARINO, 2014) sugerem que os movimentos de reapropriação da educação entre os Terena consolidam-se após sua longa experiência com a escolarização, permitindo a esses proposições mais consistentes sobre uma escolaridade diferenciada, por exemplo.

93 Carneiro da Cunha (2014) ressalta a importância da preservação da agrobiodiversidade: "Essa diversidade é elemento central da segurança alimentar do mundo e faz parte de uma modernidade avançada, aquela que não privilegia simplesmente a produtividade" (CARNEIRO DA CUNHA \& CESARINO, p. 19, 2014). 
também reestabeleço o valor da ideia de resgate cultural, noção também amplamente veiculada pelos interlocutores, mas que já não deve ser confundida com métodos salvacionistas, do modo quando a antropologia previa o desaparecimento de certas culturas em perigo. Ambos os termos dialogam com a ideia de etnicidade como meio para reivindicação de direitos, mas essa face tende a reduzir os modos nativos que as formulam. Para rever mais de perto essas ideias, por meio da atuação do etnógrafo, recupero experiências de resgate que, formuladas dessa maneira pelos interlocutores, são apresentadas em termos de tradição e costumes perdidos, mas contém igualmente outras motivações e possíveis efeitos, para além do formato instrumental político exigido. A atividade nomeada de "Intercâmbio Cultural" - que foi rapidamente lembrada ao final do Capítulo 3 - foi uma proposta de experiência de interação entre grupos indígenas diferentes a fim de terem contato com formas distintas de atuação em questões que afetam ambos. No caso dos indígenas citadinos, consistiu em duas experiências diferentes: viagem à Itaituba de lideranças Kuruaya para contato com os Munduruku da Praia do Mangue, Praia do Índio e aldeia Sawré do Km 43; e viagem ao Parque Indígena do Xingu dos Juruna da TI Paquiçamba, do Km 17 e citadinos em visita às aldeias Yudjá Aribaru e Tuba-tuba, e também visita dos Yudjá à TI Paquiçamba.

Valendo por si só uma descrição etnográfica, resumo alguns pontos das atividades a fim de apresentar reflexões sobre as propostas de colaboração/intervenção. Inicialmente as viagens foram definidas nos seguintes termos pelos interlocutores: serviriam para reencontrar aspectos perdidos da cultura Kuruaya e Juruna ${ }^{94}$ por meio do parentesco entre os grupos; tal observação se ancora na ciência dos interlocutores sobre a semelhança da língua Kuruaya com a Munduruku e na ciência de que os Yudjá e os Juruna da Volta Grande do Xingu são o mesmo grupo dividido no início do século XX. O primeiro caso é bastante exemplar para pensar a ideia de resgate para os interlocutores: as intenções de encontrar elementos do que eram os Kuruaya do passado nos Munduruku do presente se defrontaram, durante a experiência, com a reiteração da distinção entre os grupos! Portadora de muitos conhecimentos Kuruaya, Maria Augusta Xipaya, a Xipainha, manteve longas conversas com os caciques Munduruku sobre a semelhança da língua Kuruaya - fazendo verdadeiros jograis de palavras e cantos - ao mesmo tempo em que esteve envolta em discussões sobre a histórica e mítica ligação entre os dois grupos, quando fez questão de lembrar sobre o mito da

\footnotetext{
${ }^{94}$ Lembro aqui que os Xipaya da TI já fazem há algum tempo esse intercâmbio - que proporcionou o encontro de Maria Yawaidu, última falante fluente do Xipaya com os Yudjá, sendo que hoje já se pode encontrar inclusive casamentos entre os grupos.
} 
placenta $^{95}$. Se os Kuruaya afirmam a semelhança da língua, dos antigos artefatos como de mesmo tipo, entre outros, por outro lado, o encontro serviu como marcador de diferenças (até de precedências) que deixaram claro que os Kuruaya não estão interessados em ser Munduruku, como a apressada leitura do resgate poderia incorrer. Mesmo nas conversas sobre os Kayapó, concordantes sobre a visão do inimigo histórico de ambos, foram devidamente identificadas as diferentes consequências das relações de embate para os dois grupos. A ideia do resgate supõe a afinidade entre os interlocutores que já haviam se encontrado nas reuniões do movimento indígena antes da atividade de intercâmbio, e que no momento propunham intensificar a relação por meio da celebração ritual, demarcada então como "encontro de transmissão de saberes", representação que dialoga com as exigências da política cultural externa. Resgate aqui é capacidade de fazer alianças diante desses novos contextos que deflagram desafios semelhantes aos dois grupos, como lembrou a liderança Claudio Kuruaya sobre a barragem prevista no rio Tapajós.

O parentesco entre os Kuruaya e os Munduruku é localizado apenas mítica e linguisticamente, já o vínculo entre os Juruna de Altamira ${ }^{96}$ e os Yudjá do Parque Indígena do Xingu pode ser traçado genealogicamente, como permitiu o encontro entre as sobrinhas netas da aldeia Tuba-tuba no PIX com as netas idosas de Müratu, grande chefe histórico dos Juruna da Volta Grande do Xingu, que é lembrado também pelos Yudjá como pertencendo a uma importante família de pajés da qual alguns se seus irmãos fizeram a migração ao Alto rio Xingu (atual região do PIX). Embora exista essa relação particular entre os grupos, é possível observar a mesma forma de enunciação das motivações dos Juruna de Altamira para a visita aos Yudjá: queriam aprender os costumes e tradições que haviam perdido depois de "misturar com os brancos". O resgate não deixa de ser uma consequência que se deve ser combatida por meio das propostas de autovalorização quando, por exemplo, presenciamos a intenção das Juruna de aprender a fazer o caxiri Yudjá, sendo que o modo de fazer a bebida é lembrado por algumas idosas Juruna da cidade. A despeito desses descompassos, o exemplo também fala do resgate como estabelecimento de uma relação. Pois se os Juruna de Altamira dizem não poder "apresentar aos parentes sua cultura que se perdeu" - modo como uma liderança se expressou em discurso durante o encontro - a ligação, a princípio apenas genealógica e agravada pela distância geográfica, passa ser um elo possível de aliança. Essas possibilidades de conexão

\footnotetext{
${ }^{95}$ Mito de divisão dos grupos Kuruaya e Munduruku apresentado no Capítulo 2.

${ }^{96}$ Pude ter uma grande experiência com os Juruna de Altamira que, no entanto, não são detalhadas na pesquisa, pois demandaria outro esforço etnográfico. Apesar de ser um grupo de mesma importância na cidade - como é lembrado na dissertação - compreende outra história de ligação com esse espaço.
} 
trazem, por exemplo, os dilemas em torno das especulações sobre casamentos - como indicado no Capítulo 3 -, mas trazem, acima de tudo, a experimentação compartilhada que proporciona inflexões capazes de suscitar outras alternativas, como a experiência dos evangélicos Juruna no ritual ayahuasqueiro Yudja ${ }^{97}$ insinua. Trata-se de um campo em aberto, no qual o antropólogo pretendeu contribuir.

A pesquisa em Belo Monte foi uma etnografia sobre transformações. As experiências Xipaya e Kuruaya ora dramáticas e ora criativas são transformações outras, no sentido de que não estão imediatamente alinhadas com nossas noções sobre mudança e relações multiculturais ou interétnicas, como a dissertação tentou argumentar, embora as perspectivas sobre continuidades e misturas apresentadas mantenham influências significativas dessas. Esses espaços de influências permitem traduções e interpretações sobre as quais o antropólogo deve assumir sua específica importância colaborando para que os equívocos possam ser menos desastrosos. Maria Augusta Xipaya, a Xipainha, que como poucas condensa matriarca e liderança numa mesma pessoa, uma vez contou-me sobre como foi a única a defender Belo Monte antes de sua construção, durante o Fórum Social em Belém. Sempre positiva e lutadora a mesma justificou que achava que a barragem seria importante para região, traria trabalho, possibilitaria, em suma, oportunidades aos indígenas e a todos em geral. Depois de algumas conquistas, aos trancos e barrancos, como o bairro do Pedral, e já com um movimento indígena que havia abandonado completamente a luta contra a barragem, a mesma não se furtou em assumir seu arrependimento sobre esse apoio: as promessas não cumpridas eram muito duras para aqueles que lutaram com alguma esperança.

A dissertação foi uma tentativa de expressar essas experiências Xipaya e Kuruaya em transformação nesse cenário crítico de Belo Monte, no qual criação e atuação antropológica pretenderam manter implicação. Analiticamente, optou-se pela discussão sobre história, parentesco e política como forma de problematizar a questão indígena urbana nesses tempos convulsivos. Heuristicamente, fui tentado a compreender algumas possibilidades que valores de memória, família e associativismo têm para os Xipaya e Kuruaya que desejam continuar comendo sua comida, morando em suas casas próximas aos rios onde muitos gostam de pescar, contudo em bairros com acesso à saúde e educação para seus filhos, e sendo reconhecidos como indígenas como qualquer outro que viva nas aldeias. Em suma, querem

\footnotetext{
${ }^{97}$ Curioso indicar que os Yudjá realizam rituais com ayahuasca há pouco mais de dois anos quando esse foi introduzido por praticantes da União do Vegetal. A prática hoje retoma tradições do xamanismo Yudjá segundo os mesmos.
} 
continuar a vida na cidade de Altamira, ou onde quer que ela leve, mantendo costumes e valores que apreciam e sendo respeitados por suas diferenças. As três camadas das experiências indígenas discutidas são um recurso de tradução da relação entre culturas, que refere-se às situações vividas pelas pessoas que participaram da pesquisa, e entre elas e o pesquisador. Esse recurso da etnografia é, no limite, o modo que ela encontrou para que seu interesse participasse com os interesses dos interlocutores, ou seja, pressupondo a possibilidade de troca em diversos níveis, produziram-se formulações compartilhadas e propostas pactuadas na tentativa de responder aos desafios impostos por Belo Monte, essencialmente no campo das políticas culturais. A dissertação pretendeu acompanhar como os interlocutores pensaram os impactos da obra e como essa alterou significativamente a vida de toda região, determinando uma série de encruzilhadas nas quais os indígenas da cidade foram forçados a lutar. Precavendo-se contra a ideia de que a vida dessas pessoas poderia ser reduzida à situação em que se encontram perante Belo Monte, a etnografia optou por retraçar as idas e vindas desses movimentos indígenas que hoje se veem diante de impasses motivados pelo empreendimento que oferece com uma mão e retira com várias outras. Aqui os nós saltam não apenas das incompatibilidades entre políticas indigenistas e indígenas, mas marcam as perversidades de políticas contra-indígenas, revelando abismos cosmopolíticos de difícil resolução como argumenta Carneiro da Cunha (2014:517) sobre propostas de intervenção: “A conclusão é que se deve pisar com cuidado e que, enquanto os números agregados são a via preferencial das políticas, é pela etnografia que elas são testadas".

Concluindo, a dissertação propôs uma etnografia sobre a insistência Xipaya e Kuruaya em continuar vivendo bem, por conseguinte descreveu propostas de resistência, igualmente encorajadas pela vontade de viver melhor. Como resultado esperado, pretendeu experimentar outras possibilidades de diferenças. 


\section{REFERÊNCIAS}

ADALBERTO, Heinrich Wilherlan. (1977). Brasil: Amazonas - Xingu 1811-1873 (pelo) Príncipe Adalberto da Prússia. Belo Horizonte: Itatiaia.

ALBERT, B. “Anthropologie 'apliquée' ou 'impliquée'?” in BARÉ, J.-F. (org.), Les applications de l'Anthropologie, Paris, Harmattan, 1995.

ALBERT, B. \& ALCIDA, R. (Org.). Pacificando o branco: cosmologias do contato no norte-amazônico. São Paulo: Editora UNESP: Imprensa Oficial do Estado, 2002.

. Associações indígenas e desenvolvimento Sustentável na Amazônia Brasileira.

In.: Povos Indígenas do Brasil. Instituto Socioambiental, 1996/2000.

AMOROSO, Marta Rosa. Terra de índio: Imagens em aldeamentos do Império. São Paulo: Terceiro Nome, 2014, vol. 1.

- Etnografia e história da Amazônia, por Peter Gow. Revista Cadernos de Campo, v. 15, n. 14-15. São Paulo, 2006. Disponível em: http://revistas.usp.br/cadernosdecampo/article/view/50106/54226. Acesso em: 15 de Julho de 2014.

ANDRADE, J. A. A. D. De. Experimentos teóricoetnográficos na fronteira entre a etnologia indígena e a antropologia urbana In Ponto Urbe: Revista do Núcleo de Antropologia Urbana, ano 3, versão 4.0, Julho de 2009. Disponível em: http://www.pontourbe.net/edicao7artigos/126experimentosteoricoetnograficosnafronteiraentre aetnologiaindigenaeaantropologiaurbana

ANDRADE, José Agnello Alves Dias de. Indigenização da cidade: etnografia do circuito sateré-mawé em Manaus-AM e arredores. 2012. Dissertação (Mestrado em Antropologia Social) - Faculdade de Filosofia, Letras e Ciências Humanas, Universidade de São Paulo, São Paulo, 2012. Disponível em: <http://www.teses.usp.br/teses/disponiveis/8/8134/tde-05032013-123502/>. Acesso em: 2015-09-27.

ANDRELLO, Geraldo. Cidade do Índio. São Paulo: Editora da UNESP/ISA; Rio de Janeiro: NUTI, 2006.

ARNAULT, Renan. O bairro do Muquiço: história, parentesco e identidades na cidade de Altamira-PA. Projeto de Mestrado apresentado ao Programa de Pós-graduação em Antropologia Social - USP, 2013. 
BARTH, F. Os grupos étnicos e suas fronteiras. In: O guru, o iniciador e outras variações antropológicas. Rio de Janeiro: Contracapa, 2000, pp. 25-67.

CARDOSO DE OLIVEIRA, Roberto. Urbanização e tribalismo. Rio de Janeiro: Jorge Zahar, 1968.

CARNEIRO DA CUNHA, Manuela. "Introdução a uma história indígena". História dos índios no Brasil. São Paulo: Companhia das Letras, 1992.

Cultura com aspas e outros ensaios. São Paulo: Cosac Naif, 2009. 440

pp.

\& CESARINO, Pedro Niermeyer (Org.). Políticas culturais e povos indígenas. São Paulo: Cultura Acadêmica, 2014.

CAVALCANTE, Thiago L. V. Etno-história e história indígena: questões sobre conceitos, métodos e relevância da pesquisa. Revista de História, São Paulo, v.30, n.1, p. 349-371, jan/jun 2011.

COURDREAU, Henri. Viagem ao Xingu-1886. São Paulo: Ed. Universidade, 1977.

CORBISIER, ANA; SERPA, PAULO, 2010. Índios citadinos de Altamira e Famílias Indígenas Ribeirinhas da Volta Grande do Xingu: Aspectos demográficos, Socioeconômicos $\quad$ e $\quad$ Culturais. $\quad$ Disponível em http://www.ecsbarragens.ufpa.br/site/cd/ARQUIVOS/GT3-416-3-20101113190929.pdf, acesso em 03 de Agosto de 2014.

ELETRONORTE. EIA/RIMA AHE Belo Monte Estudo Socioambiental - Componente Indígena citadino e da Volta Grande do Xingu, Brasília, 2009.

FAUSTO, Carlos; HECKENBERGER, Michael. Time and Memory in Indigenous Amazonia: antropological perspectives. University Press of Florida, 2007.

GOLDMAN, Marcio. Lévi-Strauss e os sentidos da História. Rev. Antropologia, São Paulo, v. $42, \quad$ n. $1-2, \quad 1999 . \quad$ Available from <http://www.scielo.br/scielo.php?script=sci_arttext\&pid=S003477011999000100012\&lng=en\&nrm=iso>. access on 21 July 2014. http://dx.doi.org/10.1590/S0034-77011999000100012. 
O fim da antropologia. Novos estudos - CEBRAP. São Paulo , n. 89, p. 195-211, Mar. 2011 $<$ http://www.scielo.br/scielo.php?script=sci_arttext\&pid=S0101$33002011000100012 \& \operatorname{lng}=\mathrm{en} \& \mathrm{nrm}=\mathrm{iso}>$. access on 07 Available from http://dx.doi.org/10.1590/S0101-33002011000100012. Oct. 2015 .

GOW, Peter. 1991. Of Mixed Blood: Kinship and History in Peruvian Amazonia. Oxford Studies in Social and Cultural Anthropology. Oxford: Oxford University Press.

From ethnography to history: "Introduction" and "Conclusion" from Of Mixed Blood: Kinship and History in Peruvian Amazônia. Tradução: Anna Maria de Castro Andradade, Jayne Hunger. Cadernos de campo, São Paulo, n. 14/15, 2006.

.Gringos and wild indians: images of history in western amazonian cultures".

L'Homme, 126-128:327-347, 1993.

O parentesco como consciência humana: o caso dos piro. Mana, Rio de Janeiro, v. 3, n. 2, Oct. 1997 . Available from $<$ http://www.scielo.br/scielo.php?script=sci_arttext\&pid=S010493131997000200002\&lng=en\&nrm=iso>. access on $06 \quad$ Sept. 2012. http://dx.doi.org/10.1590/S0104-93131997000200002.

Canção Purus: nacionalização e tribalização no sudoeste da Amazônia. Rev. Antropologia, São Paulo, v. 49, n. 1, Junho de 2006. Disponível em: <http://www.scielo.br/scielo.php?script=sci_arttext\&pid=S0034-

77012006000100013\&lng=en\&nrm=iso>. Aceso em: 21 Julho de 2014.

HAMBERGER, Klaus. The order of intersubjectivity. Comment on SAHLINS, Marshall. What kinship is - and is not. HAU: Journal of Ethnographic Theory 3 (2): 305-7, 2013.

JUNGHANS, Miriam. Emilia Snethlage (1868-1929): uma naturalista alemã na Amazônia. Hist. cienc. saúde-Manguinhos, Rio de Janeiro , v. 15, supl. p. 243-255, 2008 . Available from <http://www.scielo.br/scielo.php?script=sci_arttext\&pid=S010459702008000500013\&lng=en\&nrm=iso $>$ access on $04 \quad$ Oct. 2015. http://dx.doi.org/10.1590/S0104-59702008000500013.

KELLY, José Antonio. Notas para uma teoria do "virar branco". Mana, Rio de Janeiro, v. 11 n. 1, p. 201-234, Apr. 2005 Available from $<$ http://www.scielo.br/scielo.php?script=sci_arttext\&pid=S010493132005000100007\&lng=en\&nrm=iso >. access on $04 \quad$ Jan. 2016. http://dx.doi.org/10.1590/S0104-93132005000100007. 
LASMAR, Cristiane. De volta ao lago do leite._São Paulo: Editora da UNESP/ISA; Rio de Janeiro: NUTI, 2005.

LÉVI-STRAUSS, Claude. "História e dialética". O Pensamento Selvagem. Campinas-SP: Papirus, 2011.

MAGNANI, José Guilherme Cantor. (1996) Quando o campo é a cidade: fazendo antropologia na metrópole. In: Magnani, José Guilherme C. \& Torres, Lilian de Lucca (Orgs.) Na Metrópole Textos de Antropologia Urbana.EDUSP, São Paulo. Disponível via WWW no URL http://www.nau. org/QUANDOOCAMPOCAPI.pdf.

MAGNANI, José Guilherme. "De perto e de dentro: nota para uma etnografia urbana". In: Revista Brasileira de Ciências Sociais, nº49. São Paulo: ANPOCS, 2002. Disponível em: http://www.scielo.br/scielo.php?pid=S010269092002000200002\&script=sci_arttext.

MICHAELIS. Dicionário de Português Online. Editora Melhoramentos Ltda; UOL. Acesso em: out/2012. Disponível em: http://michaelis.uol.com.br/moderno/portugues/index.php?lingua=portuguesportugues\&palavra $=$ moqui $\% \mathrm{E} 7 \mathrm{o}$

MINISTÉRIO DO MEIO AMBIENTE. Plano de Manejo da Reserva Biológica Nascentes da Serra do Cachimbo. Instituto Chico Mendes de Conservação da Biodiversidade Diretoria de Unidades de Conservação de Proteção Integral Brasília, 2009. Disponível em: http://uc.socioambiental.org/anexos/1649_20140912_165025.pdf. Acesso em setembro de 2015.

MÜLlER, Regina A. Polo. Duas décadas de projetos de desenvolvimento entre povos indígenas: da resistência às frentes de expansão do capitalismo nacional à globalização e ambientalismo dos anos 90. In.: Revista de Estudos e Pesquisas, FUNAI, Brasília, v.1, n.1, p.181-203, jul. 2004.

NIMUENDAJÚ, Curt. Tribes of the Lower and Middle Xingu River. In: Handbook of South American Indians. Vol.3. Washington DC: ed. Julian H. Steward, 1948.

Fragmentos de Religião e tradição dos Sipáia. In: Religião e Sociedade 7. São Paulo: Cortez, 1981.

Textos Indigenistas: relatórios, monografias e cartas. Coleção Aberta, nº 6, São

Paulo: Loyola. 1982. 
NORTE ENERGIA. Relatório de cadastramento das famílias indígenas realocadas. Polifônicas Ideais, Altamira, 2012.

NUNES, Eduardo Soares. Aldeias urbanas ou cidades indígenas? Reflexões sobre índios e cidades. Espaço Ameríndio, Porto Alegre, v. , n. 1, p. 9-30, jan./jun. 2010.

. A cruz e o itxe(k)ò: mestiçagem, mistura e relação entre os Karajá de Buridina (Aruanã - GO). Versão resumida de um dos capítulos de minha monografia de graduação (Nunes, 2009). In.: Associação Brasileira de Antropologia ABA. Premio Claude Lévi-Strauss, Brasília, 2009.

OLIVEIRA, João Pacheco de. Uma etnologia dos "índios misturados"? Situação colonial, territorialização e fluxos culturais. Mana, Rio de Janeiro, v. 4, n. 1, Apr. 1998 . Disponível em: <http://www.scielo.br/scielo.php?script=sci_arttext\&pid=S010493131998000100003\&lng=en\&nrm=iso $>$ access on $06 \quad$ Sept. 2012. http://dx.doi.org/10.1590/S0104-93131998000100003.

PATRÍCIO, Marlinda Melo Patrício. "Índios de verdade?" O caso dos Xipaia e Kuruaia em Altamira. Dissertação (Mestrado em Antropologia Social) Departamento de Antropologia, UFPA, Belém -PA, agosto de 2000.

SAHLINS, M. Metáforas históricas e realidades míticas. Rio de Janeiro: Jorge Zahar, 2008.

. O "pessimismo sentimental" e a experiência etnográfica: por que a cultura não é um "objeto" em via de extinção (parte I). Mana, Rio de Janeiro, v. 3, n. 1, Apr. 1997. Available from $\quad<$ http://www.scielo.br/scielo.php?script=sci_arttext\&pid=S010493131997000100002\&lng=en\&nrm=iso>. access on $30 \quad$ July 2014. http://dx.doi.org/10.1590/S0104-93131997000100002.

Institute, Londres, 2011.

What kinship is (part one). In.: Journal of the Royal Anthropological

SARAIVA, Márcia Pires. Identidade Multifacetada: a reconstrução do ser indígena entre os indígenas do médio-Xingu. Dissertação de mestrado. UFPA, Núcleo de Altos Estudos Amazônicos. Curso Internacional de Mestrado em Planejamento e Desenvolvimento, Belém, 2005.

SIMONI, Alessandra T. \& DAGNINO, Ricardo S. População indígena e Território na Amazônia brasileira: estudo de caso da população Xipaya no município de Altamira, Pará. In.: V Congreso de la Asociación Latinoamericana de Población, Montevideo, Uruguay, del 23 al 26 de octubre de 2012. 
SILVA, Marcio. Organizações Indígenas na Amazônia Brasileira: um rápido sobrevôo », Ponto Urbe [Online], 7 | 2010, posto online no dia 31 Dezembro 2010, consultado o 27 Setembro 2015. URL : http://pontourbe.revues.org/1650

Uma análise da população indígena na cidade de Altamira, Estado do Pará, com base nos dados do Censo 2010. In.: XVIII Encontro Nacional de Estudos Populacionais, ABEP, realizado em Águas de Lindóia/SP - Brasil, de 19 a 23 de novembro de 2012.

SCHWARCZ, Lilia K. Moritz. Questões de fronteira: sobre uma antropologia da história. Novos estudos - CEBRAP, São Paulo, n. 72, July 2005 . Available from <http://www.scielo.br/scielo.php?script=sci_arttext\&pid=S010133002005000200007\&lng=en\&nrm=iso>. access on 26 Apr. 2013. http://dx.doi.org/10.1590/S0101-33002005000200007.

SNETHLAGE, Emilia. A Travessia entre o Xingu e o Tapajós. Boletim do Museu Goeldi. Vol. VII. Belém, 1910.

- Catálogo das aves amazônicas, contendo todas as espécies descriptas e mencionadas até 1913. Boletim do Museu Paraense de História Natural e Ethnographia, Belém, v.8, p.1-530. 1914.

SEVÁ FILHO, A. Tenotã Mõ: Alertas sobre as consequências dos projetos de hidrelétricas no Rio Xingu. São Paulo: IRN - International Rivers Network, 2005. Arquivo em www.fem.unicamp.br/ seva.

SILVA, Marcio. Organizações Indígenas na Amazônia Brasileira: um rápido sobrevoo. Ponto Urbe [Online], 7 | 2010, posto online no dia 31 Dezembro 2010, consultado o 17 Setembro 2015. URL : http://pontourbe.revues.org/1650 ; DOI : 10.4000/pontourbe.1650

STEIN, Karl Von Den. O Brasil Central: expedição em 1884 para a exploração do Rio Xingu. Companhia Editora Nacional, 1942.

SZRTUTMAN, Renato. De outros caxiris: festa, embriaguez e comunicação na Amazônia indígena. Versão para publicação - Outubro de 2006 - de Dissertação de Mestrado defendida em 2001 no PPGAS da USP.

UMBUZEIRO, Ubirajara Marques. Altamira e sua História. $2^{\text {a }}$ ed. Ver. Aum. Altamira, 1990: Grucalt/ Sopocaba.

VIVEIROS DE CASTRO, Eduardo. O nativo relativo. Mana, Rio de Janeiro, v. 8, n. 1, Apr. 2002.Disponível em: <http://www.scielo.br/scielo.php?script=sci_arttext\&pid=S0104- 
93132002000100005\&lng=en\&nrm=iso>. access on
http://dx.doi.org/10.1590/S0104-93132002000100005.

05

Sept.

2012.

No Brasil, todo mundo é índio, exceto quem não é. Instituto Socioambiental, 2006 Disponível em:

http://pib.socioambiental.org/files/file/PIB institucional/No_Brasil_todo_mundo_\%C3\%A9 \%C3\%ADndio.pdf.

. "Etnologia brasileira", em: Miceli, Sérgio (org.). O que ler na ciência social brasileira (1970-1995), v.1, Antropologia. São Paulo: Sumaré/ANPOCS; Brasília: CAPES, 1999.

WAGNER. Roy. A invenção da cultura. Trad. Marcela Coelho de Souza e Alexandre Morales. São Paulo: Cosac Naify, 2010.

WOORTMANN, Klaas. O selvagem e a História. Heródoto e a questão do Outro. Rev. Antropologia, São Paulo, v. 43, n. 1, 2000.
<http://www.scielo.br/scielo.php?script=sci arttext\&pid=S0034$77012000000100002 \& \operatorname{lng}=\mathrm{en} \& \mathrm{nrm}=\mathrm{iso}>$. access on 21 Available from http://dx.doi.org/10.1590/S0034-77012000000100002. 